\title{
SAÚDE E NUTRIÇÃO DE CRIANÇAS INDÍGENAS TERENA, MATO GROSSO DO SUL, BRASIL
}

DULCE LOPES BARBOZA RIBAS

Tese de doutorado apresentada ao Departamento de Nutrição da Faculdade de Saúde Pública da Universidade de São Paulo para obtenção do Grau de Doutor.

Área de concentração: Nutrição

ORIENTADORA:

PROF ${ }^{a}$ DRA. SONIA TUCUNDUVA PHILIPPI

CO-ORIENTADOR:

PROF $^{\circ}$ DR. JOSE ROBERTO ZORZATTO

SÃO PAULO

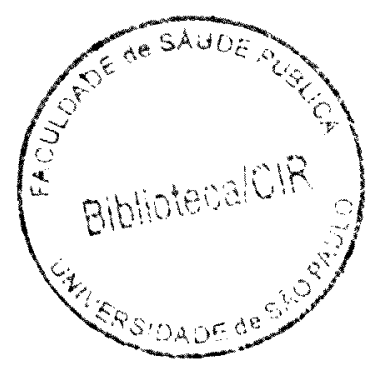




\section{SAÚDE E NUTRIÇÃO \\ DE CRIANÇAS INDÍGENAS TERENA, \\ MATO GROSSO DO SUL, BRASIL}

DULCE LOPES BARBOZA RIBAS

Tese de doutorado apresentada ao Departamento de Nutrição da Faculdade de Saúde Pública da Universidade de São Paulo para obtenção do Grau de Doutor.

Área de concentração: Nutrição

ORIENTADORA:

PROF $^{\mathrm{a}}$ DRA. SONIA TUCUNDUVA PHILIPPI

CO-ORIENTADOR:

PROF $^{\circ}$ DR. JOSE ROBERTO ZORZATTO

SÃO PAULO

2001 


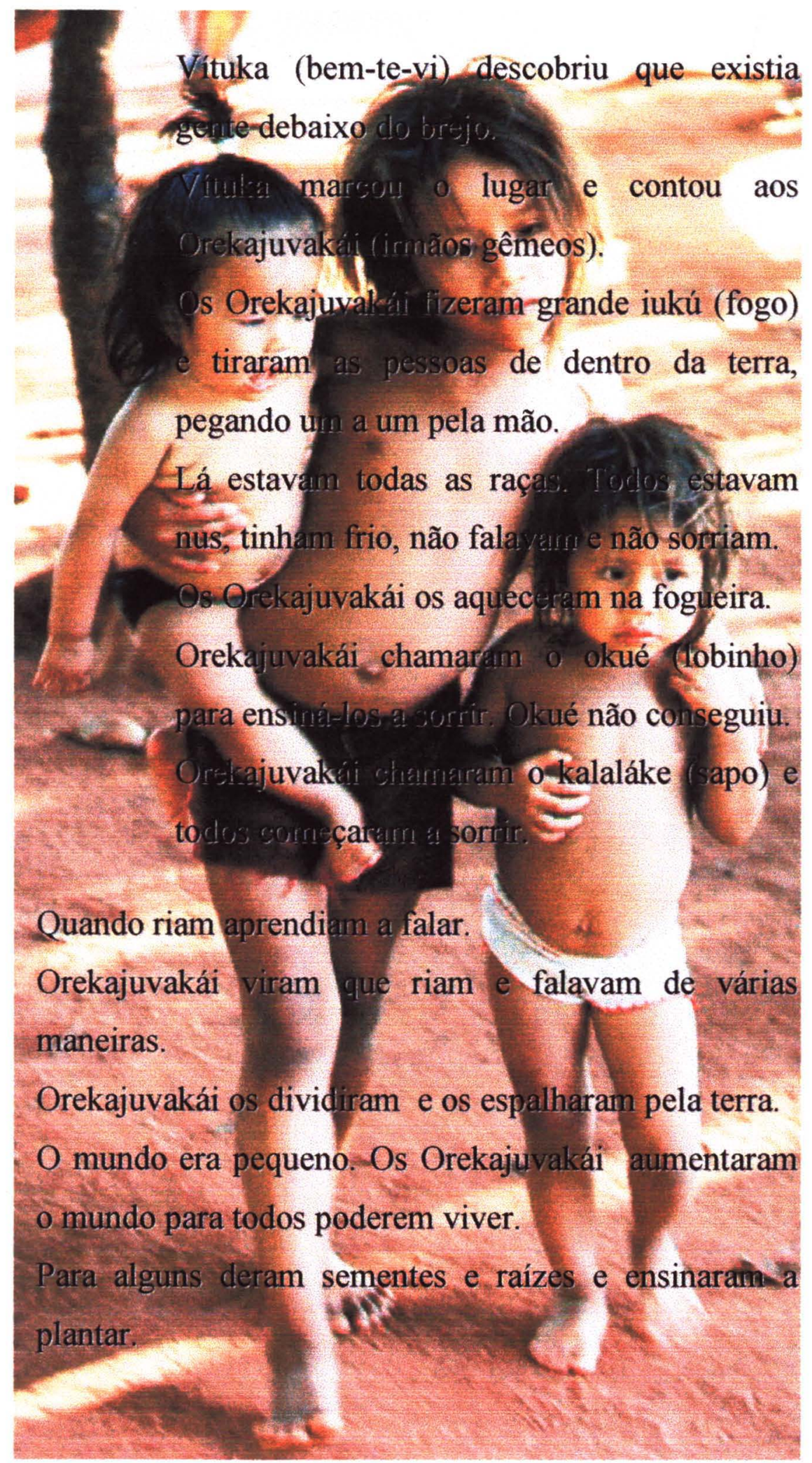




\section{DEDICATÓRIA}

À memória de

Jari Barboza 


\section{AGRADECIMENTOS}

Desejo exprimir toda a minha gratidão a Deus que me encaminhou para o território Terena.

Aos Terena que me acolheram com carinho e compreensão.

Aos meus familiares que estiveram sempre ao meu lado, em especial ao Ribas, Marina e Délia.

Aos meus orientadores: Dra. Sonia Philippi e

Dr. Zorzatto, exemplos de capacidade e disponibilidade.

Aos professores: Dra. Dominique Buchillet, Dr. Carlos Coimbra, Dr. Arnaldo Siqueira, Dra. Aracy Spínola, Dra. Mariana Ferreira e Dra. Maria de Fátima Marucci pelas valiosas contribuições.

Aos amigos e colaboradores: Alfredo que me ensinou a ouvir o silêncio dos Terena. Sérgio, Silvio e Antonio por demonstrarem que a vida é simples e bela.

Marly, Dejair, Cláudia, Delurma, Eliane, Léia, Jael, Dionísio, Marcio, Sandra, Rita, Silvia, Mariane, Marcia, Rosa, Neusa, Euclides e Ademar pelas inúmeras colaborações e o alegre convívio.

À Universidade Federal de Mato Grosso do Sul, especialmente ao Departamento de Tecnologia de Alimentos e Saúde Pública pela liberação e irrestrito apoio.

À CAPES (Coordenação de Aperfeiçoamento de Pessoal de Nível Superior) pela bolsa de estudo concedida.

Ao FUNDECT (Fundação de Apoio ao Desenvolvimento do Ensino, Ciência e Tecnologia do Estado de Mato Grosso do Sul) pelo financiamento para o desenvolvimento do projeto. 


\section{ÍNDICE}

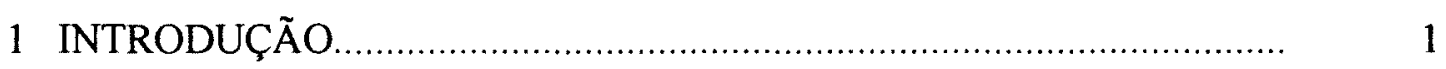

2 OS TERENA: TERRA E GENTE ...........................................................

2.1 Território Indígena

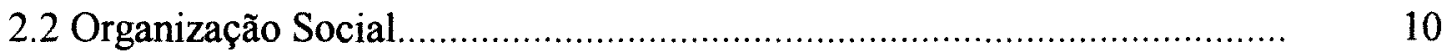

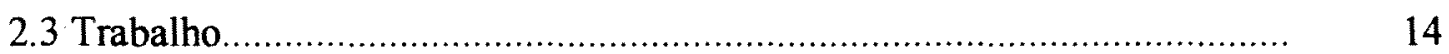

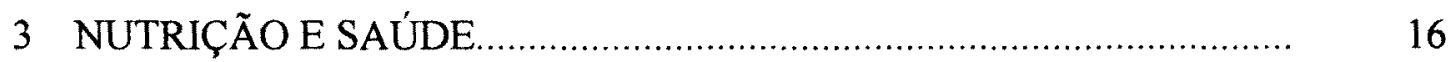

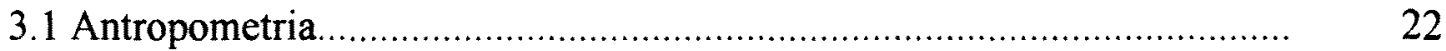

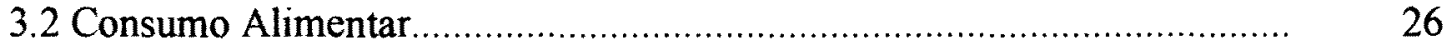

3.3 Programas Assistenciais.................................................................... 28

3.4 Assistência à Saúde Indígena ..................................................................

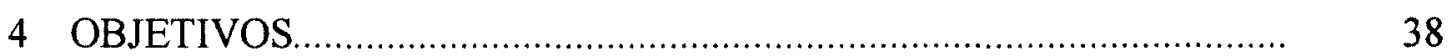

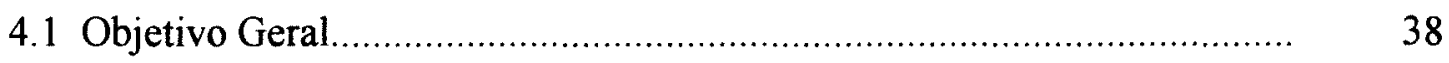

4.2 Objetivos Específicos........................................................................... 38

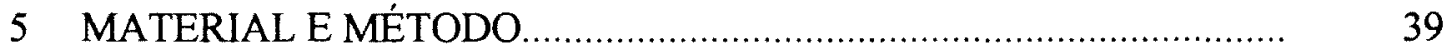

5.1 População do Estudo .............................................................................. 40

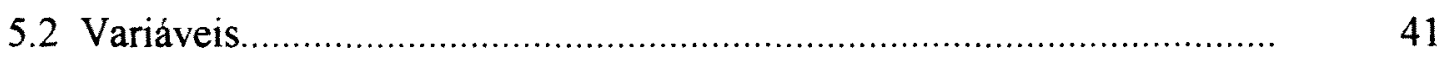

5.2.1 Socioeconômicas, Demográficas e Ambientais .................................... 41

5.2.2 Variáveis Antropométricas................................................................

5.2.3 Assistência à Saúde Materno-Infantil..................................................... 43

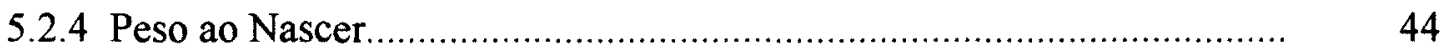

5.2.5 Morbidade e Internações Hospitalares.................................................. 44

5.2.6 Consumo Alimentar............................................................................. 44

5.2.7 Aleitamento Materno .......................................................................... 46

5.3 Coleta de Dados................................................................................. 47

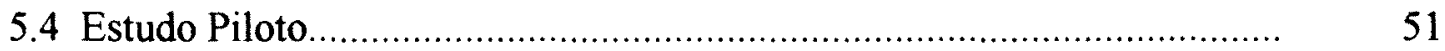

5.5 Processamento e Análise dos Dados...................................................... 51

5.6 Aspectos Éticos ............................................................................... 52

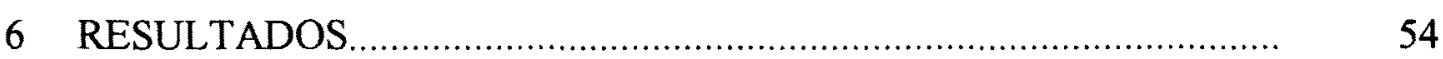

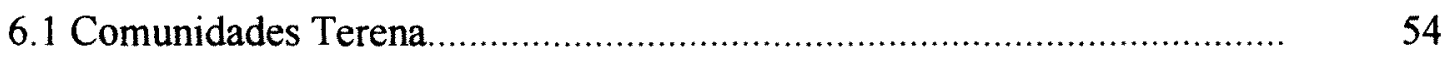


6.1.1 Características Socioeconômicas................................................. 54

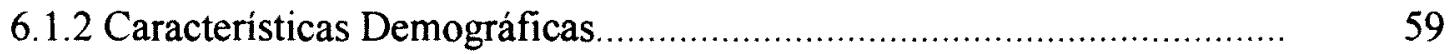

6.1.3 Caracteristicas Ambientais................................................................ $\quad 60$

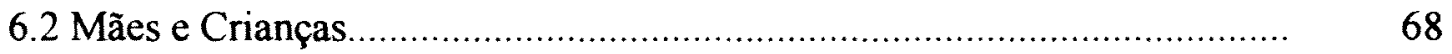

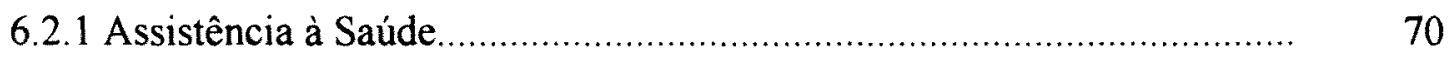

6.2.2 Morbidade e Internações Hospitalares.............................................. 78

6.2.3 Alimentação Infantil............................................................. $\quad 80$

6.2.4 Aleitamento Materno ...................................................................... $\quad 88$

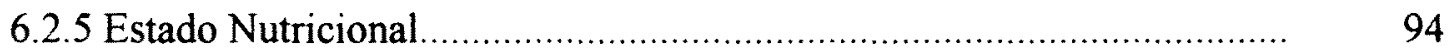

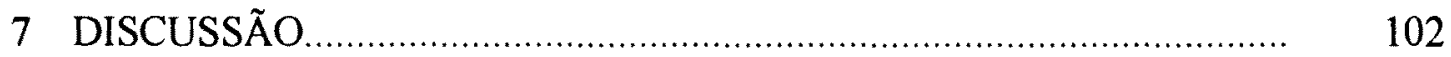

7.1 Aspectos Metodológicos...................................................................... 102

7.2 Desafios à Vida Terena........................................................... 103

7.2.1 Condições Socioeconômicas e Ambientais.......................................... 103

7.2.2 Assistência à Saúde............................................................................ 107

7.2 .3 Nutrição.......................................................................... 114

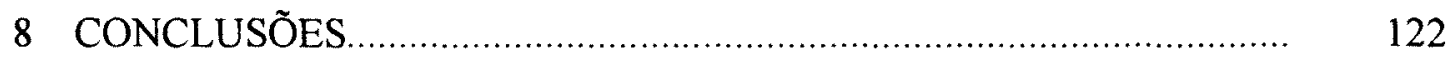

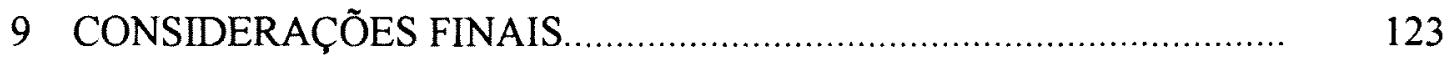

10 REFERÊNCIAS ....................................................................... 124 ANEXOS

Anexo 1 - Termo de Aprovação no Comitê de Ética da FSP/USP

Anexo 2 - Termo de Aprovação no Comitê Nacional de Ética Anexo 3 - Autorização de Ingresso em Terra Indígena Ano 1999

Anexo 4 - Autorização de Ingresso em Terra Indígena Ano 2000

Anexo 5 - Termo de Consentimento

Anexo 6 - Questionário de Coleta de Dados

Anexo 7 - Áreas Indígenas Terena no Estado de Mato Grosso do Sul Anexo 8 - Retratos Terena 


\section{LISTA DE TABELAS}

Tabela 1. Distribuição das famílias indígenas segundo a localização dos domicílios e renda familiar per capita

Tabela 2. Distribuição das famílias indígenas segundo a escolaridade dos pais e ocupações do chefe de família.

Tabela 3. Distribuição das características demográficas de famílias Terena

Tabela 4. Distribuição das características ambientais dos domicílios.

Tabela 5. Distribuição das características de construção e equipamentos dos domicílios.

Tabela 6. Distribuição das crianças segundo local de moradia, sexo e idade.

Tabela 7. Distribuição das características da assistência pré-natal.

Tabela 8. Distribuição das características das condições de nascimento.

Tabela 9. Distribuição das ações básicas do programa de atenção integral à saúde da criança.

Tabela 10. Distribuição proporcional de enfermidades em crianças indígenas Terena.

Tabela 11. Distribuição da média de consumo de energia e nutrientes

Tabela 12. Distribuição de freqüência da prática de aleitamento materno segundo a faixa etária.

Tabela 13.Distribuição da prevalência de déficits nutricionais segundo sexo

Tabela 14. Prevalência de déficits de estatura/idade e peso/estatura segundo características das crianças indígenas.

Tabela 15. Prevalência de déficits estatura/idade e peso/estatura segundo características socioeconômicas de famílias indígenas. 


\section{LISTA DE FIGURAS}

Figura 1. Localização do Estado de Mato Grosso do Sul

Figura 2. Estado de Mato Grosso do Sul com localização dos municípios de Dois Irmãos do Buriti e Sidrolândia.

Figura 3. Placa de identificação na rodovia MS 162.

Figura 4. Fluxograma descritivo da população do estudo.

Figura 5. Habitação Terena..

Figura 6. Obtenção da circunferência braquial.

Figura 7. Criança recebendo a primeira refeição do dia......

Figura 8. A alegria de amamentar.

Figura 9. Avó apresenta seu neto...

Figura 10. Realização de uma entrevista.

Figura 11. Preparação para a pesagem.

Figura 12. Apresentação de resultados à família.

Figura 13. Entrevistador tem o privilégio do encontro e do diálogo.

Figura 14. Distribuição percentual da renda familiar per capita.

Figura 15. Distribuição percentual da escolaridade materna...

Figura 16. Distribuição percentual da escolaridade paterna.

Figura 17. Distribuição percentual do abastecimento de água.

Figura 18. Meninos brincam no rio.

Figura 19. Instalações sanitárias.

Figura 20. Distribuição percentual do escoamento de dejetos.

Figura 21. Distribuição percentual do destino do lixo..

Figura 22. Distribuição percentual de energia elétrica dos domicílios......... 65

Figura 23. Distribuição percentual do material de construção das paredes..... $\quad 66$

Figura 24. Distribuição percentual do material de cobertura....................... 67

Figura 25. Distribuição percentual das características do piso..................... 67

Figura 26. Brincadeiras infantis revelam as dificuldades da vida Terena...... $\quad 69$

Figura 27. Distribuição percentual da assistência pré-natal......................... 72 
Figura 28. Distribuição percentual da assistência pré-natal segundo escolaridade materna.

Figura 29. Distribuição percentual da assistência pré-natal segundo a renda per capita familiar 73

Figura 30. Distribuição percentual do local de realização do parto... 75

Figura 31. Distribuição percentual do tipo de parto 75

Figura 32. Distribuição percentual do baixo peso ao nascer de crianças indígenas.

Figura 33. Distribuição percentual da vigilância do crescimento das crianças menores de cinco anos

Figura 34. Distribuição percentual da cobertura vacinal em crianças indígenas.

Figura 35. Distribuição percentual das enfermidades em crianças indígenas

Figura 36. Distribuição comparativa do consumo de energia da dieta infantil e as recomendações da $10^{\mathrm{a}} \mathrm{RDA}$

Figura 37. Distribuição comparativa do consumo de proteína e as recomendações da $10^{\mathrm{a}} \mathrm{RDA}$

Figura 38. Distribuição comparativa do consumo de vitamina $\mathrm{A}$ e as recomendações da $10^{\mathrm{a}} \mathrm{RDA}$

Figura 39. Distribuição comparativa do consumo de vitamina $\mathrm{C}$ e as recomendações da $10^{\mathrm{a}} \mathrm{RDA}$

Figura 40. Distribuição comparativa do consumo de ferro e as recomendações da $10^{\mathrm{a}} \mathrm{RDA}$

Figura 41. Distribuição comparativa do consumo de cálcio da dieta infantil e as recomendações da ingestões dietética de referência.

Figura 42. Distribuição percentual do aleitamento materno.

Figura 43. Distribuição percentual de crianças indígenas desmamadas.

Figura 44. Distribuição percentual da prática de incentivo ao aleitamento materno.

Figura 45. Distribuição percentual de aleitamento materno segundo a idade na Aldeia Tereré. 
Figura 46. Distribuição percentual de aleitamento materno segundo idade na Aldeia Buriti.

Figura 47. Distribuição percentual de aleitamento materno segundo idade na Aldeia Córrego do Meio..

Figura 48. Distribuição percentual de aleitamento materno segundo idade na Aldeia Água Azul.

Figura 49. Distribuição percentual do índice peso/idade nas crianças indígenas menores de cinco anos e distribuição de referência NCHS.

Figura 50. Distribuição percentual do índice estatura/idade nas crianças indígenas menores de cinco anos e distribuição de referência NCHS

Figura 51. Distribuição percentual do índice peso/estatura nas crianças indígenas menores de cinco anos e distribuição de referência NCHS.

Figura 52. Distribuição comparativa entre a referência NHANES e média da circunferência braquial por grupo etário de crianças indígenas com e sem déficit de estatura/idade.

Figura 53. Distribuição comparativa entre a referência NCHS e média de peso por grupo etário de crianças indígenas com e sem déficit de estatura/idade.

Figura 54. Distribuição comparativa entre a referência NCHS e média de estatura por grupo etário de crianças indígenas com e sem déficit de estatura/idade. 


\section{LISTA DE SIGLAS}

CIMI - Conselho Indigenista Missionário

CISI - Comissão Intersetorial de Saúde do Índio

CNS - Conferência Nacional de Saúde

CNSPI - Conferência Nacional de Saúde de Populações Indígenas

DRI - Dietary Reference Intakes

DSEI - Distritos Sanitários Especiais Indígenas

ENDEF - Estudo Nacional de Despesa Familiar

FIBGE - Fundação Instituto Brasileiro de Geografia e Estatística

FUNASA - Fundação Nacional de Saúde

FUNAI - Fundação Nacional do Índio

ICNND - Interdepartamental Committee on Nutrition for National Defense

INAN - Instituto Nacional de Alimentação e Nutrição

NAS - National Academy of Sciences

NHANES - National Health and Nutrition Examination Survey

NCHS - National Center for Health Statistics

OMS - Organização Mundial de Saúde

ONU - Organização da Nações Unidas

OPAS - Organização Panamericana de Saúde

PAISM - Programa de Assistência Integral à Saúde da Mulher

PNIAM - Programa Nacional de Incentivo ao Aleitamento Materno

PNSN - Pesquisa Nacional em Saúde e Nutrição

RDA - Recommended Dietary Allowances

SPI - Serviço de Proteção ao Índio

SUS - Sistema Único de Saúde

SUSA - Serviço de Unidades Sanitárias Aéreas

UNICEF - Fundo das Nações Unidas para Infância

WHO - World Health Organization 


\section{RESUMO}

Ribas DLB. Saúde e nutrição de crianças indígenas Terena, MS, Brasil. São Paulo; 2001. [Tese de Doutorado - Faculdade de Saúde Pública. Universidade de São Paulo].

Objetivo. Ampliar as possibilidades de observação e construção de indicadores sociais e biológicos de grupos indígenas é uma necessidade urgente. Neste sentido, realizou-se estudo com objetivo de avaliar as condições de saúde e nutrição de crianças indígenas, com a descrição das condições socioeconômicas, demográficas e ambientais. Métodos. A amostra do estudo constituiu-se de 354 crianças de zero a cinqüenta e nove meses de idade. Foram obtidas medidas de peso, estatura e circunferência braquial, para avaliação nutricional. O método recordatório de $24 \mathrm{~h}$ foi utilizado para a avaliação do consumo alimentar. Resultados. As condições socioeconômicas e ambientais eram precárias, com diferenças significativas na distribuição, segundo a localização dos domicílios. Os dados indicaram precariedade dos serviços de assistência à saúde materno-infantil. As famílias que receberam os beneficios são principalmente aquelas que possuem maior facilidade de acesso e não às submetidas a maiores riscos. A diarréia e as infecções respiratórias foram as principais causas das internações hospitalares. A amamentação é prolongada, com elevada freqüência e forte componente cultural agindo favoravelmente. O consumo alimentar foi caracterizado pela monotonia da dieta, com aporte insuficiente de energia e nutrientes. Os déficits nutricionais verificados são baixos quando comparados com prevalências de comunidades indígenas da região amazônica, mas superiores às prevalências de déficits de estatura/idade da população brasileira como um todo. Conclusões. Os resultados indicam déficits nutricionais nas crianças indígenas, como reflexo direto da pobreza a que estão submetidas, incluindo condições ambientais e socioeconômicas desfavoráveis e deficiência alimentar continuada.

Descritores: Avaliação nutricional. Saúde infantil. Consumo de alimentos. Índios sul-americanos. 


\section{SUMMARY}

RIBAS DLB. Health and nutrition among Terena indigenous children, MS, Brazil. São Paulo; 2001. [Doctor's degree thesis - Faculdade de Saúde Pública. Universidade de São Paulo].

Purpose: Increasing the opportunities to examine and develop social and biological indicators for indigenous populations is currently a pressing need. In order to meet this demand, the present study was carried out for assessing the health and nutrition status of Terena indigenous children, including the description of the socioeconomic, demographic and environmental conditions. Methods: The study sample was composed of 354 children from 0 to 59 months of age, correponding to $98,9 \%$ of the population younger than five. Weight, height and arm circunference were measured for the nutritional assessment. The twenty-four-hour food recall was used to avaliate the food intake and diet composition in macro and micronutrients. Results: Socioeconomic and environmental conditions were precarious, with significant differences depending on the location of the households. Data has revealed a low level of utilization of maternal-infant health care services. Families receiving these benefits where mainly those with easier access to them and not the ones subjected to higher risks. Diarrhea and respiratory infections were the leading causes of hospital admissions. Breastfeeding was highly frequent, it is an strong cultural component that acts favourably. Food intake was characterized by the monotony of the diet, with insufficient energy and nutrient inputs. The observed nutritional deficits are lower than the Brazilian population as a whole. Conclusions: Results revealed the presence of nutritional deficits in indigenous children, which are a direct result of poverty compouded by unfavorable environmental, and socioeconomic conditions, and by continual dietary deficiencies.

Keyword: Nutritional assessment. Infant health. Food consumption. South American Indians. 


\section{INTRODUÇÃO}

Estudos em sociedades indígenas são marcantes no campo da antropologia, especialmente de etnografia, cuja tradição de pesquisa nessas comunidades é longa e frutifera. No entanto, a pouca atenção à pesquisa na área de saúde e nutrição revela a necessidade de ampliar as investigações na área indígena, revertendo o quadro de desconhecimento e aprofundando as reflexões sobre esse grupo populacional.

De acordo com COIMBRA JÚNIOR (1985), é grave a situação que hoje enfrentam as populações indígenas no Brasil. Alcoolismo, desnutrição, tuberculose, anemia, prostituição e destruição ambiental estão entre as tantas agressões, amplamente divulgadas (COIMBRA JÚNIOR 1985).

Ampliar as possibilidades de observação e construção de indicadores sociais e biológicos de grupos indígenas são medidas necessárias e que podem ser desenvolvidas por instituições de ensino e pesquisa próximas de áreas indígenas, favorecendo o convívio, o compromisso com problemas e as características das regiões.

Apesar de reconhecida importância em termos de saúde coletiva, ainda são poucos os trabalhos que incluem informações sobre o estado nutricional de populações indígenas brasileiras.

Para as populações indígenas, o rápido e abrupto contato com outra sociedade, assim como suas repercussões socioeconômicas estão associadas a processos destrutivos nas várias dimensões de sua organização social. Dentre as conseqüências imediatas do contato, estão a alteração de indicadores demográficos e o comprometimento das atividades de subsistência (COIMBRA JÚNIOR 1985).

Com a mudança das atividades básicas de subsistência ocorre redução na disponibilidade e variabilidade alimentar com maior dependência de produtos industrializados, podendo ocorrer alterações nutricionais, tais como, hipovitaminoses, anemia e desnutrição, especialmente em crianças, devido à alta vulnerabilidade.

Do ponto de vista sanitário, o crescimento populacional e a redução da mobilidade, levam a uma crescente contaminação do ambiente por formas de 
infectantes, parasitas intestinais e entero bactérias, devido ao acúmulo progressivo de dejetos em torno das aldeias. Tais condições favorecem a transmissão de doenças veiculadas pela água, como as gastroenterites (COIMBRA JÚNIOR 1987).

A presença de parasitas intestinais representa um fator agravante da desnutrição, seja pela diarréia crônica, seja pela competição pelo alimento ingerido (GUPTA 1980).

Estudos revelam que episódios freqüentes de infeç̧ões, principalmente diarréia e doenças respiratórias, influenciam o crescimento infantil levando à perda aguda de peso e retardando o crescimento linear (BLACK et al., 1984; NABARRO et al., 1988; BITTENCOURT et al., 1993). A presença de doenças em aldeias Terena impõem a difícil busca de assistência, evidenciando o acesso desigual a bens e serviços essenciais.

Atualmente os Terena vivem em áreas insuficientes para a prática da agricultura tradicional, em terras com sinais de desgastes e esgotamento de recursos naturais, o que inviabiliza a economia de subsistência, além da reduzida assistência do governo federal, representada pelos poucos recursos destinados ao desenvolvimento de projetos em comunidades indígenas e problemas administrativos no órgão indigenista oficial (FUNAI), levando os membros das comunidades, sobretudo os homens, a buscarem trabalho remunerado em fazendas, usinas e municípios vizinhos, muitas vezes com remunerações irrisórias que impossibilitam o sustento da família.

Uma análise das condições de saúde e nutrição de crianças indígenas tem maior valor intrínseco, ao conseguir auxiliar setores políticos locais e órgãos responsáveis pela saúde dessas comunidades, com vistas a aperfeiçoar e diversificar os recursos existentes em favor dos grupos mais vulneráveis, que demandam atenção especial de profissionais preparados para ações preventivas e assistenciais nas aldeias.

O acompanhamento das condições nutricionais das crianças de um país constitui instrumento essencial para aferição das condições de saúde da população infantil e oportunidade ímpar para se obterem medidas objetivas da evolução das condições de vida da população em geral (MANSON et al., 1984). A inferência sobre as condições gerais de vida advém da origem multicausal da desnutrição e da íntima relação que a nutrição infantil mantém com o grau de atendimento de 
necessidades básicas como a alimentação, moradia, saneamento, assistência à saúde e educação (MONTEIRO et al. 2000a).

A Organização Mundial da Saúde (OMS) recomenda o uso de medidas antropométricas para avaliação do estado nutricional infantil nos estudos epidemiológicos nutricionais de populações, como recurso para investigar variações nas dimensões físicas e na composição geral do corpo humano, a partir de medições individuais, cuja somatória possibilita uma avaliação do estado nutricional em nível coletivo (WATERLOW et al., 1977; OMS 1983).

A diversidade de características, hábitos e costumes existentes entre os grupos, assim como o tempo e o histórico do contato interétnico, dificultam a extrapolação de resultados isolados para o conjunto das populações indígenas do país.

Fica cada vez mais evidente a necessidade de se proceder estudos situando a avaliação nutricional como uma forma de medir o papel exercido pelos fatores ambientais cristalizados nas condições de vida, saúde e alimentação de populações indígenas, uma vez que o estado nutricional é um elemento fundamental do processo saúde-doença, onde inadequações como déficits nutricionais e carência de nutrientes guardam estreita relação com a ocorrência ou agravamento de doenças e o setor saúde tem o papel de dar resposta aos agravos sofridos pela população.

Ainda que o estudo de populações indígenas brasileiras possa ter avançado nos últimos anos, face à importância do tema, há necessidade de pesquisas junto aos diversos grupos indígenas do país, que possibilitem o conhecimento de aspectos mais aprofundados, como compreensão das inter-relações entre condições socioeconômicas e estado nutricional, justificando-se em nivel de conhecimento e contribuição social.

A eleição de duas áreas indígenas Terena para a realização da pesquisa, deu-se inicialmente pelo fato de participar de um grupo de estudos, com pesquisadores que já desenvolviam trabalhos nessas áreas. Num segundo momento, pelo envolvimento pessoal oriundo do contato com famílias Terena, onde é impossível permanecer indiferente às peculiaridades do viver, além da aceitação e acolhimento do projeto por parte de lideranças locais.

A escolha do tema partiu do interesse em conhecer este modo de vida, investigando as condições de saúde e nutrição infantil e as possíveis associações dessas condições com variáveis socioeconômicas, demográficas e ambientais de 
famílias submetidas a um longo contato com a sociedade envolvente, com a qual mantêm estreita relação social e econômica.

Acredita-se que este estudo produziu informações que evidenciam parte da realidade social, considerando o caráter dinâmico com que o perfil de saúde se transforma, oferecendo subsídios à consolidação de propostas destinadas à melhoria da vida do povo Terena. 


\section{OS TERENA: TERRA E GENTE}

A população estudada pertence ao subgrupo Guaná-Txané, remanescentes da família Aruak. Há várias indicações sobre a origem deste povo, neste estudo foi adotada a indicação como originários do Chaco paraguaio. Dados sobre a migração inicial dos Terena para o sul de Mato Grosso apontam o ano de 1649, quando os Mbayá-Guaykurú tornaram-se dominadores do território pantaneiro, submetendo outras nações indígenas, dentre elas a nação Guaná (OBERG 1949).

Os primeiros contatos dos Terena com as culturas européias ocorreram provavelmente com as primeiras viagens espanholas e portuguesas que buscavam, através do Chaco, um caminho para o império peruano (OBERG 1949).

As aldeias eram situadas em áreas de planície, próximas de rios, cada uma delas com aproximadamente vinte casas longas, de teto arqueado e com mobiliário rudimentar, a maioria contendo várias famílias, obedecendo a um chefe e distribuídas ao redor de uma praça central (OBERG 1949; SILVA 1949).

Castelnau (1850), citado por SILVA (1949, p. 279) descreve visita a uma aldeia Terena, próxima do Município de Miranda, com 110 casas unidas umas às outras, dispostas em círculo ao redor de uma grande praça. Frei Mariano de Bagnaia (1850), citado por SGANZERLA (1992, p.182), foi designado à catequese dos índios na região de Miranda e assim descreve seu primeiro encontro com os índios: "Entrei neste deserto, num vale belíssimo; encontrei três tribos de índios: Quiniquinaos, Guanás e Terena. Aos chefes expliquei o motivo de minha vinda. Logo todos se ergueram de pé e me acolheram amigavelmente".

Agricultores, com áreas cultivadas ao redor da aldeia, plantavam mandioca, abóbora, batata-doce, pimenta, milho e feijões, onde a terra não gerava renda, basicamente servia para instalar moradias e produzir alimentos de subsistência. A unidade econômica era a família extensa, com atividades de plantio de roças, coleta de raízes e frutos silvestres, combinadas com a caça e a pesca (OBERG 1949).

A divisão do trabalho reservava ao homem a caça, a pesca, o plantio e as atividades guerreiras, deixando à mulher o preparo dos alimentos, a coleta de frutos e raízes silvestres, a cerâmica e a fiação (SILVA 1949). Embora possuíssem o algodão 
e conhecessem a técnica de tecer, não usavam redes, que só passaram a utilizar anos mais tarde.

De acordo com Silva (1949), o fogo era produzido pela fricção de duas varetas e a maioria dos alimentos eram consumidos cozidos, atualmente utilizam o fogão a gás e o de lenha, havendo predomínio da utilização de frituras no preparo dos alimentos.

Para dormir utilizam camas construídas com troncos rústicos, forrados com roupas e papelão e finos colchões ou camas industrializadas de baixo custo adquiridas no comércio de municípios vizinhos às aldeias.

No passado o vestuário consistia em saiotes de algodão denominados de xiripá, que presos por uma faixa na cintura, desciam até a altura dos joelhos. Costumavam depilar inteiramente o corpo, com exceção do crânio (SILVA 1949). Atualmente os saiotes são utilizados pelos homens somente nos ritos cerimoniais e são confeccionados com sapé ou palha de buriti.

No início constituíam um grupo com contatos esporádicos com membros da sociedade envolvente, sendo intensificado com a participação dos Terena na Guerra do Paraguai, como aliados das forças do Império e na defesa de suas aldeias, que foram invadidas, saqueadas e desagregadas com a fuga de seus componentes para as Serras de Bodoquena e Maracaju. Este fato marca provavelmente o surgimento de uma consciência política peculiar, como a de perceber a existência de uma categoria mais ampla, chamada nação brasileira, a que passaram a pertencer compulsoriamente (OLIVEIRA 1978).

ROSA (1985), grande escritor brasileiro, descreveu os Terena através da língua: "Conversa pouca. A surpresa que deram foi ao escutá-los coloquiar entre si, em seu rápido, ríspido idioma. Uma língua não propriamente gutural, não guarani, não nasal, não cantada; mas firme, contida, oclusiva e sem molezas - língua para gente enérgica e terra fria. Respeitei-a, pronto respeitei seus falantes, como se representassem alguma cultura velhíssima (p.93). (....) Toda língua são rastros de velho mistério" (p.95).

\subsection{Território Indígena}


Falar em território Terena, significa dizer que este é um espaço da sobrevivência e reprodução, onde se realiza a cultura, onde se criou o mundo, onde descansam os antepassados. Além ser um local onde se apropriam dos recursos naturais e garantem sua subsistência física.

A apropriação de recursos naturais não se resume em produzir alimentos, mas consiste em extrair matéria-prima para a construção de casas, para produção de enfeites e artesanatos e para a extração de ervas medicinais, que exigem determinadas condições ecológicas para se reproduzirem. $\hat{E}$, sobretudo, um espaço simbólico em que as pessoas travam relações entre si, com a natureza e com seus deuses (FERNANDES 1993).

A organização política das áreas indígenas, após a Guerra do Paraguai, sofreu alterações, passando à jurisdição das autoridades de Mato Grosso, não mais dependendo da organização social familiar. Com a guerra, o retorno das populações indígenas não se deu para as áreas de origem, pois muitas delas tinham sido destruídas (OLIVEIRA 1968).

As autoridades brasileiras selecionavam e elegiam, nas várias povoações, um líder, denominado de capitão, com quem estabeleciam contato e forneciam um título sobre a área em que o grupo deveria se estabelecer. $O$ efeito da seleção de um líder, para representar o grupo, foi o de destruir a organização dual dos chefes cerimoniais. Com o término das guerras intertribais, o chefe guerreiro também deixou de existir e a unidade da familia e do parentesco foi enfraquecida. Os casamentos entre opostos tornaram-se comuns e as cerimônias tradicionais foram modificadas (OBERG 1949).

Em torno de 1904, a Comissão de Linhas Telegráficas e Estratégicas de Mato Grosso ao Amazonas, conhecida como a Comissão Rondon, percorreu a região meridional de Mato Grosso, construindo as linhas telegráficas, sendo acompanhado pelo surgimento de latifúndios, onde a mão-de-obra indígena viu-se incorporada à economia regional. Se antes havia servido de produtora de bens agrícolas para um comércio irregular, organizado em termos de troca de produtos primários, agora sua vinculação à ordem social e econômica regional passava a institucionalizar-se de duas maneiras: como cativos, em posição simétrica aos escravos remanescentes ou como peões "livres", ainda presos às fazendas por meio de contas intermináveis, assumidas compulsoriamente com os proprietários das fazendas (OLIVEIRA 1968). 
As primeiras reservas indígenas Terena datam de 1904, como conseqüência da ação de Rondon à frente da Comissão de Linhas Telegráficas. Nesse período foram criadas as reservas de Cachoeirinha, Bananal/Ipegue e Lalima, todas no município de Miranda, época em que o Marechal Cândido Rondon teria incentivado os Terena, dispersos em fazendas da região, a localizarem-se na reserva Lalima, de remanescentes Guaikuru, cujas terras haviam sido doadas pela monarquia (OLIVEIRA 1968).

Entende-se por reserva, área territorial destinada ao aldeamento de indígenas, sendo que nem sempre estas áreas coincidiam com as terras tradicionalmente ocupadas pelas respectivas comunidades e muitas vezes com justaposição de grupos, provocando disputas e graves conflitos internos. A formação de reservas próximas de vilarejos evidencia o reconhecimento dos direitos indígenas a um território, ao mesmo tempo em que, ao agrupá-los, libera grandes áreas para o povoamento da região e impulsiona a integração à sociedade envolvente (PAULETTI 2000).

Os índios "bravos" - entendendo-se como "bravos" todos aqueles que não se sujeitavam facilmente às regras da sociedade envolvente - representavam o maior obstáculo para a efetiva ocupação e colonização da região. $\mathrm{Na}$ concepção dos governantes, eram eles que afugentavam a população e, portanto, tornava-se necessário, antes de tudo, afastá-los das áreas cobiçadas (VASCONCELOS 1999).

A ação protetora de Rondon foi acompanhada de legislação estadual de colonização, que colocava as terras indígenas à mercê de especulação, pois além da venda de terras por preços irrisórios, concediam terras gratuitas a imigrantes nacionais e estrangeiros. Todas as terras consideradas devolutas, dentre elas as terras indígenas, ficaram sujeitas à apropriação por particulares (VASCONCELOS 1999).

Até 1919, Lalima não havia conseguido atrair um número significativo de indivíduos Terena e, somente em 1925, com a efetivação do recenseamento realizado pelo Serviço de Proteção aos Índios (SPI), verificar-se-ia aumento da população, que, em seis anos, dobrava de número, passando de 130 para 261 habitantes. O aumento da população de Lalima, nesse período, coincide com a instalação de numerosas familias Terena em Francisco Horta, reserva dos índios Guarani-Kayoá, no município de Dourados. Esta reserva, que teve a posse de seus 3600 hectares em 1917, começou a receber migrantes Terena por volta de 1924. Ao contrário de Lalima, que viu seus tradicionais habitantes Guaikuru superados em número pelos 
migrantes Terena e demais remanescentes Guaná, Francisco Horta continuou tendo nos Kayoá-Guarani sua população majoritária (OLIVEIRA 1968). A forma de aldeamento da politica indigenista oficial não considerou as caracteristicas culturais diferenciadas de cada povo e uniformizou-as (MANGOLIM 1993).

Essas duas áreas, de composição étnica múltipla, foram povoadas de índios Terena na mesma época em que outras eram estabelecidas, como a de Capitão Vitorino, criada em 1922, com 2800 hectares no município de Nioaque, e a de Moreira/Passarinho, em 1925 (OLIVEIRA 1968).

Com relação às áreas indígenas estudadas, a área Buriti foi demarcada em 23 de dezembro de 1927, com 2.090 hectares, sendo instalada pelo Serviço de Proteção aos Índios (SPI), em 1928 e homologada em 1991, onde se localizam atualmente as aldeias Buriti, Água Azul e Córrego do Meio. A área Buritizinho, situada nos arredores do município de Sidrolândia, foi demarcada em 9 de julho de 1984 com 10 hectares, denominada aldeia Tereré (MANGOLIM 1993).

Com a instituição da Fundação Nacional do Índio (1967) e do Estatuto Indígena (1973) eram esperados avanços na regularização fundiária das terras, considerando o estabelecimento do prazo de cinco anos para a demarcação de todas as terras indígenas (BRASIL 1967; BRASIL 1973). O tempo passou e as propostas não foram cumpridas. Quanto ao reconhecimento da especificidade cultural desses povos, a proposta é considerada ambígua, pois, ao mesmo tempo que definia como uma de suas metas a proteção da cultura indígena, estabelecia como programa de governo a integração dos índios à sociedade nacional, de acordo com o mesmo modelo adotado no período colonial (FUNAI 1995).

No início da década de 80 , a discussão da questão indígena retorna no âmbito da sociedade civil, resultando avanços no texto constitucional como o reconhecimento da organização social, costumes, línguas, crenças e tradições e o direito originário sobre as terras que tradicionalmente ocupam (BRASIL 1988). A promulgação da Constituição Federal (1988) tornou clara a necessidade da adequação dos órgãos de assistência indígena ao novo contexto.

A Constituição brasileira dispõe no artigo 67 do Ato das Disposições Constitucionais Transitórias: "A União concluirá a demarcação das terras indígenas no prazo de cinco anos a partir da promulgação da Constituição" (BRASIL 1988). A Constituição foi promulgada em 5 de outubro de 1988, as terras indígenas deveriam 
estar totalmente demarcadas até 5 de outubro de 1993 e ainda falta demarcar quase a metade das terras indigenas.

Atualmente são trinta e nove áreas indígenas no Estado, divididas em cinqüenta e cinco aldeias e a situação fundiária dessas terras são: oito identificadas, três declaradas/delimitadas, quatro reservadas, oito homologadas e dezesseis registradas (CIMI 1997).

De acordo com dados do censo demográfico de 1991, existiam 32.759 indígenas no Estado de Mato Grosso do Sul, sendo 28.927 na área rural e 3.832 residentes na área urbana. A distribuição, segundo grupos de idade, indicava 5.628 crianças na faixa etária de 0 a 4 anos (FIBGE 1994). No último censo, a categoria "índio" foi incluída no quesito cor, não sendo considerada como unidade a etnia e o recenseamento, cobrindo apenas as populações que residiam em postos indígenas da FUNAI ou em missões religiosas (SILVA 1994).

Dados da FUNAI (1995) indicam 45.259 índios no Estado de Mato Grosso do Sul, a Fundação Nacional de Saúde (FUNASA) aponta 36.607, mas para o Conselho Indigenista Missionário (CIMI) existem 51.208 índios, sendo 42.472 índios em aldeias, 8.736 fora das aldeias e aproximadamente 17.632 Terena distribuídos em onze áreas, conforme ilustra o Anexo 7 (MANGOLIM 1993).

\subsection{Organização Social}

Os Terena possuem organização dual onde um grupo é denominado de "sukirikiono" (pacíficos) e outro de "shumono" (belicosos). Paz, serenidade, paciência de um lado, e, briga, astúcia e malícia de outro, são alguns dos atributos conferidos às metades e por meio dos quais assume a sociedade Terena o seu caráter dual. Segundo SILVA (1949), esta divisão sugere a representação da maturidade séria e tranqüila dos primeiros e a juventude irrequieta e brincalhona do segundo grupo. Embora a divisão seja cerimonial, no passado ela exercia controle social sobre seus membros, regulamentando casamentos e agindo politicamente nas decisões do conselho. Contudo, na vida cotidiana nada distingue os membros dos grupos, somente nas cerimônias o comportamento é distinto.

O cerimonial, chamado oheokoti, é constituído por um conjunto de práticas religiosas e profanas, tendo como uma das atividades tradicionalmente realizadas a 
provocação dos shumono sobre os sukirikiono, hoje encenada através da ihiyoti evoi kipae (dança da ema), que se constitui em uma dança, na qual os participantes (somente os homens) são dispostos em duas fileiras de igual número, executando uma luta cadenciada, ao som de um pepêke (tambor) e uma huxô'e étakati (flauta). $\hat{E}$ dedicado o culto aos mortos e a práticas propiciatórias de boas colheitas, realizado na época em que a constelação das sete estrelas (plêiades) alcança altura máxima no céu, por volta do mês de abril. O personagem central é o koixomuneti (líder espiritual), conhecido também por xamã. Todas as famílias participam da festa, distribuidas entre os preparativos como coletar frutos, castanhas e mel; produzir roupas, colares, brincos e cocares; preparar tintas; preparar as crianças; construir barracões de palha; cavar vala para assar as carnes e buscar patrocinio para aquisição dos alimentos do almoço coletivo, geralmente entre fazendeiros e políticos da região.

A origem telúrica dos Terena, a par de sua existência como povo agricultor, torna extremamente íntima a relação entre os hoipihapati (espírito dos mortos) e o cultivo da terra, dando perfeita unidade aos rituais do cerimonial (SILVA 1949).

Cada aldeia possui um líder (cacique), sendo o representante formal da comunidade, mas sem funções punitivas, limitando-se a aconselhar e advertir, quando necessário. A autoridade do cacique é aceita e exercida como um serviço benéfico e gratuito prestado à coletividade.

A sucessão dos líderes é controlada pela vontade dos integrantes e as decisões são tomadas no Conselho de Homens, geralmente com muitos conflitos e divisões devido à interferência política dos municípios próximos às aldeias, que desconhecem e desrespeitam as estruturas da sociedade Terena. As mulheres não são elegíveis para a chefia, nem participam do Conselho, mas opinam sobre as discussões coletivas.

A sociedade Terena possui um sistema político e social que promove a interação entre seus membros. Cada indivíduo tem um papel, dado pela família a que pertence, sua situação social e econômica, sexo e sua faixa etária.

A aldeia Tereré, uma das aldeias onde se desenvolveu a pesquisa, conta com um líder espiritual (Koixomuneti), que, quando jovem, teve um sonho onde foram revelados todos os ensinamentos que possui. Atualmente com 88 anos, não escolheu seu sucessor e não se preocupa como será após sua morte, afirmando com clareza que um sonho revelará um novo xamã. 
$\mathrm{Na}$ sociedade Terena não se produzem xamãs, no sentido de haver uma preparação, um aprendizado. Para este grupo, os sonhos são definidores e somente os homens podem tornar-se xamãs. O fundamental é a vocação para o xamanismo, revelada através de um sonho especial. As mulheres podem ser rezadoras, conhecedoras de plantas medicinais e de orações e cânticos terapêuticos. Nas aldeias estudadas foram identificadas senhoras idosas, conhecidas como "vovós tronco" que desempenham como muita propriedade a "reza" e a "bênção".

A doença não é o único objeto de atenção do xamã. É ele que tem contato com o sobrenatural, que dialoga com os espíritos e com as forças da natureza e que conhece os segredos de seu povo (FERNANDES 1993).

A religião Terena consiste em um corpo de crenças e práticas. Acreditam em Itukoviche ("Deus superior"), nos heróis culturais gêmeos orekajuvakái, bem como em hoipihapati (todas as coisas têm alma) e na eficácia mágica de certas plantas, animais e objetos. O xamanismo é desenvolvido, onde o koixomuneti provê as necessidades do povo e conduz, por meio de rituais, para um relacionamento significativo com o mundo sobrenatural, auxiliando os indivíduos a enfrentarem azares e os perigos das ocupações econômicas, do amor e da saúde, esclarecendo e agindo sobretudo nas causas. Mas, acima de tudo, cabe-lhe reunir o povo nas festas, quando os homens dançam a dança da ema (ihiyoti evoi kipâe) e as mulheres a siputrena (putu-putu) (Anexo 8).

A organização circular das residências foi substituída pela organização do alinhamento residencial. Em muitas áreas essa mudança ocorreu como resultado da interferência de agências assistenciais ou religiosas, com determinação da localização e distribuição de casas em quadras e ruas. A maioria dos grupos domésticos são constituídos por famílias elementares, com um casal e filhos e uma minoria formada por dois a três casais e filhos. Esses dados retratam a mudança operada na organização dos grupos domésticos.

Com relação ao papel dos idosos nas famílias, diminuiu o poder que desfrutavam no passado como "indiscutíveis chefes de família". Isto deve-se, em grande parte, às mudanças entre status e riqueza, como resultado da ação individual na vida econômica e a existência do mercado de trabalho regional que criou condições para a ampliação da ação individual (OLIVEIRA 1968). 
A existência do mercado de trabalho regional e a absorção da mão-de-obra Terena sugerem significativa mobilidade espacial indígena, que também se manifesta no meio interno da comunidade indígena, devido à alteração na agricultura tradicional, à qual se vinculavam todos os componentes masculinos da família extensa, sob a liderança de seu chefe, com roças coletivas e trabalho sob a forma de mutirão permanente (OLIVEIRA 1968).

Os laços de parentesco mantém os membros da aldeia e dão coesão às classes. Possuem um sistema de parentesco em que tanto os primos do lado materno ou paterno são considerados irmãos, não sendo permitido o casamento entre primos, tios e sobrinhos, sendo o casamento monogâmico. Indivíduos "não parentes" podem se transformar em "parentes" através de laços de apadrinhamentos e pela convivência diária.

A família, como instituição social, desempenha, entre os Terena, importante papel no processo matrimonial. Para as jovens, o empenho em conseguir um companheiro encontra estímulo e orientação em sua família. Logo que as meninas saem da puberdade, são orientadas para imprimir aos namoros uma direção voltada para o compromisso; enquanto os homens, são persuadidos pelos pais a fixarem-se na aldeia, casando-se. O status social na comunidade é, também, um estímulo poderoso que lança o jovem ao matrimônio. Existe a expectativa dos pais da noiva em ver o noivo ser trazido por seus próprios pais para entrar na casa da noiva (uxorilocalidade) e nela permanecer, pelo menos durante o primeiro tempo de casados, para depois construírem a própria casa.

A condição de casado para o jovem Terena representa o seu atestado de maturidade, solidificado com o nascimento do primeiro filho. Nessa situação passa, então, a desejar ter sua própria casa e a chefiar um mutirão para construí-la, iniciando, aí, a constituição de seu poder de liderar (OLIVEIRA 1968).

O matrimônio Terena, conforme foi caracterizado, não pode ser considerado, entretanto, a única modalidade de união vigente nas áreas indígenas. Ocorrem amasiamentos com inexistência de contrato, onde os pais não são ouvidos e geralmente são contrários à união, especialmente nas aldeias localizadas próximas das cidades. 


\subsection{Trabalho}

A vida econômica nas sociedades indígenas organiza-se de modo a garantir sua reprodução e manutenção, com distribuição relativamente igualitária e não com a acumulação de bens ou capital. O modo de produção consiste em linhas gerais na utilização escalonada da natureza, mas sem a possibilidade de deslocamentos das plantações, devido à redução territorial.

No passado a organização da produção não incluía divisões que implicassem na posse diferencial de terra e dos meios de produção por grupos sociais específicos ou de outras condições que levassem à separação entre os trabalhadores, sua força de trabalho e os meios de trabalho. As divisões da população na produção eram relativas ao sexo e ao grupo etário dos indivíduos. O excedente da produção, quando verificado, era dividido ou trocado com outros grupos (CARVALHO 1987).

Os Terena constituem mão-de-obra básica das fazendas que se formaram nas proximidades das reservas. A reserva indígena tem significação definida, ela representa uma reserva de mão-de-obra suscetível de utilização nos níveis mais rudimentares de trabalho. Com o crescimento populacional, a importância diminuiu, sem contudo, deixarem de ser recrutados para os trabalhos agrícolas, extração de madeiras e de pastoreio, continuando a garantir, dessa maneira, lugar no mercado de trabalho regional (OLIVEIRA 1968).

Os Terena não atingem altos índices de produção agrícola, mas contam com uma pequena produção que lhes permite manter um contato com a sociedade regional no nível de atividade comercial. Uma roça produtiva é a aspiração de todo Terena.

A participação dos Terena no mercado de mão-de-obra regional não se limita, entretanto, às modalidades mencionadas. As empresas vizinhas às áreas indígenas têm utilizado, segundo sua peculiaridade produtiva, mão-de-obra Terena. A presença de usinas, beneficiadoras de cana-de-açúcar próximas às aldeias, torna a população indígena uma força de trabalho suscetível de utilização, por longos períodos, em atividades de corte da cana, plantio e limpeza do terreno. O que se verifica é que, as atuais áreas indígenas são insuficientes para satisfazer as necessidades de reprodução das populações nelas existentes, seja pela redução territorial, pelo empobrecimento do solo, desmatamentos sucessivos com alteração das reservas naturais, além de 
outras razões, de ordem sociocultural, que os levam a buscar trabalho e sobrevivência fora das aldeias.

A atração que a cidade exerce na população Terena é justificada pela perspectiva de melhor remuneração, assistência médica e educação para os filhos. Segundo OLIVEIRA (1968), a breve permanência nas cidades ou o simples trânsito por elas são suficientes para revelar ao Terena um novo mundo, particularmente atraente aos jovens, ansiosos por aventuras que a vida na aldeia e o ambiente regional circunvizinho não lhes podem proporcionar.

A mobilidade é intensa e o Terena normalmente vai à cidade para realizar pequenas compras mensais, receber benefícios da previdência social ou passa por ela quando vai trabalhar em locais distantes de suas aldeias.

O Terena dificilmente abandona sua área, uma vez que emigra somente quando se sente hostilizado por um grupo ou pelo encarregado pelo posto indígena, mantendo ainda o vínculo com familiares e realizando visitas periódicas (OLIVEIRA 1968). Quando isso ocorre, normalmente passa a viver na periferia das cidades ou busca trabalho e abrigo em fazendas da região, o que provoca alterações na vida do indivíduo e da família a que pertence. 


\section{NUTRIÇÃO E SAÚDE}

Estudos que fazem referência ao processo de determinação do perfil nutricional apontam para a complexa rede de determinantes, como as políticas públicas, distribuição de renda, poder aquisitivo das famílias, condições de vida e moradia, produção, consumo e utilização biológica dos alimentos, acesso aos serviços de saúde, entre outros (ARIZA MACIAS et al., 1980; BATISTA FILHO e SHIRAIWA 1989; BEGHIN et al., 1989).

$\mathrm{Na}$ infância, a avaliação do crescimento é o parâmetro que reflete com maior clareza o estado de saúde e nutrição dos indivíduos, por outro lado, em coletividades, a distribuição dos valores da estatura das crianças de diversas faixas de idade é sensível indicador da qualidade de vida a que está submetida essa população (MONTEIRO et al., 1989). A importância da avaliação nutricional decorre da influência decisiva que o estado nutricional exerce sobre os riscos de morbimortalidade, crescimento e desenvolvimento infantil (MONTEIRO et al., 1995).

O crescimento do corpo humano é um fenômeno observável e está determinado por fatores genéticos e ambientais, entre os quais o aporte de nutrientes e as doenças infecto-contagiosas (ORGANISATION MONDIALE DE LA SANTÉ 1978).

O ritmo de crescimento na espécie humana varia não só com a idade e o sexo dos indivíduos, mas também devido às características individuais e sua relação com inúmeros fatores ambientais que vão mediando o crescimento e desenvolvimento, interferindo na sua evolução e produto final (LEVY 1977).

A possibilidade de que a nutrição em fases precoces da vida possa influenciar uma doença na vida adulta se origina a partir de conceitos da biologia do desenvolvimento e foi redefinida por LUCAS (1995) como o processo no qual um estímulo ou insulto aplicado em um período crítico ou sensível do desenvolvimento resultaria num efeito permanente, ou a longo prazo da estrutura ou função do organismo.

O estudo científico do crescimento humano teve início em 1777 na França, por Buffon e Montbeillard, onde descreve o primeiro estudo longitudinal do crescimento 
humano atribuído ao Conde Montbeillard, que registrou e relatou as medidas de seu filho, desde o nascimento até os 18 anos, em intervalos semestrais (TANNER 1978).

Na primeira metade do século XIX, o estatístico Quetelet idealizou o primeiro estudo antropométrico transversal em grande escala, na população de 0 a 20 anos de idade de escolas e de um Hospital de Bruxelas, no qual é proposta a distribuição da curva normal para estatura e índice de Quetelet. Em 1830, fez outros levantamentos, entre eles, comparou o comprimento de 50 recém-nascidos de ambos os sexos, através da distribuição de freqüências, observando pela primeira vez que os meninos eram maiores do que as meninas (TANNER 1978).

Quetelet e Villermé (1830) conduziram estudos mostrando diferenças quanto à morbidade e mortalidade em relação ao crescimento linear, sendo consideradas como o resultado de diferenças nas condições de vida, surgindo, a partir de então, aplicação social dos estudos do crescimento humano (TANNER 1978).

Os estudos iniciais da desnutrição centralizavam-se nas formas clínicas graves, quando era então considerada como problema de saúde pública de natureza médica. A desnutrição era caracterizada como produto da falta de um nutriente isolado. Mais tarde, quando se distinguiram as fases intermediárias na evolução da desnutrição, passou-se a reconhecer os vários níveis de organização e suas relações, permitindo entender a fisiopatologia da doença como processo (LEI 1994).

Segundo CAMERON (1984), no início do século foram desenvolvidos estudos somáticos do crescimento, a partir do acompanhamento longitudinal da população americana, destacando-se os trabalhos de Frank Shuttleworth no Estudo de Crescimento de Harvard (1922), de Harold Stuart no Centro de Pesquisa em Saúde Infantil e Estudos do Desenvolvimento (1930) e de Katherine Simmons realizado através da Fundação Brush (1931). Na década de 40, na América Latina, aparecem estudos classificando a desnutrição não só em termos de formas graves, mas também de formas leves e moderadas, delineando-se a valorização do diagnóstico precoce com a introdução do critério de Gomez (GOMEZ 1946).

A partir de levantamentos pelo Interdepartamental Committee on Nutrition for National Defense (ICNND), são mapeados problemas de desnutrição, evidenciando os aspectos sociais, reconhecendo as relações entre desnutrição e precárias situações socioeconômicas. No manual publicado, para investigações nutricionais, é ressaltado que, para melhor compreensão do problema nutricional, devem ser considerados 
fatores econômicos e sociológicos, juntamente com os dados sobre nutrição e saúde (GOLDENBERG 1989).

Esses estudos foram estendidos para a América Latina e outros países em desenvolvimento. A partir daí, a nutrição passa a ser um dos pontos estratégicos de intervenção para a promoção do desenvolvimento. Agências internacionais orientamse para a promoção do desenvolvimento dos países pobres, criando-se órgãos específicos voltados para a nutrição (SIGULEM et al., 1978).

Depois da II Guerra Mundial, o desenvolvimento econômico era entendido como sendo equivalente ao crescimento do produto interno bruto, acreditando-se que um investimento intensivo em capital e tecnologia levaria os países em desenvolvimento a caminharem para um crescimento auto-sustentado. No entanto, diante do real número de desempregados, analfabetos e desnutridos nesses países, iniciou-se a discussão em torno do desenvolvimento socioeconômico com redistribuição que, por sua vez, deveria envolver o crescimento econômico e também as necessidades humanas básicas, valorizando-se a eqüidade social (MOCK e BERTRAND 1993). Perpassaria, portanto, os vários setores das políticas governamentais, incluindo-se as de alimentação e nutrição, cuja meta seria a erradicação da desnutrição (MANSON et al., 1984).

JELLIFFE (1958) sistematizou a antropometria como método de avaliação do estado nutricional, sendo um marco para o desenvolvimento da antropometria nos países industrializados, alcançando os países em desenvolvimento a partir da metade da década de 70 .

Em 1960, a FAO lançava a campanha mundial contra a fome, chamando atenção para a gravidade do problema, que afetava $50 \%$ da população mundial (SIGULEM et al., 1978). No início da década de 70, Selowsky e Berg, citados por SIGULEM et al., (1978 p.19), introduzem a teoria do capital humano na análise dos problemas nutricionais. Dentro deste enfoque, a variável nutrição passa a ser considerada como um instrumento técnico de política econômica, para acelerar a expansão da capacidade produtiva e a acumulação de capital.

BERG (1973), delineando os fundamentos da aplicação da teoria do capital humano, refere que os gastos em nutrição se constituem, na verdade, em investimentos, na medida em que contribuem para o aumento da produtividade, presente e futura, da mão-de-obra, seja pela diminuição do absenteísmo por doença, 
seja em função da melhoria da capacidade física e mental. Indiretamente, o combate à desnutrição concorreria para uma maior eficiência dos gastos em educação, uma vez que melhoraria as condições de aprendizado, assim como dos investimentos em saúde.

EVELETH e TANNER (1976) analisaram estudos sobre o crescimento humano de várias partes do mundo e em suas conclusões observaram que europeus crescem de maneira semelhante, embora sejam encontradas diferenças entre as populações mais pobres e as mais ricas; os africanos e os indo-mediterrâneos, quando sob boas condições de vida, crescem de maneira similar aos europeus; os asiáticos, mesmo vivendo sob condições adequadas, são mais baixos que os europeus e os africanos. Os autores sugerem que há prováveis diferenças genéticas entre as populações, no tamanho do corpo, assim como no processo de maturação e que muitos fatores ambientais influenciam a taxa de crescimento, sendo a maior parte dependente do estado nutricional, agindo em conjunto com as infeções.

No Brasil, o primeiro inquérito antropométrico nacional foi realizado em 1975, fazendo parte do Estudo Nacional da Despesa Familiar (ENDEF). O interesse da Fundação Instituto Brasileiro de Geografia e Estatística (FIBGE) em obter informações sobre orçamentos familiares em uma ampla pesquisa nacional, na qual se deu maior atenção aos dados sobre consumo alimentar, coincidiu com a orientação dos trabalhos da Divisão de Nutrição da Food and Agricultural Organization (FAO), tendo como objetivo principal permitir uma avaliação de aspectos qualitativos e quantitativos do estado nutricional das famílias (FIBGE 1978).

Em 1977, realiza-se, em Recife, um seminário sobre Economia da Nutrição, reunindo economistas e profissionais de saúde, onde Batista Filho ressalta a necessidade de circunscrever o combate à desnutrição como um fim do desenvolvimento, levantando-se debates a respeito da validade da utilização da Teoria do Capital Humano, que reconhece a saúde e educação como componentes estratégicos do desenvolvimento. Além disso, apontou-se para a necessidade de superar a dissociação entre as áreas econômica e da saúde, visando ultrapassar os enfoques sobre alimentação, vista como um simples componente da área de mercado (BATISTA FILHO 1978).

O processo de reelaboração das formas de analisar a realidade, a busca de conexões empíricas entre a saúde infantil e a organização social, provocaram a 
realização de novos estudos. A Pesquisa Nacional sobre Saúde e Nutrição (PNSN 1989), teve como objetivo central a aferição do estado nutricional da população brasileira, onde a primeira publicação feita sobre esta pesquisa era relativa à situação nutricional de crianças até cinco anos de idade. O estudo indicava uma prevalência de déficit nutricional no país como um todo de $15,4 \%$, considerando apenas as formas moderadas e severas e $2,0 \%$ de déficit de peso/estatura (FIBGE. UNICEF. INAN 1992).

MONTEIRO e IUNES (1994), comparando os resultados percentuais dos inquéritos antropométricos realizados em nível nacional (ENDEF/1975 e PNSN/1989), evidenciam o significativo progresso do estado nutricional de crianças brasileiras, pela redução de cerca de $60 \%$ na prevalência de crianças com baixo peso. Os beneficios foram relativamente menores para os estratos que partiram de prevalências mais elevadas, no caso a população das regiões norte e nordeste e as famílias de menor renda. Tal tendência acabou determinando a ampliação dos diferenciais regionais e socioeconômicos já elevados, observados em 1975 (MONTEIRO et al., 2000a). A alteração do quadro nutricional da população brasileira tem sido atribuída a fatores relacionados às mudanças econômicas e demográficas ocorridas, não sendo mais caracterizado exclusivamente pelo déficit, mas também pelo aparecimento da obesidade (MONDINI 1996).

O conceito que melhor sistematiza esta tendência de evolução é o de transição epidemiológica, por conferir uma abordagem dinâmica e articulada com as mudanças no perfil demográfico e socioeconômico da população. Este conceito refere-se às complexas alterações nos padrões de saúde e doença que ocorrem em populações específicas, através do tempo (PRATA 1994).

POST et al (1995) avaliaram as mudanças nos indicadores antropométricos ocorridos entre 1982 e 1993, em Pelotas, Rio Grande do Sul. No período de onze anos, a prevalência de déficit de peso/idade caiu de $5,4 \%$ para $3,8 \%$, enquanto que a de peso/estatura reduziu-se de $1,3 \%$ para $0,8 \%$. A prevalência de retardo de crescimento linear aumentou de $5,3 \%$ para $6,1 \%$, enquanto que a obesidade cresceu de $4,0 \%$ para $6,7 \%$, passando a ser mais freqüente do que os déficits nutricionais.

Com relação a estudos desenvolvidos no Estado de Mato Grosso do Sul, é importante destacar o do município de Campo Grande (1995), onde os déficits nutricionais encontrados em crianças de zero a cinqüenta e nove meses de idade, 
foram baixos quando comparados com prevalências em nível nacional, e aceitáveis, dentro dos valores indicados pelo padrão de referência, para uma população saudável, sendo $3,2 \%$ para déficits de peso/idade e $1,2 \%$ de peso/estatura. A exceção ocorreu com os valores obtidos pelo índice estatura/idade, com prevalência de $6,3 \%$, com as formas crônicas de desnutrição, tendo início ainda no primeiro ano de idade. $\mathrm{O}$ estado nutricional mostrou-se influenciado pelas condições socioeconômicas da família, onde crianças de 0 a 59 meses de idade apresentaram déficit nutricional com maior freqüência quando pertenciam a famílias de renda familiar per capita inferior a um salário mínimo e chefe de família com nível de escolaridade até o primeiro grau. A prevalência de obesidade encontrada foi de 3,5\% (RIBAS 1997).

$\mathrm{Na}$ avaliação do estado nutricional de crianças índias do Alto Xingu, realizado pela Escola Paulista de Medicina, na década de 70, as prevalências de déficits nutricionais foram de $1,0 \%$ nas crianças menores de um ano, 2,8\% entre um e cinco anos e 1,1\% nas crianças com mais de cinco anos (MORAIS et al., 1990).

Em estudo realizado na comunidade indígena Cashibo, localizada na Amazônia Peruana, foi identificada a prevalência de $16,4 \%$ de déficits nutricionais de $1^{\circ}$ grau e $3,0 \%$ de $2^{\circ}$ grau, onde fatores como a desintegração do grupo, mudanças de hábitos alimentares tradicionais, degradação dos valores culturais, modificação da economia e implantação da monocultura foram apontados como responsáveis por tais resultados (BOURÉE et al., 1985). Em 1991, entre crianças indígenas Parakanã menores de cinco anos, foram observados déficits nutricionais de 10,1\% de peso/idade e $50,6 \%$ de estatura/idade, o que representa valores superiores às médias nacionais, configurando a gravidade da situação nutricional desses povos (MARTINS e MENEZES 1994). Entre os Enawene-Nawe foram encontradas as prevalências de $5,6 \%$ de déficits nutricionais de peso/estatura e $50 \%$ de estatura/idade (WEISS 1998).

Em comunidades indígenas Terena do Mato Grosso do Sul, estudo antropométrico, realizado por WILLEMS (1947), em 26 indivíduos adultos tinha como objetivo identificar a variação de medidas e comparar com outros grupos indígenas da região do Chaco. O estudo analisou a estatura total, estatura troncocefálica, largura e altura da cabeça, face, orelha e nariz, diâmetro de ossos da face e comprimento e largura da mão esquerda. Com relação à estatura total, foram identificados valores médios de $161,7 \mathrm{~cm}$ para os homens e $149,7 \mathrm{~cm}$ para as 
mulheres, sendo classificados na categoria de sub-medianos. Este trabalho fazia parte do levantamento antropológico dos índios do Brasil meridional, executado por pesquisadores da Escola de Sociologia e Política e Faculdade de Filosofia, Ciências e Letras da Universidade de São Paulo. A ausência de outros estudos entre os Terena, por si só, justificaria a realização deste, uma vez que informações epidemiológicas adequadas sobre a saúde infantil são imprescindíveis no planejamento e avaliação de ações de saúde das crianças indígenas.

\subsection{Antropometria}

A antropometria nutricional baseia-se na observação de que os fatores externos, entre eles a alimentação, tem efeito direto sobre o crescimento e a composição corporal da criança. Constitui-se num conjunto de princípios e técnicas pelas quais se avalia o estado nutricional e o crescimento (MARTORELL 1981).

Sua utilização no monitoramento das condições de saúde de crianças menores de cinco anos baseia-se em duas premissas concernentes à utilidade dos parâmetros antropométricos: a) que é possível detectar mudanças no estado nutricional pela observação do desenvolvimento da criança; b) que é possível utilizar as medidas antropométricas para identificar crianças sob alto risco de morte pela definição de pontos de corte na distribuição das medidas antropométricas, tendo em vista o fato de que o estado nutricional precário está associado com um risco mais elevado de morte por causa prevenivel (MONTEIRO 1988).

A antropometria ocupa-se da medição das variações nas dimensões físicas e na composição global do corpo humano em diferentes idades e em distintos graus de nutrição (JELLIFFE 1968). As medidas antropométricas mais utilizadas são a massa corporal, expressa pelo peso; as medidas lineares como a estatura e os perímetros cefálico, torácico e braquial e a gordura subcutânea através de dobras cutâneas como triciptal, subescapular e supra-ilíaca. Essas medidas utilizadas isoladamente ou de forma combinada, quando comparadas com um padrão de referência, possibilitam a identificação de indivíduos com risco nutricional, permitindo estimar o crescimento sob diferentes aspectos.

A escolha deste método no diagnóstico de alterações nutricionais, justifica-se pela facilidade de execução, baixo custo, confiabilidade dos dados e importância no 
diagnóstico precoce da desnutrição, pois a primeira manifestação deste déficit é a perda ponderal. A confiabilidade dos dados depende do rigor aplicado às medidas, que permitirá compará-las com outros estudos (WHO 1995).

O crescimento traduzido em peso e estatura é a melhor expressão do estado de saúde de crianças, testemunhando as condições de vida às quais estão submetidas (HAMILL et al., 1979).

$O$ peso pode sofrer rápidas e intensas alterações em intervalos curtos de tempo, como a variabilidade diária de fluidos e conteúdo intestinal. A estatura é uma medida mais estável do que o peso e não sofre reduções, assim, os déficits de estatura indicam duradoura restrição alimentar, sendo considerado como um indicador da evolução histórica da situação socioeconômica e nutricional de uma população (WHO 1995).

As medidas de peso e estatura são convertidas nos valores de três índices: peso para estatura, peso para idade e estatura para idade e comparados à população de referência. $\mathrm{O}$ índice peso para estatura $(\mathrm{P} / \mathrm{E})$ é a relação entre o peso observado e $\mathrm{o}$ peso de referência para estatura. Indica déficits nutricionais atuais ou agudos e tem a vantagem de ser realizada sem que a idade seja conhecida. É um indicador antropométrico recomendado para intervenções alvo contra obesidade (WHO 1995).

Considera-se que, em uma população bem nutrida, no máximo $2,5 \%$ de crianças até sete anos poderão apresentar valores de P/E abaixo de menos 2 desviospadrão. Em área menos desenvolvida, que não atravesse crise nutricional, $5 \%$ das crianças abaixo de cinco anos podem encontrar-se abaixo desse limite. Considera-se que taxas de desnutrição maiores do que $8 \%$ são motivos de alerta (MINISTÉRIO DA PREVIDÊNCIA E ASSISTÊNCIA SOCIAL 1983).

$O$ índice estatura para idade $(E / I)$ é a relação entre a estatura observada e a estatura de referência para idade. Retrata o desempenho do crescimento linear, é um indicador da história nutricional, é sensível a processos crônicos de desnutrição, relacionando-se com os fatores que atuam sobre o estado nutricional a longo prazo, tais como renda familiar e a educação materna (BAIRAGI 1987).

$\mathrm{O}$ índice peso para idade (P/I) é a relação entre o peso observado e peso de referência para idade. É um indicador que não discrimina o período em que ocorreu o déficit alimentar (WATERLOW et al., 1977). O índice peso para idade é largamente 
utilizado e sensível para detectar alterações da massa corpórea, mas pouco específico para identificação da desnutrição proteico-calórica, a partir de uma única observação.

A classificação baseada no índice P/I foi proposta por GOMEZ et al (1956) para definir graus de desnutrição (primeiro grau ou desnutrição leve, segundo grau ou desnutrição moderada e terceiro grau ou desnutrição grave), considerando o percentual de déficit do peso real em relação ao peso teórico médio para a idade. Esta classificação tinha por finalidade orientar no prognóstico de crianças hospitalizadas (GOMEZ et al., 1956).

O sistema de classificação Gomez (1956) estabeleceu limites para a normalidade e graus de desnutrição, empregando a proporção entre o peso observado e o peso considerado normal para uma criança da mesma idade e sexo. Esta classificação indica como desnutridas as crianças com pesos inferiores a $90 \%$ do peso médio esperado para a idade, segundo o padrão de Harvard (GOMEZ et al., 1956). Ao longo de sua utilização, esta classificação sofreu críticas que apontam limitações, como a baixa especificidade, pontos de corte determinados arbitrariamente e pouco justificados do ponto de vista físiológico ou estatístico e supervalorização dos casos de obesidade e de desnutrição (MONTEIRO et al., 1986).

A partir da década de 70, surgem novas classificações, com relação à adoção de novos padrões de referência e novos critérios de classificação em substituição ao de Gomez (1956). O sistema de classificação de Waterlow (1972) propõe uma combinação das relações estatura para idade e peso para estatura, para identificar manifestações de déficit de peso/estatura (wasting) e déficit de estatura/idade (stunting), bem como a presença simultânea de ambas (WATERLOW et al., 1977). $\mathrm{O}$ termo wasting indica um déficit de massa magra e massa adiposa comparado com o esperado numa criança de uma mesma estatura e pode resultar de perda de peso ou de não ganho de peso. O termo stunting indica retardo no crescimento ósseoesquelético.

Com relação a pontos de corte, na prática habitual recomendam-se pontos de corte universais. Estatisticamente, são apresentados como pontos de corte o valor abaixo de menos 2 escores $z$ e acima de mais 2 escores $z$ em relação à mediana da população de referência. Estes pontos de corte definem $95 \%$ da parte central da distribuição de referência como normalidade (WHO 1995). 
No documento da Organização Mundial da Saúde (OMS), aonde se propõe a adoção das curvas do National Center for Health Statistics (NCHS) como valores de referência internacionais, utilizam-se como pontos críticos menos 2 e mais 2 desvios-padrão para curvas normais, tanto para peso para idade, como para peso para estatura e estatura para idade (OMS 1983).

São denominados valores de referência quando servem de base para comparações entre populações. Os valores de referência podem ser internos ou externos, originados de populações sadias e bem nutridas, de amostras suficientemente grandes, reproduzíveis e explicitamente enunciados. As referências em crescimento humano são utilizadas no monitoramento do crescimento infantil. Das referências externas mais conhecidas, destaca-se o padrão NCHS, desenvolvido em Yellow Springs, Ohio, de 1929 a 1975 e que foi recomendado para ser utilizado como referência internacional, substituindo os padrões americanos de Harvard (1946), com a consideração sobre a vantagem do seu uso quando se deseja privilegiar a comparabilidade dos resultados (WATERLOW et al., 1977; OMS 1983; MINISTÉRIO DA PREVIDÊNCIA E ASSISTÊNCIA SOCIAL 1983; MONTEIRO 1984).

Em 1978, a OMS publicou gráficos e tabelas de crescimento em peso e estatura, para crianças menores de cinco anos, que foram revisadas em 1986, como padrões universais, para uso em populações que não haviam desenvolvido seus próprios padrões locais e com objetivo de facilitarem a comparação de dados de crescimento de diferentes populações do mundo (EVELETH 1986).

MARCONDES (1982) desenvolveu o padrão Santo André Classe IV (1975), a partir de estudos transversais realizados nas décadas de 60 e 70 , em crianças provenientes de famílias de alto nível socioeconômico de Santo André, São Paulo. Segundo MONTEIRO (1984), tanto o padrão Santo André Classe IV, quanto o padrão NCHS atendem de maneira semelhante às condições centrais de adequação dos padrões. A escolha de um deles dependerá da circunstância e de determinadas características marginais dos referidos padrões. Em estudos onde a comparabilidade de resultados for essencial, poderá ser mais vantajoso utilizar-se o padrão NCHS.

A discussão sobre a conveniência de utilizar uma referência universal única, como padrão de referência, teve início com um artigo de HABITCH et al. (1974), onde analisaram diversas amostras de dados de peso e estatura de crianças até sete 
anos, tendo como base os critérios de tamanho adequado da amostra e diferenças étnicas e socioeconômicas. Os resultados indicaram que entre crianças bem alimentadas, as diferenças de estatura na idade pré-escolar são relativamente pequenas, considerando os diferentes grupos étnicos. Entretanto, foram encontradas diferenças significativas entre os estratos socioeconômicos, sugerindo que os fatores ambientais influenciam o crescimento pré-escolar em estatura e peso em maior proporção que os fatores genéticos (HABITCH et al., 1974).

\subsection{Consumo Alimentar}

Em consonância com a transição epidemiológica e demográfica, estão ocorrendo mudanças nos padrões alimentares e nutricionais da população, revelando a complexidade dos modelos de consumo e de seus fatores determinantes, onde déficits nutricionais e obesidade coexistem, marcados por alterações nos níveis de atividade física e composição da dieta (OLIVEIRA e THÉBAUD-MONY 1997).

$O$ conceito de transição nutricional diz respeito a mudanças seculares em padrões nutricionais que resultam de modificações na estrutura da dieta dos indivíduos e que se correlacionam com mudanças econômicas, sociais, demográficas e relacionadas à saúde (POPKIN et al., 1993). Aspectos singulares da transição nutricional são encontrados em cada região, mas elementos comuns convergem para uma dieta rica em gorduras, açúcar e alimentos refinados e reduzida em carboidratos complexos e fibras (MONTEIRO et al., 1995).

A valorização e o conhecimento de padrões dietéticos são tema de grande importância no campo da saúde pública, contribuindo para fundamentar e orientar políticas de alimentação e nutrição, bem como constituírem-se em método preditivo para avaliar o estado de saúde da população (CINTRA et al., 1997).

No século XIX, estudos sobre consumo de alimentos em grupos populacionais tinham o propósito de estabelecer padrões dietéticos. $\mathrm{O}$ interesse antropológico pela alimentação de grupos indígenas era, essencialmente, em torno de aspectos religiosos, onde os tabus e os sacrificios relativos ao consumo alimentar eram a tônica desses trabalhos. Posteriormente, os fatos isolados foram contextualizados e a antropologia voltou-se para a função social da alimentação (VELTHEN 1996). 
Neste século, estudos desenvolvidos por órgãos oficiais passaram a ser realizados com o intuito não somente de estabelecer os padrões de recomendações em nutrientes e energia, mas, também, de orientar políticas governamentais no campo da saúde pública, tais como programas de suplementação alimentar a grupos vulneráveis e programas de educação em nutrição. Dados de ingestão alimentar também são usados como base para decisões na indústria de alimentos com contínua melhora na qualidade das informações (TRIGO 1993).

O reconhecimento da importância da dieta na etiologia de determinadas patologias tem impulsionado o desenvolvimento de métodos para a obtenção de informações dietéticas. Para o diagnóstico da situação alimentar e conseqüente atuação nesta área, faz-se necessária a adoção de métodos de análise, capazes de apreender os vários determinantes do consumo e de sua evolução, da natureza econômica, social, cultural, política e nutricional, assim como a interação entre eles (OLIVEIRA 1997).

Estudos de consumo alimentar implicam diferentes ordens de dificuldades, com relação à aferição precisa da ingestão alimentar, a transformação dos alimentos ingeridos em quantidades exatas de nutrientes e os indicadores de adequação. As técnicas para estimar a ingestão dietética podem ser classificadas em dois grupos. $\mathrm{O}$ primeiro grupo são os métodos quantitativos do consumo diário, que engloba os registros e os recordatórios que avaliam a quantidade de alimentos consumidos por um período equivalente às 24 horas anteriores ao consumo. Aumentando o número de medidas por esses métodos, pode-se obter estimativas da ingestão atual ou ingestão habitual dos indivíduos. O segundo grupo são os métodos qualitativos, que informam as tendências e os hábitos alimentares, representados pela história dietética e o questionário de freqüência alimentar, fornecendo informações retrospectivas sobre os alimentos usualmente ingeridos e em qual freqüência. $O$ objetivo de cada estudo dietético determinará o método a ser utilizado (MARR 1971; TRIGO 1993; CINTRA et al., 1997).

São apontadas como vantagens do método recordatório de 24 horas a rápida e fácil execução, o baixo custo, a necessidade de um só contato e a possibilidade de estimativa quantitativa do consumo atual. Como desvantagens a dependência da memória do entrevistado, os dados quantitativos dos nutrientes nem sempre são exatos, o consumo do dia anterior pode ser atípico, não representando a ingestão 
habitual e a necessidade de entrevistador experiente. Com relação ao questionário de freqüência alimentar são apresentadas como vantagens o baixo custo, a rapidez de execução, possibilidade de estimativa da ingestão habitual, modificações na dieta e observação de um nutriente específico ou grupo de alimentos. Como desvantagens são apontadas a perda de detalhes, quantificação pouco exata e requer memória de hábitos do passado (PAO e CYPEL 1996; PEREIRA et al., 1997; CINTRA et al., 1997).

Estudo de consumo dietético realizado em dezesseis comunidades indígenas do Canadá, demonstrou mudanças nos hábitos alimentares comparando a dieta de diferentes gerações $(20-40,41-60$ e 61 e + anos). Os dados foram obtidos pelo método recordatório de 24 horas, questionário de freqüência alimentar e questionário sociocultural. Os resultados encontrados demonstram redução de consumo de alimentos tradicionais nas gerações mais jovens e, na análise de nutrientes da dieta observou-se elevado consumo de carboidratos e gordura saturada nos grupos etários mais jovens, quando comparados com o grupo mais idoso (WHITING e MACKENZIE 1997).

Segundo WIRSING (1985) as drásticas mudanças ecológicas decorrentes do contato interétnico provavelmente geram um stress social e físico que se relaciona a um quadro desfavorável, como a privação de terras aliada à crescente pressão sobre os recursos naturais, 0 abandono de práticas tradicionais de subsistência e a sedentarização.

\subsection{Programas Assistenciais}

Os programas de atenção integral à saúde no Brasil têm como referência o lema "Saúde para todos no ano 2000", assumido na $30^{\mathrm{a}}$ Conferência Mundial da Saúde (1977) e a estratégia de atenção primária à saúde aprovada na Conferência de Alma-Ata (1978), tendo como eixo principal elevar a qualidade de vida da população mundial com a contribuição do setor saúde na diminuição das desigualdades sociais e eliminação da pobreza extrema, sendo definidas as prioridades em três áreas: populações de extrema pobreza em áreas rurais e urbanas e, nelas, as crianças menores de cinco anos, mulheres e trabalhadores e nos países cuja população já demonstrasse envelhecimento, deveriam também ser incluídos como prioritários os 
idosos; nível e estrutura de saúde, com aumento da esperança de vida ao nascer, através da diminuição e mudança do padrão de mortalidade; melhoramento dos níveis nacionais de bem-estar com aumento da disponibilidade e acessibilidade de toda população a serviços de saúde, educação, ambiente, alimentação, moradia e lazer, bem como, melhoria dos níveis de renda e emprego (WHO 1978; CASTRO 1995).

Foi proposto, ainda, que a prática de atenção primária seria adequada a cada realidade, devendo contemplar, pelo menos, a promoção de uma nutrição adequada, saneamento básico e atenção materno-infantil - incluindo planejamento familiar, imunização contra as principais doenças transmissiveis, prevenção e controle de endemias, educação em saúde e tratamento apropriado dos agravos mais comuns (WHO 1978).

A repercussão destas premissas internacionais coincidiu, no Brasil, com o reordenamento político e institucional do setor saúde, tendo como marco a promulgação da Constituição Federal (1988) e a Lei Orgânica da Saúde (1990) (BRASIL 1988; BRASIL 1990).

Os programas de atenção integral à saúde têm como pressuposto básico o desenvolvimento de ações dirigidas ao atendimento global das necessidades prioritárias dos grupos-alvo (MINISTÉRIO DA SAÚDE 1984a). A integralidade da assistência pressupõe, também, uma prática educativa que permeie todas as ações desenvolvidas, permitindo que a população se aproprie de conhecimentos necessários para a manutenção e recuperação da saúde (MINISTÉRIO DA SAÚDE 1984a; 1984c).

Para cumprir esses pressupostos, os programas de saúde materno-infantil deverão revitalizar os serviços de saúde, viabilizando para que todas as crianças e mães recebam atendimento precoce e de boa qualidade. Por outro lado, devem ser feitos esforços para que as famílias utilizem os serviços de saúde sempre que precisarem, sem impedimentos geográficos, econômicos ou culturais, o que parece estar distante da realidade de comunidades indígenas.

A eqüidade na utilização dos serviços de saúde, defendida como peça chave no processo de redução dos diferenciais de saúde, deve ser considerada um dos determinantes da saúde e doença na população, assim como fatores ambientais e comportamentais (BUSTAMANTE 1996). 
O programa de atenção integral à saúde da criança (PAISC), desenvolvido pelo Ministério da Saúde (1984a), é dirigido às crianças menores de cinco anos, com objetivo de reduzir a morbimortalidade, com a prestação de assistência aos agravos de maior prevalência na infância, através de cinco ações básicas: acompanhamento do crescimento e desenvolvimento infantil, incentivo ao aleitamento materno e orientação alimentar para o desmame, imunização, controle de doenças diarréicas e controle de infecç̃es respiratórias agudas. O programa preconiza no mínimo uma consulta mensal nos primeiros quatro meses, uma consulta trimestral dos cinco aos doze meses, uma consulta semestral dos treze aos vinte e quatro meses e uma consulta anual a partir dos vinte e cinco meses de idade (MINISTÉRIO DA SAÚDE 1984a).

O acompanhamento do crescimento e desenvolvimento é proposto como atividade integradora das outras ações previstas no programa, propiciando a identificação oportuna dos doentes ou com risco de adoecerem, favorecendo intervenções precoces e possibilitando maior alocação de recursos assistenciais aos grupos mais vulneráveis (MINISTÉRIO DA SAÚDE 1986a). Tem como instrumento básico, o cartão da criança, composto por dados de identificação, gráfico de crescimento, calendário vacinal e roteiro de acompanhamento do desenvolvimento (MINISTÉRIO DA SAÚDE 1992).

As atividades de incentivo ao aleitamento materno e orientação alimentar para o desmame têm como objetivo principal a reversão da tendência de desmame precoce, realizado através de práticas educativas quanto ao processo de lactação, suas vantagens e importância e quanto às técnicas de preparo da mama e de aleitamento; procedimentos capazes de tratarem ou reduzirem condições biológicas que poderão dificultar ou impedir o aleitamento; estruturação de alojamento conjunto nas maternidades; instruções para a introdução de outros alimentos no periodo de desmame e para a recuperação nutricional em nível ambulatorial (MINISTÉRIO DA SAÚDE 1984a, 1986b). Entre as ações que envolvem outros setores além da saúde estão as de controle do marketing dos sucedâneos do leite materno e similares e as de cumprimento das leis que contemplam a mulher trabalhadora que está amamentando (MINISTÉRIO DA SAÚDE 1986b, 1991).

As ações de imunização objetivam ampliar a cobertura vacinal entre os mais suscetíveis, através da aplicação das vacinas de rotina, valorização do cumprimento 
do calendário vacinal preconizado, captação precoce para a vacinação, busca de faltosos para complementação de doses de vacina e campanhas de imunização (MINISTÉRIO DA SAÚDE 1984c).

O controle das doenças diarréicas visa à diminuição dos agravos nutricionais e de mortalidade por desidratação, envolvendo atividades de ampla utilização e difusão da terapia de reidratação oral; utilização de reidratação endovenosa em situações especiais; orientação alimentar durante o episódio diarréico, no sentido da manutenção do aleitamento materno e de dietas adequadas energeticamente; normatização da definição de caso e uso de medicamentos em situações específicas; práticas educativas sobre saneamento e cuidados no manuseio de alimentos; controle de epidemias, estando esta última ação, vinculada diretamente ao serviço de vigilância epidemiológica (MINISTÉRIO DA SAÚDE 1985).

Ações de controle das infeções respiratórias agudas têm como objetivos: a redução da mortalidade por pneumonia em menores de um ano, a redução de casos graves e complicações, bem como do uso inadequado de antibióticos e outros medicamentos. Abrange, fundamentalmente, a normatização da definição de caso, baseada em observação clínica e da conduta específica a ser adotada (MINISTÉRIO DA SAÚDE 1987, 1991).

O programa de atenção integral à saúde da mulher (PAISM) tem como objetivos: o aumento da cobertura e concentração de consultas de atendimento prénatal; a melhoria da cobertura e qualidade da assistência ao parto, com diminuição do índice de cesarianas desnecessárias; aumento dos índices de aleitamento materno; implantação ou ampliação de atividades de identificação e controle de câncer cérvico-uterino e de mama; das doenças transmitidas sexualmente e de outras patologias de maior prevalência no grupo; desenvolvimento de atividades de regulação da fertilidade humana, através da contracepção ou correção de situaçães de infertilidade e prevenção de gravidez indesejada, evitando-se o aborto provocado (MINISTÉRIO DA SAÚDE 1984b).

Estudos descrevem a associação entre a assistência pré-natal e os resultados perinatais, particularmente $\mathrm{o}$ peso ao nascer $\mathrm{e}$ mortalidade perinatal. $\mathrm{O}$ comparecimento às consultas de pré-natal e o seu número total têm apresentado correlação positiva, significativa com o peso ao nascer e com a probabilidade da 
mulher ter um recém-nascido de peso normal (DONALDSON e BILLY 1984; KINCALD 1986).

A assistência clínico-ginecológica tem como instrumento o cartão da mulher e engloba procedimentos voltados para a identificação, diagnóstico e tratamento de patologias sistêmicas do aparelho reprodutivo. A avaliação do estado nutricional é mencionada como um dos procedimentos incluídos nesta assistência (MINISTÉRIO DA SAÚDE 1984b).

A assistência pré-natal é dirigida para a promoção da saúde e identificação precoce de situações de risco para a gestante ou o concepto, reúne os procedimentos de anamnese e exame clínico inicial, acompanhamento periódico e sistemático, orientações tanto em relação ao processo de lactação e sua importância, quanto a futuras alternativas de contracepção (MINISTÉRIO DA SAÚDE 1984b). Tem como instrumento o cartão da gestante, que contempla o índice peso para estatura, para a idade gestacional como indicador do estado nutricional, sendo operacionalizado através do gráfico de Rosso (ROSSO 1985).

A assistência ao parto e ao puerpério imediato engloba ações de anamnese e exame clínico-obstétrico, buscando detectar fatores que possam trazer complicações ao parto ou puerpério; acompanhamento sistemático dos períodos de dilatação, expulsão e dequitadura; assistência ao recém-nascido; estímulo ao aleitamento materno, se possível ainda na sala de parto; implementação do alojamento conjunto nas maternidades; melhoria da qualidade da assistência ao parto hospitalar e ao parto domiciliar - através da capacitação da equipe de saúde e parteiras, fornecimento de material de parto e estabelecimento de mecanismos de referência; assistência ao puerpério imediato, com supervisão continuada; orientações sobre alternativas de contracepção; incentivo à manutenção da amamentação, manuseio de técnicas de relactação e tratamento de doenças mamárias (MINISTÉRIO DA SAÚDE 1984b; OSIS et al., 1993). Aqui também é citada a avaliação nutricional como procedimento inerente a essa assistência, mas sem formalização de indicadores para tal.

O PAISM considera como clientes assistidas durante o pré-natal aquelas que comparecem a um mínimo de seis consultas no decorrer da gestação. Conforme as normas de pré-natal do Ministério da Saúde, o intervalo entre duas consultas não deve ultrapassar oito semanas (MINISTÉRIO DA SAÚDE 1988). 
Considerando o cuidado infantil como um dos elementos do processo saúdedoença, e que a assistência ao binômio mãe-criança é prioritário no conjunto de ações de saúde, essa pesquisa também obteve informações referentes à utilização de ações básicas de saúde vinculadas ao PAISC E PAISM, como a assistência pré-natal, assistência ao parto, acompanhamento do crescimento infantil, controle de doenças diarréicas, incentivo ao aleitamento materno e imunização, no sentido de identificar e avaliar ações especificas do setor saúde em nível local.

\subsection{Assistência à Saúde Indígena}

Com a criação do Serviço de Proteção aos Índios (SPI), em 1910, não se instituiu uma forma de prestação de serviços sistemáticos e de qualidade à população. O amplo programa assistencial do SPI não se tornou realidade, tendo como atividade de maior desempenho a de "pacificar índios hostis". O positivismo e os ideais humanitários de Rondon e sua equipe, não eram suficientes para dar resposta imediata ao complexo problema que se estabelecia sempre que um grupo indígena entrava em contato com representantes da sociedade não indígena. A pacificação representava a eliminação de um grave obstáculo à ocupação de terras. Nesse sentido, o SPI foi um órgão que não atendeu aos interesses e necessidades das comunidades indígenas (GOMES 1988).

BALDUS (1927) descreve as relações entre índios e não índios na década de 20, destacando a política do extermínio: "Não se espera nenhum resultado útil das comissões oficiais para a proteção aos índios, muitas vezes seria melhor chamá-las comissões para o assassinato de índios. Desde que um acampamento é militarmente ocupado vêem-se os índios forçados a fazer qualquer trabalho ou pelo menos deixar-se fotografar e os que não obedecem imediatamente são fuzilados. Mais tarde trocam-se as fotografias na capital por título e glória" (p.30).

Segundo RIBEIRO (1970), o processo de "pacificação das tribos hostis" ocasionou a disseminação da fome e de doenças, tornando os índios parte do grupo mais miserável dos segmentos marginais da sociedade.

As informações iniciais sobre condições de saúde vieram de relatos de missionários e de médicos participantes de expedições. Somente na década de 50 , criou-se o Serviço de Unidades Sanitárias Aéreas (SUSA), proposto por Noel Nutels 
e que objetivava ações de saúde aos índios e às populações rurais de dificil acesso (COSTA 1987).

O trabalho de Noel Nutels junto aos índios teve início a partir de sua participação como médico na Expedição Roncador-Xingu, organizada no Governo Getúlio Vargas, com o objetivo de desbravar terras ainda desconhecidas entre o Brasil Central e a Amazônia (COSTA 1987).

Em 1952, Nutels apresentou um projeto de implantação de unidades volantes para atendimento à saúde em áreas indígenas, onde defendia a prevenção de doenças infecciosas. Esse projeto teve grande repercussão junto aos profissionais do Serviço Nacional de Tuberculose, realizando algumas viagens ao Araguaia e Alto Xingu realizando abreugrafias e vacinações, porém em caráter voluntário, contando com recursos obtidos através de contatos pessoais. Somente em 1956 foi institucionalizado o SUSA, estando ligado administrativamente ao Serviço Nacional de Tuberculose, apesar de não restringir suas ações ao diagnóstico e controle da tuberculose. Contou também com apoio da Força Aérea Brasileira (FAB) que criou o Correio Aéreo Sanitário, transportando material e as equipes de saúde até o ano de 1964 (NUTELS 1952).

Após a criação do SUSA, o trabalho ampliou-se para os grupos indígenas do sul de Mato Grosso, especialmente entre os índios Terena e Kadiweu. No final de 1963, Noel Nutels foi nomeado diretor do SPI, época em que o órgão já estava com graves problemas internos e extremamente decadente. Nutels só permaneceria seis meses como diretor dos SPI, o golpe militar de 1964 interromperia sua gestão (NUTELS 1969).

$\mathrm{Na}$ década de 60, muitos funcionários do SPI foram acusados de corrupção, apropriação indevida de bens e terras indígenas, maltratos e prisão de índios em cárceres privados e muitos outros crimes foram investigados por uma comissão parlamentar de inquérito, nomeada pelo Ministro do Interior, General Albuquerque Lima, que representava, na época, um setor nacionalista das forças armadas. As denúncias foram comprovadas por relatórios que documentavam as atrocidades e violências, inclusive a introdução deliberada de doenças como: varíola, gripe, tuberculose e sarampo entre os grupos indígenas. Os processos foram arquivados, não havendo registro sobre funcionários do SPI punidos por seus crimes. Os fatos ficaram conhecidos no exterior, onde tem início uma campanha contra a política 
indigenista brasileira (MOONEN 1983). Diante disto, o governo brasileiro extinguiu o SPI que, em dezembro de 1967, foi substituído pela FUNAI, através da Lei ${ }^{\circ}{ }^{\circ}$ 5371 , com poderes de "representação ou assistência jurídica inerente ao regime tutelar do índio" (BRASIL 1967).

Com a FUNAI, os profissionais do SUSA propuseram a formação de equipes volantes de saúde em cada Delegacia Regional, a fim de que prestassem serviços aos grupos indígenas, com isso, passariam a trabalhar especificamente no controle da tuberculose e a FUNAI assumiria a responsabilidade da execução da assistência médica. As equipes volantes formadas pautaram-se na assistência individual aos índios. Os profissionais de saúde residiam nas capitais, sede das Delegacias Regionais. Realizavam viagens esporádicas, onde prestavam atendimento médico simples e promoviam a remoção dos casos graves para hospitais da região. Coerente com a administração do órgão, os recursos financeiros da divisão de saúde eram absorvidos com salários, transporte e diárias dos profissionais e a remoção de doentes (COSTA 1987).

O trabalho do SUSA, posteriormente denominado de Unidade de Atendimento Especial, também sofreu mudanças em função da diminuição das verbas e da falta de apoio institucional do Ministério da Saúde e FUNAI, sendo levado a um lento processo de extinção (COSTA 1987).

Em 1986, é realizada a I Conferência Nacional de Proteção à Saúde do Índio, conforme deliberação da VII Conferência Nacional de Saúde, onde ficaram estabelecidas as bases para um subsistema específico de atenção à saúde indígena, destacando-se a criação de uma agência estatal, vinculada ao Ministério da Saúde, com finalidade exclusiva de atendimento à saúde indigena (MINISTÉRIO DA SAÚDE 1987). Esse seria o ponto de partida para a criação de um sistema regionalizado e hierarquizado de assistência à saúde. Com a criação do Sistema Único de Saúde (SUS), fica garantido o direito de atenção integral e diferenciada à saúde, justificada pela vulnerabilidade e especificidade étnica, o que efetivamente não se concretizou, devido à precariedade das ações de saúde desenvolvidas ao longo dos anos. Em 1991 (Lei no 2.057 e Decreto Presidencial n ${ }^{\circ} 23$, de 4/2/1991), o Ministério da Saúde assume a responsabilidade pela coordenação das ações de saúde para os povos indígenas, fazendo referência ao Distrito Sanitário Especial Indígena, 
como forma de organização do subsistema de atenção à saúde do índio (FUNASA 1997).

A II Conferência Nacional de Proteção à Saúde dos Povos Indígenas (1993) preconizou, em seus princípios e diretrizes para o modelo assistencial, que a saúde indígena seja responsabilidade do Governo Federal, sem excluir as contribuições que possam advir dos Estados e municípios, bem como de outras organizações não governamentais. Definiu ainda a incorporação de um subsistema diferenciado de saúde, com base nos Distritos Sanitários Especiais Indígenas, com autonomia de gestão administrativa, orçamentária e financeira (MNISTÉRIO DA SAÚDE 1993).

Em maio de 1994 (Decreto Presidencial no 1141 de 19/5/1994), a gestão política da saúde indígena passa para a FUNAI, sendo instituída a Comissão Intersetorial de Saúde do Índio (CISI), com responsabilidade total sobre a saúde indígena. Em outubro do mesmo ano, a CISI aprova um Modelo de Atenção Integral à Saúde do Índio, onde estabelece a divisão de atribuições entre a FUNAI e o Ministério da Saúde - Fundação Nacional de Saúde (FUNASA). À FUNAI competia a assistência direta aos índios, reservando-se à FUNASA as ações de imunização, saneamento básico, desenvolvimento de recursos humanos e controle de endemias (FUNASA 1997). Essa medida significava descontinuidade política e as soluções propostas neste modelo não se concretizaram, ocorrendo ações fragmentadas entre as instituições, sem a participação dos povos indígenas no processo.

Os inúmeros problemas referentes a recursos humanos, materiais e financeiros para custeio dos projetos e a não execução das atividades previstas com relação à capacitação de recursos humanos, a ausência de ações de saneamento básico e a devolução de recursos já liberados, contribuíram com o avanço do reconhecimento dos direitos dos povos indígenas, através de pressões exercidas por agências internacionais (WEISS 1998).

Nas discussões sobre a democratização das ações, a saúde e a doença em comunidades indígenas vem sendo abordada no sentido de conhecer seus determinantes e adotar modelos diferenciados de atuação. Essas discussões têm defendido a proposta de implantação de modelos diferenciados com base nas diretrizes do Sistema Único de Saúde (SUS) e nas peculiaridades das diferentes etnias como a situação de contato, dinâmica do perfil epidemiológico, mudanças das 
práticas tradicionais de saúde, situação geográfica e a implicação na continuidade das ações de saúde (WEISS 1998).

Em agosto de 1999, o Ministério da Saúde, por intermédio da FUNASA, assume a responsabilidade de reestruturar o subsistema de atenção à saúde indígena, em parceria com municípios e organizações não-governamentais, através de convênios. A proposta contempla a organização dos serviços de saúde na forma de trinta e quatro Distritos Sanitários Especiais Indígenas (DSEI), como uma base territorial e populacional sob responsabilidade sanitária identificada, reunindo o conjunto de aç̃oes de saúde necessárias à atenção básica, articulado com a rede do SUS, com autonomia administrativa e financeira, composta por equipe necessária para executar suas ações e com controle social através dos Conselhos Distritais (FUNASA 2001).

Em Mato Grosso do Sul, foi implantado um (1) DSEI com sede em Campo Grande, para atender seis (6) etnias distribuídas em cinqüenta e cinco aldeias (55), pertencentes a vinte e cinco (25) municípios. A execução das açães de atenção básica estão sendo realizadas por dezessete equipes, selecionadas e contratadas pela organização não-governamental Missão Caiuá (FUNASA 2001).

A precariedade do diálogo e da participação indigena no planejamento $\mathrm{e}$ organização dos serviços, somada às dificuldades operacionais e à elevada rotatividade dos profissionais de saúde nas equipes (especialmente profissionais médicos), têm provocado reflexos importantes na implementação do distrito local.

Esta proposta está sendo implementada sob críticas de organizações não-governamentais e pesquisadores, que avaliam como insuficiente a implantação de um distrito sanitário para o atendimento das especificidades étnicas, culturais e geográficas dos povos indígenas, bem como, contrários a ausência do controle social pleno (CIMI 2000). 


\section{OBJETIVOS}

\subsection{Objetivo Geral}

Avaliar as condições de saúde e nutrição de crianças indígenas Terena.

\subsection{Objetivos Específicos}

Descrever as condições socioeconômicas, demográficas e ambientais das familias.

Identificar e avaliar a utilização dos serviços de assistência à saúde materno-infantil.

Estimar a prevalência de eventos mórbidos e internações hospitalares.

Descrever a prática alimentar, identificando as refeições realizadas, os alimentos e preparações culinárias que compõem a dieta e as quantidades ingeridas.

Avaliar o consumo alimentar em termos de energia, macronutrientes (carboidratos, proteínas e lipídeos) e micronutrientes (cálcio, ferro, retinol e vitamina C).

Identificar a freqüência do aleitamento materno.

Avaliar as condições antropométricas das crianças. 


\section{MATERIAL E MÉTODO}

Estudo epidemiológico de observação transversal, realizado no Estado de Mato Grosso do Sul, em duas áreas, denominadas Buriti (Aldeia Buriti, Córrego do Meio e Água Azul) e Buritizinho (Aldeia Tereré), pertencentes aos municípios de Dois Irmãos do Buriti e Sidrolândia, distantes respectivamente a 100 e $65 \mathrm{~km}$ da

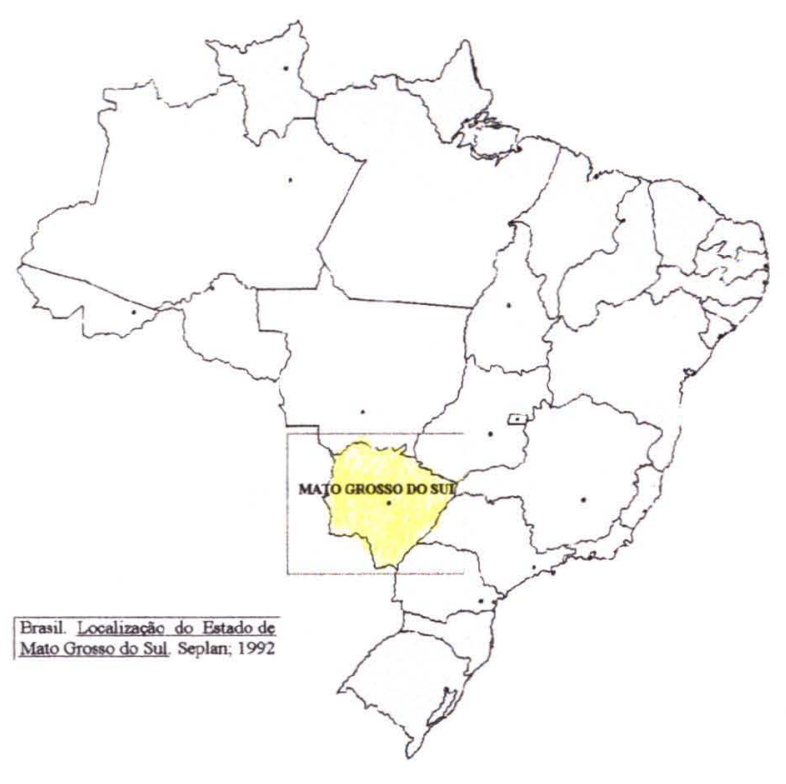
capital do Estado (Figuras 1 e 2).

Figura 1. Localização do Estado de Mato Grosso do Sul.

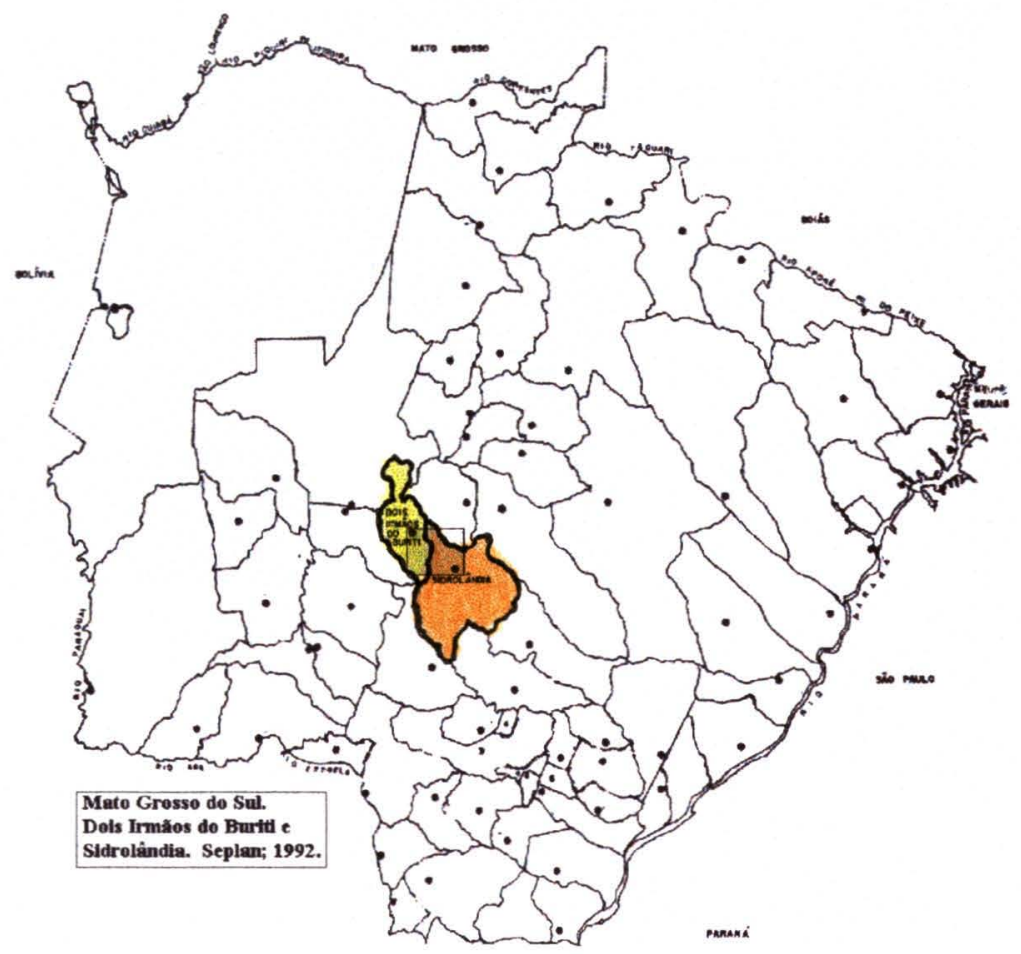

Figura 2. Estado de Mato Grosso do Sul com localização dos municípios de Dois Irmãos do Buriti e Sidrolândia. 
A área indígena Buriti, habitada desde 1920 por famílias Terena, foi demarcada em 23 de dezembro de 1927, com 2.090 hectares, sendo instalada pelo Serviço de Proteção aos Índios (SPI) em 1928 e homologada em 1991, onde se localizam as Aldeias Buriti, Água Azul e Córrego do Meio (Figura 3).

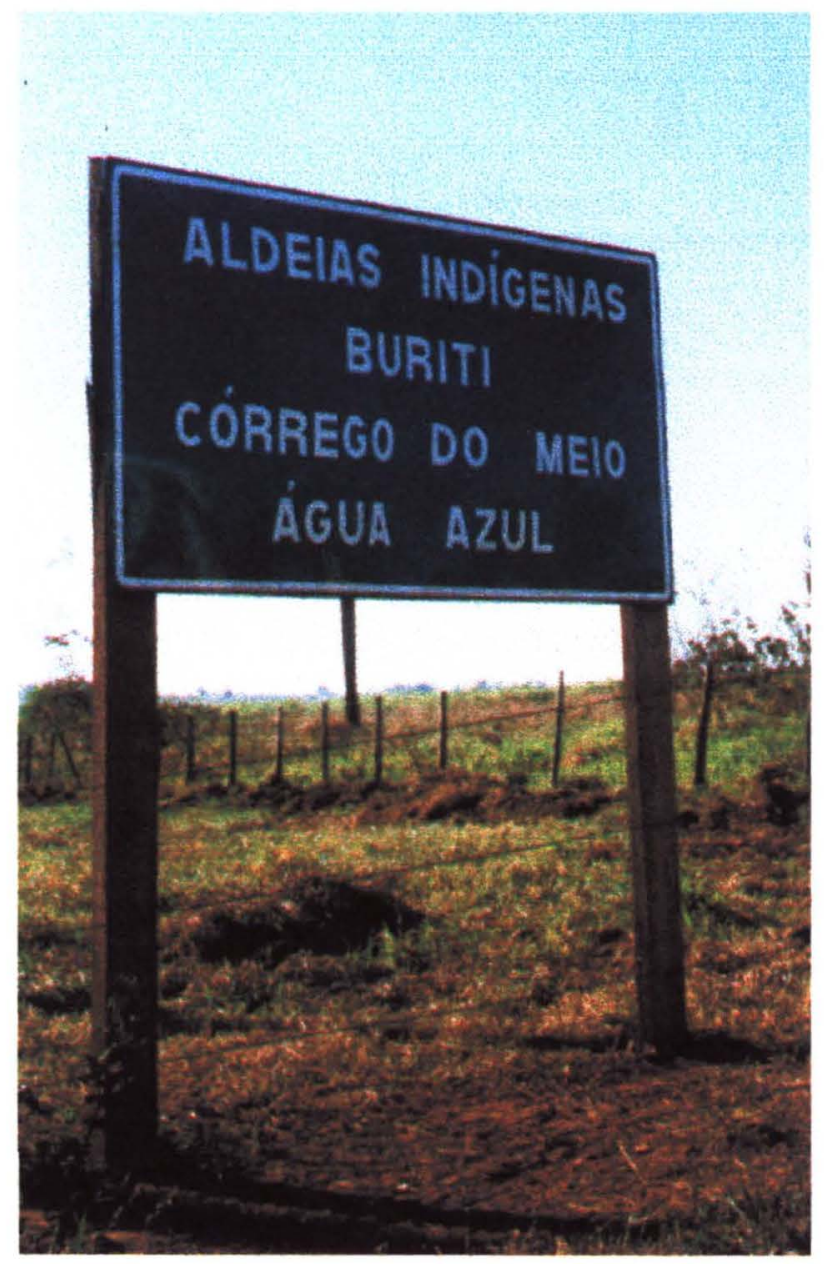

A área indígena Buritizinho, situada atualmente no perímetro urbano do município de Sidrolândia, habitada por famílias Terena desde 1942, foi identificada em 1982 e demarcada em 9 de julho de 1984 com 10 hectares, denominada Aldeia Tereré. Relatos de idosos descrevem a vinda de cinco famílias provenientes das Aldeias Buriti e Córrego do Meio, para a área Buritizinho, à procura de trabalho, saúde e escola para os filhos e liderados pelo xamã (Koixomuneti).

Figura 3. Placa de identificação na rodovia MS 162

\subsection{População do Estudo}

Inicialmente foram identificadas 358 crianças pertencentes a 215 famílias, porém, ocorreram recusas de participação, correspondentes a 3 famílias (quatro crianças). 


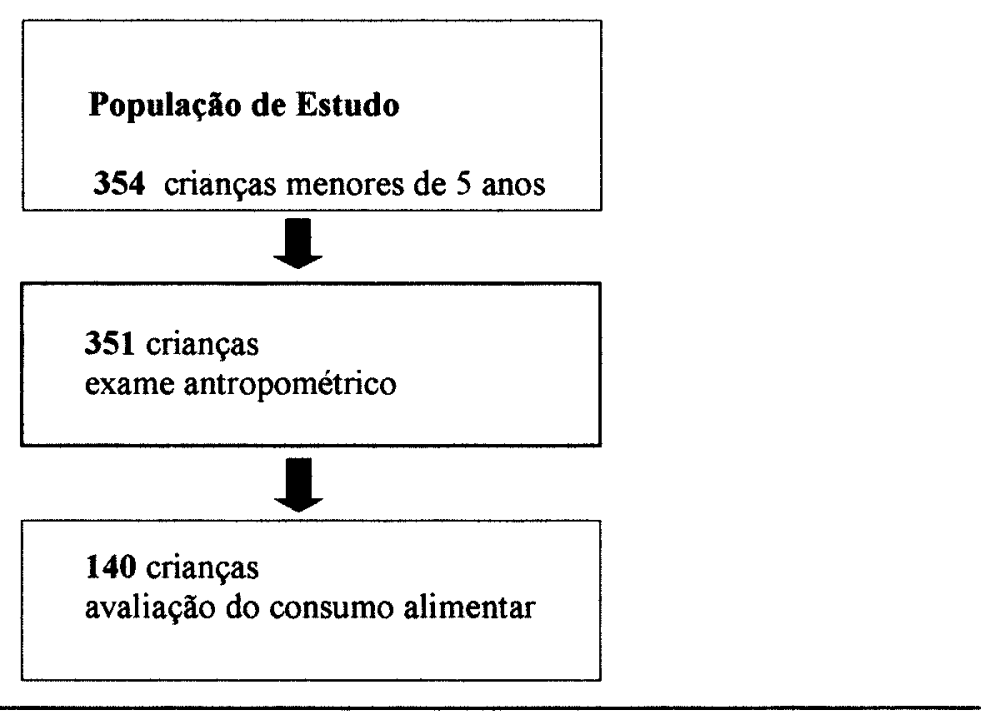

Figura 4. Fluxograma descritivo da população do estudo

Foram avaliadas 354 crianças de zero a cinqüenta e nove meses de idade, de ambos os sexos, que correspondem a $98,9 \%$ da população menor de cinco anos residentes nas áreas de estudo, pertencentes a 212 famílias.

Das 354 crianças estudadas, 3 não foram avaliadas antropometricamente, pois encontravam-se ausentes no período de obtenção das medidas. Para análise do consumo alimentar foi selecionada uma amostra aleatória, mediante sorteio de 35 crianças de cada aldeia, totalizando 140 crianças de famílias distintas (Figura 4).

\subsection{Variáveis}

\subsubsection{Socioeconômicas, Demográficas e Ambientais}

A renda familiar per capita foi obtida somando-se a renda de cada morador que contribuía no conjunto das despesas da casa, incluindo aposentadoria, pensão, doações e salários e dividindo-se o resultado pelo número de moradores.

O valor obtido foi transformado em salários mínimos ( $R \$ 136,00$ - cento e trinta e seis reais), à época do estudo. A escolaridade dos pais foi classificada em anos de estudo, identificada com a adoção das seguintes categorias: sem escolaridade; 1 a 4 anos; 5 a 8 anos e mais de 8 anos de estudo. 
Foi identificada a ocupação principal do chefe da família. Como ocupação principal entendeu-se a atividade, cargo ou função exercido durante a maior parte dos 12 meses anteriores à pesquisa.

Com relação à utilização da terra disponível, foi identificada a existência de roças, pomares e hortas, destino de produtos cultivados, criação de animais, prática de caça e pesca e coleta de frutos silvestres.

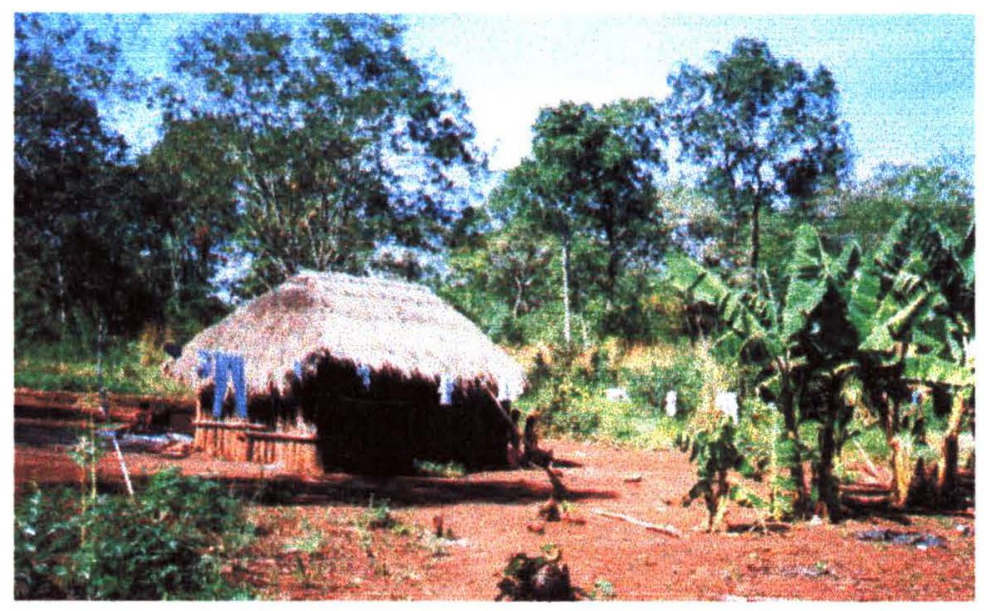

A condição de
saneamento do meio foi
identificada a partir das
características do
abastecimento de água,
existência de sanitário e
escoamento de dejetos e
lixo.

Figura 5. Habitação Terena

A título de caracterização das condições da habitação foram identificados material de construção como o revestimento do piso, material de cobertura e paredes, fonte de iluminação, número de cômodos utilizados para dormir e presença de equipamentos domésticos como geladeira, freezer, fogão, televisão, rádio e aparelho de som (Figura 5).

A densidade familiar foi obtida pelo número de pessoas residentes no domicílio, sendo consideradas as pessoas moradoras presentes ou ausentes temporariamente no dia da pesquisa.

Foi identificado o número de fillhos nascidos vivos, número de filhos vivos no período estudado, número de abortos e natimortos. A idade foi determinada a partir da data de nascimento e contada em número de vezes que a mesma se repetiu nos meses subseqüentes, até a data da obtenção do peso e estatura, sendo considerado meses completos para as crianças e anos completos para os pais. 


\subsubsection{Variáveis Antropométricas}

Foram obtidas medidas de peso, estatura e circunferência braquial (Figura 6), sendo utilizados os índices peso/idade, estatura/idade e peso/estatura, para avaliação nutricional, com ponto de corte de -2 e +2 z-escores, e padrão de referência NCHS/WHO (NCHS 1977).

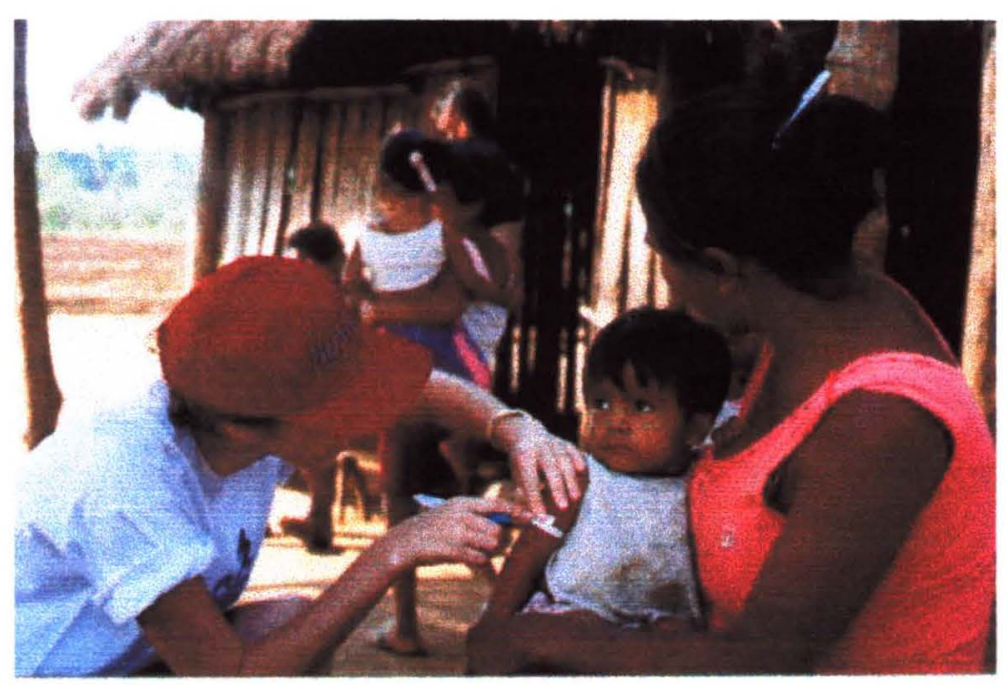

Para análise da circunferência braquial, -2 e +2 desvios padrão, da referência NHANES I e II (WHO 1995).

Figura 6. Obtenção da circunferência braquial.

\subsubsection{Assistência à Saúde Materno-Infantil}

Foi identificada a freqüência ao serviço de pré-natal, sendo definido como todo o acompanhamento periódico e programado da gestante com objetivo de prevenir possíveis complicações da gravidez, parto e pós-parto, bem como preparar a futura mãe para os cuidados com a criança.

Foram ainda investigados o tipo de parto e assistência recebida no nascimento da criança. Foi considerado como parto normal todo aquele em que a criança nasceu por via vaginal, não importando se houve ou não o uso de fórceps, e, parto cirúrgico, o parto cesariano. A idade gestacional foi obtida em meses completos de gestação, sendo considerado gestação pré-termo as de duração inferior a 9 meses; gestação a termo foram mencionadas as de 9 meses; e pós-termo com duração de 10 meses ou mais. 
Foi identificada a cobertura vacinal das crianças na faixa etária de 12 a 59 meses de vida, sendo considerado dados confirmados através da carteira de vacina, senha de campanha ou cicatriz vacinal.

$\mathrm{Na}$ avaliação da freqüência ao serviço de acompanhamento do crescimento infantil, foram considerados a realização da pesagem periódica e o registro do peso no cartão da criança.

\subsubsection{Peso ao Nascer}

O peso ao nascer foi obtido mediante consulta ao cartão da criança ou documento fornecido pelo local de nascimento. Foram obtidos os valores de peso ao nascer de 192 crianças $(54,2 \%)$, não sendo consideradas informações sem registro. Muitas crianças não haviam sido pesadas, por terem nascido no domicílio. Foram utilizadas as seguintes estratificações de peso: $\leq 2500 \mathrm{~g} ; 2501-3500 ; 3501-4000 \mathrm{~g}$; $>4000 \mathrm{~g}$.

\subsubsection{Morbidade e Internações Hospitalares}

A ocorrência de doenças foi avaliada pela morbidade referida pelos pais no período da entrevista, a ocorrência de diarréia e pelas internações hospitalares. A diarréia era referente ao dia da entrevista e aos últimos quinze dias anteriores, sendo considerada diarréia a presença de três ou mais episódios com fezes de consistência amolecida ou líquida em um periodo de 24 horas. A pesquisa de antecedentes de internações hospitalares referia-se aos últimos seis meses, sendo considerada hospitalização a permanência em ambiente hospitalar por um período igual ou superior a 24 horas.

\subsubsection{Consumo Alimentar}

A identificação e avaliação da dieta da criança foi realizada por meio do método recordatório, aplicado em um dia, possibilitando estimar a ingestão de 
alimentos ou nutrientes consumidos por um período de 24 horas, sendo avaliada a ingestão calórica e composição da dieta em proteínas, carboidratos, lipídios, cálcio, ferro, retinol e vitamina C (Figura 7).

Os dados foram revisados e avaliados pelo software Virtual Nutri, com análises do valor quantitativo e qualitativo da dieta, bem como a adequação da mesma (PHILIPPI et al., 1996). O consumo de bocaiúva e araticum foi analisado de acordo com tabela de composição de alimentos regionais (HIANE et al., 1990, 1992).

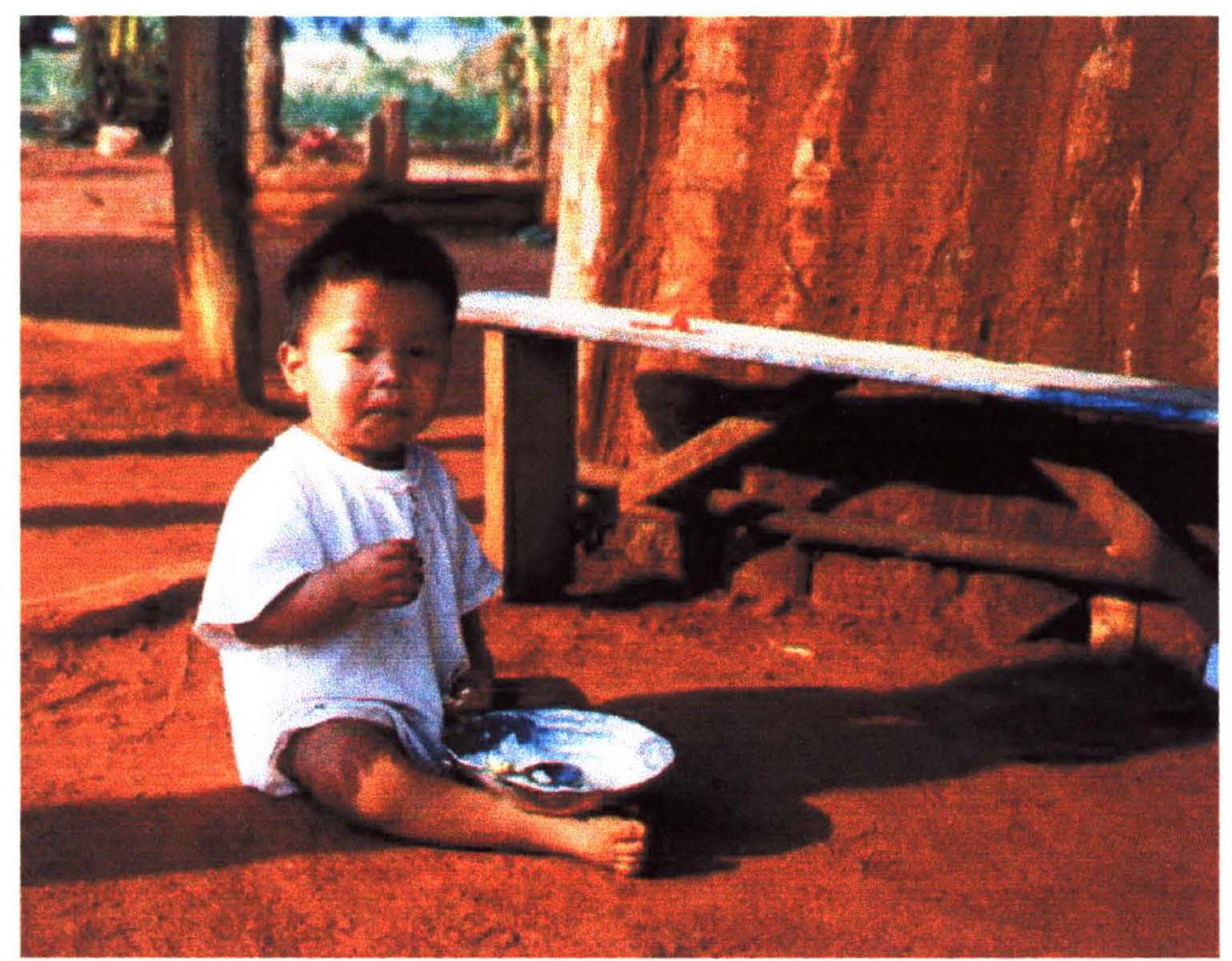

Figura 7. Criança recebendo a primeira refeição do dia.

As médias de consumo de energia, proteínas, ferro, retinol e vitamina $\mathrm{C}$ foram comparadas às recomendações para a população sadia dos Estados Unidos (RDA 1989), sendo estudadas com relação ao sexo, idade e aldeias. Para o consumo de cálcio utilizaram-se as recomendações de ingestões dietéticas, denominadas Dietary Reference Intakes (DRI 1997). Dietas que não atingiram as recomendações foram interpretadas como dietas de risco. 
A avaliação qualitativa do consumo alimentar da família foi obtida através do questionário de freqüência, que consistia de uma lista de alimentos agrupados segundo a composição nutricional e com uma seção de respostas sobre a freqüência de consumo de cada alimento. Os alimentos incluídos no questionário correspondem aos mais comumente consumidos pela população rural da região e comunidade indígena urbana. Foi ainda investigada a produção de alimentos na terra disponível, a prática da caça, pesca e coleta de frutos silvestres.

\subsubsection{Aleitamento Materno}

Foram estudadas crianças de 0 a 6 meses de idade, obtendo-se informações da mãe sobre a forma e horários de oferecimento, tipo de aleitamento, momento de desmame e orientações recebidas sobre aleitamento materno (Figura 8).

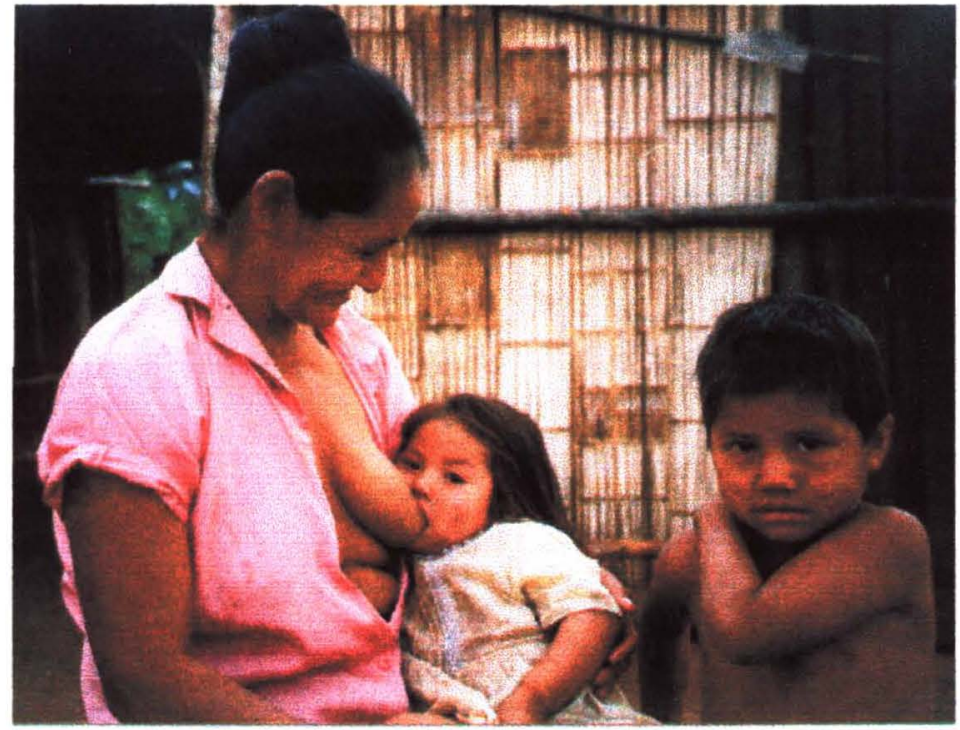

Figura 8. A alegria de amamentar

Nas crianças maiores de 6 meses, foi estudada a presença da amamentação na época da entrevista, através da análise da dieta infantil. Na categoria aleitamento materno exclusivo, quando a criança recebia o leite materno como única fonte de alimento, diretamente da mama ou extraído. Aleitamento materno predominante com crianças alimentadas ao seio e que recebiam também água, chá, suco de frutas e solução para hidratação oral. Aleitamento materno misto com crianças alimentadas com leite materno, além de alimentos sólidos ou semi-sólidos, incluindo, obrigatoriamente, outros tipos de leite e alimentação artificial quando a criança já havia sido desmamada (OPAS. OMS 1991). 


\subsection{Coleta de Dados}

Participou do estudo equipe multidisciplinar de 16 elementos, incluindo nutricionistas, estatísticos, educadores, alunos de graduação em medicina e nutrição, agentes indígenas de saúde e motoristas.

Durante doze meses, anteriores à coleta de dados, foram realizadas pela autora seis visitas às comunidades, a fim de se deixar conhecer. Nessas visitas, o silêncio e a observação faziam parte de um revelar cauteloso, até a obtenção da autorização para ouvir os relatos de cada família. Os índios Terena enfatizam a audição, estando o ouvir ligado à compreensão e reelaboração de conhecimentos. Esse contato prévio foi, em parte, responsável pelo acolhimento do trabalho e pela qualidade das informações obtidas.

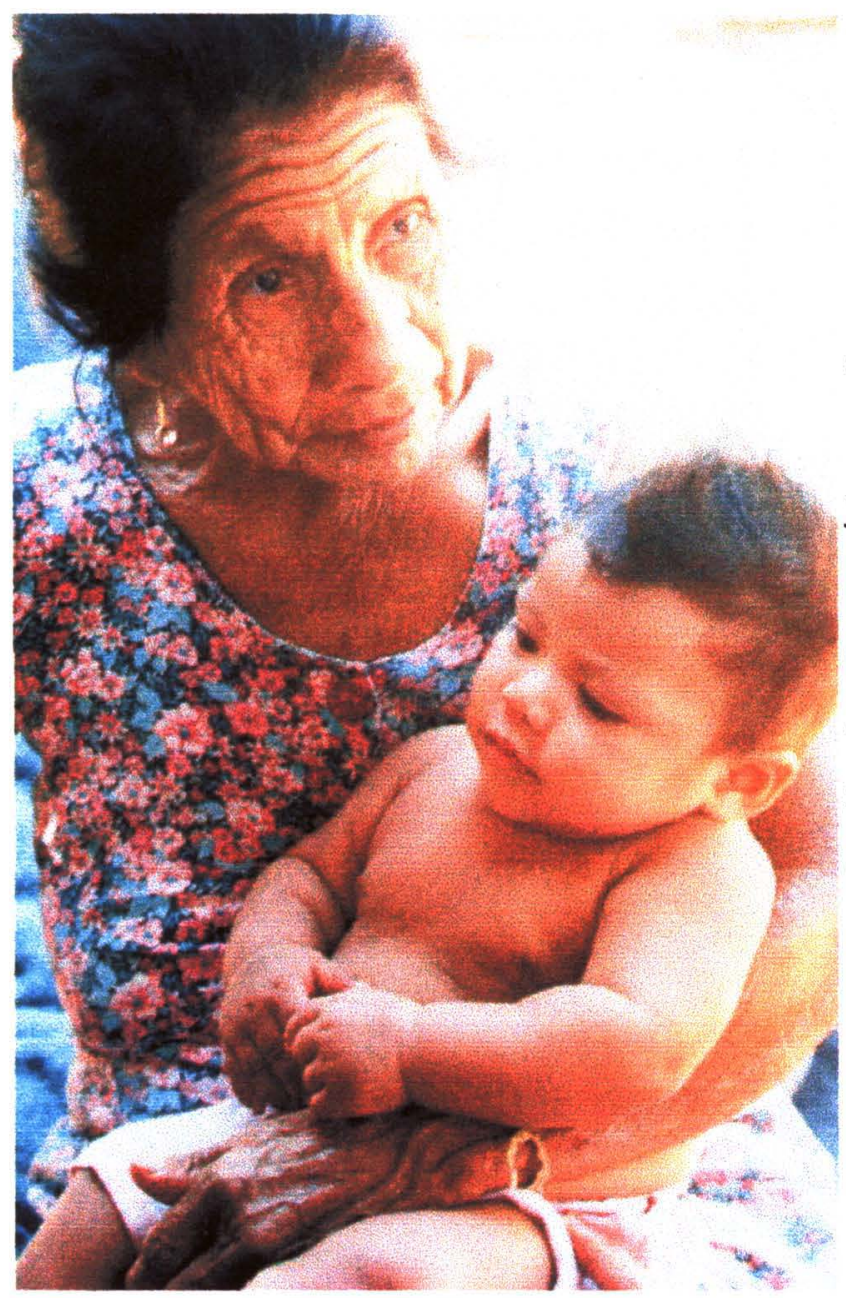

A coleta de dados foi efetuada entre julho a dezembro de 1999, com realização da entrevista junto aos pais e avós (Figura 9 e 10). Os avós são elementos ativos e participantes do cuidado infantil desde o nascimento, além de responsáveis pela transmissão cultural junto às novas gerações.

Figura 9. Avó apresenta seu neto 
Os idosos comunicam-se no dialeto Terena e em português. Quanto aos pais das crianças, poucos falam o idioma nativo, mas todos lutam pela alfabetização bilíngüe para seus filhos na escola da comunidade. As perguntas eram feitas primeiramente ao homem, cabendo a ele a decisão sobre a participação feminina na entrevista, uma vez que entre os Terena a fala é atributo dos homens.

As respostas eram registradas em formulário próprio (Anexo 6) e o ritmo da entrevista era estabelecido pela família, podendo durar de 1 a 4 horas, com interrupções para o silêncio ou para a realização de alguma atividade na casa ou fora dela, como por exemplo, ralar mandioca, cobrir a casa, fazer farinha, colher frutos, lavar roupa ou tomar banho de rio, o que representava maior conhecimento e confiança entre entrevistador e entrevistado.

O trabalho de campo foi coordenado pela autora e participaram 5 entrevistadores e 5 guias indígenas. Todos os domicílios foram visitados por dois entrevistadores e um guia indígena, especialmente indicado pelo cacique, para o acompanhamento dos trabalhos. Os guias eram agentes de saúde e contribuíram para prestar esclarecimentos sobre a dinâmica da comunidade, valores culturais, práticas tradicionais de saúde e auxiliar na adequação da linguagem e comportamento da equipe em campo.

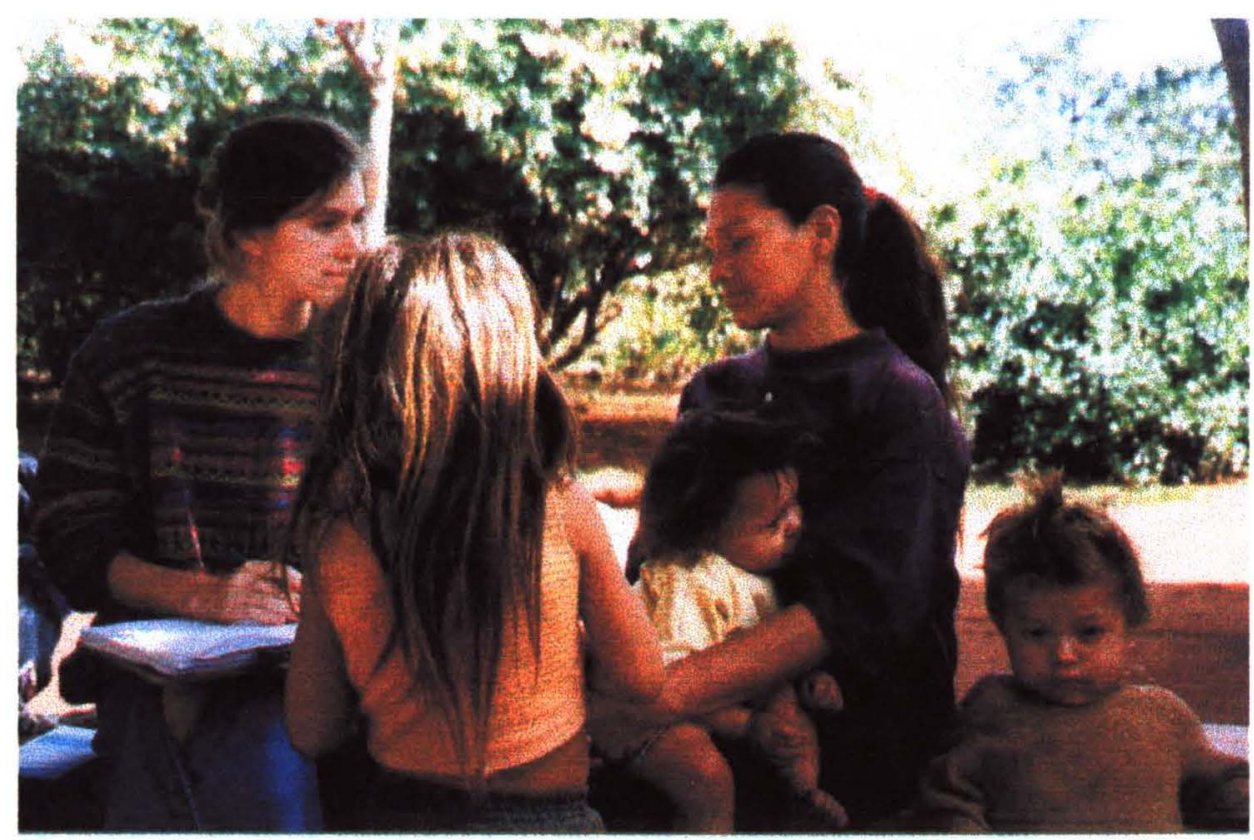

Figura 10. Realização de uma entrevista. 
Os entrevistadores receberam treinamento específico, com descrição detalhada da pesquisa, da técnica de entrevista, utilização de formulários, padronização da antropometria, localização dos domicílios, exercícios de simulação de entrevistas e estudo piloto com todas as atividades de campo previstas.

Foram instaladas unidades de apoio operacional no Departamento de Tecnologia de Alimentos e Saúde Pública da Universidade Federal de Mato Grosso do Sul e no Centro Cultural Francisco de Assis, município de Sidrolândia, a 65 Km de Campo Grande.

Após a análise dos dados, novas visitas foram feitas às comunidades, onde foram realizadas reuniões com as famílias e lideranças. Para os caciques foram elaborados relatórios com descrição detalhada dos resultados obtidos e, para os grupos de discussão (pais, professores e agentes de saúde), foram confeccionados cartazes ilustrados com desenhos e fotos, representativos da situação observada em cada comunidade.

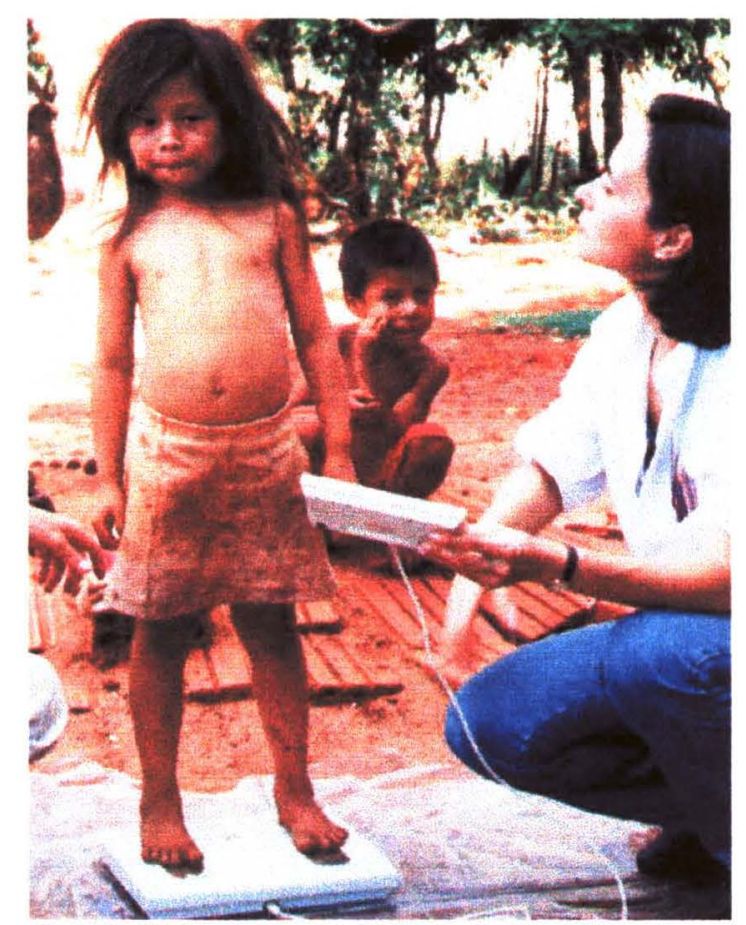

As medidas antropométricas foram obtidas pela autora e auxiliada por entrevistadores devidamente treinados (Figura 11). A técnica de antropometria adotada neste estudo foi baseada em recomendações da Organização Mundial de Saúde e do documento Anthropometric Standardization Reference Manual (WHO 1995; LOHMAN et al., 1988).

Figura 11. Preparação para a pesagem.

Foram realizadas as medidas antropométricas de peso, estatura, e circunferência braquial. Na medição do comprimento de crianças abaixo de 24 
meses, foi utilizado antropômetro de madeira, tipo horizontal, com régua graduada em centímetros, construído especialmente para a pesquisa. A medida foi realizada por dois antropometristas, estando a criança deitada de costas na prancha horizontal, com a cabeça posicionada no Plano de Frankfurt e alinhada perpendicularmente ao plano da prancha (CAMERON 1984).

Para obtenção da estatura da mãe e crianças acima de 24 meses, foi utilizado antropômetro digital eletrônico, com o indivíduo descalço, pernas paralelas, braços ao longo do corpo e cabeça posicionada no Plano de Frankfurt (CAMERON 1984). As medidas foram registradas em milímetros sem arredondamento.

As crianças menores de 24 meses foram pesadas sem roupa, no colo da mãe ou responsável. Logo a seguir, era pesada a mãe sem a criança, para, por diferença, obter-se o peso da criança. As mães e as crianças maiores de 24 meses foram avaliadas em balança digital eletrônica, estando descalças, vestindo roupas leves, com o peso distribuído em ambos os pés.

A medida do ponto médio do braço foi realizada no braço direito, sendo a metade da distância entre o processo acromial e o olécrano. No ponto médio foi realizada a medida de circunferência do braço, com fita métrica inelástica, com divisão de $0,1 \mathrm{~cm}$, em plano horizontal.

$\mathrm{O}$ inquérito alimentar foi aplicado junto aos pais, pela autora da pesquisa e entrevistadores treinados. O consumo alimentar foi avaliado em nível individual, com identificação da dieta da criança, realizada por meio do método recordatório de 24 horas, referente ao dia anterior à pesquisa, isto é, desde a primeira refeição da manhã até a última refeição da noite, sendo verificado o número e tipo de refeições realizadas, as preparações elaboradas e os alimentos consumidos. As informações foram obtidas em medidas caseiras e, posteriormente, convertidas em pesos e volumes. Como instrumento auxiliar no dimensionamento das porções consumidas foram utilizados utensílios usuais da área em estudo, como copos, canecas, colheres, conchas e pratos.

A avaliação da frequeência do consumo de alimentos foi realizado com formulário específico, contendo opções de: por dia, semana, mês e, ainda, nunca ou quase nunca (Anexo 6). 
Para avaliar o consumo de frutas e hortaliças incluíram-se as opções de: só na estação ou só no período da colheita. A lista de alimentos do questionário de frequêencia foi construída a partir dos dados obtidos no estudo piloto.

\subsection{Estudo Piloto}

Para obter um diagnóstico inicial das comunidades e testar os instrumentos de coleta de dados, foram realizadas visitas às áreas indigenas e um estudo piloto em uma comunidade indígena urbana, no município de Campo Grande, Mato Grosso do Sul. Nas 63 famílias Terena que aceitaram participar do estudo piloto, foram realizadas entrevistas com aplicação de questionário e padronização das técnicas de tomada de medidas antropométricas, possibilitando ajuste do instrumento e preparação para o trabalho de campo com adequação da linguagem e comportamento, considerando as características específicas das famílias indígenas. Os resultados deste estudo foram apresentados no I Congresso Latino Americano de Nutrição (RIBAS et al., 1999b).

\subsection{Processamento e Análise de Dados}

Os dados foram armazenados e analisados em registros no EPI-info versão 6.4 (CDC, WHO 1990). Como método de controle de qualidade da entrada de dados, foi realizada em duplicata por diferentes digitadores, permitindo a confrontação. Ao longo do estudo, realizaram-se análises da consistência dos dados e obtenção de freqüências das variáveis coletadas para identificar e corrigir erros.

Com objetivo de organizar e descrever as informações oriundas da pesquisa, foram elaborados gráficos e tabelas das variáveis envolvidas, nas planilhas do Microsoft Excel 97, sendo calculadas as principais estatísticas de medidas de posição e de dispersão dos dados. Como a amostra estudada foi constituída por $98,9 \%$ das crianças, não foram utilizados procedimentos de inferência estatística, uma vez que as estimativas obtidas são aproximadamente iguais aos parâmetros populacionais. Em duas aldeias foram avaliadas $100 \%$ das crianças. 


\subsection{Aspectos Éticos}

O projeto foi analisado e aprovado pelo Comitê de Ética da Faculdade de Saúde Pública da Universidade de São Paulo e Comissão Nacional de Ética em Pesquisa (Anexos 1 e 2).

Foram realizados contatos prévios com lideranças locais e instituições, com intuito de obter anuência antecipada das comunidades indígenas, onde em linguagem compreensível, foram explicados os objetivos da pesquisa, os métodos e procedimentos da investigação, os benefícios previstos, os possíveis incômodos resultantes da presença física dos pesquisadores na área indígena, a importância da participação no estudo e a garantia de esclarecimentos durante todo o decorrer da pesquisa.

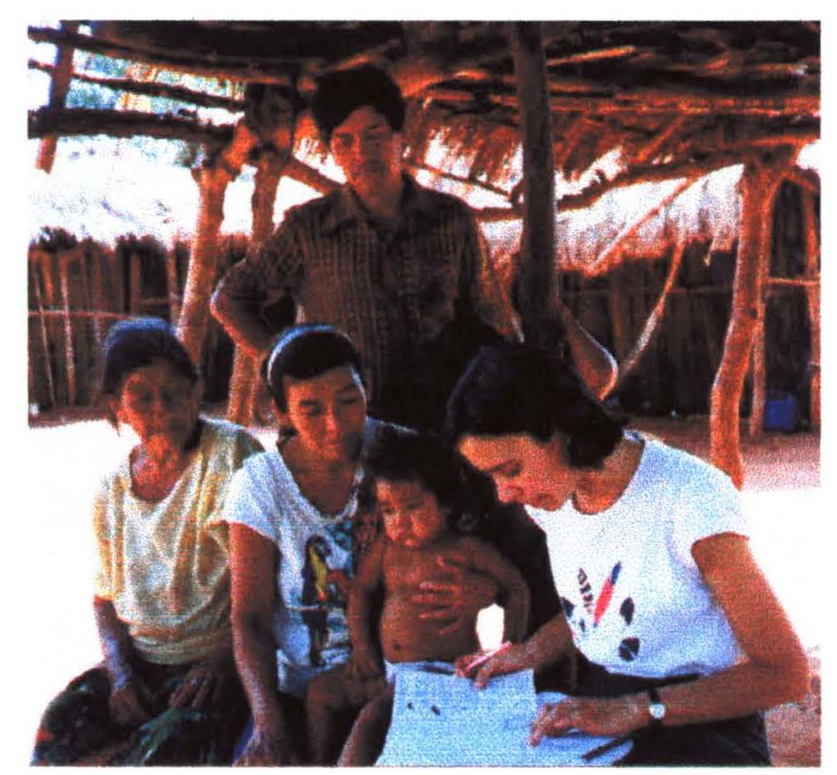

Como benefícios resultantes da pesquisa, destacou-se a relevância social do estudo, informações sobre as condições de saúde e nutrição das crianças, oferecimento de transporte gratuito até um serviço de saúde para as crianças que estavam enfermas por ocasião do estudo e, quando desejado, orientações na área de nutrição.

Figura 12. Apresentação de resultados à família

Somente após obtenção da autorização de ingresso em território indígena (Anexos 3 e 4) e do consentimento livre e esclarecido dos pais das crianças (Anexo 5) os trabalhos tiveram início, informando-se sobre a retirada do consentimento, em qualquer fase da pesquisa. A pesquisa foi desenvolvida com critérios que respeitassem os valores culturais, sociais, morais e éticos, buscando conhecer a 
dinâmica das comunidades para melhor direcionar as ações em campo. Os resultados obtidos tiveram divulgação pública, sendo apresentados inicialmente em linguagem acessível às famílias indígenas (Figuras 12 e 13).

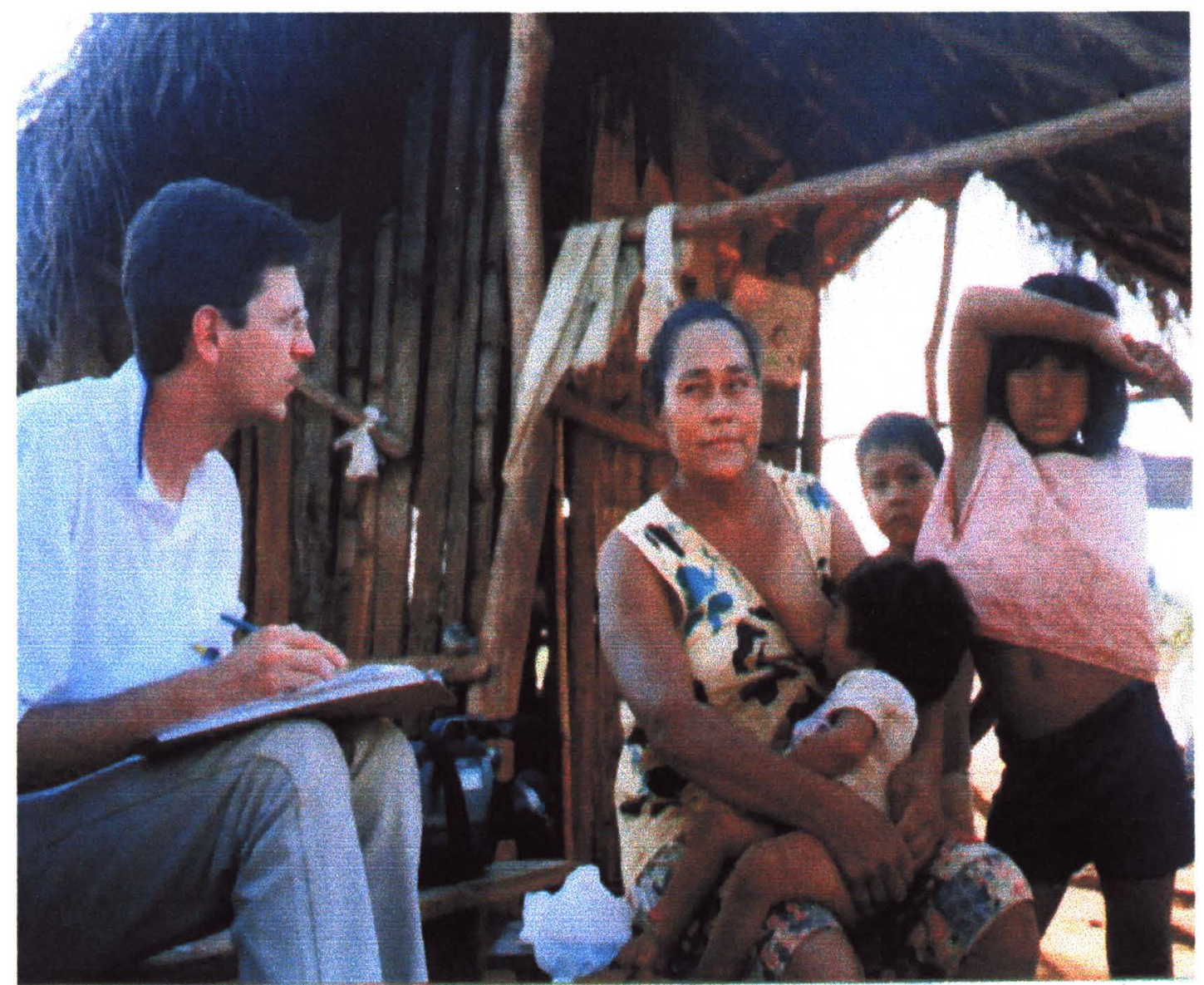

Figura 13. Entrevistador tem o privilégio do encontro e do diálogo. 


\section{RESULTADOS}

Este capítulo encontra-se dividido em duas partes. Na primeira são apresentadas as comunidades Terena com descrição das condições socioeconômicas, demográficas e ambientais das famílias e na segunda os dados referentes às mães e crianças, incluindo determinantes da saúde infantil como, condições de nascimento, disponibilidade da assistência, morbidade e nutrição infantil. Nas tabelas são apresentados os valores referentes a população e nas figuras os valores com distribuição comparativa e identificação das diferentes comunidades estudadas.

\subsection{Comunidades Terena}

\subsubsection{Características Socioeconômicas}

A Tabela 1 descreve a renda familiar per capita de 212 famílias indígenas residentes nas Aldeias Tereré, Buriti, Córrego do Meio e Água Azul onde, 87,7\% encontravam-se na faixa de $0 \vdash 0,5$ salário mínimo (s.m.), $10,9 \%$ na faixa de $0,5 \vdash 1,0$ s.m. e $1,4 \%$ com renda $\geq 1$ s.m..

Tabela 1. Distribuição das famílias indígenas segundo a localização dos domicílios e renda familiar per capita. Comunidades Terena, MS, Brasil, 1999.

\begin{tabular}{lcc}
\hline VARIÁVEIS & TOTAL & $\%$ \\
\hline Aldeias & & \\
Tereré & 35 & 16,6 \\
Buriti & 77 & 36,3 \\
Córrego do Meio & 59 & 27,8 \\
Água Azul & 41 & 19,3 \\
Renda familiar per capita (salário mínimo de dez/1999) & & \\
$0 \vdash 0,5$ & 186 & 87,7 \\
$0,5 \vdash 1,0$ & 23 & 10,9 \\
$\geq 1,0$ & 3 & 1,4 \\
\hline
\end{tabular}


Neste estudo foi considerado o valor de R\$136,00 (cento e trinta e seis reais), para o salário mínimo em vigor (dezembro de 1999), que representava a remuneração mínima do trabalhador fixada por lei.

A Figura 14 apresenta a distribuição percentual da renda familiar per capita, segundo as diferentes aldeias onde, observa-se baixa renda em todas as comunidades, podendo levar ao comprometimento da garantia de bens materiais e de consumo entre eles, a segurança alimentar do domicílio .

A Aldeia Tereré apresenta $17,1 \%$ das famílias com renda per capita superior a 0,5 s.m. provavelmente, explicada pelos chefes de família empregados no município de Sidrolândia, por tratar-se de uma comunidade indígena localizada no perímetro urbano.

Figura 14. Distribuição percentual da renda familiar per capita. Comunidades Terena, MS, Brasil, 1999.

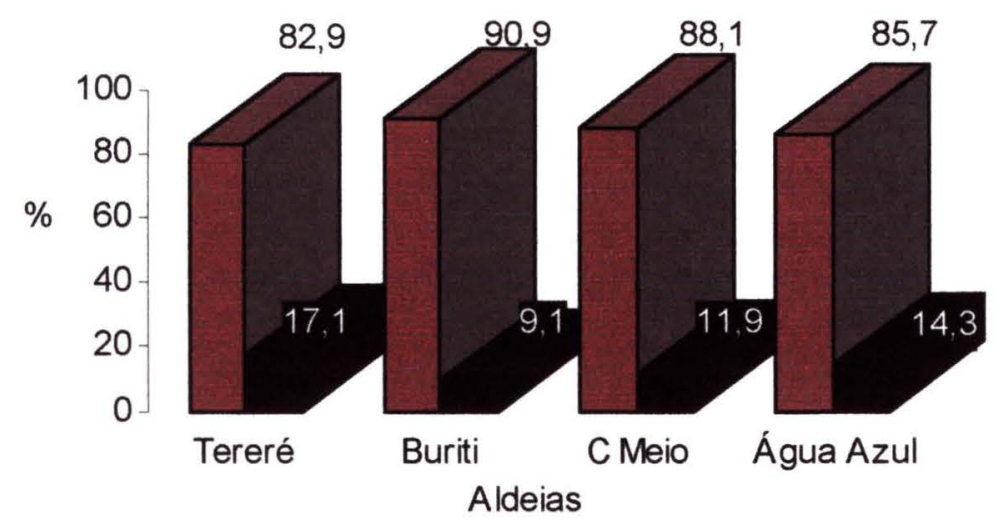

@ $<$ 0,5 salário mínimo $\mathbf{\square}>0,5$ salário mínimo 
De acordo com a Tabela 2 a escolaridade foi classificada em anos de estudo de 212 mães e 201 pais sendo que, $12,3 \%$ das mães não haviam recebido nenhuma instrução escolar, $66,0 \%$ possuíam de 1 a 4 anos de estudo, $19,8 \%$ de 5 a 8 anos e $1,9 \%$ acima de 8 anos. Entre os pais $4,3 \%$ sem escolaridade, $62,7 \%$ possuíam de 1 a 4 anos, $25,0 \%$ de 5 a 8 anos, $2,8 \%$ acima de 8 anos de escolaridade e 5,2\% sem informações. Cada Aldeia possui uma escola administrada pela rede municipal de ensino com oferecimento do ensino fundamental.

Tabela 2. Distribuição das famílias indígenas segundo escolaridade dos pais e ocupações do chefe de família. Comunidades Terena, MS, Brasil, 1999.

\begin{tabular}{lcc}
\hline VARIÁVEIS & TOTAL & $\%$ \\
\hline Escolaridade materna (anos de estudo) & & \\
Sem escolaridade & 26 & 12,3 \\
$1-4$ & 140 & 66,0 \\
$5-8$ & 42 & 19,8 \\
$>8$ & 4 & 1,9 \\
Escolaridade paterna (anos de estudo) & & \\
Sem escolaridade & 9 & 4,3 \\
$1-4$ & 133 & 62,7 \\
$5-8$ & 53 & 25,0 \\
$>8$ & 6 & 2,8 \\
Sem informações & 11 & 5,2 \\
& & \\
Ocupações do chefe de família & 160 & 75,5 \\
Agropecuárias & 15 & 7,1 \\
Técnicos e profissionais liberais & 8 & 3,8 \\
Serviços domésticos & 7 & 3,3 \\
Construção civil & 5 & 2,3 \\
Comércio (vendedores) & 4 & 1,9 \\
Produção (indústria de alimentos) & 3 & 1,4 \\
Autônomos (proprietários) & 10 & 4,7 \\
Outras atividades & & \\
\hline
\end{tabular}

As Figuras 15 e 16 apresentam a distribuição percentual da escolaridade dos pais nas quatro aldeias onde, observa-se baixos níveis de escolaridade em todas as comunidades, especialmente entre as mulheres, com predomínio de 1 a 4 anos de estudo, constituindo um fator de risco para a saúde infantil, já comprovado em inúmeros estudos (MONTEIRO 1979; COCHRANE et al., 1980; VALLIN 1985; CLELAND e GINNEKEN 1988; FIBGE 1989). 
Figura 15. Distribuição percentual da escolaridade materna. Comunidades Terena, MS, Brasil, 1999.

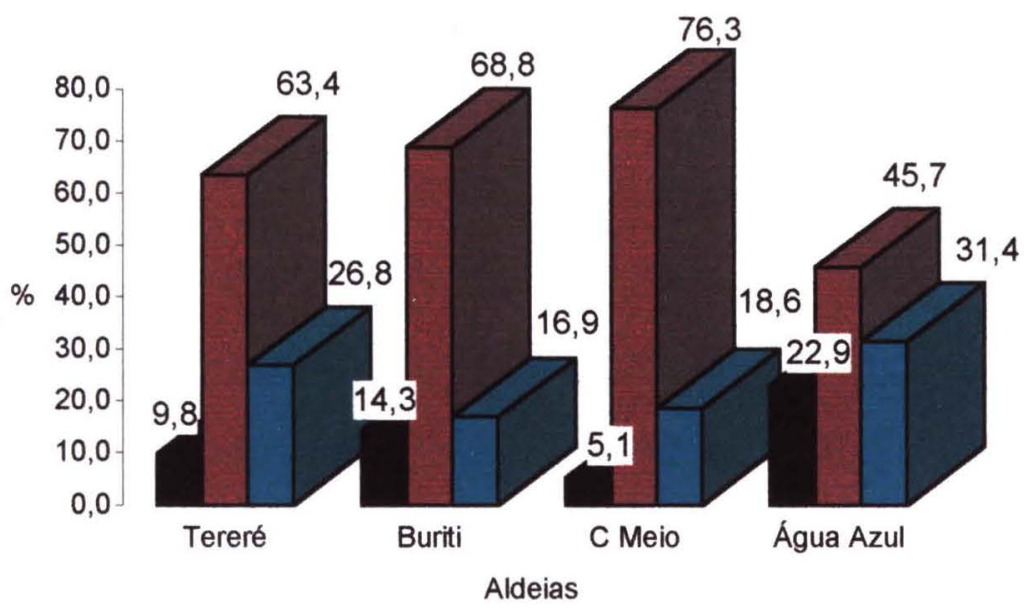

asem escolaridade $\square 1$ a 4 anos $\square>4$ anos

Figura 16. Distribuição percentual da escolaridade paterna. Comunidades Terena, MS, Brasil, 1999.

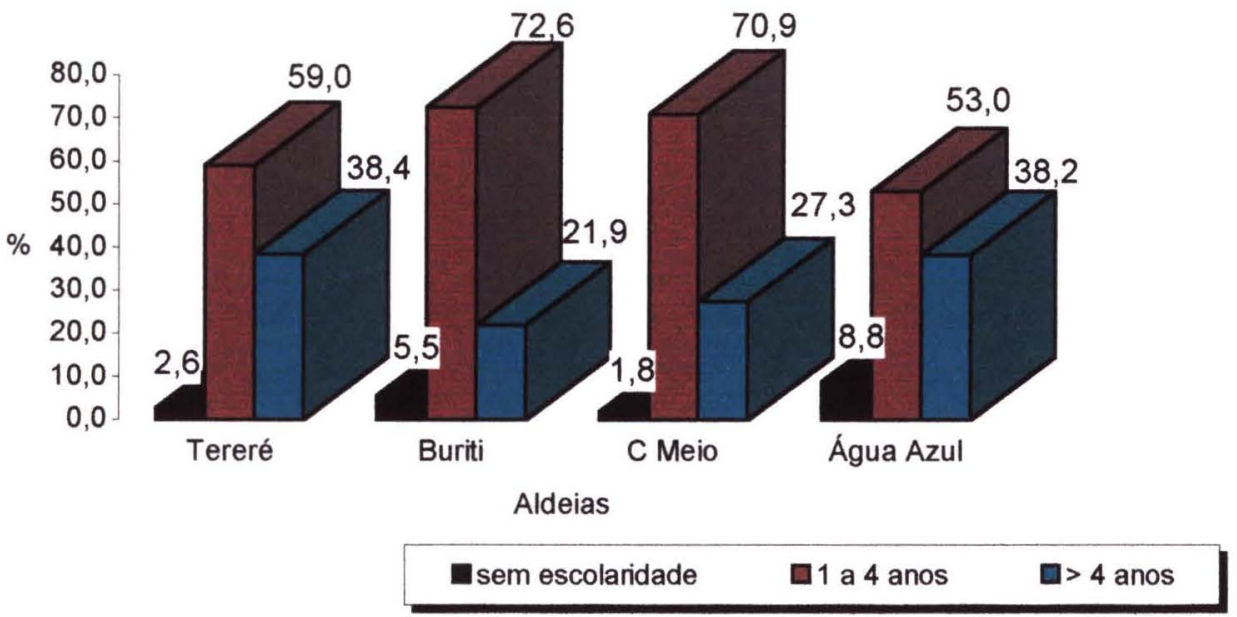

No estudo da ocupação principal do chefe da família (Tabela 2) observou-se que $75,5 \%$ desenvolviam atividades agropecuárias, incluindo plantio e colheita de 
roças na própria comunidade indígena $(54,3 \%)$, corte de cana em usinas $(14,6 \%)$ e atividades pecuárias em fazendas da região $(6,6 \%)$. As demais ocupações observadas foram: técnicos e profissionais liberais $(7,1 \%)$, empregados domésticos $(3,8 \%)$, empregados da construção civil $(3,3 \%)$, vendedores $(2,3 \%)$, trabalhadores da indústria de alimentos $(1,9 \%)$, autônomos $(1,4 \%)$ e outras atividades $(4,7 \%)$.

Os Terena autodenominam-se como poké'e que significa terra, são essencialmente agricultores. Relato de lideranças referem que no passado a agricultura, a caça, pesca e a coleta de frutos e raízes eram as atividades de subsistência mas no presente há necessidade da busca do trabalho, principalmente devido à redução territorial, degradação dos recursos naturais e crescimento populacional o que, por si só, justifica a importância de garantir o direito às áreas com extensão adequada.

Quanto à utilização da terra disponível foi identificada a existência de 79,5\% de domicílios com roças, $54,8 \%$ com pomar e $8,6 \%$ com hortas. Nas roças foi observado basicamente o cultivo de mandioca, arroz, feijão, milho, abóbora e batata doce e, em algumas delas, abacaxi, banana, melancia, cana de açúcar, amendoim e algodão, variando de acordo com a área pertencente à família e a época do ano. A base da produção agrícola é familiar.

$\mathrm{Na}$ última safra $66,3 \%$ destinaram a produção exclusivamente para o consumo da própria família, 4,2\% distribuíram entre outras famílias da comunidade e $29,5 \%$ comercializaram os produtos. A distribuição da produção de alimentos entre as famílias era baseada nas regras de parentesco e de reciprocidade, onde são constantes as doações recíprocas de alimentos e de prestação de serviços.

Cada família possuía uma área disponível para plantar variando de 1 à 10 hectares, com predomínio de áreas menores. Não existe delimitação das áreas com cercas mas todos têm claro os limites e o respeito para com a terra alheia e os produtos do trabalho. Foram observadas áreas comuns como o espaço para construção das casas e pomares, o espaço para a circulação e o espaço familiar que circunda as casas destinado às roças e pequenas capoeiras de mata, onde retiram madeira, taquaras, sementes, corantes, palha e frutos. Além das roças e capoeiras não há um território de mata densa com caça. As quatro aldeias estudadas dispõem de campo de futebol. 
É importante lembrar que para que um povo indigena possa sobreviver e se reproduzir necessita mais terra do que as que utiliza simplesmente para plantar. Os Terena utilizam critérios particulares para classificar o espaço destinado às plantações. As roças circundam a aldeia e são anuais, com exceção do milho que o plantio é bianual. Em áreas próximas dos domicílios são plantadas em pequena escala, cana-de-açúcar, banana e abacaxi As capoeiras são destinadas para 0 descanso da terra, à reprodução de pequenos animais e de materiais simbólicos utilizados nos rituais e tratamentos de saúde. Todos têm acesso à terra e esse acesso é efetivado através do trabalho que cada família desenvolve numa determinada porção do território.

$\mathrm{Na}$ Área Buritizinho onde se localiza a Aldeia Tereré, não existe a disponibilidade territorial necessária para implementação de roças uma vez que, a área total da aldeia corresponde a 10 hectares distribuídos com 62 domicílios, casa de reza, escola, centro de reuniões, campo de futebol e horta comunitária.

\subsubsection{Características Demográficas}

Tabela 3. Distribuição das características demográficas de famílias Terena, MS, Brasil, 1999.

\begin{tabular}{|c|c|}
\hline VARIÁVEIS & \\
\hline \multicolumn{2}{|l|}{ Idade das mães } \\
\hline Média & 26,1 \\
\hline Desvio padrão & 7,3 \\
\hline Mínima & 15 \\
\hline Máxima & 53 \\
\hline \multicolumn{2}{|l|}{ Idade dos pais } \\
\hline Média & 31,0 \\
\hline Desvio padrão & 10,0 \\
\hline Mínima & 16 \\
\hline Máxima & 69 \\
\hline \multicolumn{2}{|l|}{ História reprodutiva } \\
\hline Abortos & $13,7 \%$ \\
\hline Natimortos & $1,4 \%$ \\
\hline Número de filhos nascidos vivos - Média & 3,8 \\
\hline $\begin{array}{ll}\text { Desvio padrão } \\
\end{array}$ & 2,7 \\
\hline Número de filhos vivos no periodo estudado - Média & 3,5 \\
\hline Desvio padrão & 2,4 \\
\hline \multicolumn{2}{|l|}{ Densidade familiar } \\
\hline Pessoas residentes por domicílio - Média & 6,8 \\
\hline Desvio padrão & 2,9 \\
\hline
\end{tabular}


A Tabela 3 apresenta as características demográficas das famílias estudadas, onde a idade média das mães era de 26,1 anos, desvio padrão de 7,3 anos, sendo $15,2 \%$ menores de 20 anos e $0,5 \%$ acima de 50 anos. Para os pais a idade média era de 31,0 anos, desvio padrão de 10,0 anos, sendo 6,5\% menores de 20 anos e 5,9\% acima de 50 anos.

Quanto ao número de filhos nascidos vivos observou-se a média de 3,8 filhos com desvio padrão de 2,7 filhos. O número de filhos vivos no período estudado apresentou a média de 3,5 filhos, com desvio padrão de 2,4. Na história reprodutiva $13,7 \%$ das mães relataram a ocorrência de abortos, com a média de 1,7 abortos e desvio padrão de 0,97 . Na avaliação da densidade familiar a média de pessoas residentes por domicílio foi de 6,8 moradores, com desvio padrão de 2,9 .

\subsubsection{Características Ambientais}

As Tabelas 4 e 5 apresentam as características ambientais dos domicílios onde observa-se condições potencialmente insalubres, especialmente com relação ao escoadouro de dejetos e destino de resíduos.

Tabela 4. Distribuição das características ambientais dos domicílios. Comunidades Terena, MS, Brasil, 1999.

\begin{tabular}{lrr}
\hline VARIÁVEIS & TOTAL & $\%$ \\
\hline Abastecimento de água & & \\
Rede geral de distribuição & 30 & 14,1 \\
Coleta em rios e poços rasos & 12 & 5,7 \\
Poço artesiano & 170 & 80,2 \\
Escoadouro dos dejetos & & \\
Fossa séptica & 39 & 18,4 \\
Vala negra & 151 & 71,2 \\
Céu aberto & 22 & 10,4 \\
Destino do lixo & & \\
Coletado diretamente & 39 & 18,4 \\
Queimado/Enterrado & 142 & 67,0 \\
Lançado ao redor do domicílio & 31 & 14,6 \\
Sistema de iluminação & & \\
Luz elétrica & 139 & 65,6 \\
Lamparina ou similar & 73 & 34,4 \\
\hline
\end{tabular}


O abastecimento de água era realizado através de poços artesianos $(80,2 \%)$, rede geral de distribuição $(14,1 \%)$ e coleta manual em rios e poços rasos $(5,7 \%)$.

A Figura 17 apresenta a sistema de abastecimento de água por aldeias onde, observa-se melhores condições na Aldeia Tereré, por contar com sistema público de abastecimento de água do município de Sidrolândia.

Figura 17. Distribuição percentual do abastecimento de água. Comunidades Terena, MS, Brasil, 1999.

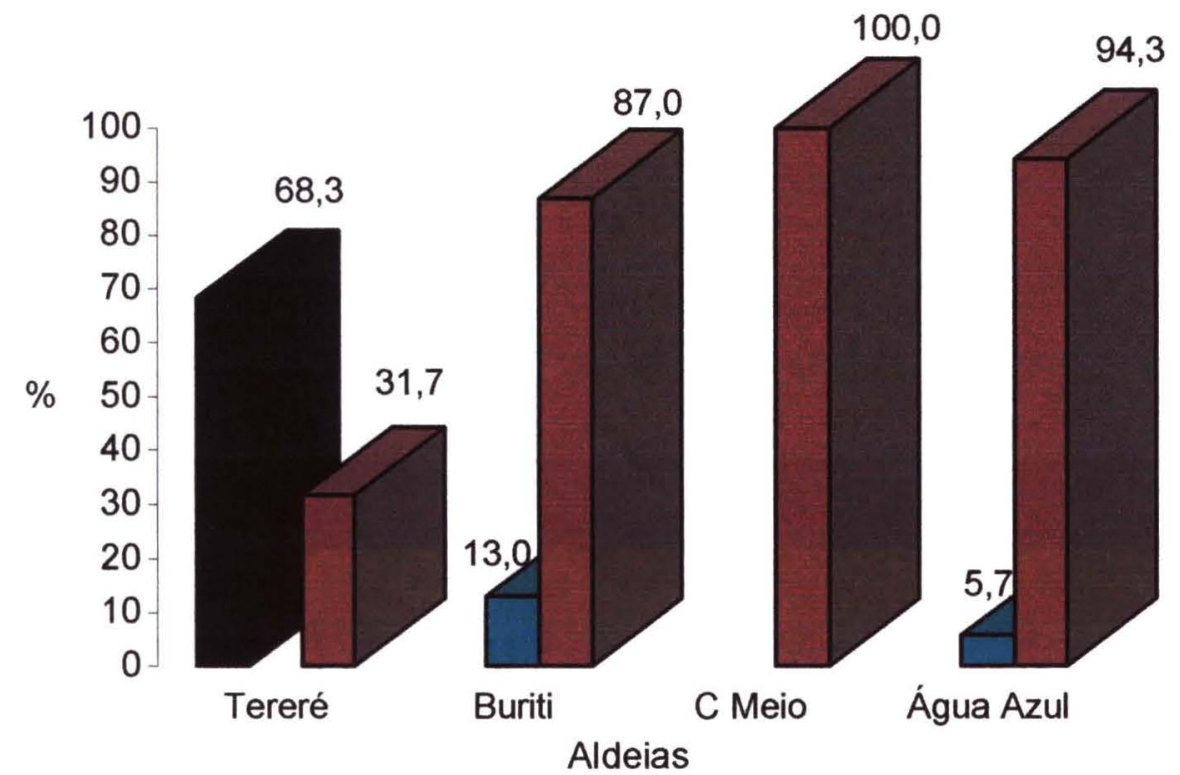

urede geral $\square$ rios/poços rasos $\square$ poço artesiano

A implantação do sistema de abastecimento de água através de poços artesianos só ocorreu no ano de 1995 nas Aldeias Buriti, Córrego do Meio e Água Azul. Nas Aldeias Buriti e Água Azul, onde respectivamente 13,0\% e 5,7\% das famílias obtém água em rios e poços rasos escavados, a coleta é realizada em vasilhames e transportados manualmente para os domicílios. Os rios são também utilizados para banhos, lavagem de roupas e por animais (Figura 18). 


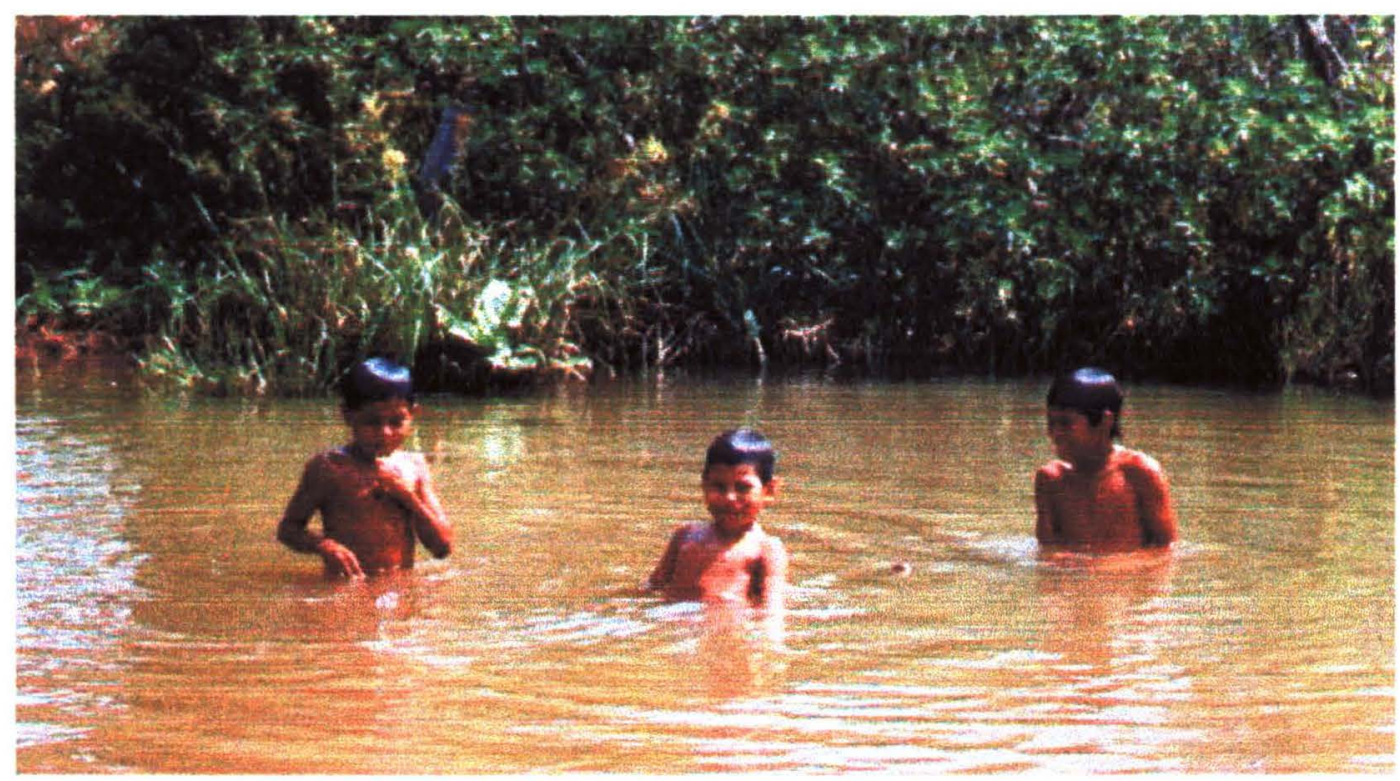

Figura 18. Meninos brincam no rio

Com relação ao escoamento dos dejetos $71,2 \%$ eram retidos em fossas negras, $18,4 \%$ em fossa séptica e 10,4\% lançados pelo solo da mata circunvizinha (Figura 19).

Quanto ao destino do lixo 67,0\% queimavam ou enterravam, 14,6\% lançavam no solo ao redor do domicílio e $18,4 \%$ contavam com coleta pública regular, representado exclusivamente pelos moradores da Aldeia Tereré. 


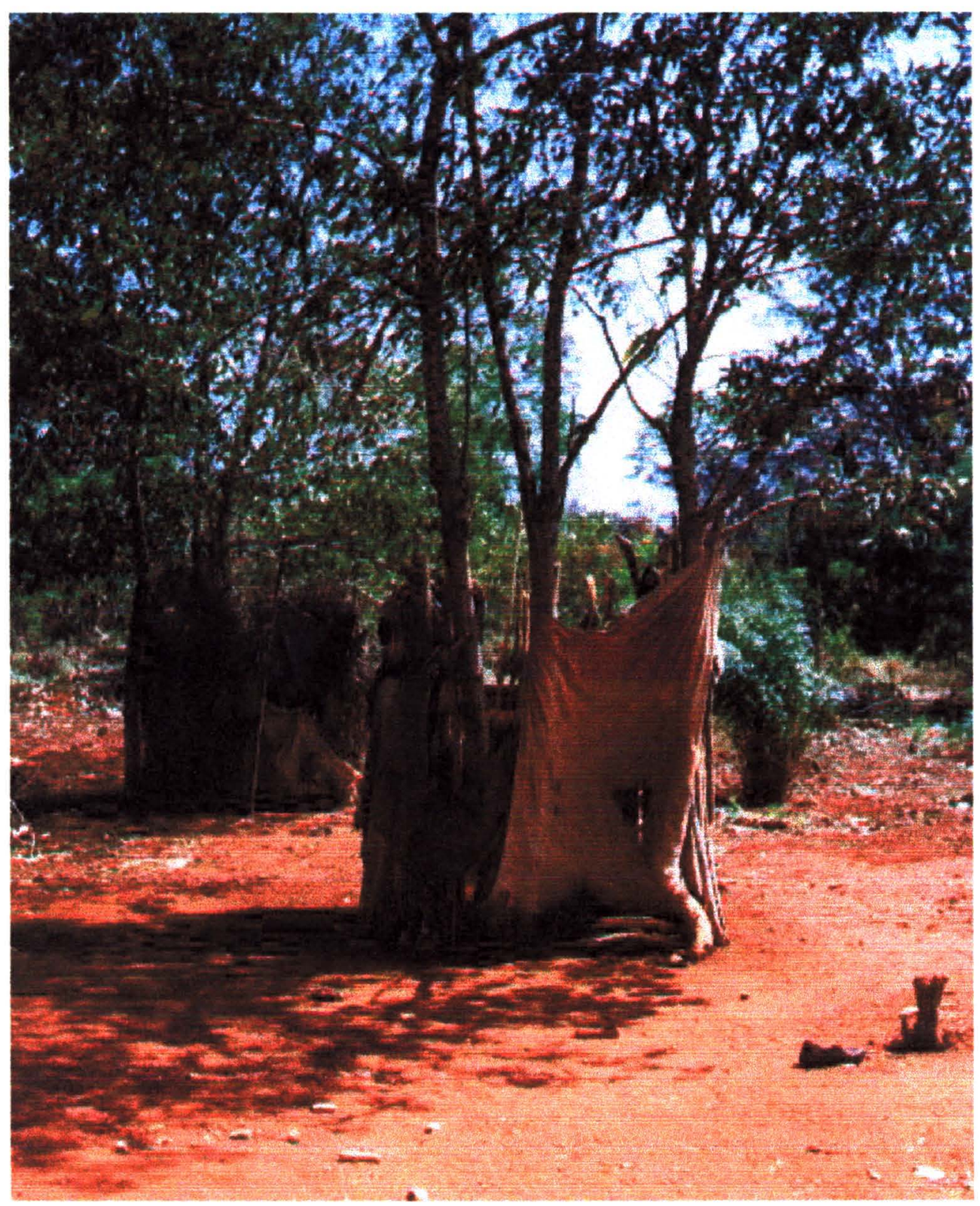

Figura 19. Instalações sanitárias

As Figuras 20 e 21 apresentam o sistema de esgoto e tratamento do lixo nas comunidades estudadas onde, as condições inadequadas de escoamento de dejetos, com provável contaminação do solo, caracteriza as dificuldades encontradas na obtenção de instalações sanitárias adequadas assim como, a carência de informações sobre os efeitos nocivos das condições insalubres. 
Figura 20. Distribuição percentual do escoamento de dejetos. Comunidades Terena, MS, Brasil, 1999.

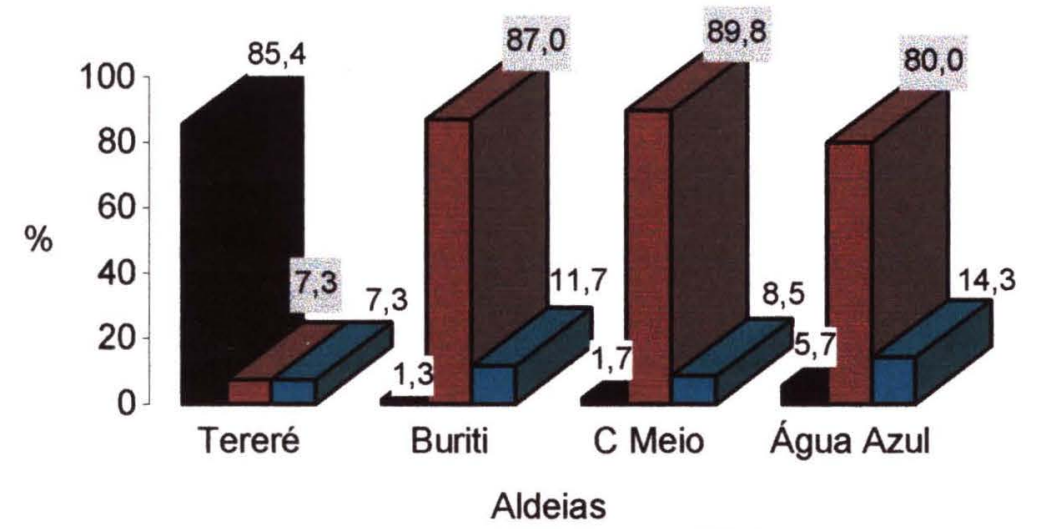

$\square$ fossa séptica $\square$ vala negra $\square$ céu aberto

Figura 21. Distribuição percentual do destino do lixo. Comunidades Terena, MS, Brasil, 1999.
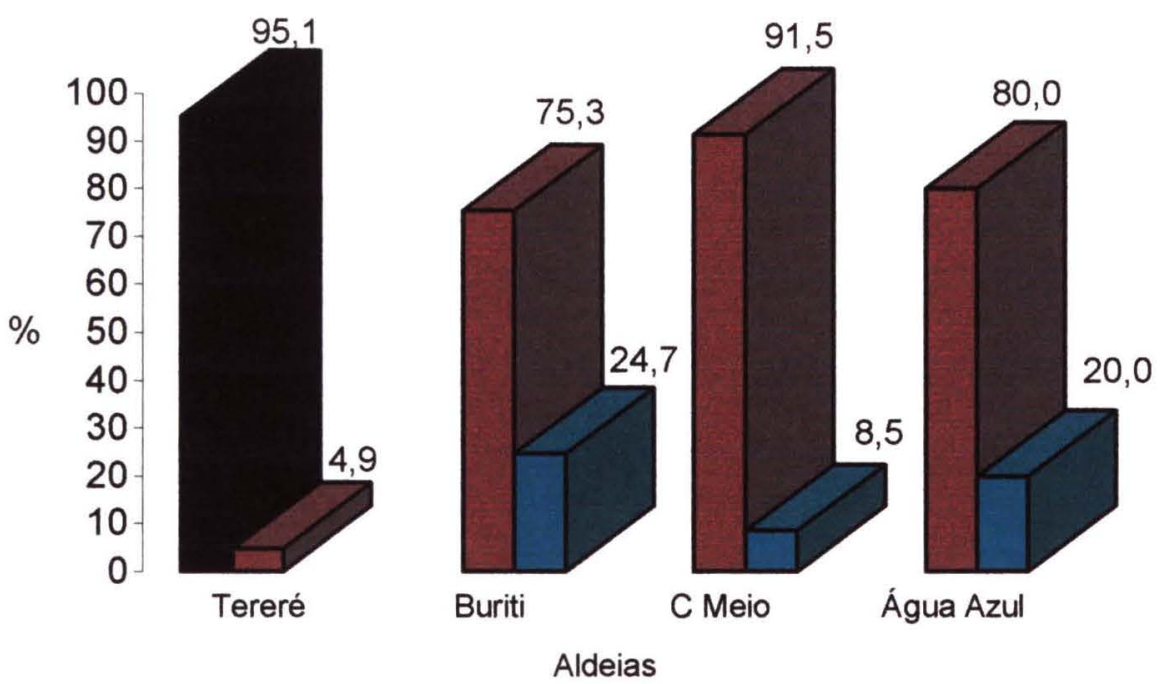

coletado $\square$ queimado/enterrado $\square$ espalhado pelo solo

Com relação à fonte de iluminação $65,6 \%$ possuíam luz elétrica. Embora exista rede de energia elétrica em todas as aldeias, muitas famílias não tinham acesso a esse 
benefício em função da localização da moradia pois, a rede de transmissão está distribuída na região central das comunidades, não interligando os domicílios mais afastados conforme ilustra a Figura 22.

Figura 22. Distribuição percentual de energia elétrica dos domicílios. Comunidades Terena, MS, Brasil, 1999.

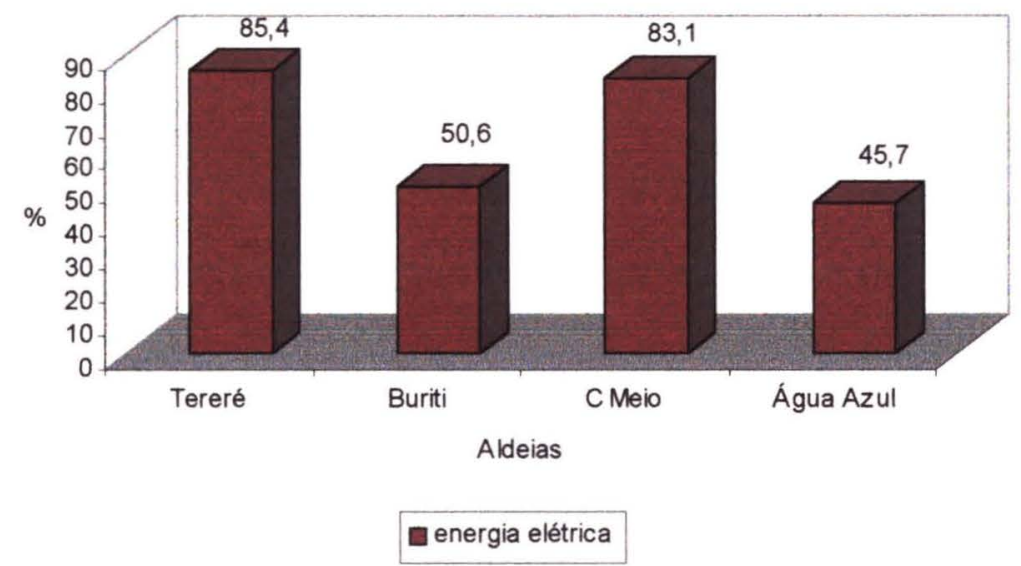

A Tabela 5 apresenta a caracterização dos domicílios onde, $71,2 \%$ não possuíam revestimento no piso (chão batido), 25,5\% cimentado e 3,3\% com revestimento cerâmico. Quanto à cobertura $64,2 \%$ dos domićlios eram de sapé ou folhas de buriti. Esta cobertura dura em média dez anos, mantendo temperatura amena no interior do domicílio. A extração do sapé, taquarussu e troncos do bacuri utilizados nas construções é efetuada na mata de forma escalonada, variando de acordo com as fases da lua, com a finalidade de evitar a proliferação de insetos. A constituição das paredes eram 70,3\% de taquarussu e bacuri, partidos ao meio. 
Tabela 5. Distribuição das características de construção e disponibilidade de equipamentos nos domicílios. Comunidades Terena, MS, Brasil, 1999.

\begin{tabular}{lrr}
\hline VARIÁVEIS & TOTAL & $\%$ \\
\hline Revestimento do piso & & \\
Sem revestimento (chão batido) & 151 & 71,2 \\
Cimentado & 54 & 25,5 \\
Cerâmico & 7 & 3,3 \\
Material de cobertura & & \\
Telha & 76 & 35,8 \\
Sapé/Palha de buriti & 136 & 64,2 \\
Material da parede & & \\
Alvenaria & 63 & 29,7 \\
Taquarussu/Tronco de bacuri & 149 & 70,3 \\
& & \\
Número de cômodos utilizados para dormir & & \\
1 a 2 & 186 & 87,7 \\
+ 2 & 26 & 12,3 \\
Presença de equipamentos domésticos & & \\
Fogão à gás & 133 & 62,7 \\
Rádio & 106 & 50,0 \\
Televisão & 85 & 40,1 \\
Geladeira & 56 & 26,4 \\
Aparelho de som & 41 & 19,3 \\
Freezer & 7 & 3,3 \\
\hline
\end{tabular}

As Figuras 23, 24 e 25 apresentam as características dos domicílios onde, as construções rústicas, com maior utilização de materiais disponíveis na natureza são utilizados pelas aldeias mais distantes como, Buriti, Córrego do Meio e Água Azul.

Figura 23. Distribuição percentual do material de construção das paredes dos domicílios. Comunidades Terena, MS, Brasil, 1999.

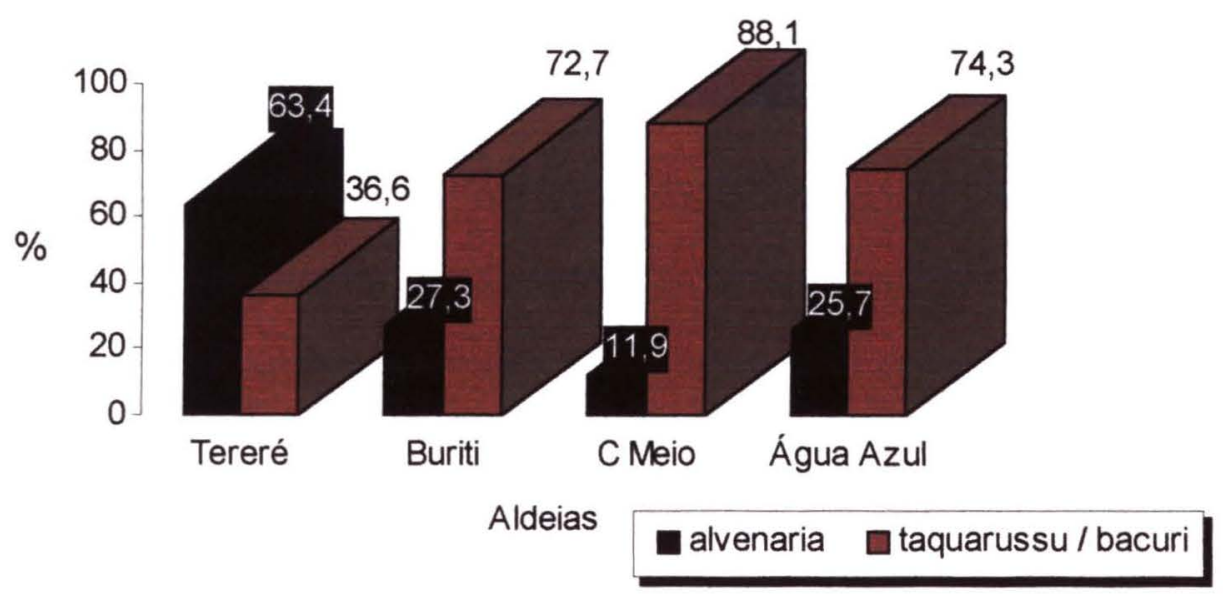


Figura 24. Distribuição percentual do material de cobertura dos domicílios. Comunidades indígenas Terena, MS, Brasil, 1999.

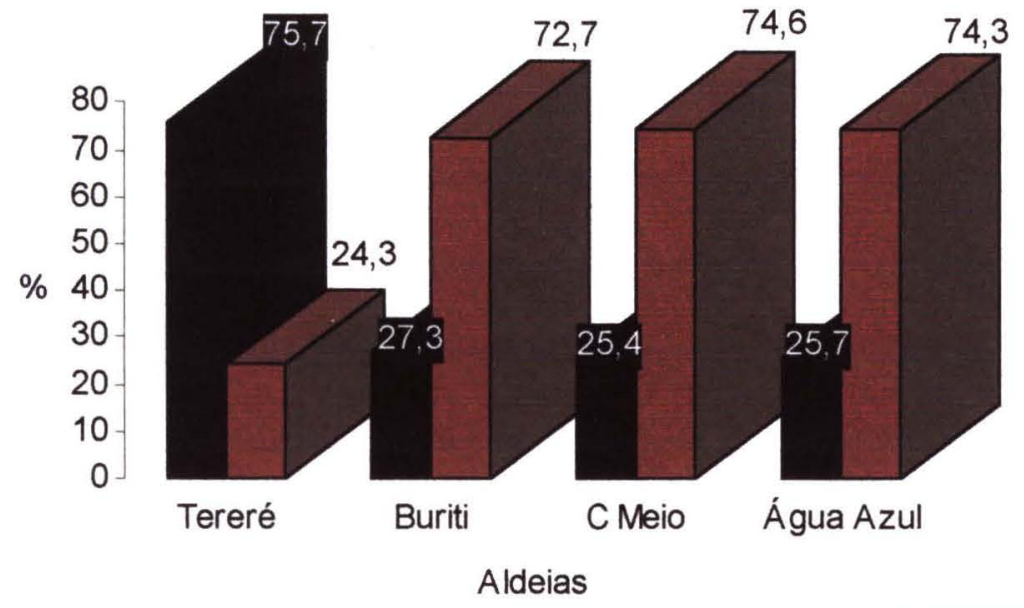

telha $\square$ sapé / palha

Figura 25. Distribuição percentual das características do piso dos domicílios. Comunidades indígenas Terena, MS, Brasil, 1999.

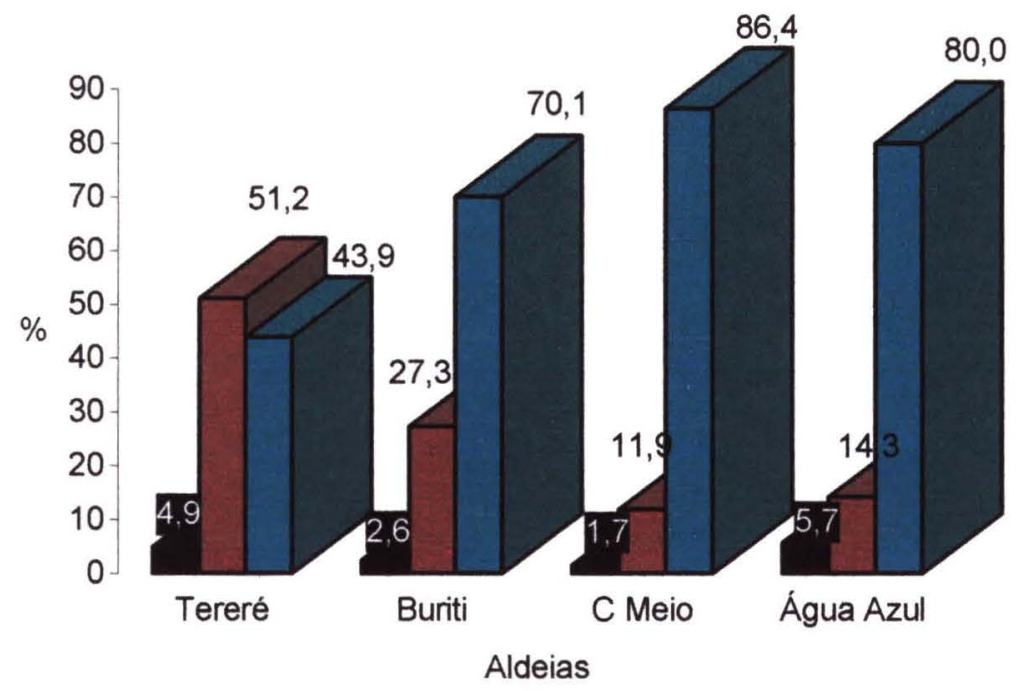


Quanto ao número de cômodos utilizados para dormir na moradia $87,7 \%$ possuíam 1 a 2 cômodos, o que representa a precária disponibilidade de espaço, considerando o número de moradores por domicílio.

A Tabela 5 registra ainda a presença de equipamentos domésticos onde, 62,7\% domicílios possuíam fogão à gás, 50,0\% com rádio, 40,1\% com televisão, 26,4\% com geladeira, $19,3 \%$ com aparelho de som e 3,3\% com freezer.

\subsection{Mães e Crianças}

As crianças crescem livres, acompanhando a mãe e a avó em todos os lugares. Quando pequena dorme durante o dia em rede amarada na árvore mais próxima, permitindo que a mãe desenvolva seus trabalhos ao redor da casa ou acompanha irmãos mais velhos (Anexo 8 ).

Por volta dos dez meses engatinha pelo terreno coberto de pó, cinzas e folhas, levando à boca tudo o que encontra no caminho. Os pais acompanham a exploração do ambiente com olhar amoroso, sem interromper os movimentos da criança. Quando aprende a andar, brinca com irmãos e vizinhos, explorando lugares mais afastados (Figura 26). Os pais e avós passam muitas horas junto delas e não as repreendem.

Ao redor dos sete anos vão à escola da aldeia em um período e no outro participam ativamente da vida comunitária. Para as meninas inicia-se o processo de aprendizagem das atividades do domicílio, acompanhando a mãe e a avó no afazeres diários. Os meninos acompanham o pai, avô e tios desenvolvendo atividades na roça, aprendendo a plantar e reconhecer árvores pelas folhas, troncos e sementes. Dos animais aprendem as características corporais e comportamentais, sabendo identificálos pelas pegadas ou ruídos emitidos. As crianças da Aldeia Tereré não participam destas atividades considerando as restrições ambientais da área urbana. Nesta idade as crianças são receptivas aos ensinamentos dos adultos e nutrem grande afeição aos avós. O processo de aprendizagem é através da transmissão oral, sendo a convivência diária e prolongada com os avós, insubstituíveis. Não é claro a idade em que deixam de ser consideradas crianças, mas iniciam no mundo dos adultos quando casam. 
A Tabela 6 descreve as características das 354 crianças estudadas (98,9\%) sendo, 172 do sexo masculino e 182 do feminino, estando distribuídas por local de moradia e grupo etário.

Tabela 6. Distribuição das crianças segundo local de moradia, sexo e idade. Comunidades Terena, MS, Brasil, 1999.

\begin{tabular}{|c|c|c|}
\hline VARIÁVEIS & TOTAL & $\%$ \\
\hline \multicolumn{3}{|c|}{ Local de moradia (Aldeia) } \\
\hline Tereré & 61 & 17,2 \\
\hline Buriti & 129 & 36,4 \\
\hline Córrego do Meio & 100 & 28,3 \\
\hline Água Azul & 64 & 18,1 \\
\hline \multicolumn{3}{|l|}{ Sexo } \\
\hline Masculino & 172 & 48,6 \\
\hline Feminino & 182 & 51,4 \\
\hline \multicolumn{3}{|l|}{ Idade (meses) } \\
\hline $0 \vdash 6$ & 44 & 12,4 \\
\hline $6 \vdash-12$ & 42 & 11,9 \\
\hline $12 \vdash-18$ & 36 & 10,2 \\
\hline $18 \vdash 24$ & 44 & 12,4 \\
\hline $24 \vdash-36$ & 66 & 18,6 \\
\hline $36 \vdash-48$ & 71 & 20,1 \\
\hline $48-60$ & 51 & 14,4 \\
\hline
\end{tabular}

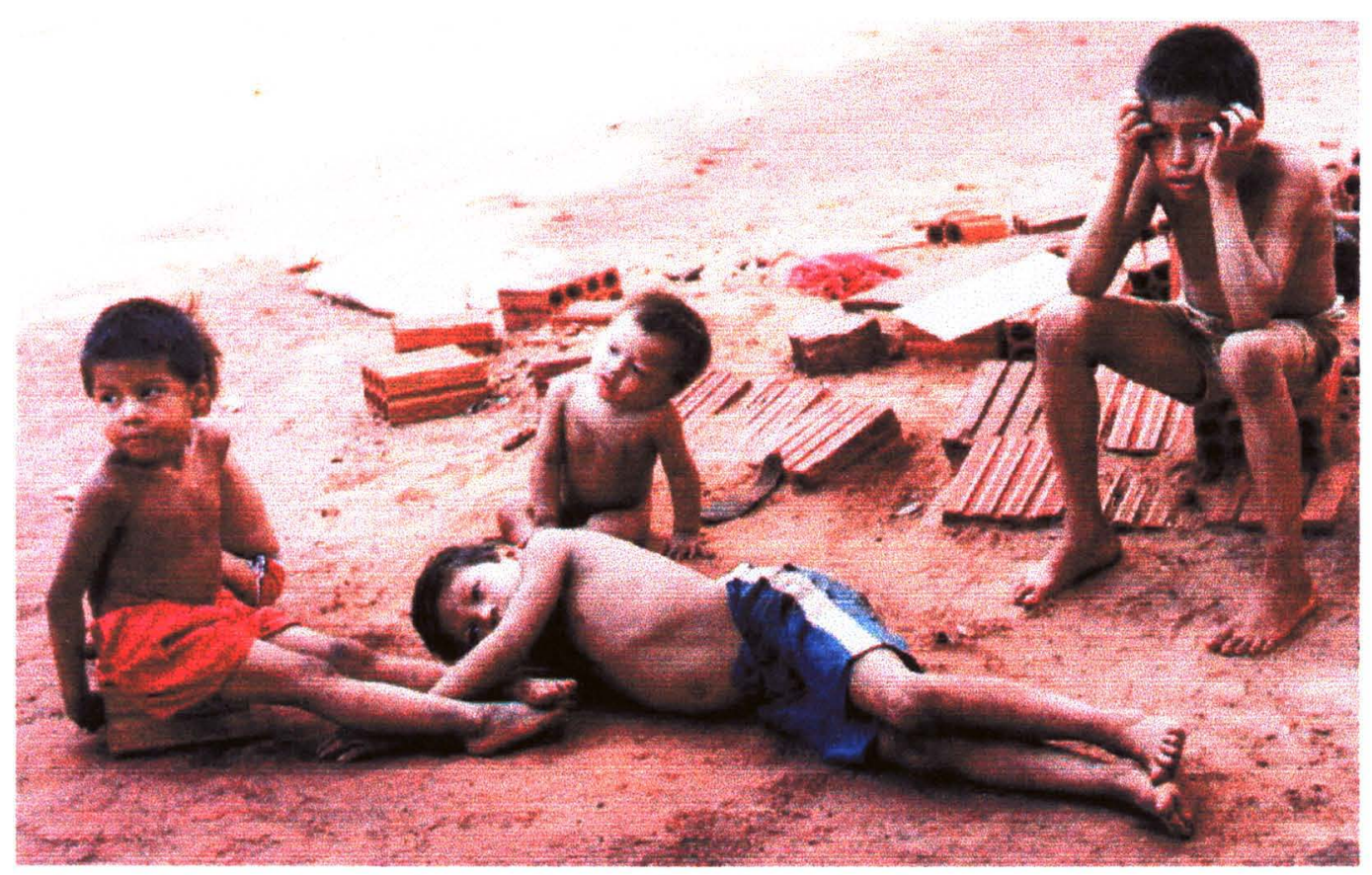

Figura 26. Brincadeiras infantis revelam as dificuldades da vida Terena. 


\subsubsection{Assistência à Saúde}

O sistema de atenção à saúde indígena no período de análise corresponde ao início das atividades coordenadas diretamente pela FUNASA. Período caracterizado pela definição de aspectos técnicos para a implantação do novo modelo assistencial e também de descontinuidade de ações de promoção e assistência à saúde em nível local.

O atendimento da população ocorria em dois postos de saúde localizados na Aldeia Buriti e Água Azul, com serviços de atenção primária desenvolvidos por profissionais indígenas sendo, três agentes de saúde, dois auxiliares de enfermagem e dois atendentes de enfermagem. A Aldeia Córrego do Meio não dispunha de unidade de saúde, apesar de ser uma antiga e constante reivindicação dos moradores.

As unidades de atendimento encontravam-se em condições precárias, com sinais aparentes de abandono e desgaste da estrutura física, insuficiência de equipamentos e medicamentos, longos períodos sem visitas de profissionais médicos e dificuldades para remoção dos pacientes em casos de emergência.

As Aldeias Buriti e Água Azul recebiam apoio da prefeitura de Dois Irmãos do Buriti que quando notificadas, enviavam ambulância até a aldeia. Os casos graves eram encaminhados às unidades de saúde do município mais próximo, localizado aproximadamente a $35 \mathrm{Km}$.

A repressão da demanda não ocorria somente pela escassez da oferta de serviços em nível local, mas também por barreiras físicas, econômicas e culturais, representadas pela descontinuidade de visitas de profissionais de saúde na área indigena, carência de recursos financeiros para o pagamento de condução, taxa cobrada no hospital público, enfrentamento de ações discriminatórias no atendimento, dificuldades de comunicação com os profissionais de saúde e medo da possibilidade de internação que provocaria o distanciamento do núcleo familiar.

Os residentes na Aldeia Tereré localizada no perímetro urbano de Sidrolândia, contavam com o atendimento oferecido pela unidade básica de saúde e hospital de pequeno porte. Neste hospital era cobrado uma taxa como pagamento da consulta médica, apesar do convênio com o Sistema Único de Saúde. 
Com relação ao sistema tradicional de cura de enfermidades o xamã (Koixomuneti), era consultado ao mesmo tempo que recorriam aos cuidados médicos da unidade de saúde. Como em outros grupos indígenas "a busca pela medicina ocidental é vista como uma alternativa adicional, complementar aos recursos existentes na comunidade indigena" (BUCHILLET 1991 p. ).

Os partos domiciliares eram auxiliados por parteiras tradicionais, representando recursos humanos de grande valor e credibilidade na comunidade indigena. Essas parteiras não recebiam treinamento, remuneração, exerciam as atividades sem materiais que garantissem condições higiênicas no parto e não existia vínculo entre os atendimentos realizados e os serviços de saúde. Em relatos de idosos, no passado as avós eram as responsáveis por todos os partos da comunidade, além dos cuidados com a mãe e criança nos primeiros sete dias. Nesses dias a alimentação oferecida às mães era composta basicamente de caldos de mandioca, arroz e galinha, além de chás com objetivos de restabelecer as forças e proporcionar aumento na produção de leite materno. Infusões de ervas eram preparadas para banhos terapêuticos. Atualmente a restrição alimentar observada entre as parturientes se restringe ao consumo de carne de porco.

A Tabela 7 apresenta as características dos serviços de saúde materno-infantil, onde a cobertura atingida pela assistência pré-natal foi de $61,6 \%$, independente do número de consultas realizadas.

Tabela 7. Distribuição das características da assistência pré-natal. Comunidades Terena, MS, Brasil, 1999.

\begin{tabular}{lcc}
\hline VARIÁVEIS & TOTAL & $\%$ \\
Assistência pré-natal & & \\
Sim & 218 & 61,6 \\
Não & 136 & 38,4 \\
Número de consultas pré-natal & & \\
$1-3$ & 79 & 36,2 \\
$4-6$ & 82 & 37,6 \\
$7-9$ & 52 & 23,9 \\
+9 & 5 & 2,3 \\
Início da atenção pré-natal & & \\
$1^{\circ}$ Trimestre & 104 & 47,7 \\
$2^{\circ}$ Trimestre & 76 & 34,9 \\
$3^{\circ}$ Trimestre & 38 & 17,4 \\
& & \\
\hline
\end{tabular}


$\mathrm{Na}$ análise do número de consultas $36,2 \%$ das mulheres realizaram de 1 a 3 consultas, $37,6 \%$ de 4 a 6 consultas, $23,9 \%$ de 7 a 9 consultas e $2,3 \%$ realizaram mais de 9 consultas. O número médio de consultas foi 5,6, com desvio padrão de 2,4 consultas. Quanto ao início do atendimento $47,7 \%$ das mulheres iniciaram o atendimento no primeiro trimestre de gestação, $34,9 \%$ no segundo trimestre e $17,4 \%$ no terceiro trimestre. As Figuras 27, 28 e 29 evidenciam associações entre a realização de pré-natal e a localização do domicílio, educação materna e renda.

Figura 27. Distribuição percentual da assistência pré-natal. Comunidades Terena, MS, Brasil, 1999.

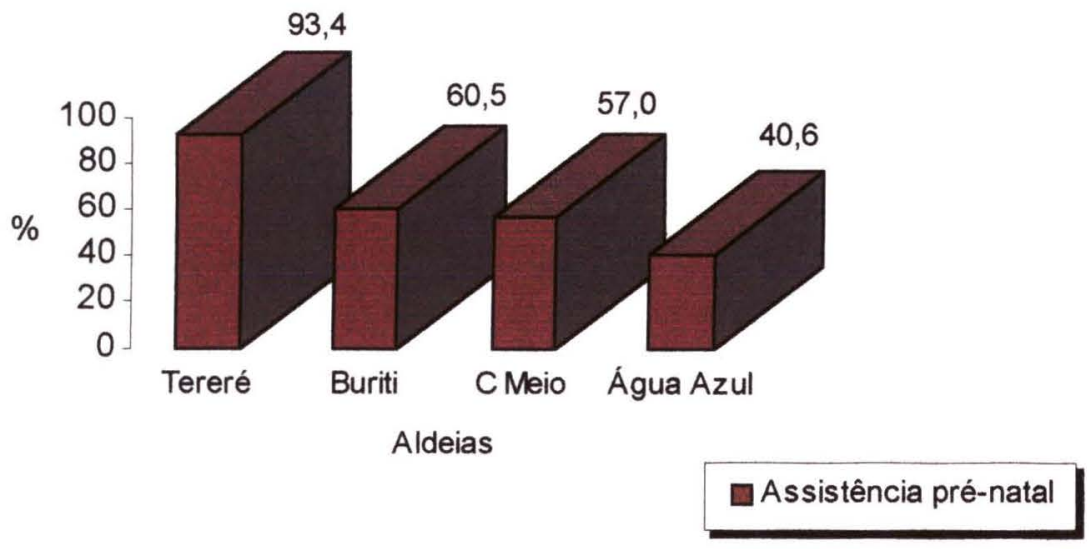

As mulheres residentes na Aldeia Tereré obtiveram maior assistência $(93,4 \%)$. Entre as mulheres sem escolaridade mais da metade não havia recebido nenhuma assistência pré-natal. A assistência era adequada nas famílias de maior renda. 
Figura 28. Distribuição percentual da assistência pré-natal segundo escolaridade materna. Comunidades Terena, MS, Brasil, 1999.

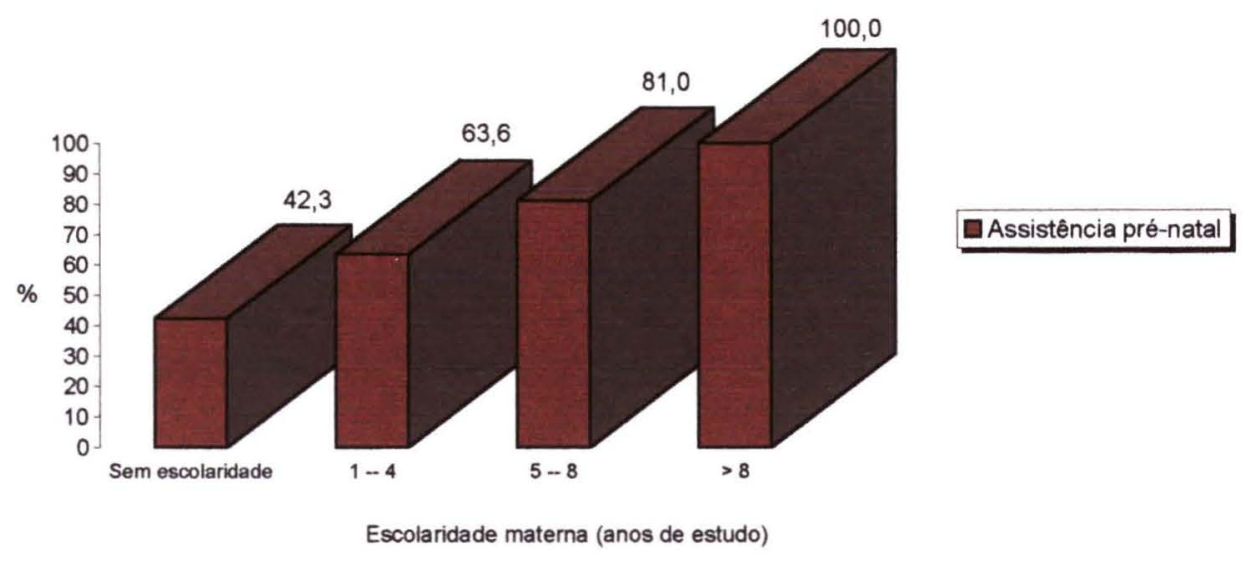

Figura 29. Distribuição percentual da assistência pré-natal segundo a renda per capita familiar. Comunidades Terena, MS, Brasil, 1999.

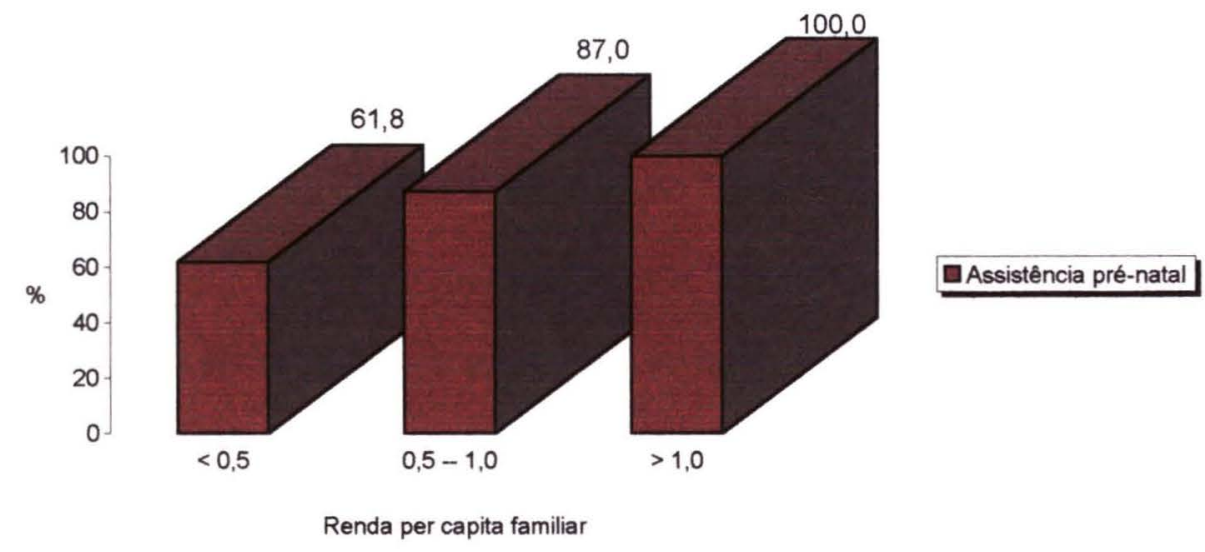

A Tabela 8 apresenta as características do nascimento nas comunidades Terena onde, a cobertura de assistência ao parto apresentou 71,8\% assistidos em hospitais, com freqüência de $15,8 \%$ de partos operatórios. 
Tabela 8. Distribuição das características das condições de nascimento. Comunidades Terena, MS, Brasil, 1999.

\begin{tabular}{lcc}
\hline VARIÁVEIS & TOTAL & $\%$ \\
\hline $\begin{array}{l}\text { Local do parto } \\
\text { Domićlio }\end{array}$ & 100 & \\
Hospital & 254 & 28,2 \\
Tipo de parto & & 71,8 \\
Normal & 298 & \\
Operatório & 56 & 84,2 \\
Peso ao nascer (gramas) & & 15,8 \\
2500 & & \\
$2501-3000$ & 24 & 12,5 \\
$3001-3500$ & 45 & 23,4 \\
$3501-4000$ & 75 & 39,1 \\
$>4000$ & 41 & 21,4 \\
& 7 & 3,6 \\
\hline
\end{tabular}

Considerando as 192 crianças que tinham informações do peso ao nascer observou-se $12,5 \%$ com baixo peso $(\leq 2500 \mathrm{~g}), 35,9 \%$ igual ou inferior a $3000 \mathrm{~g} \mathrm{e}$ $64,1 \%$ com peso ao nascer acima de $3000 \mathrm{~g}$. É importante observar que este índice pode estar subestimado, considerando que $45,8 \%$ das crianças não tinham registro do peso ao nascer, representado especialmente pelas crianças nascidas em domicílios, possivelmente as de maior risco.

A Figura 30 ilustra a distribuição percentual do local de parto das mulheres estudadas, segundo as diferentes comunidades, com destaque para o elevado número de partos domiciliares nas Aldeias Água Azul e Córrego do Meio. 
Figura 30. Distribuição percentual do local de realização do parto. Comunidades Terena, MS, Brasil, 1999.
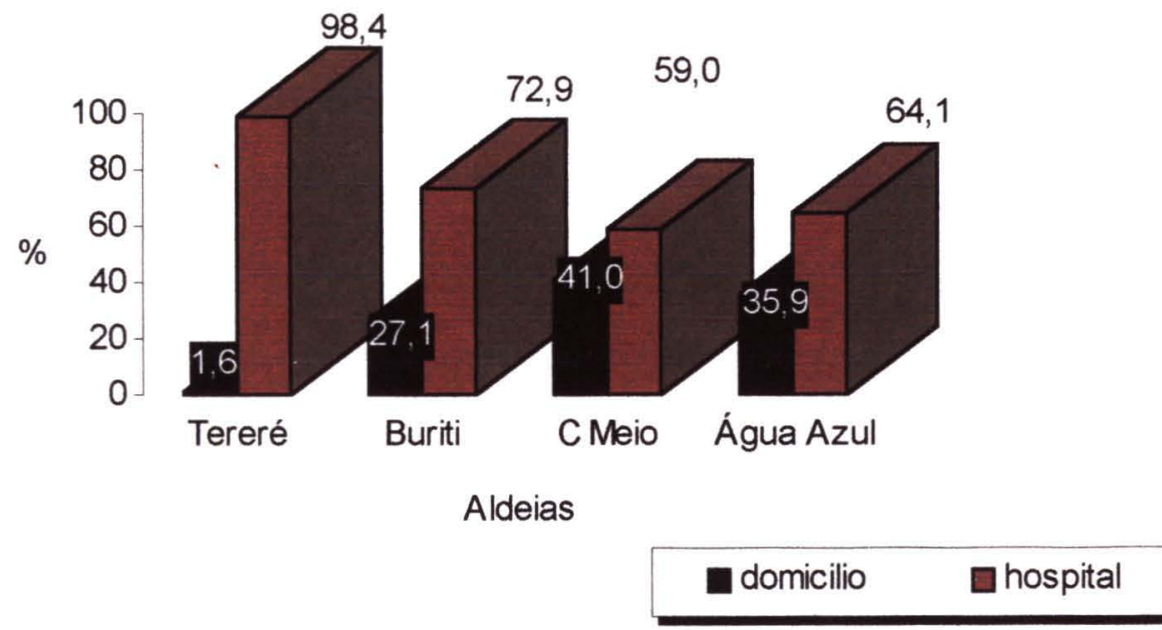

A Figura 31 ilustra a distribuição percentual do tipo de parto das mulheres sendo observado o elevado número de partos operatórios na Aldeia Tereré.

Figura 31. Distribuição percentual do tipo de parto. Comunidades Terena, MS, Brasil, 1999.
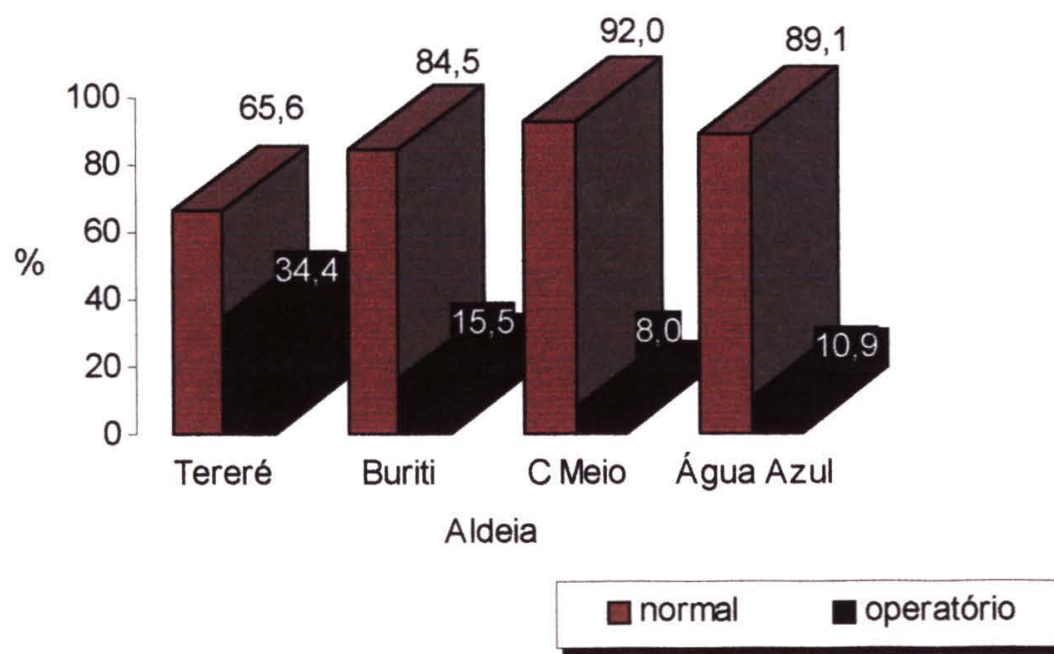
A Figura 32 apresenta a distribuição percentual do peso ao nascer das crianças estudadas nas diferentes comunidades, com elevada freqüência de baixo peso ao nascer $(\leq 2500 \mathrm{~g})$ nas Aldeias Córrego do Meio e Água Azul.

Figura 32. Distribuição percentual do baixo peso ao nascer de crianças indígenas. Comunidades Terena, MS, Brasil, 1999.

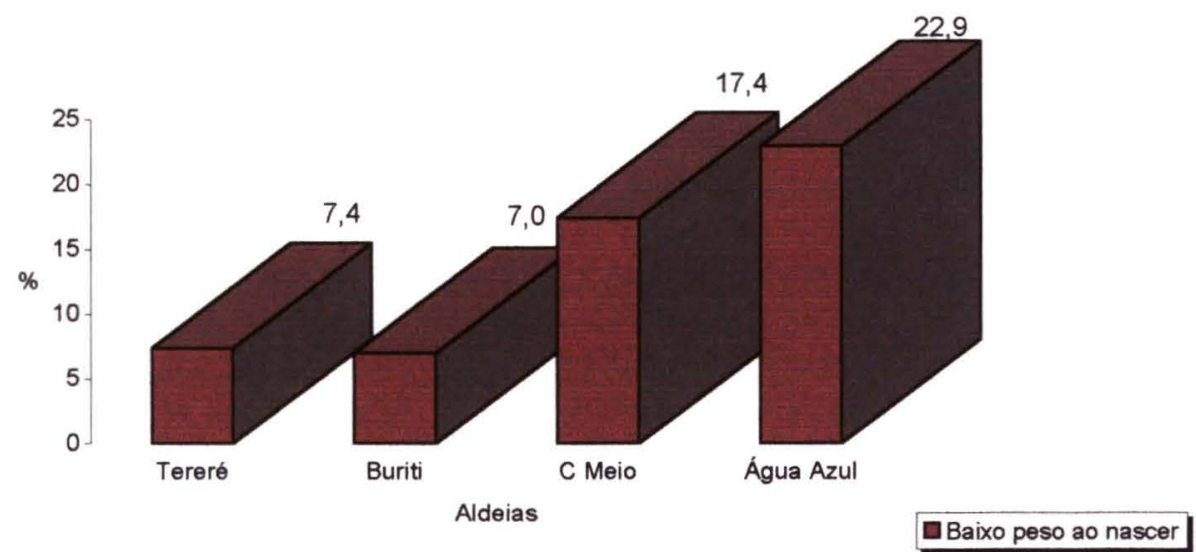

A Tabela 9 apresenta as ações básicas do programa de atenção integral à saúde da criança onde, na cobertura de assistência médica e a vigilância do crescimento infantil nos últimos seis meses anteriores a pesquisa, 37,3\% referiu freqüência a serviços de assistência médica (pelo menos uma consulta médica) e 14,7\% a realização da atividade de vigilância do crescimento infantil com agentes de saúde.

No período de análise os agentes indígenas de saúde aguardavam o treinamento sobre a operacionalização do sistema de vigilância do crescimento e os instrumentos necessários para o desenvolvimento dos trabalhos. 
Tabela 9. Distribuição das ações básicas do programa de atenção integral à saúde da criança. Comunidades Terena, MS, Brasil, 1999.

\begin{tabular}{lrr}
\hline VARIÁVEIS & TOTAL & $\%$ \\
\hline Vigilância do crescimento & & \\
Sim & 52 & 14,7 \\
Não & 302 & 85,3 \\
Consulta médica (últimos 6 meses) & & \\
Sim & 132 & 37,3 \\
Não & 222 & 62,7 \\
Imunização & & \\
Calendário de vacinação completo & 268 & 75,7 \\
Calendário de vacinação com atraso & 72 & 20,3 \\
Não recebeu nenhuma vacina & 14 & 4,0 \\
\hline
\end{tabular}

A Figura 33 apresenta a distribuição percentual da vigilância do crescimento infantil, segundo as diferentes comunidades, onde a Aldeia Tereré apresenta melhores percentuais de realização desta atividade de monitoramento.

Figura 33. Distribuição percentual da vigilância do crescimento das crianças menores de cinco anos. Comunidades Terena, MS Brasil, 1999.

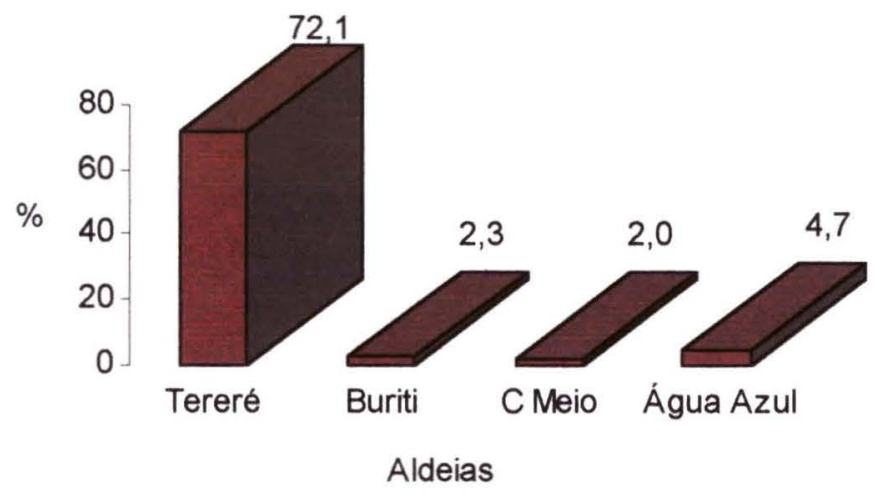

vigilância do crescimento 
De acordo com a Tabela 9 a avaliação da cobertura vacinal, em crianças maiores de 1 ano apresentou, 81,2\% de cumprimento ao esquema básico de vacinação e 75,7\% para o total da amostra, independente da idade. Na distribuição da cobertura segundo a localização do domicílio foram observados maiores percentuais na Aldeia Tereré e piores na Água Azul, conforme ilustra a Figura 34.

Figura 34. Distribuição percentual da cobertura vacinal em crianças indígenas menores de cinco anos. Comunidades Terena, MS Brasil, 1999.

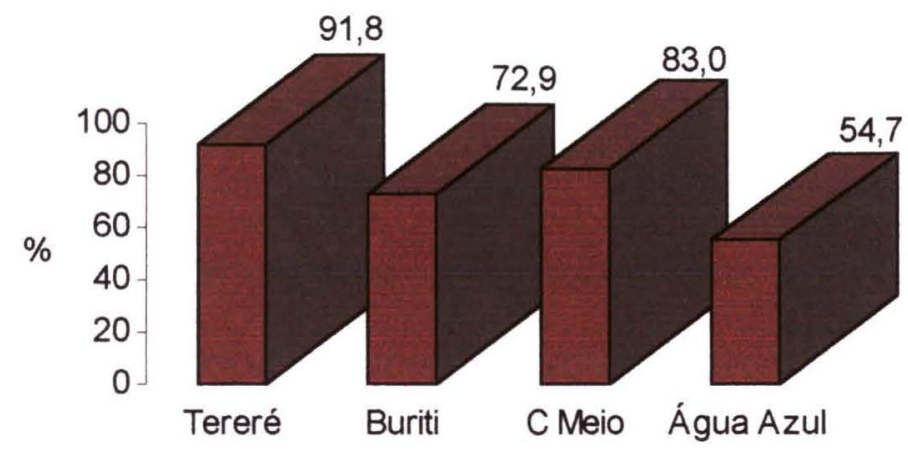

Aldeias

cobertura vacinal

\subsubsection{Morbidade e Internações Hospitalares}

A informação da morbidade foi obtida mediante a percepção dos pais acerca de sinais e sintomas, indicadores de patologias em seus filhos no período da entrevista. Não foram investigadas as relações de correspondência direta da percepção dos pais com diagnósticos biomédicos. Vale enfatizar que muitos pais referiam problemas dermatológicos e digestivos como eventos normais, não constituindo uma manifestação patológica.

Como o observado por BUCHILLET (1991) em populações indígenas da Amazônia, o sistema Terena de interpretação de uma doença inclui um "primeiro 
diagnóstico que é estabelecido pelo paciente, sua família ou a comunidade, diagnóstico baseado tanto na observação das manifestações patológicas da doença, como na consideração de elementos que presidiram sua aparição" (p.28). Isto foi verificado em diversos momentos das entrevistas onde, a equipe identificava indivíduos doentes, que já haviam sido diagnosticados pela família, estavam recebendo tratamento à base de ervas e orações de uma "avó tronco" mas que ainda seria levado ao serviço de saúde do município vizinho, a fim de ser avaliado por um médico.

De acordo com a Tabela 10 , doenças foram referidas em $47,5 \%$ das crianças estudadas sendo, $56,5 \%$ das crianças com doenças respiratórias (bronquite, pneumonia, infecções das vias aéreas superiores); $20,8 \%$ com doenças digestivas (diarréia, vômito), 6,0\% com patologias dermatológicas (eczema, dermatite, micoses, tinhas da pele, impetigo); 4,2\% com doenças do sistema nervoso (crises epilépticas); $1,8 \%$ com doenças parasitárias (parasitoses intestinais); $1,2 \%$ com patologias congênitas (defeitos esqueléticos e defeitos oculares) e 9,5\% com outras afecções (acidentes, conjuntivite, desnutrição, anemia, corrimento vaginal e otite).

Tabela 10. Distribuição proporcional de enfermidades em crianças indígenas Terena, MS, Brasil, 1999.

VARIÁVEIS

Presença de enfermidades

Sim

Não

Enfermidades referidas

Doenças respiratórias

Doenças digestivas

Doenças dermatológicas

Doenças do sistema nervoso

Doenças parasitárias

Doenças congênitas

Outras afeções

Ocorrência de diarréia

Diarréia no dia da entrevista

Diarréia nos últimos quinze dias
TOTAL $\%$

$\begin{array}{rr}168 & 47,5 \\ 186 & 52,5 \\ & \\ 95 & 56,5 \\ 35 & 20,8 \\ 10 & 6,0 \\ 7 & 4,2 \\ 3 & 1,8 \\ 2 & 1,2 \\ 16 & 9,5 \\ & \\ 35 & 9,9 \\ 94 & 26,6\end{array}$


A Figura 35 apresenta a distribuição percentual de morbidade infantil referida pelos pais, segundo as comunidades estudadas, onde a freqüência aumenta à medida que se distancia dos recursos de assistência à saúde e de saneamento básico.

Figura 35. Distribuição percentual de enfermidades em crianças menores de cinco anos. Comunidades Terena, MS, Brasil, 1999.

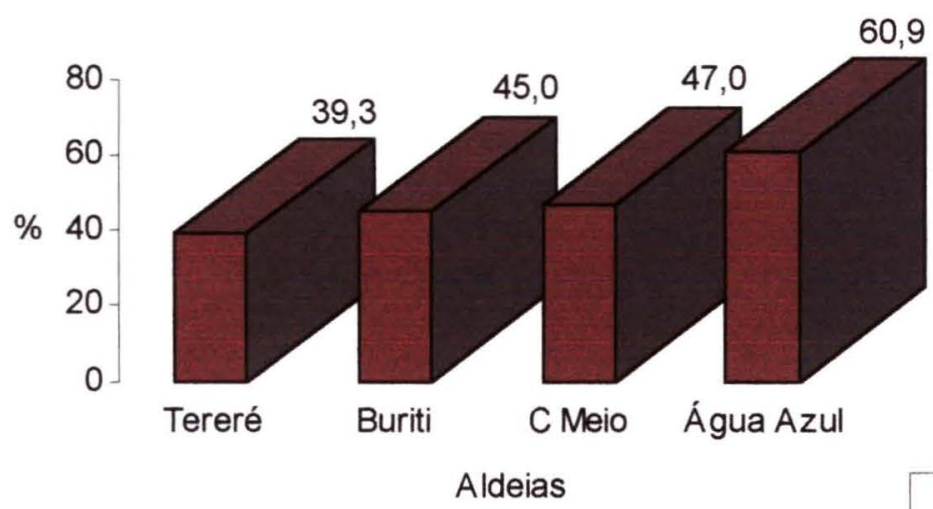

Morbidade

A prevalência de diarréia no dia da entrevista foi de $9,9 \%$ do total estudado. Foi investigada ainda a ocorrência de diarréia nos quinze dias anteriores ao dia da entrevista sendo observado, 26,6\%, com maior freqüência nas crianças de 6 a 11 meses e apresentando decréscimo significativo após os 35 meses de idade.

Com relação as internações hospitalares nos seis meses anteriores à pesquisa, $9,6 \%$ foram internadas, destas, $44,1 \%$ foram determinadas por diarréia e $41,1 \%$ por infecções respiratórias.

\subsubsection{Alimentação Infantil}

Para a avaliação do consumo alimentar foram amostradas 140 crianças menores de cinco anos. Entre as crianças menores de 6 meses (11) foram observadas três crianças que já recebiam alimentos semi-sólidos. Esses alimentos eram oferecidos sob a forma de sopas, constituídas basicamente de arroz e macarrão. A adição de feijão na sopa era esporádica e, somente o caldo. Quanto à consistência, as sopas eram oferecidas inicialmente diluídas, passando à forma de pirão com a 
evolução da idade da criança. A introdução de carnes foi observada em $25,0 \%$ das crianças com 6 a 12 meses, não sendo identificada nenhuma restrição cultural ao consumo, apenas a baixa disponibilidade do alimento no domicílio por questões econômicas. No preparo das mamadeiras de leite integral de vaca, presente apenas em $7,0 \%$ das dietas infantis, foram verificados em $85,0 \%$ a adição de açúcar e em $8,0 \%$ a utilização de espessantes, como fubá de milho e farinha de mandioca. Derivados do leite (iogurte) foram identificados em $0,8 \%$ das dietas.

As crianças acima de um ano, assim como os adultos, faziam três refeições, relatadas como principais, sem horários rígidos mas distribuídas ao longo do dia sendo, a primeira ao acordar, no nascer do sol, a segunda no meio do dia e a terceira no início da noite, quando o sol se põe.

$\mathrm{Na}$ maioria dos domicílios não existem mesas, os pratos são servidos diretamente da panela e os indivíduos sentam em bancos espalhados pela varanda ou em troncos de árvores, apoiando o prato nas mãos. Os adultos comem devagar e silenciosamente.

Estando pronta a refeição qualquer elemento pode servir o próprio prato, não é necessário esperar todos estarem presentes. Normalmente as crianças servem-se primeiro e têm autonomia na escolha do alimento a ser consumido. Sentam no colo dos pais, bancos ou no chão, especialmente quando os bancos são insuficientes para todos os moradores. Os talheres disponíveis são garfo e colher. Qualquer membro da família pode oferecer do próprio prato, alimento para as crianças menores de um ano. Normalmente a mãe, avó ou irmãos mais velhos realizam esta tarefa. A partir desta idade a criança se alimenta sozinha, utilizando as mãos.

Não são deixados restos nos pratos, tudo que é servido é consumido. Após as refeições, quando sobram alimentos preparados, eles permanecem nas panelas sobre o fogão, com livre acesso para qualquer elemento voltar a servir.

A varanda é o local privilegiado do domicílio, onde as refeições se realizam, recebem as visitas, armam a rede, brincam, contam e ouvem histórias. A casa pode ter um único dormitório, mas nunca sem varanda.

A primeira refeição do dia era constituída de arroz e mandioca cozidos, geralmente sobras da véspera. Para as crianças era também oferecido chá mate com 
açúcar, bolo de arroz (assado na panela) ou simplesmente água com açúcar caramelizado.

No almoço e jantar foram acrescidos o feijão cozido, macarrão cozido (sem molho) e a carne frita. $\mathrm{O}$ arroz e a mandioca eram os alimentos mais freqüentes e em maior quantidade nas refeições, sendo muitas vezes os únicos.

A presença da carne bovina é bastante valorizada na refeição, mas de difícil acesso para a maioria das famílias e, quando presente $(39,5 \%)$, são as de menor custo, com elevado teor de gordura como por exemplo, costela e ponta de peito. Para os Terena as carnes devem ser gordas, sendo consideradas as mais saborosas.

Quanto à forma de preparo das carnes e ovos, há predomínio de frituras. As frituras também são utilizadas como meio de conservação, uma vez que as carnes são fritas quando adquiridas, sendo guardadas em latas, submersas em gordura animal.

O consumo de aves (galinha/frango) ocorre em ocasiões especiais, sendo observado em apenas 3,7\% das dietas. Com relação aos ovos foram observados em $6,9 \%$ das dietas analisadas. Nas festas são oferecidos carne bovina assada e servida em longos espetos de madeira, puchero e mandioca cozida.

Quanto ao consumo de vegetais, das 129 crianças com idade acima de seis meses, $2,3 \%$ consumiram verduras, tais como couve, maxixe e tomate. $\mathrm{O}$ consumo de legumes e tubérculos foi de $53,5 \%$, representado especialmente por mandioca, batata doce e abóbora. A mandioca é considerada alimento de todas as horas e de todos os dias, permitindo preparar diversos pratos como o lapâpé (beijú), hîhi (bolo de mandioca cozido na água), xupú (massa de mandioca cozida e socada no pilão) e o pôréo (creme de mandioca). A produção de farinha de mandioca é responsabilidade das mulheres de cada família, tarefa árdua de descascar, ralar, lavar a massa, espremer, torrar, podendo levar horas ou dias, dependendo da quantidade da matéria prima. As mulheres só descansam quando toda a mandioca estiver ralada. A farinha produzida é armazenada em sacos de algodão, por longos períodos, sendo motivo de orgulho familiar e objeto de permuta ou presente a ser oferecido aos parentes e amigos.

Nas refeições intermediárias havia consumo de frutos (há 'itikoti) coletados ao redor do domicílio, água com açúcar caramelizado ou tubérculos (mandioca e/ou batata doce) cozidos ou assados. 
O consumo de frutas era restrito à disponibilidade das mesmas na área, sendo observado apenas $1,4 \%$ de dietas com frutas adquiridas em estabelecimento comercial. A banana era a fruta mais freqüente, cultivada próxima dos domicílios e oferecida a parentes e visitantes. Nas dietas analisadas, 9,3\% tinham suco natural de fruta (limão) e 6,4\% sucos artificiais (pó).

Os pomares não apresentavam demarcações, com livre acesso para todos os integrante da aldeia. Quanto aos frutos presentes, observou-se o consumo de manga, mamão, abacaxi, limão e goiaba em alguns meses do período compreendido pelo estudo. Dentre os frutos coletados na mata circunvizinha foram identificados a bocaiúva (Acrocomia aculeata) e o araticum (Anona coriaceae). Outras árvores frutíferas, como laranja, tangerina, tamarindo, maracujá, abacate, jabuticaba, acerola e caju foram identificados, mas sem produção de frutos no período.

Quanto ao consumo de produtos industrializados foram identificados o açúcar, sal, óleo de soja, macarrão, café, farinha de trigo, leite em pó, extrato de tomate, refresco em pó, chá, refrigerante (guaraná), lingüiça, bala, pão francês e biscoitos. Esses produtos estavam presentes principalmente na dieta das famílias que dispunham de aposentadoria ou salário, sendo adquiridos no período de recebimento. Não foram investigadas restrições e proibições alimentares, nem mesmo as relações simbólicas entre alimentos e indivíduos.

Nas roças foi identificado o cultivo de arroz, feijão, mandioca, banana e milho e em algumas delas também a batata doce, abóbora, maxixe, quiabo, abacaxi, melancia, amendoim e cana de açúcar, variando de acordo com a área e a época do ano. A diversidade de produtos cultivados não garante o consumo adequado dos mesmos, seja pela quantidade produzida, pela necessidade de comercializar ou pela ausência de um sistema de armazenamento e conservação dos produtos. Os homens possuem conhecimentos dos fenômenos climáticos e dos ciclos das temporadas de chuvas e secas, auxiliando no planejamento das roças.

Quanto à criação de animais, 73,6\% das famílias criavam animais, sendo que $73,6 \%$ tinham aves (galinha), 19,8\% suínos e 3,3\% bovinos, em pequena escala.

A caça e a pesca são atividades individuais ou coletivas, realizadas esporadicamente pelos homens, com dificuldades, devido à limitação territorial da área na reserva, além de outros problemas relacionados à subsistência do grupo, 
como invasões de suas terras, dispersão e escassez de animais e contaminação dos rios. Todas as cabeceiras de rios que banham a terra dos Terena estão fora da área demarcada, atravessando grandes extensões de fazendas que ficam ao redor da área indígena e onde a proteção da mata ciliar não é respeitada, causando gradativamente, o assoreamento destes rios. Com relação à pesca, $40,1 \%$ realizaram esta atividade, $22,2 \%$ caçavam e $24,5 \%$ coletavam frutos silvestres.

A Tabela 11 apresenta o consumo médio de energia e nutrientes, segundo a idade, onde o consumo de energia é insuficiente em todos os grupos etários.

$\mathrm{Na}$ análise da freqüência de alimentos da dieta familiar observou-se predomínio de alimentos ricos em carboidratos simples (açúcar, macarrão, pães e biscoitos) e gorduras de origem animal (carnes gordas), mas em quantidades abaixo das recomendações.

Tabela 11. Distribuição da média do consumo de energia e nutrientes segundo a idade. Comunidades Terena, MS, Brasil, 1999.

\begin{tabular}{|c|c|c|c|c|}
\hline \multirow{2}{*}{ NUTRIENTES } & \multicolumn{4}{|c|}{ IDADE $^{*}$ (meses) } \\
\hline & $0 \vdash 6$ & $6 \vdash 12$ & $12 \vdash 36$ & $36 \vdash 60$ \\
\hline Energia (kcal) & 457,9 & 461,2 & 678,8 & 727,0 \\
\hline Proteína (g) & 11,2 & 11,3 & 22,0 & 27,0 \\
\hline Carboid rato (g) & 46,9 & 63,2 & 104,2 & 115,8 \\
\hline Lipídeo (g) & 27,4 & 19,0 & 19,6 & 17,1 \\
\hline Vitamina A ( $\mu \mathrm{g}$ RE) & 347,4 & 279,8 & 193,6 & 172,1 \\
\hline Vitamina $\mathrm{C}$ & 27,8 & 33,6 & 29,5 & 41,9 \\
\hline Ferro (mg) & 0,7 & 2,2 & 4,0 & 5,1 \\
\hline Cálcio (mg) & 374,8 & 228,9 & 220,0 & 165,6 \\
\hline
\end{tabular}

* 140 crianças menores de cinco anos 
Dentre os frutos ricos em vitamina $\mathrm{C}$ e $\mathrm{A}$, foi verificada a presença de mamão, limão, e tomate (vitamina $\mathrm{C}$ ) nos meses de julho a dezembro e manga e bocaiúva (vitamina A), somente no último mês do estudo (dezembro).

A Figura 36 apresenta a média do consumo energético comparado com as recomendações da $10^{\mathrm{a}}$ Recommended Dietary Allowances (RDA 1989). O consumo de energia é insuficiente em todas as idades, especialmente na dieta das crianças acima de 1 ano de idade.

Figura 36. Distribuição comparativa do consumo de energia da dieta infantil e as recomendações da $10^{\mathrm{a}} \mathrm{RDA}$.

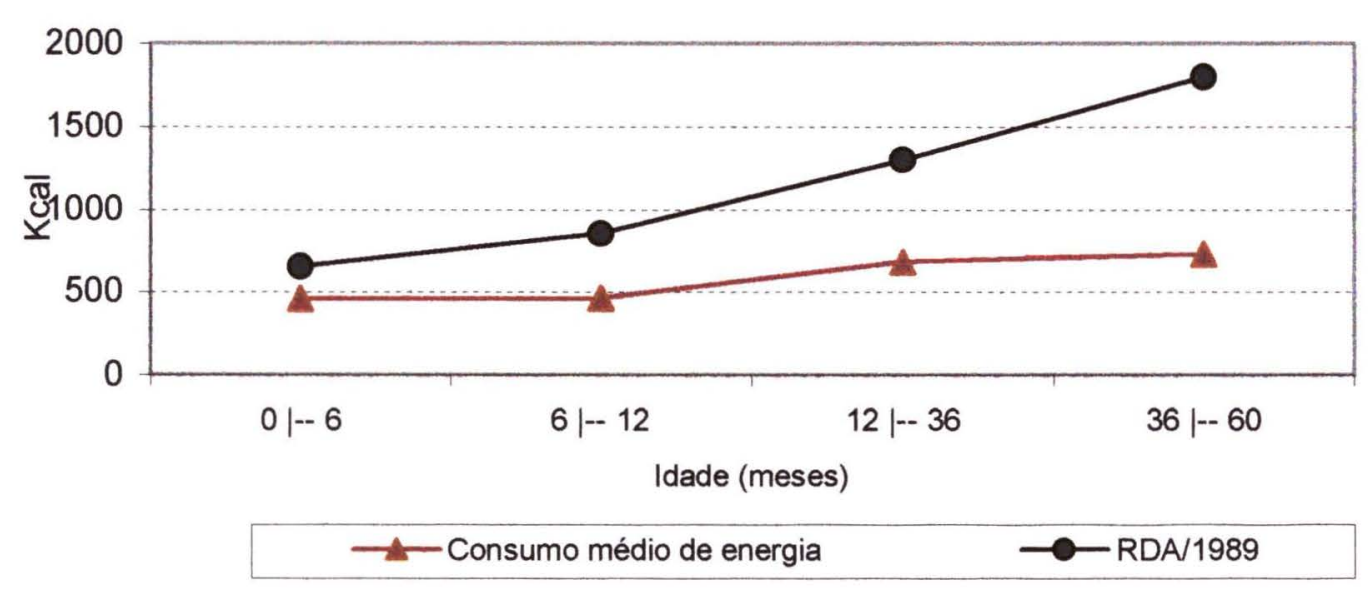

O consumo médio de proteína era insuficiente na dieta das crianças menores de 1 ano, ultrapassando as recomendações para as demais crianças, conforme ilustra a Figura 37. 
Figura 37. Distribuição comparativa do consumo de proteína da dieta infantil e as recomendações da $10^{\mathrm{a}} \mathrm{RDA}$.

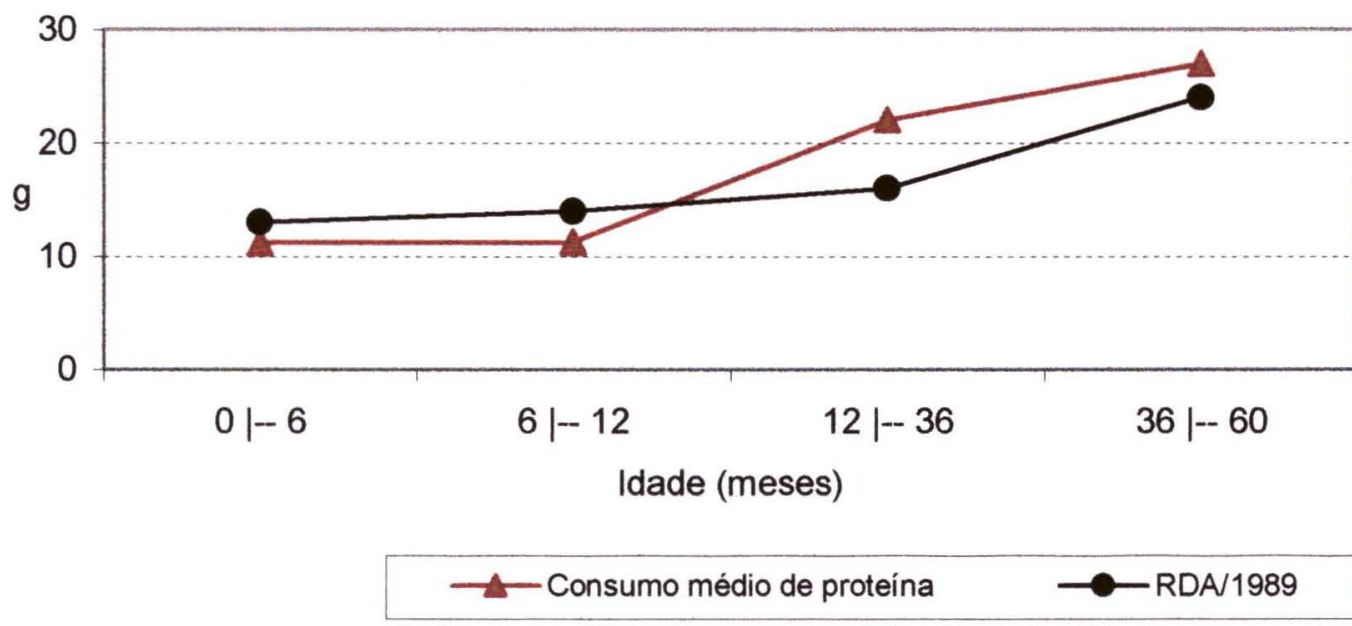

O consumo médio de vitamina A não atinge as recomendações nas diferentes idades, com tendência à piora nas idades subseqüentes, conforme ilustra a Figura 38.

Figura 38. Distribuição comparativa do consumo de vitamina A da dieta infantil e as recomendações da $10^{\mathrm{a}} \mathrm{RDA}$.

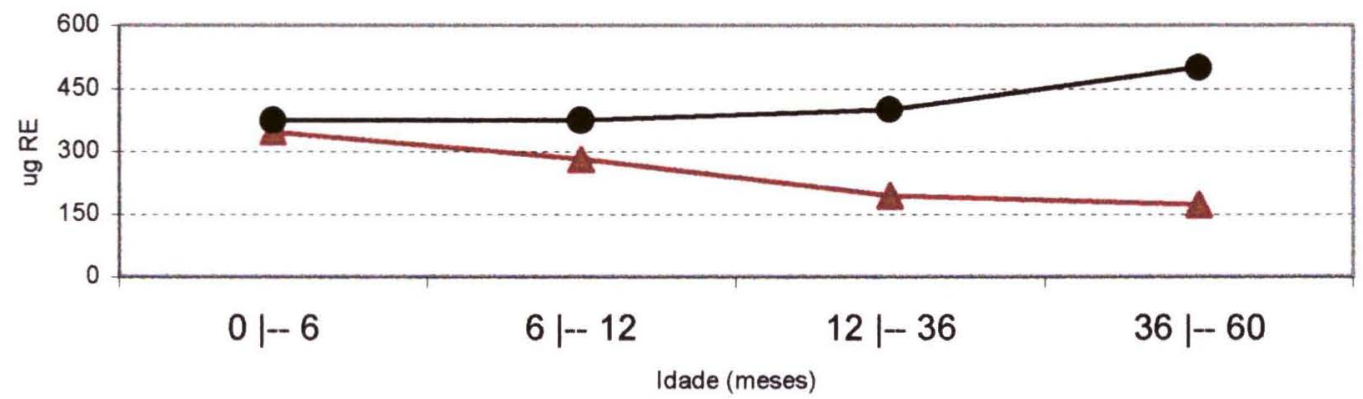

- Consumo médio de vitamina A RDA1989 
A Figura 39 apresenta o consumo médio de vitamina $C$, com valores próximos às recomendações no primeiro ano de vida, decréscimo de consumo no segundo ano e melhora a partir do terceiro.

Figura 39. Distribuição comparativa do consumo de vitamina $C$ da dieta infantil e as recomendações da $10^{\mathrm{a}} \mathrm{RDA}$.

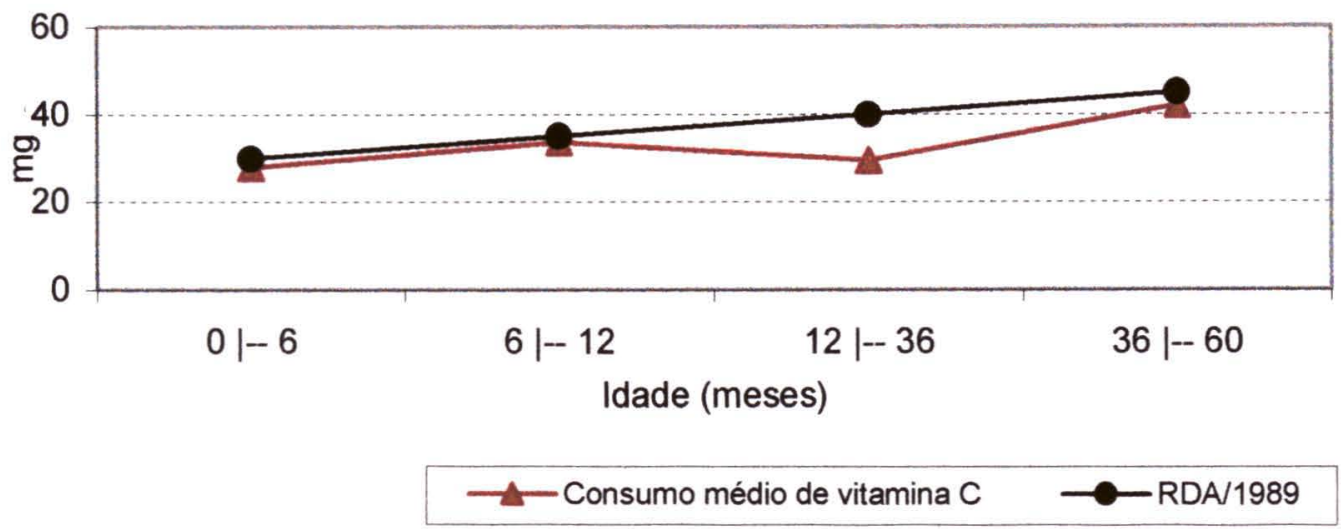

Em todas as idades, as dietas estavam deficientes no aporte de ferro, com valores muito abaixo das quantidades recomendadas, conforme ilustra a Figura 40.

Figura 40. Distribuição comparativa do consumo de ferro da dieta infantil e as recomendações da $10^{\mathrm{a}} \mathrm{RDA}$.

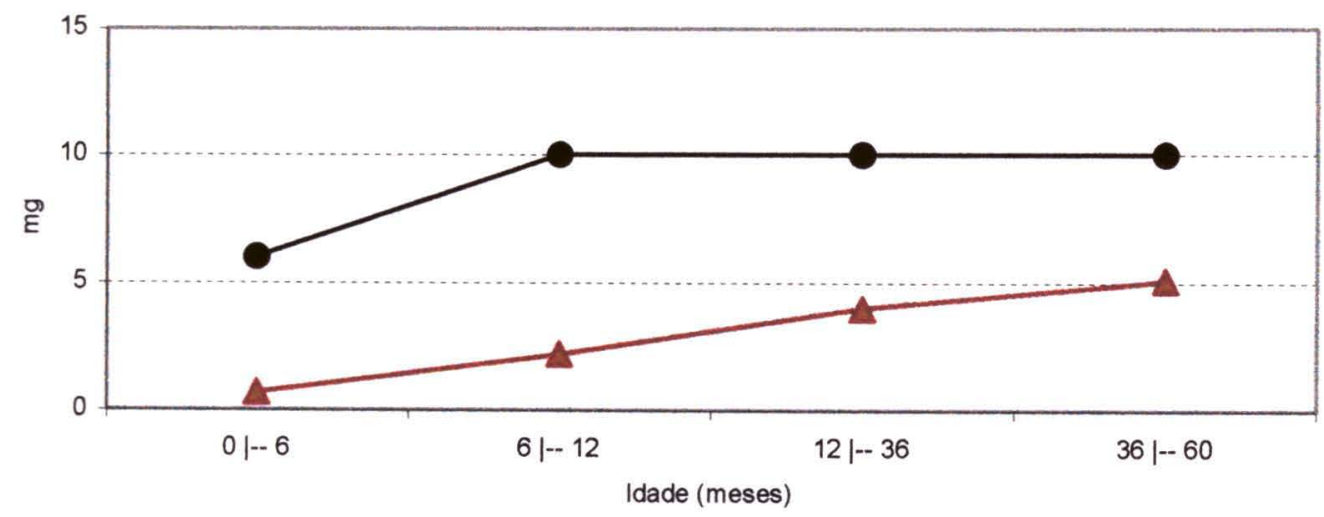

$\longrightarrow$ Consumo médio de ferro $\longrightarrow$ RDA1989 
De acordo com a Figura 41 o consumo médio de cálcio ultrapassa as recomendações das ingestões dietéticas de referência, somente na dieta das crianças menores de 6 meses, nos demais grupos etários a ingestão é insuficiente.

Figura 41. Distribuição comparativa do consumo de cálcio da dieta infantil e as recomendações da ingestão dietética de referência.

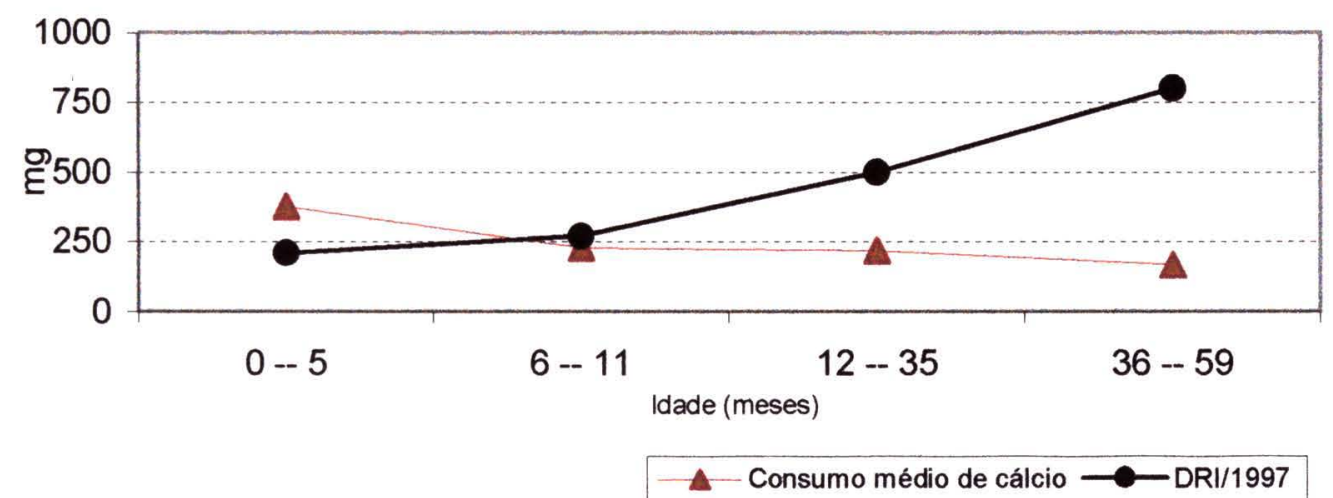

\subsubsection{Aleitamento Materno}

A Figura 42 apresenta a distribuição percentual do aleitamento materno geral, onde a totalidade das crianças iniciaram a amamentação, 93,8\% eram amamentadas aos 12 meses e $30,4 \%$ aos 24 meses de idade.

Figura 42. Distribuição percentual do aleitamento materno. Comunidades Terena, MS, Brasil, 1999.

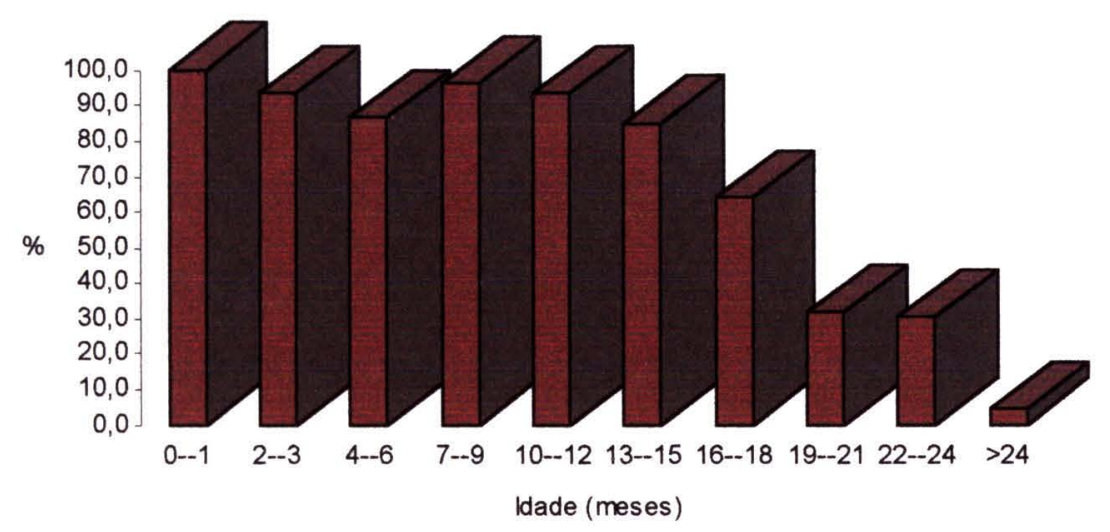

Aleitamento Materno 
A Tabela 12 apresenta a freqüência do aleitamento materno e suas modalidades, segundo a faixa etária das crianças.

Quanto ao aleitamento materno exclusivo em crianças menores de 6 meses, foi observada a prevalência de $21 \%$ no primeiro, $6,2 \%$ entre o segundo e terceiro mês. A partir do quarto mês, não foi observada nenhuma criança sendo alimentada exclusivamente com leite materno. A introdução de água e chás ocorreram ainda nos primeiros dias de nascido.

Tabela 12. Distribuição de freqüência da prática de aleitamento materno segundo a faixa etária. Comunidades Terena, MS, Brasil, 1999.

\begin{tabular}{lrrrr}
\hline $\begin{array}{c}\text { Faixa etária } \\
\text { (meses) }\end{array}$ & $\begin{array}{r}\text { Aleitamento } \\
\text { exclusivo }\end{array}$ & $\begin{array}{r}\text { Aleitamento } \\
\text { predominante }\end{array}$ & $\begin{array}{r}\text { Aleitamento } \\
\text { misto }\end{array}$ & $\begin{array}{r}\text { Crianças } \\
\text { amamentadas }\end{array}$ \\
\hline $0-1$ & 4 & 15 & - & 19 \\
$2-3$ & 1 & 14 & - & 15 \\
$4-6$ & - & 7 & 6 & 13 \\
$7-9$ & - & 10 & 15 & 25 \\
$10-12$ & - & - & 15 & 15 \\
$13-15$ & - & - & 17 & 17 \\
$16-18$ & - & - & 9 & 9 \\
$19-21$ & - & - & 7 & 7 \\
$22-24$ & - & - & 7 & 7 \\
$>24$ & - & - & 8 & 8 \\
\hline
\end{tabular}

Nos relatos de mães e avós verificou-se que, nos partos domiciliares a criança é levada ao seio nas primeiras horas de nascimento, permanecendo junto à mãe durante todo o tempo, enquanto familiares se ocupam das tarefas domésticas e do cuidado com os outros filhos. Mães que tiveram seus filhos em domicílios descrevem uma situação de coragem, alegria e amparo pela família.

Nas crianças que recebiam mamadeira foram observadas diluições incorretas do leite em pó, devido à falta de orientações e dificuldades de compreensão quanto às instruções de preparo fornecidas no rótulo dos produtos. 
A Figura 43 apresenta a distribuição percentual das crianças desmamadas segundo a idade.

Figura 43. Distribuição percentual das crianças indígenas desmamadas. Comunidades Terena, MS, Brasil, 1999.

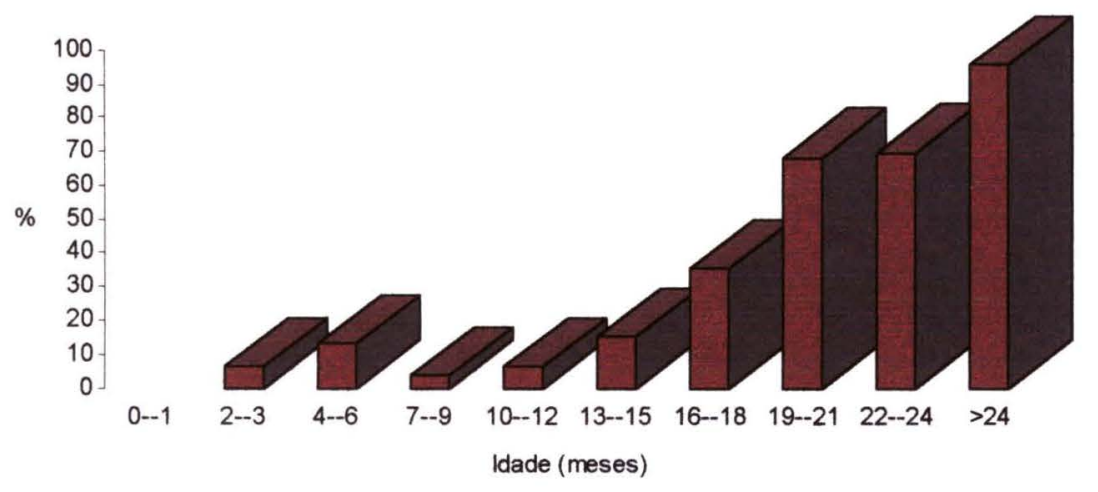

$\square$ Crianças desmamadas

Entre as crianças menores de seis meses já desmamadas, identificou-se uma com fissura labiopalatina, outra com mãe de mamilo invertido e uma terceira criança que a mãe acreditava não ter leite suficiente para alimentar seu filho. Com relação ao total de crianças menores de doze meses (86), foram observados 5,8\% de crianças desmamadas.

As mães são unânimes em afirmar que o aleitamento materno permanece enquanto a criança desejar ou é interrompido, caso engravidem. Para o grupo estudado o trabalho materno e a introdução de novos alimentos não consistiram fatores de desmame. $\mathrm{O}$ intervalo entre as gestações provavelmente estaria determinando a duração do aleitamento materno. 
A Figura 44 ilustra a distribuição percentual da prática de incentivo ao aleitamento materno desenvolvida por profissionais de saúde onde, $74 \%$ das mulheres não receberam orientações ou incentivos ao aleitamento, por profissionais de saúde, no período pré-natal e puerpério.

Figura 44. Distribuição percentual da prática de incentivo ao aleitamento materno. Comunidades Terena, MS, Brasil, 1999.

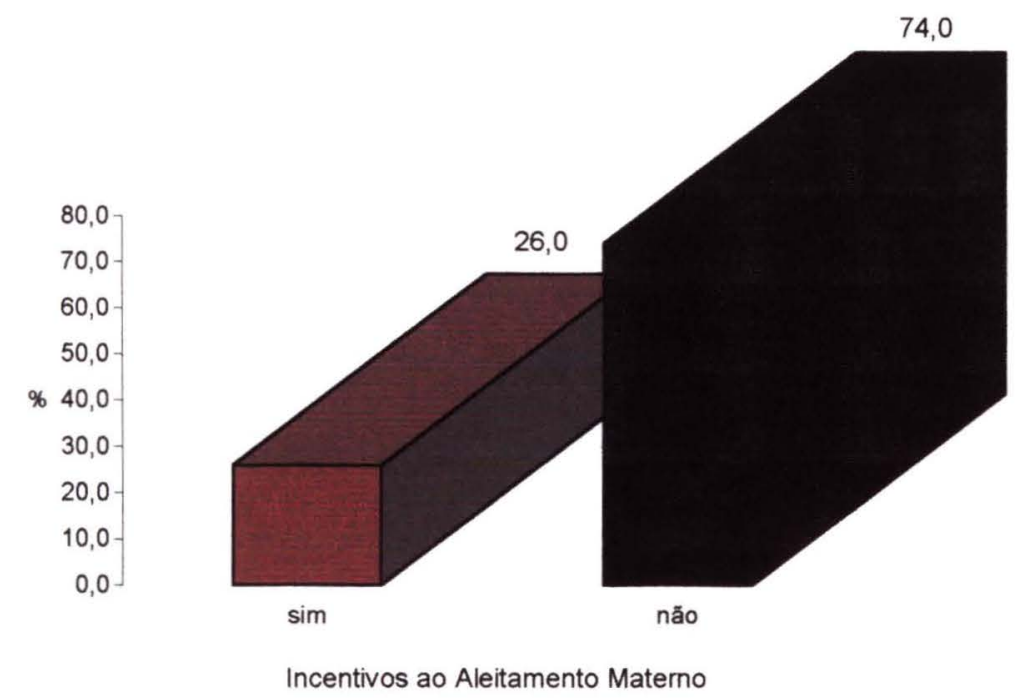

As Figuras 45 a 48 ilustram a distribuição percentual de aleitamento materno nas comunidades estudadas. Nota-se que todas apresentaram amamentação prolongada, especialmente a Aldeia Água Azul. 
Figura 45. Distribuição percentual de aleitamento materno segundo a idade. Aldeia Tereré, MS, 1999.

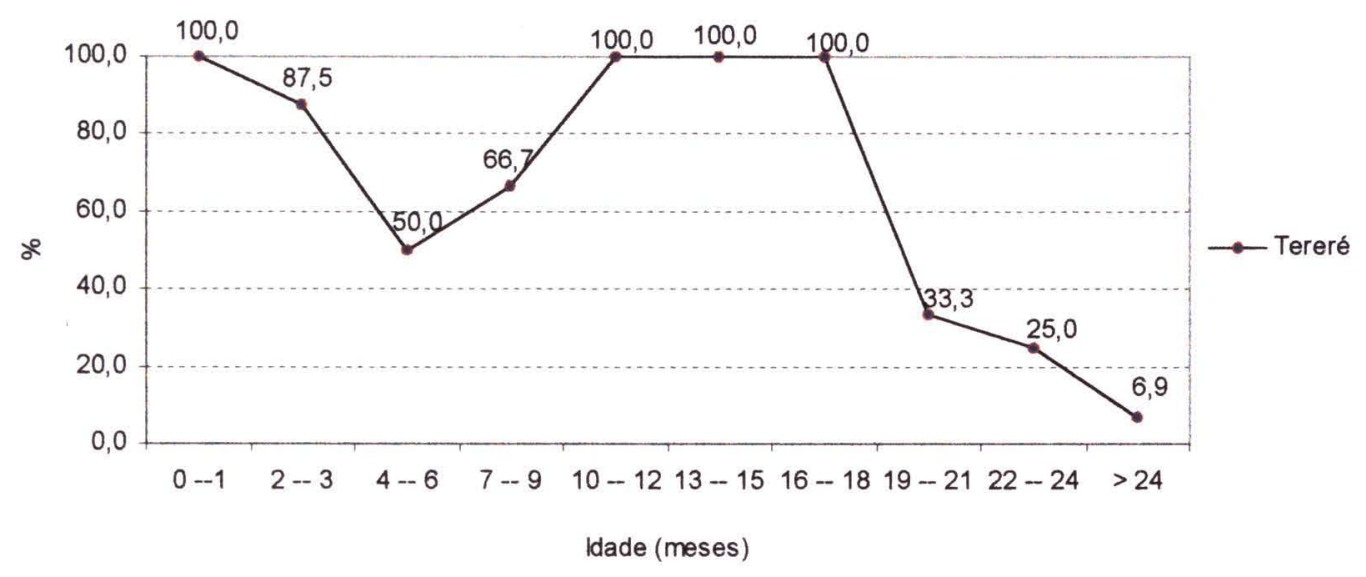

Figura 46. Distribuição percentual de aleitamento materno segundo a idade. Aldeia Buriti, MS, 1999.

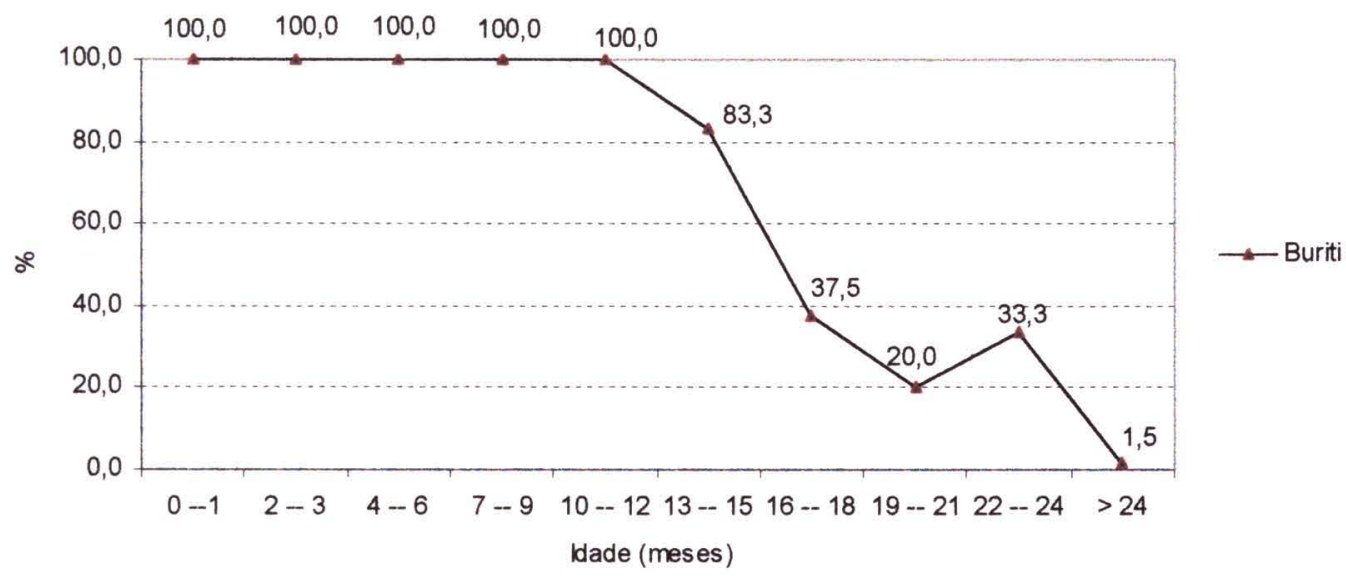


Figura 47. Distribuição percentual de aleitamento materno segundo a idade. Aldeia Córrego do Meio, MS, 1999.

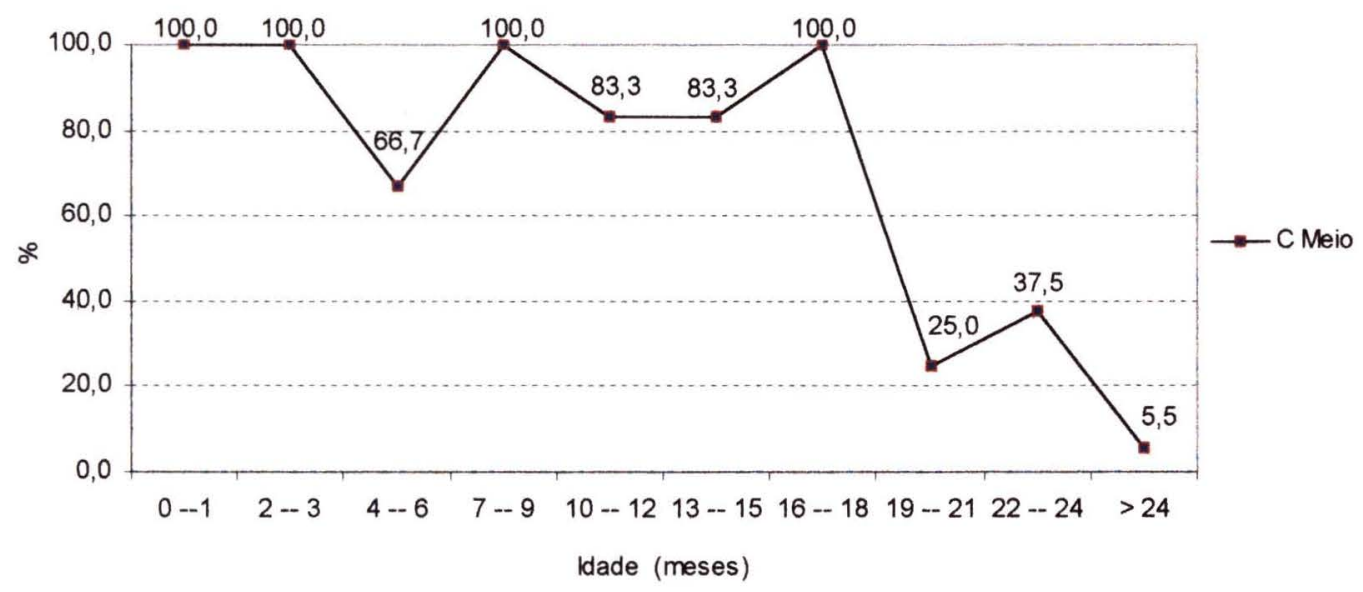

Figura 48. Distribuição percentual de aleitamento materno segundo a idade. Aldeia Água Azul, MS, 1999.

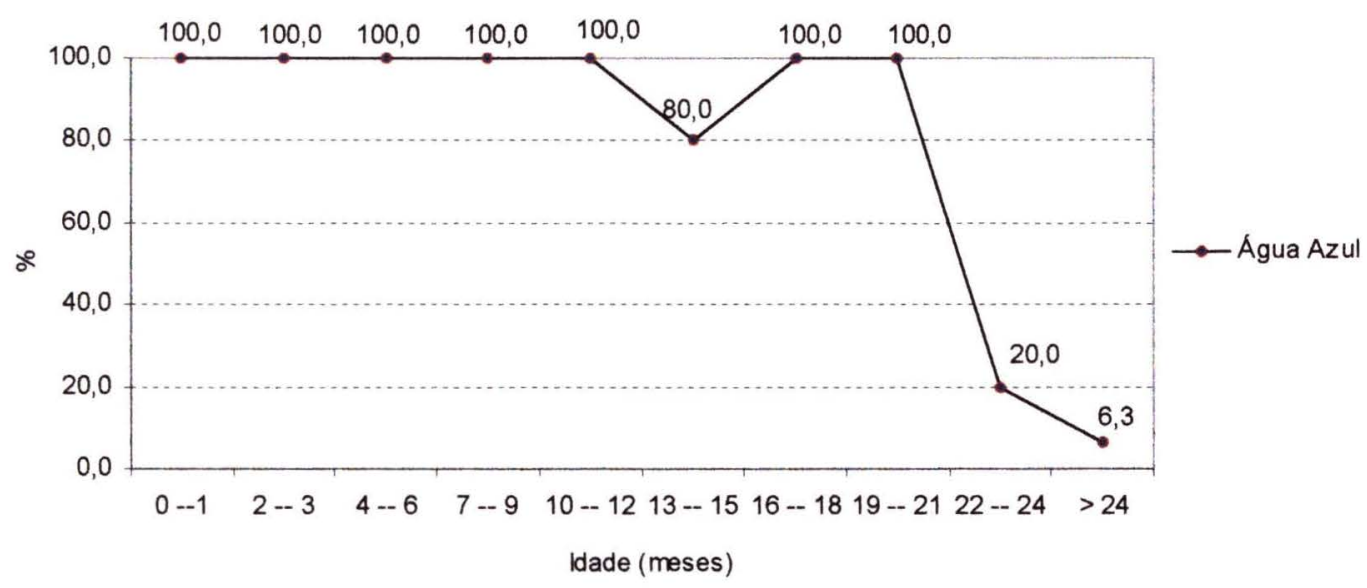




\subsubsection{Estado Nutricional}

A prevalência de déficits nutricionais ( $<-2$ z-escores) encontrados foram: 4,0\% para peso/idade; $11,1 \%$ para estatura/idade e 1,1\% para peso/estatura.

A Figura 49 ilustra a distribuição percentual do índice peso/idade apresentando média de -0,27 e 1,07 de desvio padrão, expresso em z-escore, em comparação com distribuição de referência NCHS/WHO (NCHS 1977). Nota-se que os valores obtidos são semelhantes aos valores de referência.

Figura 49. Distribuição percentual do índice peso/idade nas crianças indígenas menores de cinco anos e distribuição de referência NCHS/WHO.

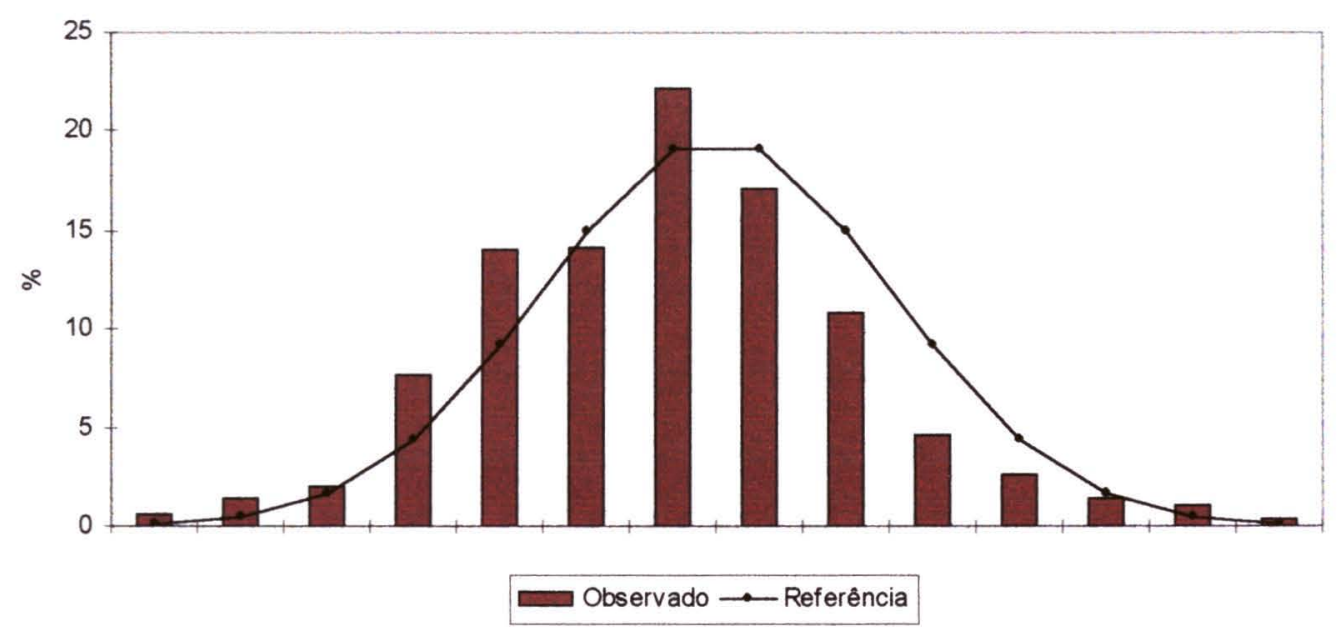

A Figura 50 apresenta a distribuição percentual do índice estatura/idade em comparação com a distribuição de referência, sendo observado a média de $-0,76$ e desvio padrão $1,02 \mathrm{em}$ z-escore, com afastamento médio significativo, inferior à distribuição de referência (NCHS 1977). 
Figura 50. Distribuição percentual do índice estatura/idade nas crianças indígenas menores de cinco anos e distribuição de referência NCHS/WHO.

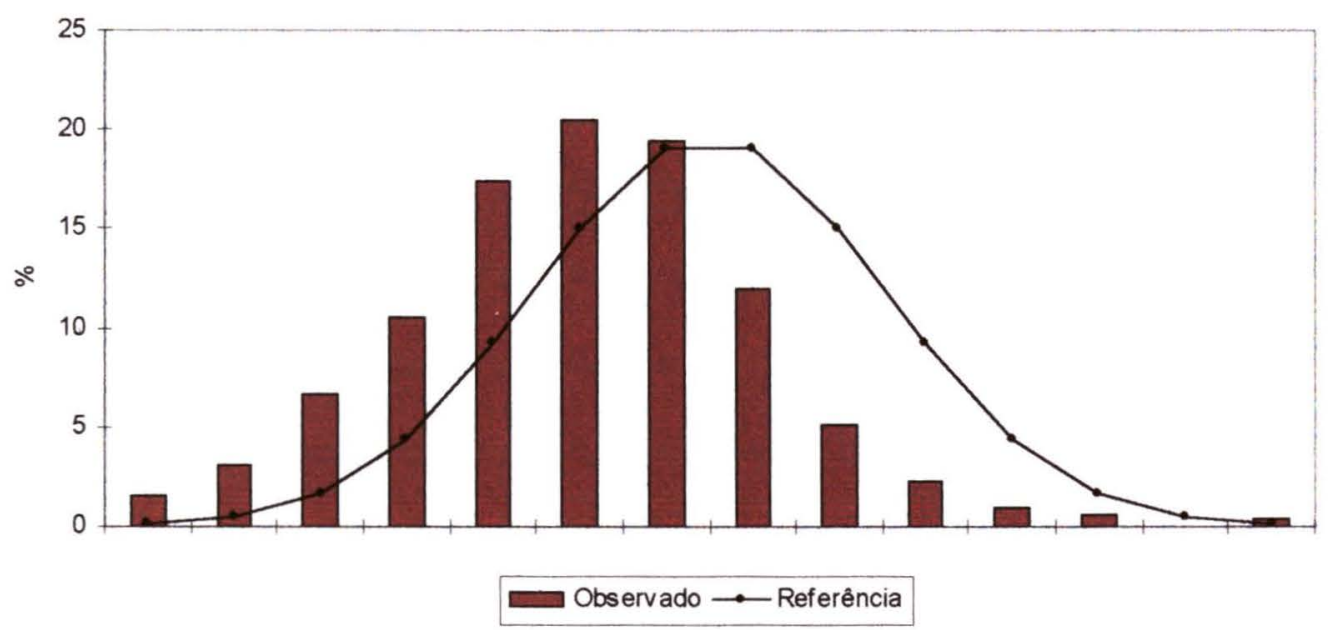

A Figura 51 ilustra a distribuição percentual do índice peso/estatura em comparação com a distribuição de referência, sendo observado a média de 0,30 e desvio padrão de 0,89 em z-escore, ligeiramente superior à referência (NCHS 1977).

Figura 51. Distribuição percentual do índice peso/estatura nas crianças indígenas menores de cinco anos e distribuição de referência NCHS/WHO.

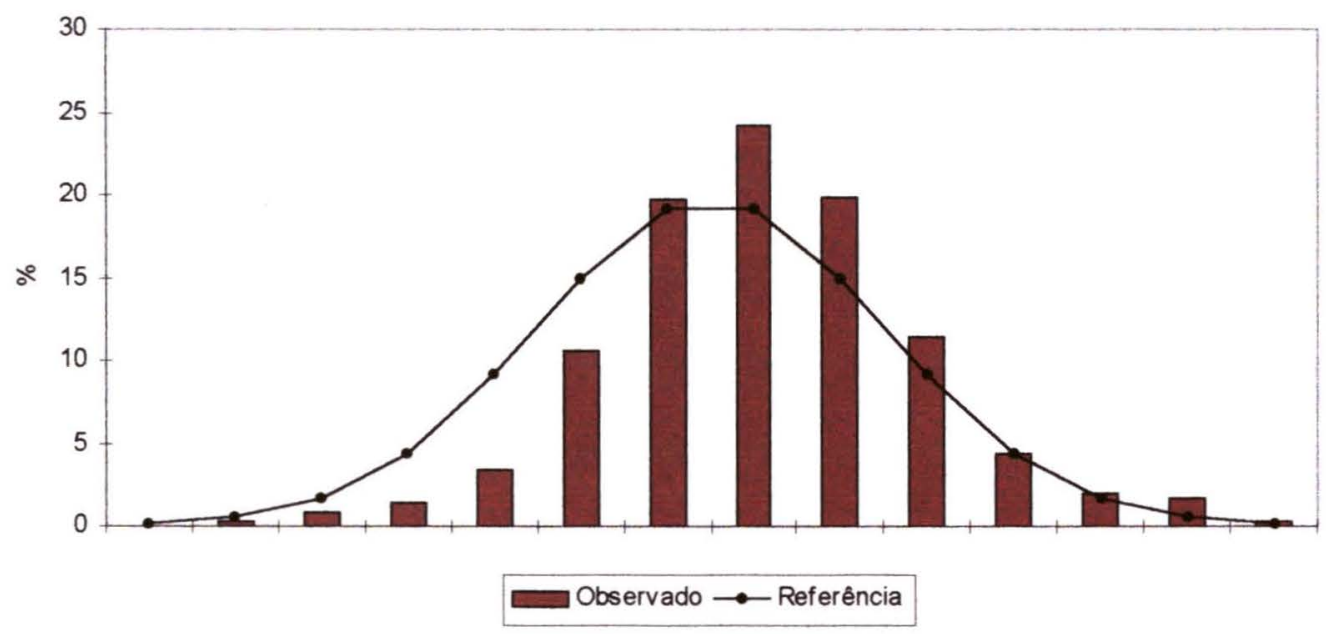


A Tabela 13 apresenta a média de z-escore e déficits nutricionais segundo o sexo, com maiores prevalências de déficits de peso/idade $(4,2 \%)$ e estatura/idade $(12,2 \%)$ para o sexo masculino.

Tabela 13. Distribuição da prevalência de déficits nutricionais segundo sexo das crianças indígenas. Comunidades Terena, MS, Brasil, 1999.

\begin{tabular}{lcccccc}
\hline & \multicolumn{2}{c}{ PESO/ESTATURA } & \multicolumn{2}{c}{ PESO/IDADE } & \multicolumn{2}{c}{ ESTATURA/IDADE } \\
\cline { 2 - 6 } SEXo & $\begin{array}{c}\text { média } \\
(z \text {-escore })\end{array}$ & $\begin{array}{c}\text { prevalência } \\
(<-2 \text { z-escores })\end{array}$ & $\begin{array}{c}\text { média } \\
(z \text { z-escore })\end{array}$ & $\begin{array}{c}\text { prevalência } \\
(<-2 \text { z-escores })\end{array}$ & $\begin{array}{c}\text { média } \\
(z \text {-escore })\end{array}$ & $\begin{array}{c}\text { prevalência } \\
(<-2 \text { z-escores })\end{array}$ \\
\hline Masculino & 0,26 & 0,0 & $-0,32$ & 4,2 & $-0,79$ & 12,2 \\
Feminino & 0,33 & 2,2 & $-0,23$ & 3,9 & $-0,74$ & 10,1 \\
$\begin{array}{l}\text { Ambos } \\
\text { os sexos }\end{array}$ & 0,30 & 1,1 & $-0,27$ & 4,0 & $-0,76$ & 11,1 \\
\hline
\end{tabular}

A prevalência de retardo de crescimento linear representados por déficit de estatura/idade, são apresentados na Tabela 14, onde são observadas maiores freqüências nas crianças de 12 a 18 meses de idade $(25,0 \%)$, com menor peso ao nascer $(25,0 \%)$ e de menor circunferência do braço $(52,4 \%)$. 
Tabela 14. Prevalência de déficits de estatura/idade e peso/estatura segundo características das crianças indígenas. Comunidades Terena. MS, Brasil, 1999.

\begin{tabular}{|c|c|c|c|}
\hline VARIÁVEIS & $\mathbf{N}$ & ESTATURA/IDADE & PESO/ESTATURA \\
\hline \multicolumn{4}{|l|}{ Idade (meses) } \\
\hline $0 \vdash 6$ & 44 & 4,5 & - \\
\hline $6 \vdash 12$ & 42 & 7,1 & 2,4 \\
\hline $12 \vdash 18$ & 36 & 25,0 & - \\
\hline $18 \vdash 24$ & 44 & 20,5 & 4,5 \\
\hline $24 \vdash 36$ & 66 & 13,9 & - \\
\hline $36 \vdash 48$ & 71 & 9,9 & 1,4 \\
\hline $48 \vdash 60$ & 51 & 7,8 & - \\
\hline \multicolumn{4}{|c|}{ Peso ao nascer (gramas) } \\
\hline$\leq 2500$ & 24 & 25,0 & - \\
\hline $2501-3000$ & 45 & 8,9 & - \\
\hline $3001-3500$ & 75 & 1,3 & 1,3 \\
\hline $3501-4000$ & 41 & 2,4 & - \\
\hline$>4000$ & 7 & - & - \\
\hline \multicolumn{4}{|c|}{ Circunferência braquial (desvio-padrão) } \\
\hline$<-2$ & 11 & 52,4 & 14,3 \\
\hline-1 & 15 & 26,8 & - \\
\hline Mediana & 11 & 6,9 & 0,6 \\
\hline+1 & - & - & -- \\
\hline+2 & - & - & - \\
\hline
\end{tabular}

Os dados da Tabela 15 apresentam a distribuição de déficits de estatura e peso/estatura no grupo estudado, segundo características socioeconômicas. Quando se examina a distribuição da desnutrição infantil por comunidades observa-se maior prevalência na Aldeia Córrego do Meio, quando comparada com as demais aldeias. A prevalência de déficits é inversamente proporcional à escolaridade dos pais e à faixa de renda familiar per capita, mais elevada em crianças residentes em domicílios com água proveniente de rios e poços rasos e escoadouro a céu aberto. 
Tabela 15. Prevalência de déficits de estatura/idade e peso/estatura segundo características socioeconômicas das famílias indígenas. Comunidades Terena, MS, Brasil, 1999.

\begin{tabular}{|c|c|c|}
\hline VARIÁVEIS & ESTATURA/IDADE & PESO/ESTATURA \\
\hline \multicolumn{3}{|l|}{ Aldeia } \\
\hline Córrego do Meio & 16,0 & 2,0 \\
\hline Água Azul & 14,0 & - \\
\hline Buriti & 9,3 & 0,8 \\
\hline Tereré & 3,3 & 1,6 \\
\hline \multicolumn{3}{|c|}{ Renda familiar per capita (salário mínimo) } \\
\hline $0 \vdash 0,5$ & 10,8 & 1,1 \\
\hline $0,5 \vdash 1,0$ & 8,7 & - \\
\hline$\geq 1,0$ & - & - \\
\hline \multicolumn{3}{|c|}{ Escolaridade da mãe (anos de estudo) } \\
\hline Sem escolaridade & 26,9 & 3,8 \\
\hline 1 a 4 & 10,0 & 0,7 \\
\hline 5 a 8 & 2,4 & - \\
\hline$>8$ & - & - \\
\hline \multicolumn{3}{|c|}{ Escolaridade do pai (anos de estudo) } \\
\hline Sem escolaridade & 33,3 & 11,1 \\
\hline 1 a 4 & 10,5 & 0,7 \\
\hline 5 a 8 & 9,4 & - \\
\hline$>8$ & - & - \\
\hline \multicolumn{3}{|c|}{ Abastecimento de água } \\
\hline Rede geral & - & - \\
\hline Rios/poços rasos & 25,0 & - \\
\hline Poço artesiano & 11,2 & 1,2 \\
\hline \multicolumn{3}{|c|}{ Escoadouro dos dejetos } \\
\hline Fossa séptica & 2,6 & - \\
\hline Vala negra & 9,9 & 2,6 \\
\hline Céu aberto & 27,3 & 4,5 \\
\hline
\end{tabular}

Com relação à circunferência braquial observou-se a prevalência de $\quad 6,9 \%$ de crianças com circunferência braquial $\leq-2$ desvios padrão, segundo padrão de referência NHANES I e II (WHO 1995).

As Figuras 52, 53 e 54 apresentam a comparação entre a referência NHANES I e II e médias das medidas de circunferência braquial, peso e estatura segundo grupos etários de crianças indígenas com e sem déficit de estatura/idade. 
Figura 52. Distribuição comparativa entre a referência NHANES e média da circunferência braquial por grupo etário, de crianças indígenas com e sem déficit de estatura/idade. Comunidades Terena, MS, Brasil, 1999.

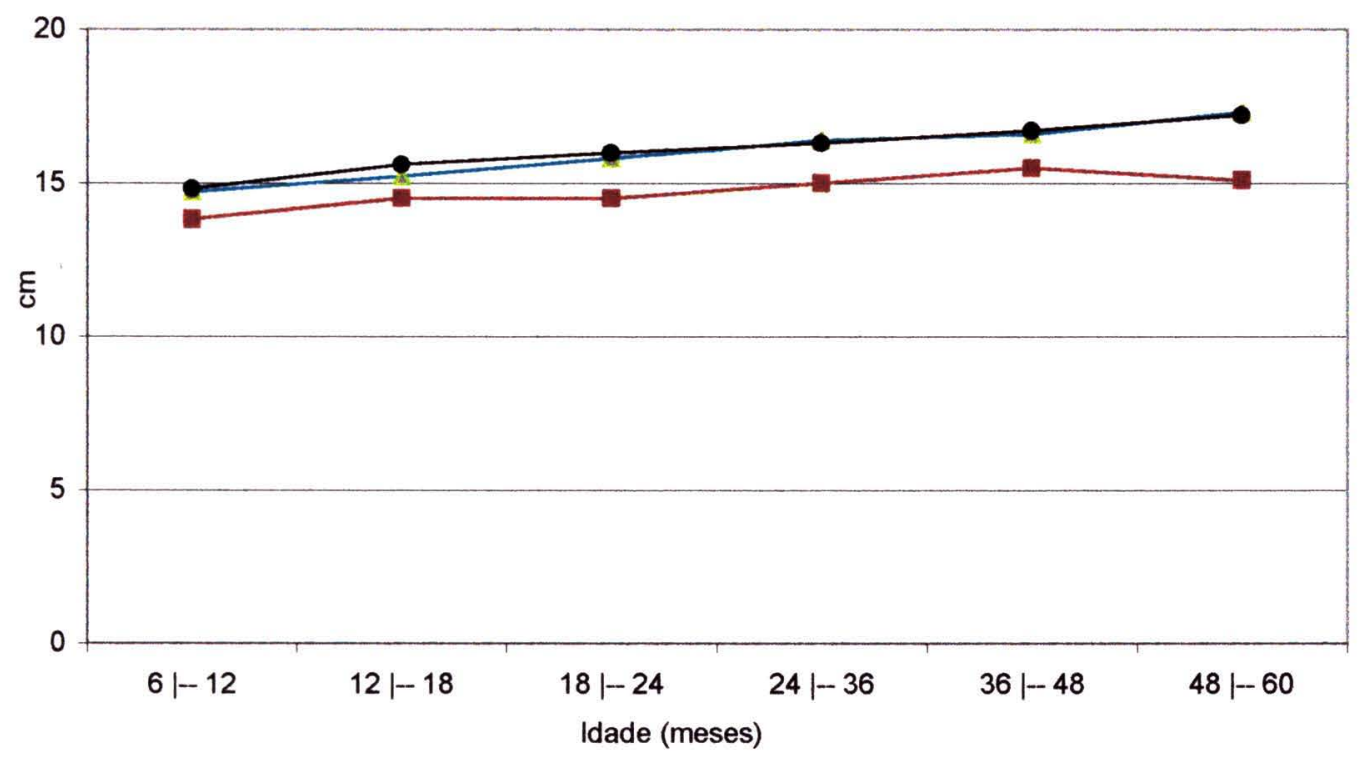

A comparação da média da circunferência braquial por grupo etário, mostrou que há desvantagem das crianças indígenas com déficit de estatura/idade, em todos os grupos de idade. Em relação às crianças indígenas que não apresentaram déficit de estatura/idade têm circunferência braquial semelhantes às crianças da referência. 
Figura 53. Distribuição comparativa entre a referência NCHS e média de peso por grupo etário, de crianças indígenas com e sem déficit de estatura/idade. Comunidades Terena, MS, Brasil, 1999.

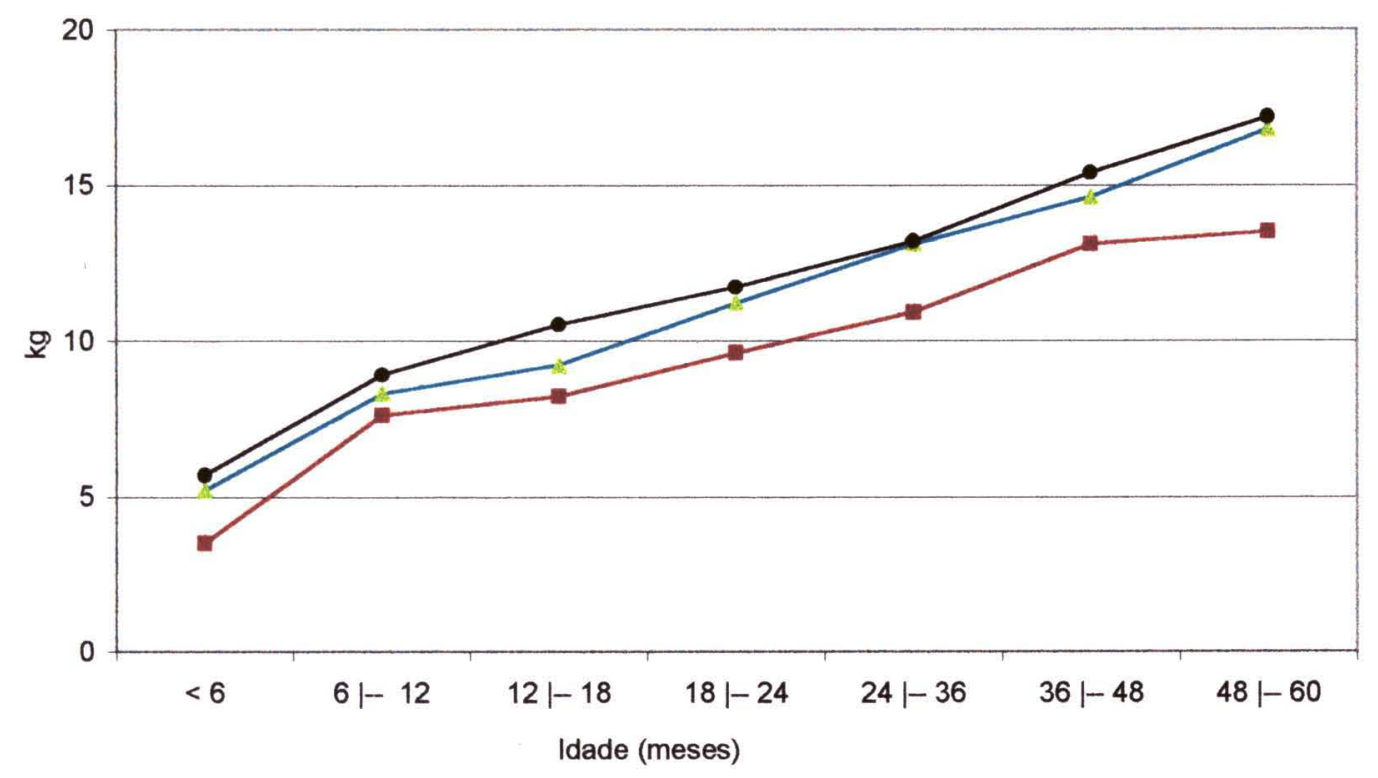

- Peso de crianças sem déficit de estatura/idade - Peso de crianças com déficit de estatura/idade - Referência

Com relação ao peso e estatura as crianças indígenas apresentaram médias inferiores às crianças da referência, especialmente as crianças com déficits de estatura/idade As crianças indígenas sem déficit de crescimento apresentam-se em situação intermediária. 
Figura 54. Distribuição comparativa entre a referência NCHS e média de estatura por grupo etário, de crianças indígenas com e sem déficit de estatura/idade. Comunidades Terena, MS, Brasil, 1999.

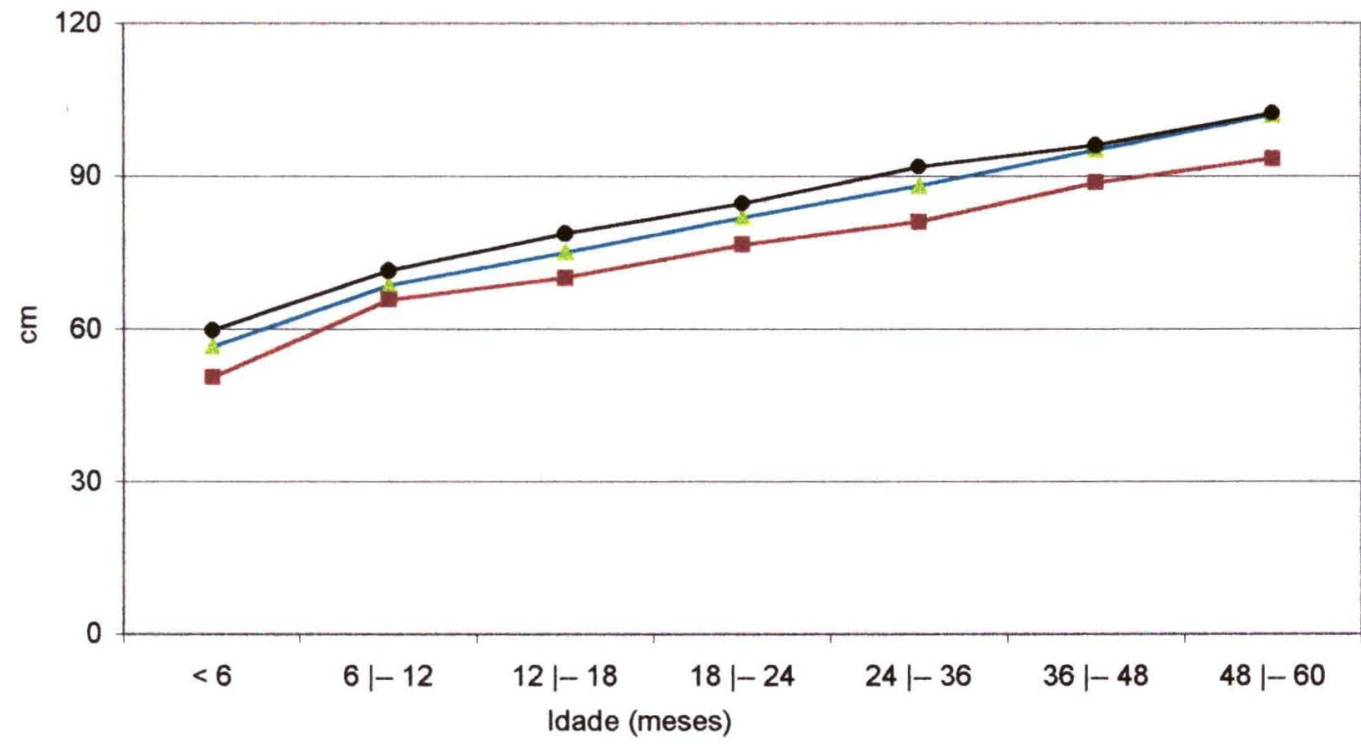

- Estatura de crianças sem déficit de estatura/idade - Estatura de crianças com déficit de estatura/idade 


\section{DISCUSSÃO}

A discussão dos achados deste estudo está organizada em duas etapas. Na primeira, é analisada a adequação dos critérios metodológicos adotados e, na segunda, as implicações dos principais problemas de saúde e nutrição identificados.

\subsection{Aspectos Metodológicos}

Apesar das contribuições dos resultados obtidos, pelo retorno das informações às comunidades estudadas, possibilitando a re-interpretação dos dados gerados, acredita-se que este estudo deve ser considerado como uma primeira aproximação na busca do conhecimento sobre as condições de saúde e nutrição do povo Terena. Isto porque, mesmo com o rigor utilizado na coleta e análise dos dados, este estudo apresenta limitações inerentes às características do trabalho.

A primeira restrição provém do fato desses resultados virem de um estudo transversal, o que sabidamente o faz menos apto para captar relações temporais entre as variáveis estudadas.

A segunda limitação diz respeito à mensuração do consumo de alimentos e na identificação dos determinantes da utilização dos serviços de saúde. Quanto ao consumo alimentar, as limitações ocorreram no estabelecimento das porções ingeridas pela criança, uma vez que, o prato servido pode alimentar mais de um indivíduo por vez, sendo o alimento partilhado pelos que estão ao redor, além do livre consumo de frutos enquanto brincam nos arredores, o que não permite aferir a quantidade absoluta de alimentos consumidos pelas crianças. $\mathrm{Na}$ utilização dos serviços, as dificuldades foram com relação à multiplicidade e complexidade dos fatores que influenciam a busca da cura, muitos deles relacionados à visão tradicional de saúde.

E uma terceira limitação se origina na dificuldade em compreender a riqueza e particularidades da cultura Terena, que transbordam de significados, dado o seu caráter dinâmico.

A escolha dos critérios adotados na avaliação do estado nutricional infantil seguiu recomendações convencionais da área (WHO 1995). Os entrevistadores e 
antropometristas foram preparados durante um longo período de treinamento, com a padronização das técnicas.

As medidas antropométricas foram obtidas pela coordenadora do estudo, auxiliada por acadêmicos com experiência anterior em inquéritos antropométricos. Os instrumentos de medida utilizados foram inicialmente testados para garantir precisão e, durante o estudo, periodicamente reavaliados.

O estudo piloto proporcionou convívio com famílias Terena, antes do início da coleta de dados nas aldeias. As entrevistas foram realizadas com as mães, pais e avós, todos envolvidos diretamente no cuidado infantil, respeitando-se a hierarquia familiar da autoridade paterna. A participação de guias indígenas foi de fundamental importância para a comunicação bilíngüe e esclarecimento da dinâmica das comunidades, assim como a instalação de unidades de apoio operacional, deram suporte necessário para a mobilização em campo.

Como método de controle de qualidade, a entrada de dados foi realizada em duplicata, por diferentes digitadores, permitindo a confrontação.

A representatividade dos dados levantados foi garantida pela número de participantes no estudo $(98,9 \%)$ e pela grande cooperação das famílias indígenas. As perdas ocorridas significaram $1,1 \%$ no total do estudo e $1,9 \%$ para medidas antropométricas.

\subsection{Desafios à Vida Terena}

\subsubsection{Condições Socioeconômicas e Ambientais}

As comunidades estudadas caracterizam-se por baixo nível socioeconômico, comprovado pela baixa renda familiar, baixa escolaridade dos pais e inadequadas condições ambientais de moradia.

MONTEIRO et al., (1992), verificaram que 43,1\% das crianças brasileiras menores de cinco anos, provenientes das famílias localizadas abaixo de 0,30 s.m. per capita, apresentavam um padrão de crescimento insatisfatório. Neste estudo, a renda não é um fator absoluto e outros elementos são considerados, dentre eles, o consumo alimentar, que determina a qualidade e quantidade dos alimentos consumidos, bem como o acesso da população a serviços essenciais, como os de saúde, educação e saneamento. Esse acesso, embora influenciado pelo nível da renda familiar, depende 
da atuação do setor público, ou seja, dos investimentos governamentais na área social, da eficiência das instituições públicas e da política de prestação de serviços (MONTEIRO et al., 1992).

No estabelecimento de uma "linha de pobreza", busca-se dimensionar o contingente da população que vive abaixo desse limite, não tendo acesso a bens e serviços para satisfazer suas necessidades básicas. No critério adotado pela Organização das Nações Unidas para Agricultura e Alimentação (FAO), a pobreza é caracterizada por renda per capita de até meio salário mínimo (GALEAZZI 1991). Se considerarmos como linha de pobreza um nível de satisfação de necessidades mínimas, com meio salário mínimo per capita, encontramos $87,7 \%$ da população estudada abaixo desta linha.

Quanto à escolaridade dos pais, foram observados baixos niveis de escolaridade em todas as comunidades, com menores índices para as mulheres, tendo efeito significativo sobre a prevalência de déficit nutricional infantil, comprovado em outros estudos como os de OLINTO et al., (1993) e LEI (1994).

A escolaridade do pai, segundo VICTORA et al., (1990), atua mais como um marcador de risco do que como um determinante, ou seja, grande parte de sua relação com o crescimento infantil é devida à sua associação com a renda familiar. Portanto, não se pode esperar que, simplesmente através de programas para aumentar a escolaridade, na ausência de mudanças estruturais mais profundas, seja possível melhorar os indicadores de desnutrição infantil em áreas consideradas carentes.

De acordo com os dados da PNAD (1999), Mato Grosso do Sul apresentava $9,2 \%$ de mulheres de 15 anos ou mais de idade, não alfabetizadas e nas comunidade indigenas estudadas foram observadas $12,3 \%$ (FIBGE 1999). Segundo NÓBREGA et al., (1991), quanto maior o nível educacional da mãe, menor a proporção de crianças desnutridas, em função do cuidado dispensado à criança, especialmente com relação à higiene e alimentação.

A falta de educação ou as diferenças na sua qualidade não só mantém as condições que fazem com que a desigualdade social subsista, mas também reproduz e cria diferenças que, com o tempo, perpetuam a pobreza e a exclusão.

É importante ressaltar que a educação escolar presente nas aldeias indígenas não é diferenciada, nem gerenciada pelas comunidades. São extensões de escolas rurais, sendo um instrumento de imposição de valores e normas da sociedade envolvente (MANGOLIM 1999). 
O número médio de filhos nascidos vivos nas famílias estudadas foi de 3,8, valor superior ao observado no Estado de Mato Grosso do Sul, onde na região urbana a média de filhos é 2,5 e na região rural 3,1 filhos (FIBGE 1999).

Segundo a Pesquisa Nacional por Amostra de Domicílios (PNAD), o número de domicílios com água, com canalização interna, no Brasil era de $85,6 \%$, com $51,9 \%$ para a área rural; para Mato Grosso do Sul $89,8 \%$, sendo $75,3 \%$ para a área rural (FIBGE 1999). Nas comunidades indígenas estudadas, foram identificados $17,1 \%$, sendo $3,0 \%$ para as aldeias localizadas na área indígena Buriti.

Quanto a domicílios que dispunham do sistema de esgotamento sanitário, no Brasil foram identificados $91,5 \%$, com $67,1 \%$ para a área rural; em Mato Grosso do Sul foram identificados $96,8 \%$, sendo $91,3 \%$ na área rural (FIBGE 1999). Nas comunidades indígenas estudadas, $89,6 \%$, sendo $88,5 \%$ para as aldeias da área indígena Buriti (aldeias rurais), destes, $86,5 \%$ dos domicílios tinham os dejetos esgotados para uma fossa negra.

Domicílios com instalações deficientes ou inexistentes, provocam transmissão de doenças infecciosas e parasitárias, conseqüentemente agravando as condições de saúde (SIMÕES 1992).

Estudo realizado entre crianças Guarani, de 0 a 65 meses de idade, identificou a prevalência de parasitose intestinal em $65,6 \%$, destas, $62,7 \%$ apresentaram infecção parasitária múltipla (SERAFIM 1997).

Em relação ao lixo, no Brasil $79,9 \%$ tinham o lixo coletado direta ou indiretamente, com 19,6\% para a área rural; Mato Grosso do Sul 80,6\%, com 6,2\% para a área rural (FIBGE 1999). Das comunidades indígenas estudadas, apenas a Aldeia Tereré contava com este serviço $(18,4 \%)$.

Quanto à existência de iluminação elétrica nos domicílios, no Brasil 94,8\%, com 75,4\% para a área rural; em Mato Grosso do Sul, $95,9 \%$, sendo $80,4 \%$ para a área rural (FIBGE 1999). Nas comunidades indígenas estudadas, $65,6 \%$, sendo $59,8 \%$ nas aldeias Buriti, Córrego do Meio e Água Azul.

Verificou-se associação entre as condições de saneamento, representadas pela disponibilidade de água e esgoto sanitário no domicílio, com a prevalência de retardo de crescimento. Além deste efeito, as más condições de saneamento podem estar influenciando os padrões de morbidade, especialmente a freqüência de diarréia, referendados em outros trabalhos, como o de BLACK (1984) e VICTORA (1992). 
Nas condições ambientais, aparentemente homogêneas na pobreza, foram observadas diferenças significativas na distribuição das variáveis socioeconômicas, com relação à localização dos domicílios, isto é, a aldeia a que pertenciam.

A Aldeia Tereré apresentou melhores condições de saneamento, renda e assistência à saúde, justificada pela localização no perímetro urbano do município de Sidrolândia, onde foram observadas melhores condições nutricionais, melhor assistência à saúde e menor morbidade entre as crianças. Por outro lado, apresentou espaço territorial irrisório, ausência de plantações, aglomeração dos domicílios, maior número de mães adolescentes e de famílias sem a presença paterna.

Com relação à existência de equipamentos nos domicílios da área rural, no Brasil o rádio esteve presente em $83,7 \%$ dos domicílios rurais; em Mato Grosso do Sul, $81,8 \%$ (FIBGE 1999) e nas aldeias estudadas, $45,6 \%$. Quanto à existência de televisão, no Brasil, 63,8\%; em Mato Grosso do Sul, $68,4 \%$ e nas aldeias, $34,5 \%$. Nas comunidades indigenas o rádio e a televisão são meios de comunicação de grande importância, devido ao isolamento geográfico e à inexistência de outros canais de informações.

Com relação à geladeira, no Brasil, 52,5\%; em Mato Grosso do Sul, 67,6\% e nas aldeias, 21,6\%. Quanto à existência de freezer, no Brasil, 14,5\%; em Mato Grosso do Sul, 27,6\% e nas aldeias 2,3\%. (FIBGE 1999). Alimentos guardados em temperatura ambiente podem ser contaminados, devido à multiplicação bacteriana, podendo provocar infeç̧ões intestinais. A disponibilidade de geladeira contribui para impedir essa contaminação.

Esses resultados traduzem diferenças significativas na posse de bens, provavelmente expressando a baixa renda familiar disponível para aquisição de utilidades domésticas. Com relação à disponibilidade desses equipamentos, segundo a localização, foram encontrados em maior freqüência na Aldeia Tereré.

A implementação de medidas e melhorias nas condições de vida nessas comunidades depende fortemente da atuação do setor público, ou seja, através de políticas efetivas e investimentos específicos para populações indígenas, amenizando os efeitos danosos da desigualdade social. Apesar da importância evidente da gravidade das condições de vida e da necessidade de assistência à saúde das populações indígenas, não se tem dado a devida atenção a esse problema. 
Lutar por melhores condições de saúde e nutrição de povos indígenas é acreditar em mudanças possíveis buscando um modelo de assistência capaz de assegurar a dignidade e a vida desses povos.

\subsubsection{Assistência à Saúde}

Os dados indicaram baixo nível de utilização de serviços de assistência à saúde materno-infantil. Entre os fatores que poderiam estar restringindo as possibilidades de utilização, destacam-se os poucos recursos da família e as características dos serviços de saúde em nível local.

Com relação aos recursos da família, verificou-se a impossibilidade econômica de utilizar sistemas privados e as dificuldades de acesso aos serviços públicos dos municípios vizinhos. As famílias não dispunham de recursos mínimos para cobrir esses gastos, afetando suas possibilidades de utilização.

A predisposição dos indivíduos a utilizarem os serviços públicos externos é prejudicada pela distância geográfica, os custos de locomoção e alimentação, pagamento de taxas e as barreiras culturais a serem vencidas no convívio fora das aldeias. Nos serviços externos as relações são marcadas pelo preconceito, resultando muitas vezes na oferta de assistência qualitativamente inferior ao oferecido à população em geral. LANGDON (1988) ressalta a freqüência com que profissionais de saúde expressam preconceitos, estigmatizando o índio naquelas regiões onde é intenso o contato interétnico.

A distância e a dificuldade para a remoção dos pacientes caracterizavam o impedimento geográfico e econômico aos serviços de assistência à saúde. A exceção ocorria na Aldeia Tereré, localizada no perímetro urbano, próxima de uma unidade de assistência. Se formos comparar com outras etnias do Mato Grosso do Sul, os Terena estão geograficamente próximos de locais de assistência, mesmo assim, o nível de utilização dos serviços é insuficiente.

Com relação às características dos serviços de saúde em nível local, verificou-se a precária organização dos serviços, tanto no que diz respeito às instalações físicas quanto aos recursos materiais e humanos para implementação das ações. A formação de recursos humanos para atuar nas comunidades indígenas era inexistente, agravada pela carência de disciplinas relativas às ciências sociais e antropologia da saúde nos currículos dos profissionais atuantes. 
Quanto ao gerenciamento do sistema, não existiam registros adequados sobre o estado de saúde dos indivíduos. Não foram identificadas ações educativas no período estudado, nem mesmo informações aos pais sobre os principais problemas de saúde das crianças.

No caso de pacientes que utilizavam serviços públicos externos à aldeia, não existia continuidade de tratamento entre os serviços, não ocorrendo mecanismos formais de referência e contra-referência. Não foram verificadas ações que levassem em conta os problemas de saúde em suas perspectivas histórica, cultural e social.

De acordo com COIMBRA JUNIOR e SANTOS (2000), existe uma danosa invisibilidade demográfica e epidemiológica de populações indígenas nos bancos de dados oficiais.

Embora uma grande utilização dos serviços de saúde não seja um objetivo em si mesmo, presume-se que deve haver um nível mínimo de uso e suficiente eqüidade no acesso aos serviços, para garantir a saúde de uma população. A eqüidade na utilização dos serviços é defendida como elemento fundamental no processo de redução dos diferenciais em saúde entre grupos populacionais. Os resultados observados sugerem que os que recebem os benefícios são principalmente aqueles que possuem a maior facilidade de acesso e não os que correm maiores riscos.

Melhoras no serviço público destinado às populações indígenas minimizariam as conseqüências das más condições de saúde e nutrição, na ausência de mudanças mais profundas, capazes de permitir a garantia da terra, aumento na escolaridade e renda mensal familiar, compatível com uma qualidade adequada de vida nessas comunidades.

Se analisarmos a responsabilidade do governo para com a saúde das populações indígenas, entende-se que o Estado é diretamente responsável quanto à prestação de assistência e que não pode estar ausente, mas deve proteger este direito, tomando as medidas apropriadas no sentido de cumpri-lo (GRUSKIN 1997).

Segundo CONFALONIERI (1993), a carência de recursos e a instabilidade político-administrativa das instituições públicas responsáveis pela assistência aos povos indígenas geram descontinuidade das ações em saúde.

$\mathrm{O}$ novo modelo de assistência às populações indígenas requer revisão crítica das experiências anteriores, em sintonia com a atual condição de saúde dos diferentes grupos, ampliando com análise epidemiológica e social, não ignorando os valores e saberes locais e envolvendo diversos atores sociais. 
O atual modelo de atenção à saúde indígena para Mato Grosso do Sul está organizada na forma de um (1) distrito sanitário para cobrir a totalidade das comunidades indígenas (54 aldeias). É importante analisar se um distrito sanitário é suficiente para atender a diversidade cultural, epidemiológica e geopolítica dos diversos grupos.

Faz-se necessária avaliação das estratégias seguidas, rumo à efetiva participação e controle social dos povos indígenas na consolidação do sistema. Trata-se, sobretudo, de compreender os problemas e de encontrar soluções para resolvê-los, integrando a visão dos que estão diretamente implicados no sistema.

$O$ reconhecimento e valorização das diferentes práticas e sistemas indígenas de saúde, com a participação comunitária nos diversos níveis de ação são consideradas fundamentais na concepção de um sistema de saúde diferenciado.

De acordo com LANGDON (1998), os profissionais de saúde que prestam assistência às comunidades indígenas devem conhecer a natureza dos sistemas indígenas de saúde e como as práticas fazem parte da sua cultura como um sistema simbólico, composto de valores, representações e significados inter-relacionados, estando preparados e capacitados para atuar junto às populações culturalmente diferenciadas. Nesse sentido, deveriam ser executados programas permanentes de formação e especialização de recursos humanos para atuação junto às comunidades indígenas.

De acordo com BUCHILLET (2000), "as percepções etno-médicas não são os únicos fatores em jogo na conduta terapêutica dos pacientes e na adesão ao tratamento", mas a "consideração das representações e práticas em matéria de saúde e de doença é, no entanto, imprescindível, pois elas permitem prever as dificuldades potenciais de aceitação das condutas preventivas e terapêuticas preconizadas pela medicina ocidental, além de ajudar a delinear e implementar estratégias de intervenção e educação sanitária inovadoras e fundamentadas no contexto sóciocultural local" (p.7).

A baixa cobertura de assistência pré-natal observada $(61,6 \%)$, reduzido número de mulheres que realizaram mais de 6 consultas $(26,6 \%)$ e iniciaram o acompanhamento no primeiro trimestre de gravidez $(47,7 \%)$, representaram situação de risco para gestantes indígenas e seus filhos, uma vez que, as mulheres que não tiveram assistência, eram as de piores condições socioeconômicas. 
A assistência pré-natal foi crescente em função do nível de escolaridade materna, da renda familiar e da proximidade do domicílio ao local de assistência. Deve-se ressaltar que $o$ atendimento pré-natal satisfatório deve iniciar-se nos primeiros meses de gestação e serem realizadas, no mínimo, seis consultas durante a gestação (MINISTÉRIO DA SAÚDE 1988).

Estudo realizado em Campo Grande (MS), indicou que quase a totalidade das mulheres $(95,9 \%)$ realizaram acompanhamento durante a gestação, o que demonstra a desigualdade dos cuidados oferecidos às gestantes nas diferentes regiões do Estado (RIBAS et al., 1998).

Os resultados da PNDS (1996) mostram que, no país, 85,7\% das mulheres realizaram consultas de pré-natal, 50\% dessas mulheres tiveram mais de 7 consultas. Observa-se ainda que, entre as mulheres que relataram pelo menos uma consulta prénatal, $66,0 \%$ recebeu atendimento durante o primeiro trimestre de gravidez (BENFAM 1996).

No Estado do Maranhão (1996), 71,3\% das mulheres tiveram atendimento prénatal, com $43,9 \%$ realizando 5 ou mais consultas, sendo $69,8 \%$ iniciado no primeiro trimestre de gravidez (COIMBRA e MOCHEL 1997).

Por essas razões é de vital importância a promoção de intervenções multisetoriais, dirigidas à melhoria das condições de vida e saúde das mulheres indígenas, tanto como um direito próprio, quanto para a garantia do nascimento seguro e a sobrevivência de seus filhos.

Com relação à cobertura do parto, em instituição de saúde, nas comunidades estudadas foram observados $73,6 \%$ de partos hospitalares. A exceção ocorreu na Aldeia Tereré, onde, 98,4\% dos partos tiveram assistência hospitalar, mas o que poderia significar um valor às condições de saúde das mulheres que lá residiam, pode ter-se convertido em prejuizo, uma vez que, $34,4 \%$ desses partos, foram operatórios. De acordo com o Ministério da Saúde (1996), a cobertura em nível nacional, de partos em instituições de saúde, era de 91,5\% (MARANHÃO et al., 1999).

Com relação ao parto operatório, FAUNDES e CECCATI (1991) estimam que custa o dobro do parto normal, envolvendo riscos adicionais de prematuridade, mortalidade materna e redução do aleitamento, devido à intensa dor abdominal. Estes autores sugerem que o primeiro motivo tácito para o parto operatório continua sendo a esterilização cirúrgica. 
Os dados disponíveis sugerem uma tendência crescente na prevalência do parto operatório no Brasil. Em 1986, a freqüência era de 31,0\%, alcançando 36,0\% em 1996. Na Região Centro-Oeste 41,0\%; em Mato Grosso do Sul, 55,7\% e neste estudo, $17,2 \%$. O padrão epidemiológico reconhecido como aceitável é que $90,0 \%$ dos partos deveriam ser vaginais (MARANHÃO et al., 1999).

A hipótese de estabilização da taxa de parto operatório tem sido apontada no Estado de São Paulo, tendo permanecido em torno de $48 \%$ entre 1987 a 1993 (RATTNER 1996).

O peso ao nascer tem relação direta com a qualidade de vida, crescimento, desenvolvimento e mortalidade infantil (VICTORA et al., 1987).

Estudo prospectivo realizado no Rio Grande do Sul indicou que crianças nascidas de baixo peso estavam expostas a um risco onze vezes maior de morrer no primeiro ano de vida e cinco vezes maior de virem a apresentar déficit ponderal no segundo ano de vida (VICTORA et al., 1987). Em comparação com os dados da PNSN (1989), onde a incidência nacional era de $10,0 \%$, a regional $8,6 \%$ e a rural $12,3 \%$, os dados sobre baixo peso ao nascer, obtidos nesse estudo $(12,5 \%)$ são superiores, aproximando-se do nível alto, segundo a classificação internacional (MONTEIRO 1992; UNICEF 1991). Cabe ressaltar que pode ter ocorrido subestimação na análise, considerando que não foram obtidas informações de $45,8 \%$ das crianças, representadas por aquelas nascidas nos domicílios.

De acordo com os dados da PNDS (1996), a incidência de recém-nascidos de baixo peso estaria em torno de $9,2 \%$, sendo $11,1 \%$ nas áreas rurais e $8,6 \%$ nas áreas urbanas (BEMFAM 1996).

Estudo realizado em Campo Grande (MS), identificou a incidência de baixo peso ao nascer em torno de $8,7 \%$ (RIBAS 1997).

De acordo com PASTOR et al., (1973), uma prevalência de baixo peso ao nascer menor que 7\% indica bom estado de nutrição da população, uma vez que esta era a prevalência verificada na maioria dos países desenvolvidos.

Esses resultados podem estar refletindo a qualidade de vida do grupo maternoinfantil, uma vez que o peso ao nascer pode ser determinado por fatores biológicos, socioeconômicos e ambientais, aos quais a mulher está exposta durante a gestação (ALMEIDA 1994). Considerando o sexo feminino, retardo de crescimento na infância pode determinar mulheres adultas de baixa estatura, sujeitas a um maior risco de gerar crianças com baixo peso ao nascer (KRAMER 1987). 
Segundo TONETE e NÓBREGA (1981), o baixo peso ao nascer condiciona o crescimento pós-natal, que fica abaixo do esperado, tendo-se por referência, crianças nascidas com peso adequado para a idade gestacional.

Para MONTEIRO (1992), uma das causas que provavelmente concorrem para aumentar a incidência de baixo peso ao nascer é a deficiência no atendimento prénatal, pois exatamente os grupos populacionais identificados como sujeitos a um maior risco de nascimentos de baixo peso são os que apresentam maior proporção de gestantes que não recebem adequada atenção pré-natal.

A incidência de baixo peso ao nascer observada, assim como a importância de ações preventivas, evidenciam a necessidade imediata de atenção às mães indígenas durante a gravidez, por meio de um programa que considere os valores culturais e as peculiaridades que envolvem concepção, gestação e nascimento em uma comunidade indígena.

Com relação à vigilância do crescimento e desenvolvimento infantil, os valores encontrados são baixos $(14,7 \%)$ e se referem apenas ao crescimento, com nenhum aspecto relativo ao desenvolvimento sendo avaliado.

Existem desigualdades no acesso às ações de acompanhamento de crescimento, uma vez que, a cobertura segundo a localização do domicílio indica melhores percentuais na Aldeia Tereré e precariedade da ação nas demais comunidades.

A posse do cartão com a curva de crescimento justifica-se apenas quando existem pesagens regulares registradas no mesmo. A pesagem periódica intensifica o contato com a família, favorece o aumento da cobertura das ações de atenção básica à saúde, permite a identificação de desvios e o tratamento precoce ao crescimento inadequado (UNICEF 1995).

A cobertura vacinal média $(75,7 \%)$ esteve próxima aos valores nacionais que indicam $75,0 \%$ para todas as vacinas, independente da idade (DANIEL-RIBEIRO 1995).

As doenças, de modo geral, prejudicam o crescimento normal de uma criança, mas em países em desenvolvimento, o retardo de crescimento nos primeiros anos de vida são causados por dois fatores preveníveis: alimentação insuficiente e infecções. As infecções, em geral, atuam sobre o tamanho do corpo e o crescimento, com efeito direto sobre o metabolismo e a nutrição (WATERLOW 1974; OMS 1983).

As freqüências de diarréia aguda observadas neste estudo, no dia da entrevista $(9,9 \%)$ e no período de quinze dias $(26,6 \%)$, foram consideradas alarmantes quando 
comparadas com a freqüência global de diarréia nos quinze dias anteriores à entrevista, detectada pela PNSN (1989), para as crianças brasileiras menores de cinco anos, que foi de 10,0\%, sendo 8,9\% para a região Centro-Oeste (FIBGE 1992).

Dados da PNDS (1996) apresentam a freqüência de 3,2\% para a diarréia no dia da entrevista e 13,1\% para a diarréia nas duas últimas semanas (BENFAM 1996).

A diarréia foi responsável por $44,1 \%$ das internações hospitalares e as infecções respiratórias por $41,1 \%$, sugerindo a falta de atendimento precoce $\mathrm{e}$ reforçando a necessidade da assistência adequada em nível local.

Estudo realizado em 1987/88, em Belém, Brasília, Fortaleza, Rio de Janeiro e São Paulo, apresentou respectivamente a freqüência de 13\%, 8,6\%, 11,2 e 7,7\%. A pior situação, encontrada em Belém foi explicada, devido à elevada freqüência de aleitamento materno misto nos seis primeiros meses de vida e à precária condição de abastecimento de água, possibilitando maior exposição a agentes infecciosos (MINISTÉRIO DA SAÚDE 1990).

Em estudo realizado no Maranhão (1996), foi verificada a prevalência de 8,1\% de diarréia aguda, no dia da entrevista e 16,1\% nas duas semanas anteriores ao inquérito (RIBEIRO e ARAGÃO 1997).

Dados sobre a ocorrência de diarréia foram colhidos em nove Estados da região nordeste (1991), sendo observado $6,5 \%$ de diarréia no dia da entrevista e $16 \%$ nas duas semanas anteriores (UNICEF 1995).

De acordo com NABARRO et al., (1988), episódios freqüentes de infecções, principalmente a diarréia e doenças respiratórias, influenciam o crescimento infantil, levando à perda aguda de peso e prejudicando o crescimento linear.

Estudos realizados em Gâmbia, África, revelaram que a principal causa do atraso ponderal, encontrado entre crianças de seis a trinta e seis meses de idade, foi a diarréia (CONDON-PALONI 1977; ROWLANDO 1988).

Segundo TOMKINS e WATSON (1989), as crianças com retardo de crescimento têm infecções por um período mais prolongado e alto índice de mortalidade associado a infecções, sendo que, as comunidades mais atingidas pelas deficiências nutricionais são, via de regra, aquelas com maior prevalência de infecções.

O acesso ao xamã é facilitado pela proximidade, pela ligação afetiva e pela confiança, sendo líder espiritual da comunidade, desde sua implantação. Sua terapêutica é considerada sempre benéfica, não existindo incompatibilidade entre o 
tratamento xamânico e o prescrito pela medicina ocidental, uma vez que o primeiro atua no nível das causas e não nos efeitos (BUCHILLET 2000). A procura do tratamento xamânico é guiada pela necessidade de descobrir a "causa última" da doença, isto é, "aquela que vai relacionar a doença particular do paciente ao seu meio físico e social" e explicar seu significado (BUCHILLET 2000, p.4). Não é contraditório em si e nem traduz incoerência das representações, uma vez que, tais alternativas terapêuticas heterogêneas agem sobre esferas de ação distintas (LANGDON e MacLENNAN 1979; BUCHILLET 1991; LANGDON 1998).

Verifica-se a necessidade do reconhecimento e valorização de um outro sistema de interpretação de doenças, ajustando a medicina ocidental aos recursos terapêuticos já existentes nas comunidades indígenas (BUCHILLET 1991; LANGDON 1998).

De acordo com CONFALONIERI (1989, p.445), a saúde de populações indígenas é a "expressão direta das formas tradicionais de ocupação do espaço territorial que assegure a reprodução biológica e cultural dos grupos; da integridade de seus sistemas de crenças e valores responsáveis pela coesão social, bem como das relações de contato com a sociedade envolvente e, portanto, da política indigenista desenvolvida no país".

\subsubsection{Nutrição}

Os resultados indicam monotonia e inadequação da dieta infantil, pela insuficiente disponibilidade de alimentos nos domicílios.

A garantia da alimentação para as famílias indígenas depende basicamente do acesso à terra e de recursos agrícolas, de modo a garantir suficiente produção doméstica, melhorando os aspectos quantitativos e qualitativos da dieta infantil. A produção agrícola desenvolvida nas comunidades varia de uma estação para outra e com condições ambientais nem sempre favoráveis, como o observado no período do estudo, em que a região apresentou longo período de estiagem, com ausência de chuvas, retardando sensivelmente o plantio, o que resultou em roças pequenas e pouco produtivas, contrariando a maior aspiração do povo Terena. As poucas famílias que comercializam o produto de suas colheitas enfrentavam dificuldades em conseguir preços adequados e competitivos no mercado, em função de inúmeros fatores fora de seu controle. Essas famílias dificilmente conseguiam manter estoques 
de alimentos em quantidades suficientes e tinham poucas oportunidades de desenvolver alternativas que as protegiam em épocas de escassez.

O consumo médio de proteína esteve abaixo das recomendações (RDA) para as crianças menores de 12 meses e superior à recomendação, na dieta das crianças maiores de 12 meses de idade.

Com relação à distribuição percentual dos macronutrientes na disponibilidade total de energia, os carboidratos representavam aproximadamente $40 \%$ das calorias consumidas de 0 a 5 meses; $54 \%$ de 6 a 12 meses; $61 \%$ de 12 a 35 meses e $64 \%$ de 36 a 59 meses.

O consumo de energia proveniente das gorduras, estive ao redor de $51 \%$ na dietas das crianças de 0 a 5 meses, representado basicamente pelo aleitamento materno; 37\% de 6 a 11 meses, representada pela introdução de alimentos complementares; $26 \%$ de 12 a 35 meses e $21 \%$ de 36 a 59 meses. A partir dos 6 meses de idade, os percentuais observados não atingem as atuais recomendações nutricionais de consumo de gordura na infância, uma vez que é proposta para os primeiros dois anos de vida, uma dieta com aproximadamente $50 \%$ do valor calórico total, para assegurar o consumo adequado de energia necessária ao crescimento infantil.

Estudos realizados em países em desenvolvimento têm demonstrado que crianças pertencentes a famílias de baixo poder aquisitivo consomem dietas com menor valor energético, quando comparadas a crianças de países desenvolvidos (UNICEF 1998).

Os níveis de consumo de vitamina A foram baixos, sendo especialmente reduzidos a partir dos 12 meses de idade. A adequação média foi de $62,5 \%$ para a vitamina $\mathrm{A}$, independente da idade. As principais fontes de vitamina $\mathrm{A}$, além do leite, são a gema de ovo, figado, manteiga e vegetais verdes e amarelos (SILVA e MONNERAT 1986). Neste estudo, entre as crianças maiores de 1 ano de idade, o consumo de produtos lácteos e verduras era particularmente reduzido. Não foram observadas atividades educativas de valorização e recomendações para o consumo de alimentos regionais, como a bocaiúva, araçá, buriti, pequi, araticum e outros.

A deficiência de vitamina A pode acarretar alterações oculares, retardo no crescimento, aumento da suscetibilidade às infecções, aumento do risco de doenças respiratórias e diarréias (SOMMER 1995). 
O consumo de alimentos fontes de ferro foi reduzido, sendo insuficiente em todos os grupos etários, com adequação média de $31,2 \%$. A anemia por deficiência de ferro é, provavelmente, o problema nutricional mais comum em todo o mundo. Atinge mais de $50 \%$ da mulheres nos países em desenvolvimento e elevada porcentagem das crianças menores de cinco anos (UNICEF 1998).

Estudo realizado entre crianças Guarani, de 0 a 65 meses de idade, identificou a prevalência de $68,5 \%$ de anemia, com maiores índices na faixa etária de 6 a 24 meses (SERAFIM 1997).

A deficiência de ferro parece afetar lactentes e pré-escolares em todo o país, até mesmo os estratos da população de melhor nível socioeconômico (MONTEIRO e SZARFARC 1987).

A anemia em gestantes aumenta o risco de morte, devido à maior probabilidade de hemorragia no momento do parto e o recém-nascido enfrenta alto risco de ter o crescimento e desenvolvimento comprometidos (GILLESPIE et al., 1991).

O consumo de cálcio foi superior às recomendações nos primeiros meses de vida $(178,5 \%)$, mas insuficiente a partir dos 6 meses $(49,8 \%)$.

Fontes essenciais de cálcio são o leite e seus derivados, o que explicaria a inadequação da dieta neste mineral, devido ao baixo consumo de produtos lácteos. A deficiência de cálcio na infância afeta acima de tudo os ossos, que nesta fase estão em desenvolvimento (CARRAZA e MARCONDES 1991).

Com relação à vitamina $C$, foram observados níveis de consumo próximos das recomendações, com adequação média de $88,9 \%$. As famílias tinham acesso a frutos regionais que continham vitamina $C$, mas a quantidade e o periodo de produção desses frutos era limitada, necessitando da implementação de projetos de cultivo.

A vitamina $C$ é essencial ao metabolismo orgânico e ao funcionamento celular, pois participa de diversos processos metabólicos, dentre eles a formação do colágeno e síntese de epinefrina, corticoesteróides e ácidos biliares. Além de co-fator enzimático, participa dos processos de óxido-redução, aumentando a absorção de ferro não-heme e a inativação de radicais livres (COZZOLINO 1997).

A prevalência e a duração do aleitamento materno foram elevadas em todas as aldeias, sendo observado maior índice na Aldeia Água Azul, com a totalidade das crianças sendo amamentadas aos doze meses. 
$\mathrm{Na}$ análise comparativa com outros estudos, para o grupo de crianças com seis meses de idade, observa-se que a prevalência de aleitamento natural nas comunidades indígenas é nitidamente superior às prevalências observadas em outras comunidades.

Em 1977, inquérito realizado em Paulínea, São Paulo, em crianças menores de dois anos de idade, mostrou que a idade média do desmame era de 3,3 meses, com $34 \%$ das crianças sendo amamentadas aos seis meses (HARDY et al., 1982).

VICTORA et al. (1988) estudaram crianças nascidas em Pelotas, Rio Grande do Sul, sendo observada a duração mediana de 3,28 meses. Aos seis meses de idade, $30 \%$ dessas crianças eram amamentadas. Já em 1993/94, foi observada a duração mediana de 4 meses de idade, com 36,9\% das crianças sendo amamentadas aos seis meses, caracterizando a tendência de crescimento do aleitamento natural (VICTORA et al., 1993).

SENA (1997) observou no Distrito Federal a prevalência de $60 \%$ para o grupo de crianças com seis meses de idade.

Estudo realizado em crianças Guarani, dos Estados de São Paulo e Rio de Janeiro, identificou aleitamento prolongado, com 95,5\% das crianças sendo amamentadas aos seis meses de idade (SERAFIM 1997).

Com relação ao aleitamento exclusivo, observa-se a brevidade dessa forma de amamentação na população investigada. $\mathrm{Na}$ análise comparativa das estimativas de prevalência de aleitamento exclusivo em outros inquéritos, observa-se a situação desfavorável das crianças indígenas.

Em Santos (1992) a prevalência de aleitamento materno exclusivo para crianças com um mês de idade foi de 47\% (PÉREZ-ESCAMILLA et al., 1995). No Distrito Federal (1994) foi de 54\% (SENA 1997).

Com relação à introdução de outros líquidos, além do leite materno, observou-se introdução precoce e desnecessária, considerando que, crianças amamentadas exclusivamente até os seis meses de idade, não necessitam receber outros alimentos. Estudos comprovam que esta prática pode levar à diminuição da freqüência e intensidade de sucção, reduzindo a produção de leite materno, além do risco de infecções, pela contaminação de mamadeiras ou dos próprios alimentos oferecidos à criança. A complementação com outros alimentos e líquidos nãonutritivos, está associada, também, a uma diminuição do volume do leite materno, indicando que a criança que recebe complemento ingere menos leite por mamada, 
além de reduzir o número das mesmas (JELLIFFE e JELLIFFE 1979; AKRE 1989; HORTA et al., 1996).

Quanto à decisão de amamentar, os resultados indicam o forte componente cultural, agindo favoravelmente à amamentação, mesmo com a ausência de estímulos e orientações por parte dos serviços locais de assistência à saúde.

O estado nutricional infantil depende basicamente do consumo alimentar e do estado de saúde da criança. Estudos demonstram que o potencial de crescimento infantil de diferentes populações de todo o mundo são semelhantes quando são adequadas as condições de saúde e nutrição (HABICHT et al., 1974; MARTORELL et al., 1976; KELLER 1988).

Os valores encontrados neste estudo demonstram elevada prevalência de déficits de estatura/idade $(11,1 \%)$, ultrapassando a freqüência de $2,3 \%$ esperada pela distribuição de referência (NCHS) e indicando desnutrição crônica, possivelmente iniciada ainda no útero materno.

Para qualificar a prevalência de crianças com déficits de estatura/idade, comparou-se com estimativas da PNSN (1989) e PNDS (1996), onde se verifica que a prevalência de retardo de crescimento na população indigena é superior à encontrada na população da região centro-oeste, provavelmente refletindo as condições sócioeconômicas de populações indígenas, representadas pela baixa renda familiar, carência de alimentos, falta de atenção à saúde, precárias condições de saneamento e baixa escolaridade dos pais.

Segundo a PNSN (1989), a prevalência de retardo de crescimento linear infantil era de $8,2 \%$ para a região Centro-Oeste (FIBGE. 1992). Na PNDS (1996) foram observados $10,5 \%$ de déficits de estatura/idade para as crianças brasileiras menores de cinco anos (BENFAM 1996).

A prevalência de déficits de estatura/idade foi inversamente proporcional à escolaridade materna e à faixa de renda familiar, mais elevada na Aldeia Córrego do Meio, em crianças de baixo peso ao nascer, menor circunferência do braço, residentes em domicílios com água proveniente de rios e poços rasos e sem instalação sanitária. Sob o ponto de vista imediato, essas variáveis poderiam ser assumidas como elementos de predição de risco e indicação de grupos alvo de programas assistenciais.

Crianças nascidas com menos de $2500 \mathrm{~g}$ apresentavam $25,0 \%$ de déficits de estatura/idade, em contraste com $2,4 \%$ para as crianças nascidas com 3500 ou mais 
gramas. Evidencia-se assim a importância do peso ao nascer como um indicador para a vigilância nutricional em recém-nascidos.

Estudos indicam a associação entre desnutrição infantil e o aumento na incidência e severidade de enfermidades infecciosas, retardo do desenvolvimento psicomotor, dificuldades no aproveitamento escolar, diminuição da altura na idade adulta e elevação das taxas de mortalidade na infância (MARTORELL et al., 1992; TOMKINS e WATSON 1989).

Esses resultados indicam que ações de recuperação nutricional devem ser rapidamente incorporadas à programação de assistência à saúde indígena, considerando que, em crianças com déficit de crescimento linear poderá haver reversibilidade do déficit estatural se houver condições adequadas de recuperação, com atendimento que contemple os diversos aspectos envolvidos.

$\mathrm{Na}$ faixa etária de 12 a 23 meses foram observados os maiores valores de retardo de crescimento linear, período de grande vulnerabilidade devido à dependência aos suprimentos alimentares do domicílio.

A influência da renda sobre o estado nutricional infantil tem sido verificada em diversos estudos. Na PNSN (1989) crianças com retardo de crescimento estavam concentradas nas famílias cuja renda mensal era inferior a dois salários mínimos. (MINISTÉRIO DA SAÚDE 1990).

MONTEIRO e BENÍCIO (1988) destacam a renda familiar como o ponto comum entre os diversos modelos teóricos explicativos do estado nutricional. As formas de ação da renda estariam condicionando tanto o consumo de alimentos como o acesso a bens e serviços básicos e estes, indiretamente, propiciariam melhor aproveitamento biológico dos nutrientes ingeridos.

Comparando com estudos realizados em outras comunidades indígenas, a prevalência de desnutrição infantil observada é inferior às reportadas por grupos indígenas da região amazônica. Em 1987, entre crianças Suruí menores de cinco anos, a prevalência de retardo de crescimento infantil era de 50,6\% (COIMBRA JUNIOR e SANTOS 1991).

Estudo realizado em crianças Parakanã foram observados 53,5\% em 1989, 48,1\% em 1990 e 50,6\% em 1991 (MARTINS e MENEZES 1994).

Entre os Xavante, na avaliação nutricional de crianças com 0 a 4 anos, foi encontrada a prevalência de 27,7\% no ano de 1994 e 22,0\% em 1995 (GUGELMIM, 1995). 
A prevalência de déficits de peso/estatura $(1,1 \%)$ foi baixa entre os Terena, mas é importante notar que estudos de observação transversal não são adequados para aferição de prevalência de desnutrição aguda.

Em estudo realizado entre os Enawene-Nawe, foram encontradas as prevalências de $5,6 \%$ de déficits de peso/estatura e $50 \%$ de déficits de estatura/idade (WEISS 1998). Apesar da gravidade da situação nutricional observada nessas comunidades indigenas, alguns autores referem tais resultados às características étnicas e genéticas desses povos. Essa interpretação difere da observada neste estudo, onde os resultados estariam indicando o retardo de crescimento sendo o reflexo direto da pobreza a que estão submetidos, incluindo aí a deficiência alimentar continuada.

Os resultados observados nas diferentes aldeias estudadas, especialmente as diferenças entre a Aldeia Tereré e as demais, reforçam a origem nas condições de vida a que estão submetidos, uma vez que os integrantes pertencem à mesma etnia, mesma família (parentes consangüíneos) e que lá residiam antes de migrarem em busca de emprego, escola e assistência à saúde. As diferenças encontradas são significativas e provavelmente estão relacionadas às melhores condições de vida na Aldeia Tereré.

Em comunidade indigena Terena, localizada em perímetro urbano de Campo Grande, Mato Grosso do Sul, com projetos de assistência à saúde, geração de renda e saneamento básico, a prevalência encontrada foi de $9,5 \%$ de retardo de crescimento (RIBAS et al., 1999). Esta comparação poderia estar indicando a possível ação benéfica de medidas preventivas e assistenciais, agindo sobre as condições nutricionais de crianças indigenas.

COX (1970) realizou estudo na Austrália, verificando a circunferência cefálica e o peso em recém-nascidos aborígenes, sendo observadas as mesmas medidas de crianças inglesas até os três meses de idade e, a partir daí, apresentavam atraso no crescimento em função das condições de vida.

Em 1980, COCKINGTON realizou inquérito sobre crescimento em três comunidades aborígenes de diferentes condições sociais, encontrando diferenças significativas nos parâmetros de crescimento relacionados com a melhoria das condições de vida. O resultado mostrou que as crianças aborígenes australianas, originárias de ambiente similar ao de crianças caucasianas, apresentavam crescimento normal, não encontrando diferenças significativas entre os grupos. 
Pesquisadores têm registrado um contínuo processo de evolução de estatura em diferentes paises (TANNER 1978; WIERINGEN 1978). As razões apontadas para explicar essa tendência secular são as melhorias das condições de vida, o desenvolvimento da saúde coletiva e a melhoria do estado nutricional.

Modelos teóricos apontam a multicausalidade da desnutrição (MONTEIRO e BENICIO 1981; JONSSON 1986; BEGHIN 1989). De acordo com JONSSON (1986) o modelo causal da fome é representado por uma rede de fatores hierarquicamente encadeados tendo origem na forma como a sociedade mobiliza os recursos potenciais para a produção de bens e serviços e como os distribui entre a população. No nível mais imediato, a fome resulta de ingestão inadequada de alimentos e do estado de saúde dos indivíduos, que por sua vez estão relacionados a fatores que refletem $o$ acesso desigual a produtos, serviços e outros recursos como alimentos, moradia, educação, água, esgoto e serviços de saúde. E a estrutura socioeconômica determina o padrão de produção, distribuição e consumo dessas mercadorias e serviços entre os grupos de indivíduos.

MONTEIRO et al. (1993) analisaram as tendências temporais baseadas na comparação dos resultados de inquéritos antropométricos realizados em âmbito nacional, evidenciando que o padrão de crescimento na infância melhorou nos últimos quinze anos, em todas as regiões do pais, sendo que, as regiões Norte e Nordeste registraram menores valores. Essas evidências acompanham a melhoria de indicadores do nível de escolaridade da população e saneamento ambiental.

O desafio é que, através do conhecimento da vida dos povos indígenas, sejam efetuadas ações que levem essas melhorias às aldeias, sob a égide do princípio da eqüidade. 


\section{CONCLUSÕES}

Os resultados obtidos neste estudo permitem as seguintes conclusões:

As comunidades estudadas caracterizam-se por baixo nível socioeconômico, com baixa renda familiar, insalubridade nos domicílios, deficiente nível de escolaridade dos pais e reduzida extensão territorial produtiva.

Os dados indicam baixo nível de utilização de serviços de assistência à saúde materno-infantil. As famílias que recebem os benefícios são principalmente aquelas que possuem maior facilidade de acesso.

A freqüência de diarréia é alarmante. A diarréia e as infecções respiratórias são as principais causas das internações hospitalares. A incidência de baixo peso ao nascer é superior às incidências nacional e regional.

A amamentação é prolongada, com elevada freqüência e forte componente cultural agindo favoravelmente à amamentação.

O consumo alimentar é caracterizado pela monotonia da dieta, com aporte insuficiente de energia em todos os grupos de idade. O consumo de proteína esteve abaixo das recomendações na dieta das crianças menores de 12 meses e superior para crianças maiores. Os carboidratos tiveram distribuição aproximada das recomendações e as gorduras atingem as recomendações nutricionais para as crianças menores de 6 meses, mas apresentam inadequação a partir desta idade.

O aporte dietético de cálcio ultrapassa as recomendações na dieta das crianças menores de seis meses, tornando-se insuficiente a partir de um ano de idade. Em todas as idades o aporte dietético de vitamina $\mathrm{A}$ e ferro esteve abaixo das quantidades recomendadas. $\mathrm{O}$ aporte de vitamina $\mathrm{C}$ esteve próximo das recomendações de consumo.

Os déficits nutricionais verificados são baixos quando comparados com prevalências de comunidades indígenas da região amazônica, mas superiores às prevalências da região Centro-Oeste e da população brasileira como um todo. A prevalência de déficits de estatura/idade é inversamente proporcional à escolaridade materna e à faixa de renda familiar. São mais elevados em crianças de baixo peso ao nascer, no grupo etário de 12 a 23 meses, com menor circunferência do braço, residentes em domicílios insalubres e distantes dos locais de assistência à saúde. 


\section{CONSIDERAÇÕES FINAIS}

$\mathrm{O}$ que as famílias Terena ofereceram à equipe de pesquisa está além do que foi narrado ou do que se registrou através de fotografias. A acolhida cautelosa transformou-se em olhar profundo, generoso e repleto de significados. Estar entre os Terena enriqueceu-nos, diminuindo o fosso do nosso desconhecimento.

$O$ desafio deste trabalho foi dar forma expressiva e fiel a muitas realidades toscamente desvendadas, sendo considerado apenas como uma primeira aproximação na busca do conhecimento sobre as condições nutricionais de crianças indígenas, necessitando de estudos adicionais.

A sociedade envolvente ignora a existência de comunidades diferenciadas, vivendo em condições perversas. A informação e a compreensão acerca dessas realidades necessitam ser ampliadas.

A saúde, nutrição, educação e acesso à terra devem ser vistos como caminhos para a sobrevivência e autonomia de grupos indígenas.

Os déficits nutricionais observados são reflexos das condições a que estão submetidos, incluindo a deficiência alimentar continuada. A garantia da alimentação para as famílias indígenas depende do acesso à terra de modo a oferecer suficiente produção doméstica.

Este estudo clama por atenção, mudanças e eqüidade, onde ações transdisciplinares e a participação comunitária sejam garantidas a um povo que veio da terra e nela habita para semear. 


\section{REFERÊNCIAS}

1. Akre J. Infant feeding: the physiological basis. Geneva: WHO; 1989.

2. Ariza Macias A, Daza CH, Pradilla A. Fundamentos de um sistema de vigilância alimentaria e nutricional. Boletim de la Oficina Sanitaria Panamericana 1980; 89(6): 538-545.

3. Bairagi R. A comparison of five anthropometric indices for identifying factors of malnutrition. American Journal of Epidemiology 1987; 26(2): 258-267.

4. Baldus H. Os índios Chamacocos e a sua língua. Rev Museu Paulista 1927; 15: 5-63.

5. Batista Filho M. Economia da nutrição. [Apresentado ao Seminário de Economia da Nutrição; 1978; Recife, Brasil].

6. Batista Filho M, Shiraiwa $T$. Indicadores de saúde para um sistema de vigilância nutricional. Cad Saúde Pública. Rio de Janeiro 1989; 5(1): $105-$ 116.

7. Beghin I, Cap M, Dujardin B. Guia para evaluar el estado de nutrición. Washington (DC); 1989. (OPAS - OMS - publicación científica, 515).

8. Bemfam. Pesquisa nacional sobre demografia e saúde. Relatório Preliminar. Rio de Janeiro: Bemfam; 1996.

9. Berg A. The nutrition factor: its role in national development. Washington: The Brooking Institution; 1973. 
10. Bittencourt AS, Leal MC, Rivera J. Diarrhea and growth among children under 18 months of age in Rio de Janeiro. Bulletin of PAHO 1993; 27(2): 135-144.

11. Black RE, BROWN KH, BECKER S. Effects of diarrhea associated with specific enteropathogens on the growth of children in rural Bangladesh. Pediatrics 1984; 73: 799-805.

12. Bourée $P$, David P, Coco O, David-Julien MC. Influence des transformations socio-economiques sur l'etat nutritionnel des enfants de la tribu Cashibo. Bull Soc Pathologie Exotique 1985; 78: 101-109.

13. Brasil. Constituição da República Federativa do Brasil. São Paulo: IMESP; 1988.

14. Brasil. Decreto lei $\mathrm{n}^{\circ} 5371$, de 5 de dezembro de 1967. Autoriza a instituição da Fundação Nacional do Índio e dá outras providências. Diário Oficial da República Federativa do Brasil, Brasília, 6 dez 1967.

15. Brasil. Decreto lei $\mathrm{n}^{\circ} 6001$, de 19 de dezembro de 1973. Dispõe sobre o Estatuto do Índio. Diário Oficial da República Federativa do Brasil, Brasília, $21 \mathrm{dez} 1973$.

16. Brasil. Lei Orgânica do SUS nº 8080 de 19 de setembro de 1990. Brasília: ACS; 1990.

17. Buchillet D. A questão da integração dos sistemas médicos: problema e perspectivas. Uma introdução. In: Buchillet $\mathrm{D}$, organizadora. Medicinas tradicionais e medicina ocidental na Amazônia. Belém: Cejup. UEP. MPEG; 1991. p. 243-6.

18. Buchillet D. Interpretação da doença e simbolismo ecológico entre os índios Desana. Bol Museu Paraense Emílio Goeldi 1988; 4(1): 27-42. 
19. Buchillet D. Algumas reflexões sobre tuberculose, cultura e antropologia. [Apresentado no I Seminário de Saúde Indígena; 2000 maio 10; Campo Grande, MS Brasil].

20. Bustamante MAS. Utilização dos serviços de saúde materno-infantis na região sudoeste da grande São Paulo 1989-1990. São Paulo; 1996 [Dissertação de Mestrado - Faculdade de Saúde Pública - Universidade de São Paulo].

21. Cameron N. The measurement of human growth. London: Croom Helm; 1984.

22. Cardoso $\mathrm{AD}$. Visóneu. Uma reflexão sobre o idoso Terena da Aldeia Tereré, através do Rorschach. Campo Grande; 1999 [Dissertação de Mestrado - Universidade Católica Dom Bosco].

23. Carraza FR, Marcondes E. Nutrição clínica em pediatria. São Paulo: Sarvier; 1991.

24. Carvalho F. Xamanismo e cura entre os Terena. Araraquara; 1987. [Monografia - Universidade Estadual de São Paulo].

25. Castro IRR. Vigilância alimentar e nutricional: limitações e interfaces com a rede de saúde. Rio de Janeiro: Fiocruz; 1995.

26. Centers for Disease Control. Word Health Organization. Epi Info. Epidemiologia em microcomputadores [programa de computador]. Geneve:WHO; 1994.

27. Cintra IP, Heyde MED, Schmitz BAS, Franceschini SCC, Taddei JA, Sigulem DM. Métodos de inquéritos dietéticos. Cad Nutrição 1997; 13:11-23. 
28. Cleland JG, Van Ginneken GK. Maternal education and child survival in developing countries: the search for pathways of influence. Soc Sci Med 1988; 27:1357-68.

29. Cochrane SH, O'Hara DJ, Leslie J. The effects of education on health. Washington (DC); 1980. (World Bank - Paper 405).

30. Cockington RA. Growth of Australian aboriginal children related to social circunstance. Aust N Z J Med 1980; 10: 199.

31. Coimbra Júnior CEA, Santos RV. Avaliação do estado nutricional num contexto de mudança socioeconômica: o grupo indígena Suruí do Estado de Rondônia, Brasil. Cad Saúde Pública 1991; 7 (4): 538-562.

32. Coimbra Júnior CEA, Santos RV. Saúde, minorias e desigualdades: algumas teias de inter-relações, com ênfase nos povos indígenas no Brasil. Ciência \& Saúde Coletiva 2000; 5: 125-132.

33. Coimbra Júnior CEA. Estudos de ecologia humana entre os Suruí do Parque Indígena Aripuanã, Rondonia: aspectos alimentares. Bol Museu Paraense Emílio Goeldi Antropologia 1985; 2: 57-87.

34. Coimbra LC, Mochel EG. Assistência pré e perinatal. In: Tonial SR, Silva AAM (orgs). Saúde, nutrição e mortalidade infantil no Maranhão. São Luís: UFM/UNICEF; 1997. p. 30-35.

35. Condon-Paoloni D. Morbity and growth of infants and young children in a rural Mexican village. Am J Public Health 1977; 67:651-6.

36. Confalonieri UEC. O sistema único de saúde e as populaçãoes indígenas. Por uma integração diferenciada. Cad Saúde Pública 1989; 5(4): 441-56. 
37. Confalonieri UEC. Perfis epidemiológicos. In: Confalonieri UEC et al., org. Saúde de populações indígenas - uma introdução para profissionais de saúde. Rio de Janeiro: ENSP, FIOCRUZ; 1993. p.15-26.

38. Conselho Indigenista Missionário. Saúde indígena. [on line]. 2000 [6]. http: \lwww.cimi.org.br/saude.htm [2000 Dez 15].

39. Conselho Indigenista Missionário. Situação jurídica das terras indígenas. [on line]. 1997 [10]. http://www.cimi.org.br/situacaojur.htm [1999 Mar 18].

40. Costa DC. Política indigenista e assistência à saúde. Noel Nutels e o serviço de unidades sanitárias aéreas. Cad Saúde Pública 1987; 4 (3): 388-401.

41. Cox JW. Growth characteristics of preschool aboriginal children. Aust Pard J 1970; 15: 10.

42. Cozzolino SMF. Biodisponibilidade de minerais. Rev Nutrição 1997; 10(2): 87-98.

43. Daniel-Ribeiro CT. Vacinas: negócio de estado? Cad Saúde Pública 1995; 11(1): 137-41.

44. Dietary reference intakes. Nutr Rev 1997; 55(9): 319-26.

45. Donaldson PJ, Billy JGO. The impact of prenatal care on birth weight: evidence from na international data set. Med Care 1984; 22: 177-188.

46. Eveleth PB, Tanner JM. Worldwide variation in human growth. London: Cambridge University; 1976.

47. Eveleth PB. Population differences in growth: environmental and genetic factors. In: Falkner F, Tanner M. org. Human growth. New York: Plenum Press; 1986. 
48. Faundes A, Cecatti JG. Operação cesárea no Brasil: incidência, tendências, causas, conseqüências e propostas de ação. Cad Saúde Pública 1991; 7(2): $150-73$.

49. Fernandes J. Índio. Esse nosso desconhecido. Cuiabá: UFMT; 1993.

50. Fundação IBGE. Fundo das Nações Unidas para a infầncia. Instituto Nacional de Alimentação e Nutrição. Perfil estatístico de crianças e mães no Brasil. Aspectos de saúde e nutrição no Brasil 1989. Rio de Janeiro; 1992a.

51. Fundação IBGE. Fundo das Nações Unidas para a infância. Instituto Nacional de Alimentação e Nutrição. Crianças e adolescentes: indicadores sociais. Rio de Janeiro; 1992b.

52. Fundação IBGE. Estudo nacional da despesa familiar - consumo alimentar - antropometria. Rio de Janeiro; 1978.

53. Fundação IBGE. Pesquisa Nacional por amostra de domicílios. Rio de Janeiro; 1989.

54. Fundação IBGE. Censo demográfico 1991 Mato Grosso do Sul. Rio de Janeiro; 1994.

55. Fundação IBGE. Pesquisa Nacional por amostra de domicílios. Rio de Janeiro; 1999.

56. Fundação Nacional de Saúde. Saúde indígena. [online] 1997 [9]. Disponível em <URL: http://www.fns.gov.br/acoes/saude.htm $>$ [2001 Mai 21].

57. Fundação Nacional do Índio. Quantos são e onde estão os índios hoje? [online] 1995; [4] Disponivel em <URL: http://www.funai.gov.br/indios8.htm> [1999 Jan 27]. 
58. Galeazzi MAM. O desafio dos anos 90. In: FAO. Seminário Nacional de Abastecimento: fome - o desafio dos anos 90. São Paulo, 1991. p.37-44.

59. Gillespie S, John K, John M. Controlling iron deficiency. Genebra; 1991 (ONU).

60. Goldenberg P. Repensando a desnutrição como questão social. São Paulo: Cortez; 1989.

61. Gomes MP. Os índios e o Brasil. Petrópolis: Vozes; 1988.

62. Gomez F, Galvan RR, Frenk S et al. Mortality in second and third degree malnutrition. J Tropical Pediatrics 1956; 2 (2): 77-83.

63. Gomez F. Desnutricion. Bol Méd Hosp Infan Méx 1946; 3(4): 543-551.

64. Gugelmim AS. Nutrição e alocação de tempo dos Xavantes de Pimentel Barbosa, Mato Grosso: um estudo em ecologia humana e mudanças. Rio de Janeiro; 1995. [Dissertação de Mestrado - Escola Nacional de Saúde Pública - Fundação Oswaldo Cruz].

65. Gupta MC. Intestinal parasitic infections and malnutrition. Ind J Pediat 1980; 47:503-509.

66. Habicht JP, Martorell R, Yarbrough C et al. Height and weight standards for preschool children: how relevant are ethnic differences in growth potential? Lancet $1974 ; 1$ (7858): 611-615.

67. Hamil PVV, Drizo T, Johnson CL et al. Physical growth: national center of health statistics percentiles. Am J Clin Nutr 1979; 32: 693-702.

68. Hardy EE, Sarmento R, Gushiken M, Araki R, Martins FJ. A prática da amamentação no município de Paulínea, Estado de São Paulo, Brasil. Rev Saúde Pública 1982; 16: 337-45. 
69. Hiane PA, Ramos MIL, Ramos Filho MM, Barrocas GEG. Teores de minerais de alguns frutos do Estado de Mato Grosso do Sul. Bol Ceppa 1992; 10(2): 208-214.

70. Hiane PA, Ramos MIL, Ramos Filho MM, Pereira JG. Composição centesimal e perfil de ácidos graxos de alguns frutos nativos do Estado de Mato Grosso do Sul. In: Encontro Nacional de Analistas de Alimentos; 1990 jun; Curitiba, Paraná. Curitiba: ENAAL; 1990. p.79.

71. Horta BL, Olinto MTA, Victora CG, Barros FC, Guimarães PRV. Amamentação e padrões alimentares em crianças de duas coortes de base populacional no sul do Brasil: tendências e diferenciais. Cad Saúde Pública 1996; 12 Suppl1: 43-8.

72. Jelliffe DB, Jelliffe EP. Human milk in the modern world. Oxford: Oxford Med Publ; 1979.

73. Jelliffe DB. Evaluation del estado de nutricion de la comunidad. Ginebra; 1968. (OMS - Série Monográfica, 53).

74. Jonsson V. As causas da fome. In: Valente FLS (org). Fome e desnutrição determinantes sociais. São Paulo: Cortez; 1986. p.48-65.

75. Keller W. The epidemiology of stunting. In: Waterlow JC. Linear growth retardation in less developed countries. Nestlé Nutrition Workshop Series $1988 ; 14: 17-38$.

76. Kincald JC. Perinatal care: organization and outcome. Lancet 1986; 2: 777 778.

77. Kramer MS. Determinants of low birth weight: methodological assessment and meta-analysis. Bull WHO 1987; 65:663-737. 
78. Langdon EJ, MacLennan R. Western biomedical and sibundoy diagnosis: na interdisciplinary comparison. Social Science Med 1979; 13B:211-220.

79. Langdon EJ. Saberes biomédicos e saberes indígenas: um desafio para a política de saúde indígena. Rev Divulgação Cultural 1998; 64: 76-80.

80. Langdon EJ. Saúde indígena: a lógica do processo de tratamento. Saúde Debate 1988; 1 ( $\mathrm{n}^{\circ}$ esp.): $12-15$.

81. Lei DLM. Retardo do crescimento na idade pré-escolar: fatores socioeconômicos, associação com o estado nutricional na idade escolar e prognóstico do aproveitamento discente no município de Osasco. São Paulo; 1994. [Tese de Doutorado - Faculdade de Saúde Pública - Universidade de São Paulo].

82. Levy, MSF. Relação entre situação social e crescimento físico, numa população infantil de Santo André, SP, Brasil. Rev Saúde Pública 1977; 11 (3): 295-321.

83. Lohman TG, Roche AF, Martorell R. Anthropometric standardization reference manual. Illinois: Human Kinetics; 1988.

84. Lucas A. Programming by early nutrition in man. In: Bock GR, Whelan J. The childhood environment and adult disease. Chichester: Wiley; 1995. p.38-35.

85. Mangolim $\mathrm{O}$. Da escola que o branco faz à escola que o índio necessita e quer: uma educação indígena de qualidade. Campo Grande; 1999. [Dissertação de Mestrado - Universidade Católica Dom Bosco].

86. Mangolim O. Povos indígenas no Mato Grosso do Sul: viveremos por mais 500 anos. Campo Grande: CIMI/MS; 1993.

87. Maranhão AGK, Joaquim MMC, Siu C. Mortalidade perinatal e neonatal no Brasil. Um desafio para os serviços de saúde. Tema Radis 1999; 17: 6-17. 
88. Marcondes E. Normas para o diagnóstico e a classificação dos distúrbios do crescimento e da nutrição. Pediat 1982; 4:307-326.

89. Marr JW. Individual dietary surveys: purposes and methods. World Rev Nutr Diet 1971; 13:105-164.

90. Martins SJ, Menezes RC. Evolução do estado nutricional de menores de 5 anos em aldeias indígenas da tribo Parakanã, na Amazônia Oriental Brasileira 1989-1991. Rev Saúde Pública 1994; 28(1): 1-8.

91. Martorell R, Yarbrough C, Lechtig A, Delgado H, Hlein RE. Upper arm anthropometric indicators of nutritional status. Amer J Clin Nutr 1976; 29(1): 46-53.

92. Martorell R. Notes on the history of nutritional anthropometry. Nutr Anthropology 1981; 40(11): 2572-2576.

93. Martorell R. Rivera J, Kaplowitz H, Pollitt E. Long-term consequences of growth retardation during early childhood. In: Hernandez M, Argente J, editors. Human growth: basic and clinical aspects. Amsterdam: Elsevier; 1992. p. 143-9.

94. Mason JB, Habicht J, Tabatabai H, Valverde V. Vigilância nutricional. Genebra, Organizacion Mundial de la Salud; 1984.

95. Ministério da Previdência e Assistência Social. Secretaria de Assistência Social. Manual para avaliação antropométrica do estado nutricional de crianças até 7 anos de idade. Brasília; 1983.

96. Ministério da Saúde. Assistência integral à saúde da criança: ações básicas. Brasilia; 1984a.

97. Ministério da Saúde. Assistência integral à saúde da mulher: bases de ação programática. Brasília; 1984b.

BibliolecedCIR 
98. Ministério da Saúde. Atendimento integrado à saúde e desenvolvimento da criança. Brasília; 1992.

99. Ministério da Saúde. Fundação Nacional de Saúde. II Conferência nacional de saúde indígena. Brasília; 1993.

100. Ministério da Saúde. I Conferência nacional de saúde indígena. Brasília; 1987.

101. Ministério da Saúde. Instituto Nacional de Alimentação e Nutrição. Pesquisa nacional de saúde e nutrição: perfil de crescimento da população brasileira de 0 a 25 anos. Brasília; 1990.

102. Ministério da Saúde. Instituto Nacional de Alimentação e Nutrição. Programa nacional de incentivo ao aleitamento materno. Brasília; 1991.

103. Ministério da Saúde. Instituto Nacional de Assistência Médica da Previdência Social. Assistência e controle das doenças diarreicas - ações básicas na assistência integral à saúde da criança. Brasília; 1985.

104. Ministério da Saúde. Instituto Nacional de Assistência Médica da Previdência Social. Acompanhamento do crescimento e desenvolvimento. Brasília; $1986 a$.

105. Ministério da Saúde. Instituto Nacional de Assistência Médica da Previdência Social. Aleitamento materno e orientação alimentar para o desmame. Brasília; $1986 b$.

106. Ministério da Saúde. Instituto Nacional de Assistência Médica da Previdência Social. Assistência e controle das infecçōes respiratórias agudas. Brasília; 1987.

107. Ministério da Saúde. Manual de vacinação. Brasília; $1984 \mathrm{c}$. 
108. Ministério da Saúde. Secretaria Nacional de Programas Especiais de Saúde. Assistência pré-natal. Brasília; 1988.

109. Mock NB, Bertrand WE. Marco conceptual para los sistemas de vigilancia nutricional. Boletin de la Oficina Sanitaria Panamericana. 1993; 11(6): 511522.

110. Mondini L. Desnutrição e obesidade no Brasil: relevância epidemiológica e padrões de distribuição intra-familiar em diferentes estratos econômicos e regionais. São Paulo; 1996 [ Tese de Doutorado - Faculdade de Saúde Pública Universidade de São Paulo].

111. Monteiro CA, Iunes RF. Diminui a desnutrição infantil. Rev Ciência Hoje $1994 ; 17(100): 20-21$.

112. Monteiro CA, Benício MHD'A, Gouveia NC. Saúde e nutrição das crianças brasileiras no final da década de 80 . In: Monteiro MFG, Cervini $\mathrm{R}$ (orgs). Perfil estatístico de crianças e mães no Brasil. Aspectos de saúde e nutrição de crianças no Brasil 1989. Rio de Janeiro: FIBGE; 1992. p. 19-42.

113. Monteiro CA, Benício MHD'A, Iunes RF, Gouveia NC, Cardoso MAA. Evolução da desnutrição infantil. In: Monteiro CA, organizador. Velhos e novos males da saúde no Brasil. São Paulo: Hucitec, Nupens/USP; 2000a; p.93-114.

114. Monteiro CA, Benício MHD’A, Zuñiga, HPP et al. Estudo das condições de saúde das crianças do município de São Paulo, SP (Brasil), 1984-1985. I. Aspectos metodológicos, características socioeconômicas e ambiente físico. Rev Saúde Pública 1986; 20 (6):435-445.

115. Monteiro CA, Benício MHD’A. Epidemiologia da desnutrição proteicocalórica. In: Nóbrega FJ. Desnutrição intra-uterina e pós-natal. São Paulo: Panamed, 1981. p.120-129. 
116. Monteiro CA, Benício MHD'A. Estado nutricional e renda na cidade de São Paulo. Perspectiva 1988; 1(3): 67-70.

117. Monteiro CA, Freitas ICM, Baratho RM. Saúde, nutrição e classes sociais: o nexo empírico evidenciado em um grande centro urbano, Brasil. Rev Saúde Pública 1989; 23(5): 422-428.

118. Monteiro CA, Mondini L, Souza ALM, Popkin BM. Da desnutrição para a obesidade: a transição nutricional no Brasil. In: Monteiro CA, organizador. Velhos e novos males da saúde no Brasil. São Paulo: Hucitec, Nupens/USP; 2000 b; p. 247-255.

119. Monteiro CA, Mondini L, Souza ALM, Popkin BM. The nutrition transition in Brasil. Eur J Clin Nutr 1995; 49:105-13.

120. Monteiro CA, Szarfarc SC. Estudo das condições de saúde das crianças do Município de São Paulo (1984/85). V. Anemia. Rev Saúde Pública 1987; 21(3): 255-60.

121. Monteiro CA. Estudo antropométrico nutricional de pré-escolares de áreas de baixa renda do Estado de São Paulo, Brasil. Rev Saúde Pública 1984; $18: 1-8$.

122. Monteiro CA. Os determinantes da desnutrição infantil no Vale do Ribeira. Cad Pesq Fund Carlos Chagas 1979; 29: 57-75.

123. Monteiro CA. Saúde e nutrição das crianças de São Paulo. São Paulo: Hucitec; 1988.

124. Monteiro MFG. Baixo peso ao nascer. In: FIBGE. UNICEF. INAN. Perfil estatístico de crianças e mães no Brasil. Aspectos de saúde e nutrição no Brasil 1989. Rio de Janeiro; 1992. p.11-18. 
126. Morais MB, Fagunde Neto U, Baruzzi RG, Prado COM, Wehba J, Silvestrini WS. Estado nutricional de crianças índias do Alto Xingu e avaliação do perimetro braquial no diagnóstico da desnutrição proteico-calórica. Rev Paulista Med 1990; 108(6): 245-251.

127. Nabarro D, Howard P, Cassels C, Pant M, Wijga A, Padfield N. The importance of infections and environmental factors as possible determinants of growth retardation in children. In: Waterlow JC. Linear growth retardation in less developed countries. New York: Kaven Press; 1988. p. 165-83.

128. National Academy of Sciences. Recommended dietary allowances. National Research Council. Washington: National Academy Press; 1989.

129. National Center for Health Statistics. NCHS growth curves for children, birth - 18 years. Washington; 1977.

130. Nóbrega FJ, Vitolo MR, Brasil ALD, Lopez FA. Condição nutricional de mães e filhos: relação com o peso ao nascimento, variáveis maternas $e$ socioeconômicas. J Pediatr 1991; 67 (9/10): 288-96.

131. Nutels N, Miranda JAN. Viragem tuberculínica em grupos indígenas vacinados com BCG intradérmico. Rev Serv Nac Tuberculose 1969; 13 (51): 255-264.

132. Nutels N. Plano para uma campanha de defesa do índios brasileiro contra a tuberculose. Rev Bras Tuberculose 1952; 20 (139): 3-28.

133. Oberg K. The Terena and the Caduveo of Southern Mato Grosso, Brazil. Washington: Institute of Social Anthropology; 1949.

134. Olinto MTA, Victora CG, Barros FC, Tomasi E. Determinantes da desnutrição infantil em uma população de baixa renda: um modelo de análise hierarquizado. Cad Saúde Pública 1993; 9 Suppl 1; 14-27. 
135. Oliveira RC. A sociologia do Brasil indígena. Rio de Janeiro: Tempo Brasileiro; 1978.

136. Oliveira RC. Urbanização e tribalismo. A integração dos índios Terena numa sociedade de classes. Rio de Janeiro: Zahar; 1968.

137. Oliveira SP, Thébaud-Mony A. Estudo do consumo alimentar: em busca de uma abordagem multidisciplinar. Rev Saúde Pública 1997; 31(2):201-208.

138. Organisation Mondiale de la Santé. Soins de santé maternelle et infantile: fiche internationale de croissance - diretives à l'usages des agents de soins de santé primaires. Geneve; 1978.

139. Organización Mundial de la Salud. Medición del cambio del estado nutricional. Ginebra; 1983.

140. Organización Panamericana de la Salud. Organización Mundial de la Salud. Indicadores para evaluar las practicas de lactancia materna. Ginebra; 1991.

141. Osis MJD, Hardy E, Faúnde A, Alves G. Fatores associados à assistência prénatal entre mulheres de baixa renda no Estado de São Paulo, Brasil. Rev Saúde Pública 1993; 27(1): 49-53.

142. Pao EM, Cypel YS. Estimation of dietary intake. In: Ziegler EE, Filer LJ. editors. Present knowledge in nutrition. Washington: Ilsi Press; 1996. P.498507.

143. Pastor AJ, Arroyave G, Flores M, Guzman M, Martorell R. Indicadores del estado nutricional. [Mesa redonda apresentada no Congresso Médico Centroamericano; 1973; San José, Costa Rica]. 
144. Pauletti $M$. O direito indígena no ordenamento brasileiro: uma responsabilidade da União. Campo Grande; 2000. [Dissertação de Mestrado - Universidade Católica Dom Bosco].

145. Pereira AML, Fisberg RM, Brasil ALD, Abreu VJS, Pacheco MEMS, Vasconcelos MIL. Métodos para avaliação do consumo alimentar em crianças e adolescentes. Rev Paulista Pediatria 1997; 15(4): 210-214.

146. Pérez-Escamilla R, Lutter C, Segall AM, Rivera A, Treviño-Siller S, Sanghvi T. Exclusive breast-feeding duration is associated with attitudinal socioeconomic and biocultural determinants in three Latin Americam countries. J Nutr 1995; 125:2972-2984.

147. Philippi ST, Szarfarc SC, Latterza AR. Virtual nutri. [programa de computador]. Versão 1.0 for windows. São Paulo: Departamento de Nutrição. FSP. USP; 1996.

148. Popkin BM, Keyou G, Zhai F, Guo X, Ma H, Zohoori N. The nutrition transition in China: a cross-sectional analysis. Eur J Clin Nut 1993; 47: 333346 .

149. Post CL, Victora CG, Barros FC et al. Desnutrição e obesidade infantil em duas coortes de base populacional no sul do Brasil: tendência e diferenciais. Pelotas: UFP; 1995.

150. Prata PR. Desenvolvimento econômico, desigualdade e saúde. Cad Saúde Pública 1994; 10(3): 387-391.

151. Puffer R, Serrano CV. Características de la mortalidad en la niñez. Publ Cient Org Panam Salud 1973; 262:1-490.

152. Rattner D. Sobre a hipótese de estabilização de taxas de cesárea do Estado de São Paulo, Brasil. Rev Saúde Pública 1996; 30(1): 19-33. 
153. Ribas DLB, Tanaka ACA, Zorzatto JR, Philippi ST. Avaliação do estado nutricional de crianças em Campo Grande, Mato Grosso do Sul, Brasil. In: Anais do XV Congresso Brasileiro de Nutrição; 1998, Brasília. p. 162.

154. Ribas DLB, Tanaka ACA, Zorzatto JR, Philippi ST. Saúde e estado nutricional infantil de uma população da região Centro-Oeste do Brasil. Rev Saúde Pública 1999a; 33(4): 358-65.

155. Ribas DLB, Zorzatto JR, Philippi ST. Nutrição de crianças indígenas. In: Anais do I Congresso Latino Americano de Nutrição Humana; 1999b, Gramado, Brasil. p. 120.

156. Ribas DLB. Avaliação nutricional de crianças menores de cinco anos de idade no município de Campo Grande MS, Brasil. Campo Grande; 1997. [Dissertação de Mestrado - Universidade Federal de Mato Grosso do Sul].

157. Ribeiro D. Os índios e a civilização. Rio de Janeiro: Civilização Brasileira; 1970.

158. Rosa JG. Ave, palavra. Rio de Janeiro: Nova Fronteira; 1985.

159. Rosso PA. New chart to monitor weight gain during pregnancy. American Journal of Clinical Nutrition 1985; $41: 644-652$.

160. Rowland MGM. Impact of infection on the growth of children from 0 to 2 years in na urban West African community. Am J Clin Nutr 1988; 47: 134-8.

161. Sena MCF. Prevalência do aleitamento materno exclusivo no Distrito Federal e sua associação com o trabalho materno fora do lar. Brasília; 1997. [Dissertação de Mestrado - Faculdade de Ciências da Saúde Universidade de Brasília].

162. Serafim MG. Hábitos alimentares e nível de hemoglobina em crianças indígenas Guarani, menores de cinco anos, dos Estados de São Paulo e Rio 
de Janeiro. São Paulo; 1997. [Dissertação de Mestrado - Escola Paulista de Medicina - Universidade Federal de São Paulo].

163. Sganzerla A. A história do Frei Mariano de Bagnaia. Campo Grande: FUCMAT; 1992.

164. Sigulem DM, Alves ELG, Tudisco ES et al. Desnutrição. Uma avaliação crítica dos diferentes enfoques do problema. Saúde em Debate 1978; 6: 16-20.

165. Silva FA. Mudança cultural dos Terena. Rev Museu Paulista 1949; 3: 271 280.

166. Silva MF. A demografia e os povos indígenos no Brasil. Rev Brasileira de Estudos de População 1994; 11(2): 261-264.

167. Simões CCS. O estudo dos diferenciais na mortalidade infantil segundo algumas características socioeconõmicas. In: Monteiro MFG, Cervini R (orgs) Perfil estatístico de crianças e mães no Brasil. Aspectos de saúde e nutrição de crianças no Brasil 1989. Rio de Janeiro: FIBGE, 1992. p.61-78.

168. Sommer A. Vitamin A deficiency and its consequences: a field guide to detection and control - Epidemiology. Genebra: World Health Organization; 1995.

169. Tanner JM. A concise history of growth studies from Buffon to Boas. In: Falkner F, Tanner JM. Human growth. New York: Plenum Press; 1978. p.515-93.

170. Tomkins AM, Watson F. Malnutrition and infection. A review. Geneve: WHO; 1989.

171. Tonete SSQ, Nóbrega FG. Evolução ponder-estatural do recém-nascido desnutrido intra-uterino. In: Nóbrega FJ. Desnutrição intra-uterina e pósnatal. São Paulo: Panamed; 1981. p.258-64. 
172. Trigo $M$. Metodologia de inquérito dietético: estudo do método recordatório de 24 horas. São Paulo; 1993 [Tese de Doutorado- Faculdade de Saúde Pública - Universidade de São Paulo].

173. UNICEF. O progresso das nações. Brasília: UNICEF; 1997.

174. UNICEF. Saúde e nutrição das crianças nordestinas: pesquisas estaduais 1987-1992. Brasília: UNICEF; 1995.

175. UNICEF. Situação mundial da infância 1998. A nutrição em foco. Brasília: UNICEF; 1998.

176. UNICEF. Situação mundial da infância. Brasília: UNICEF; 1991.

177. Vasconcelos CA. A questão indígena na província de Mato Grosso: conflito, trama e continuidade. Campo Grande: UFMS; 1999.

178. Velthen LHV Comer verdadeiramente: produção e preparação de alimentos entre os Wayana. Horizontes Antropológicos 1996; 2(4): 10-26.

179. Victora CG, Barros FC, Halpern R, Menezes AM, Horta BL, Tomasi E, Weiderpass E, Cesar JÁ, Olinto MT, Guimarães PRV, Garcia MM, Vaugham JP. Estudo longitudinal da população materno-infantil da região urbana do sul do Brasil 1993: aspectos metodológicos e resultados preliminares. Rev Saúde Pública $1993 ; 30(1): 34-45$.

180. Victora CG, Barros FC, Vaugham PJ. Epidemiologia da desigualdade. São Paulo: Hucitec; 1988.

181. Victora CG, Barros FC, Vaughan JP, Martines JC, Beria JU. Birthweight, socioeconomic status and groth of brazilian infants. Annals of Human Biology 1987; 14:49-57. 
182. Victora CG, Facchini LA, Barros FC, Lombardi C. Pobreza e saúde: como medir nível socioeconômico em estudos epidemilógicos de saúde infantil. In: Anais do $1^{\circ}$ Congresso Brasileiro de Epidemiologia. Campinas; 1990. p.302315 .

183. Victora CG. The association between wasting and stunting: na international perspective. J Nutr 1992; 122: 1105-10.

184. Waterlow JC, Buzina R, Keller W, Lane JM, Nichaman MZ, Tanner JM. The presentation and use of height and weight data for comparing the nutritional status of groups of children under the age of 10 years. Bull World Health Organ 1977; 55: 489-98.

185. Waterlow JC. Some aspects of chilhood malnutrition as a public health problem. Brit Med J 1974; 4: 88-90.

186. Weiss $\mathrm{MCV}$. Contato interétnico, perfil saúde-doença e modelos de intervenção mínima: o caso Enawene-Nave em Mato Grosso. Rio de Janeiro; 1998. [Tese de Doutorado - Escola Nacional de Saúde Pública Fundação Oswaldo Cruz].

187. Whiting SJ, Mackenzie ML. Assessing the changing diet of indigenous peoples. Nutrition Reviews 1997; 56(8): 248-250.

188. Wieringen JC. Secular growth chenges. In: FalKner F, Tanner JM. Human growth. New York: Plenum Press, 1978.

189. Willems E. Contribuição para o estudo antropométrico dos índios Tereno. Rev Museu Paulista 1947; 1:129-152.

190. Wirsing $\mathrm{R}$. The health of traditional societes and the effects of acculturation. Curr Anthropoly 1985; (26): 303-322. 
191. World Health Organization. Fundo das Nações Unidas para a Infância. Primary health care. Report. Alma Ata; 1978. (International conference on Primary Health Care).

192. World Health Organization. Working Group. Physical status: the use and interpretation of anthropometry. Geneva; 1995. (WHO Technical Report Series, 854). 
ANEXO 1 


\title{
Or.COEP/008/49
}

\author{
0. ke margo de $19 \%$
}

Pele presente, informe que o Comitê de titica cm Pesquisi. aprovou, chis sua

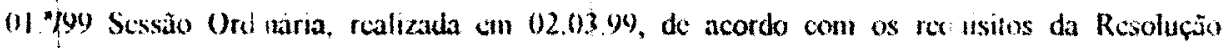

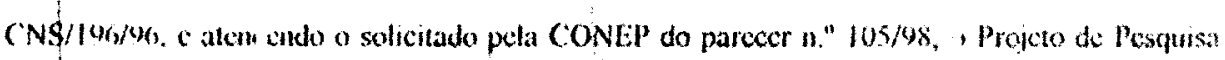
"AVALIACÃO AN IROPONETRICA E CONSUMO ALIMLNTA DL CRIANCAS INDIGENAS TERI: A DL MATOGROSSO DO SUL. BRASIL", iprescntado pela pesquisadera Dulce lopes Barboza Ribas.

Infor no, andn. que a pesquisadora atendeu ao sulceitio. $\mathrm{cm}$ sua tutatidads. apends com una ress Wa for alterado o titulo do projeto de pesquisa que pi sou a constar cono "SAUIDE I NUIRI: TO DE CRIANCAS INDIGENAS TERENA DI: MTO GKOSSO DO SUL BRASII.

Alet tosamente,

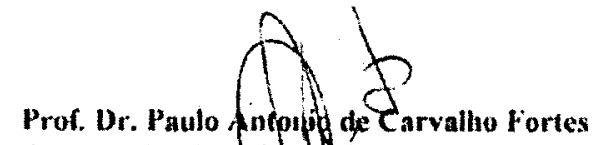

Vice-1 ardenador do Conjte fle fitica em Pesquisa da ESP. OEP

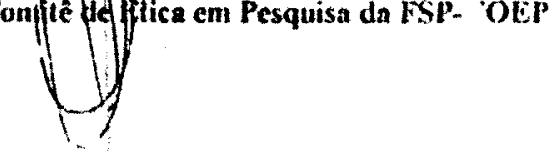

IIni." \$r."

Dr." Corina Bontemp , Duca de Freitas

Secredaria Executiva lo CONE" 
ANEXO 2 


\section{PARECER N० $182 / 99$}

\section{Processo $n^{\circ} 25000.019274198-63 \quad$ REGISTRO CONEP $=271$}

Projeto de Peaquisa: "Saúde e Nutrição de Crianças Indigenas Terena do Mato Grosso do Sul, Brasi"

Pesquisador Responsável: Dra. Dulce Lopes Barboza Ribas

Instituiçăo: Universidade de Săo Paulo/Faculdade Saúde Pública

Área Temática Especial: Projeto em populaçăo indigena

Ao se proceder a análise das respostas ao Parecer 105/98, cabem as seguintes consideraçóes:

a) as informaçóes enviadas atendem aos aspectos fundamentais das Resolucons CNS 196/98, sobre Diretrizes e Normas Regulamantadoras de Pesquisas Envolvendo Seres Humanos;

b) o projeto foi aprovado pelo Comité de Ética em Pesquisa - CEP da institulę̧oso supracitada.

Diante do exposto, Comissăo Nacional de Etica em Pesquisp - CONEP, de acordo com as atribuicóes da Res. CNS 196re6, manifesta-se pela aprovaçăo do projoto de pesquisa proposto.

Brasilia, 23 de abril de 1999 .

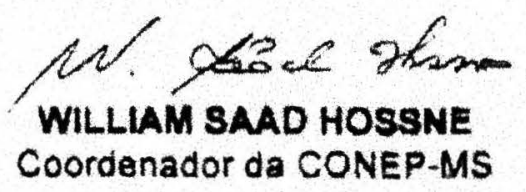


ANEXO 3 


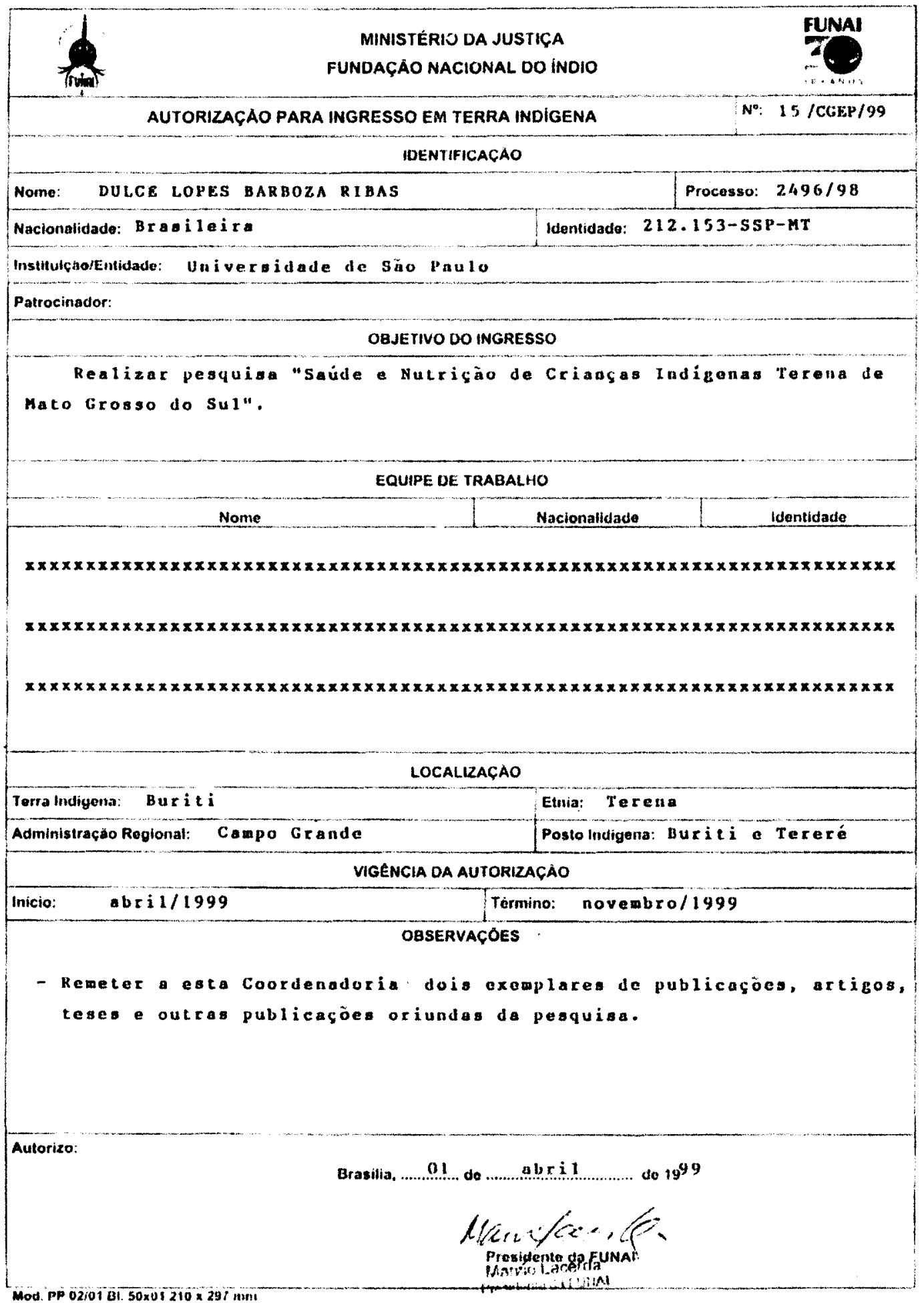


ANEXO 4 


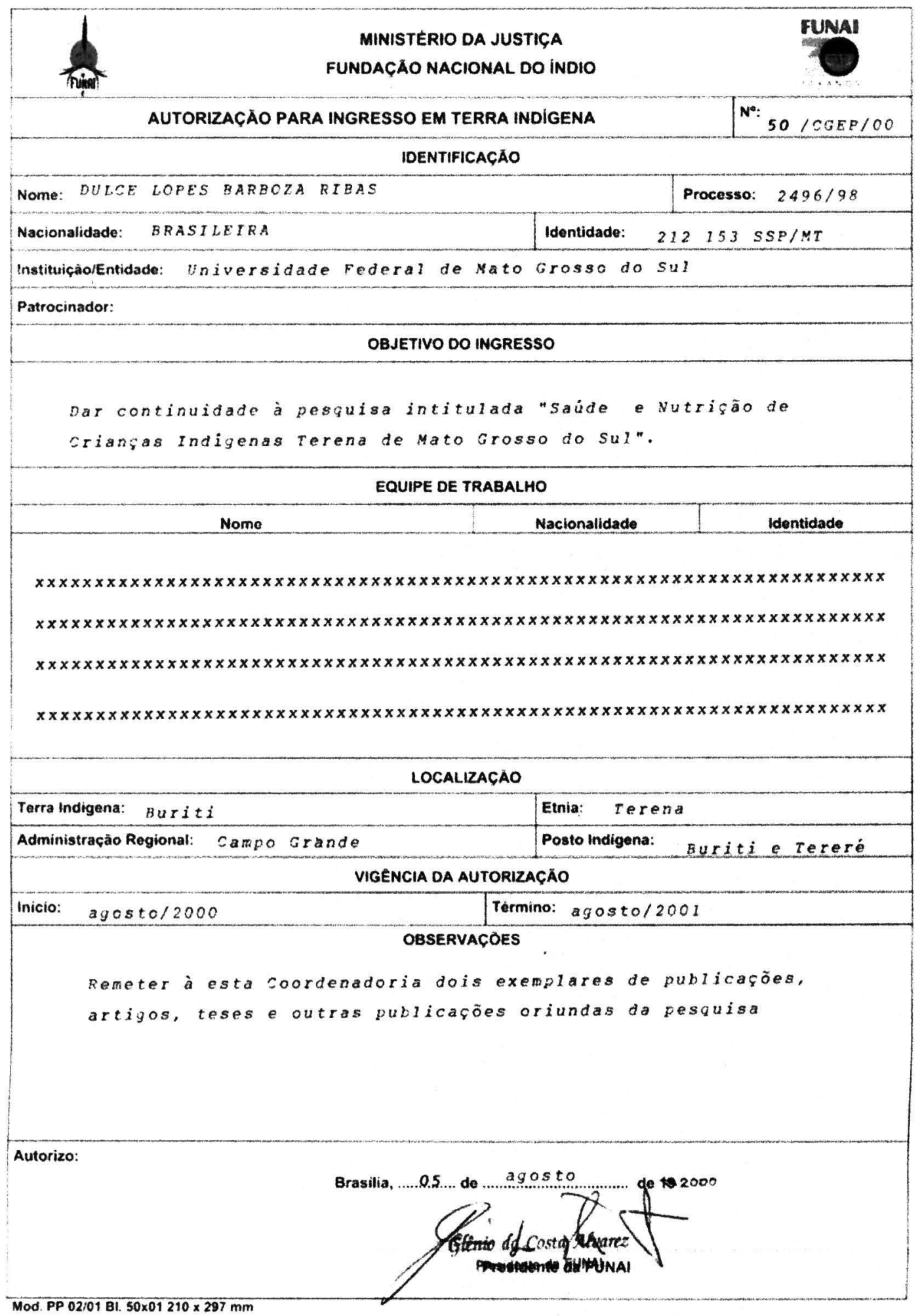


ANEXO 5 


\section{TERMO DE CONSENTIMENTO}

\section{I - Identificação do responsável legal (Pai ou Mãe)}

1.1 Nome

1.2 Natureza (grau de parentesco)

1.3 Documento de identidade

1.4 Data de nascimento ............

1.5 Sexo: $\mathrm{M}(\mathrm{)} \quad \mathrm{F}(\mathrm{)}$

1.6 Endereço:

Cidade:

Estado:

II - Identificação da pesquisa

2.1 Título: Saúde e nutrição de crianças indígenas Terena, Mato Grosso do Sul, Brasil.

2.2 Avaliação do risco da pesquisa:

sem risco (X) risco mínimo ( ) risco médio ( ) risco maior ( )

2.3 Duração total da pesquisa: 20 meses

\section{III - Identificação do pesquisador}

3.1 Nome: Dulce Lopes Barboza Ribas

3.2 Inscrição no Conselho Regional de Nutrição: 4240

3.3 CPF: $229623791-68$

3.4 RG: 212153 SSP/MT

3.5 Profissão: Docente Instituição: Universidade Federal de Mato Grosso do Sul

3.6 Endereço: Rua Itiquira, 247 Bairro Santa Fé Campo Grande, MS

Cep $79021290 \quad$ Telefone: (067) 7263372

3.7 Graduado em Nutrição Instituição: Universidade Federal de Mato Grosso

3.8 Titulação acadêmica: Mestre em Saúde Pública

3.9 Vinculação acadêmica atual: Pós-Graduação - Doutorado Instituição: FSP/USP

\section{IV - Registro das explicações do pesquisador ao representante legal}

4.1 Objetivos da pesquisa:

Conhecer o estado de saúde e nutrição da criança através das medidas do peso, altura, tamanho do braço e avaliação da dieta.

Conhecer o tipo e a quantidade de alimentos que a criança come.

Ter informações sobre o modo de preparo, os utensílios usados, o tipo de produtos usados e número de refeições que a criança recebe.

Ter informações sobre a produção de alimentos na terra disponível, a prática da caça, da pesca e coleta de frutos silvestres, bem como da utilização desses alimentos pela família.

Conhecer as condições de moradia da família e as características do local em que vive a criança.

Conhecer a situação econômica da família, sua renda, o nível de escolaridade dos pais e informações sobre o trabalho que realizam.

Ter informações sobre a idade dos pais, o número de filhos, os cuidados de saúde que as mães tiveram durante a gravidez e como foi o parto.

Conhecer as condições de saúde da criança, quais são as doenças que ela têm, quais os cuidados que a criança recebe e aonde é atendida quando tem problemas de saúde.

Ter informações sobre a amamentação da criança. 


\subsection{Procedimentos}

A família será visitada de duas a três vezes, com duração máxima de 60 minutos cada visita.

As visitas serão marcadas com antecedência, e só serão realizadas com a permissão dos pais.

Os pais serão entrevistados pelos pesquisadores.

As entrevistas serão gravadas.

Serão tiradas fotografias durante as visitas ou realizadas pequenas filmagens. Essas fotografias e filmagens serão utilizadas somente para melhor apresentar os resultados da pesquisa.

As crianças e as mães serão pesadas e medidas.

\subsection{Possiveis desconfortos}

A presença dos pesquisadores poderá provocar inibição (timidez) nos familiares.

A criança poderá não aceitar ser medida ou pesada.

\subsection{Benefícios que poderão ser obtidos}

Informaçðes sobre as condiçðes de saúde e nutrição das crianças, com acesso aos dados resultante da pesquisa.

Novos conhecimentos que possam prevenir problemas de saúde e nutrição em crianças indigenas.

Transporte gratuito até um serviço de saúde para as crianças que estiverem doentes por ocasião do estudo.

Disponibilidade de atendimento nutricional durante a realização do estudo.

\section{V - Garantias}

Acesso a qualquer tempo às informações sobre procedimentos, riscos e benefícios relacionados à pesquisa, inclusive para tirar eventuais dúvidas.

Liberdade de retirar seu consentimento a qualquer momento e de deixar de participar do estudo, sem que isto traga algum prejuizo.

Salvaguarda da confidencialidade, sigilo e privacidade.

\section{VI - Consentimento}

$\mathrm{Eu}$

Declaro que após convenientemente esclarecido pelo pesquisador e depois de ter entendido o que me foi explicado, consinto com a participação na pesquisa denominada "Saúde e nutrição de crianças indígenas brasileiras -Terena, MS."

Data:

$$
\text { Assinatura do responsável pela criança (pai ou mãe) }
$$

Data:

Assinatura do pesquisador

Data: 
ANEXO 6 


\section{SAÚDE E NUTRIÇÃO DE CRIANÇAS INDÍGENAS TERENA}

\section{A - IDENTIFICACÃO}

NUM INQUÉRITO

DATA DA ENTREVISTA:
ÁREA INDÍGENA:

\section{SITUAÇÃO JURÍDICA DA TERRA}

NOME DO ENTREVISTADO

B - FAMÍLIA

Nome da criança.

Data nascimento

Nome da mãe.

Data de nascimento

Nome do pai.

Data de nascimento

1. Idade da criança
(1) $0-5 \mathrm{~m}$
(2) $6-11 \mathrm{~m}$
(3) $12-23 \mathrm{~m}$
(4) $24-59 \mathrm{~m}$

2. Quantos filhos nascidos vivos a Sra. teve até hoje?
(1)... $n^{\circ}$ de filhos vivos

(2) não sabe

3. Quantos filhos nascidos mortos a Sra. teve?
(1)
$n^{\circ}$ de filhos mortos
(2) não teve filhos nascidos mortos
(3) não sabe

4. Teve algum aborto?

(1) sim

(2) não

Se teve, quantos?

5. Dos filhos que teve, quantos estão vivos?

(1) ........................ $n^{\circ}$ de filhos vivos

(2) não sabe

6. A Sra. sabe ler e escrever?

(1) $\operatorname{sim}$

(2) não

7. Qual é o nível de escolaridade da mãe?

(1) Sem instrução

(2) 1 - 4 anos

(3) $5-8$ anos

(4) $>8$ anos 
8. O Sr. sabe ler e escrever?
(1) $\operatorname{sim}$
(2) กão

9. Qual é o nível de escolaridade do pai?

(1) Sem instrução

(2) 1 - 4 anos

(3) $5-8$ anos

(4) $>8$ anos

10. Quanto tempo o (a) Sr (a) mora neste local?

(1) menos de 1 ano

(2) 1 a 4 anos

(3) 5 a 10 anos

(4) há mais de 10 anos

(5) não sabe informar

11. Quantas pessoas moram nesta casa?

(1) 3 a 4 moradores

(2) 5 a 6

(3) $>6$

(4) não sabe informar

12. O Sr (a) está trabalhando atualmente?

(1) $\operatorname{sim}$

(2) não

Se sim, qual o tipo de trabalho o Sr. (a) faz?

13. Por favor, eu gostaria de saber qual é a sua renda (dinheiro) mensal e das outras pessoas que moram nesta casa. Se possível, diga-me o valor aproximado do rendimento mensal que o (a) $\mathrm{Sr}$ (a) percebe regularmente, isto é, no mês passado, quanto ganharam as pessoas desta casa?

(1) rendimento total da família RS _

(2) não sabe

(3) não tem nenhum rendimento

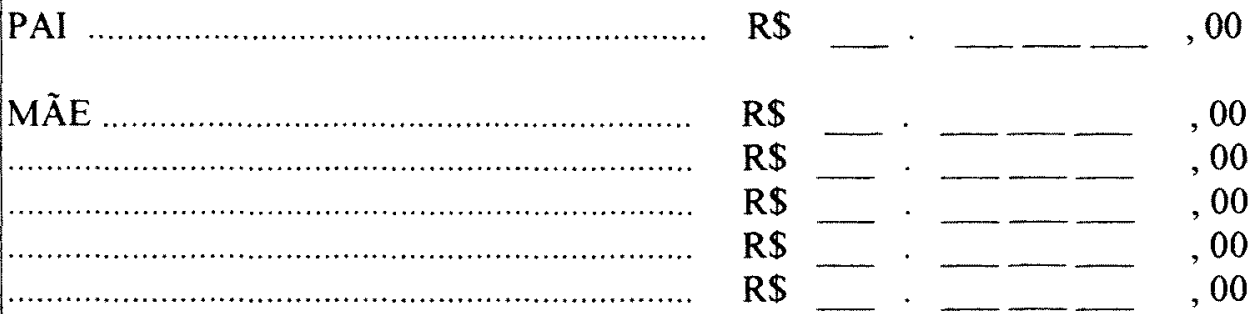

14. Renda per capita (salário mínimo)

(1) 0 - 0,50

(2) $0,50-1,00$

(3) $\geq 1,00$

OBSERVAÇÕES: 


\section{C - HABITAÇÃO (observar e anotar)}

15. Esta casa tem banheiro ou sanitário ?

(1) sim, só do domicílio

(2) sim, comum a mais de um domicílio

(3) não tem

Se sim, aonde está ligado o sanitário? (escoadouro)

(1) vala negra

(2) sanitário ligado a fossa rudimentar

(3) céu aberto

(4) outra situação

Descreva características do sanitário

16. Como é o abastecimento da água utilizada ?

(1) rede geral de distribuição

(2) nascente ou rio

(3) utiliza água de poço

(4) outra situação

Descreva características do a abastecimento

17. O que é feito com o lixo da casa?

(1) coleta pública regular

(2) queima

(3) jogado em terreno baldio

(4) outra situação

Descreva características do tratamento de lixo

18. Como é o sistema de iluminação?

(1) elétrica

(2) motor diesel

(3) lamparina querosene

(4) outra situação

19. Como são as paredes da casa?

(1) alvenaria

(2) madeira

(3) palha

(5) outro material

Descreva características das paredes

20. Qual o material da cobertura?

(1) telha

(2) palha

(3) outro material

Descreva características da cobertura

21. Qual é o revestimento do piso?

(1) cerâmico

(2) cimentado

(3) chão batido

(4) outro

Descreva características do piso

22. Quantos cômodos existem na casa da família?

(1) 1 - 3 cômodos

(2) 4 - 6 cômodos

(3) $>6$ cômodos

Descreva características dos cômodos

Quantos servem para dormir? 
23. Que equipamentos existem na casa ? Assinale os existentes.

( ) geladeira

( ) freezer

( ) fogão a gás

( ) televisão

( ) rádio

( ) aparelho de som

D - CRIANÇA (substituir a palavra "criança" pelo nome)

24. Sexo da criança

(1) masculino

(2) feminino

25. Aonde a "criança" nasceu?

(1) hospital

(2) aldeia

(4) outro

Caso tenha sido no domicílio, quem fez o parto?

Correu tudo bem?

26. Como foi o parto?

(1) normal

(2) cesáreo

(3) outro

27. Qual a duração da gestação? A "criança" nasceu no tempo certo?

(1) pré-termo (menos de 37 semanas)

(2) a termo ( 37 a 41 semanas)

(3) pós-termo (42 semanas e mais)

28. Com quantos quilos nasceu a "criança" ?

(1) igual ou inferior a $2500 \mathrm{~g}$

(2) de 2501 a $3000 \mathrm{~g}$

(3) de 3001 a $3500 \mathrm{~g}$

(4) de 3501 a $4000 \mathrm{~g}$

(5) superior a $4000 \mathrm{~g}$

(6) não sabe informar

29. Na gestação da "criança" a Sra. fez pré-natal ?

(1) $\operatorname{sim}$

(2) não

Se realizou, aonde fez o pré-natal?

30. Quantas vezes consultou durante a gestação da "criança"?

(1) até 3 vezes

(2) 4 a 6 vezes

(5) 7 a 9 vezes

(6) mais de 9 vezes

(7) não sabe informar

(8) não realizou pré-natal

31. A partir de quando a Sra. passou a ter assistência pré-natal?

(1) primeiro trimestre

(2) segundo trimestre

(3) terceiro trimestre

(4) não teve assistência pré-natal

(6) não sabe informar

Como ia à consulta? 
32. A "criança" faz acompanhamento do crescimento? (realiza pesagens periódicas?)

(1) $\operatorname{sim}$

(2) não

Se realiza acompanhamento periódico do crescimento aonde ela faz?

Quando foi pesada pela última vez?

33. Quando a "criança" está doente ou precisa de médico com urgência, aonde a Sra. a leva?

Nome da instituição/local/ quem atende ....

34. Qual a distância da casa até o serviço de saúde mais próximo?

Como chega até o serviço de saúde?

35. A"criança"realizou consulta médica ou de enfermagem nos últimos seis meses ?

(1) $\operatorname{sim}$.

(2) não

Se realizou consulta, qual foi o motivo da consulta?

36. A "criança" foi hospitalizada nos últimos seis meses?

(1) não sabe informar

(2) não foi internada

(3) sim, foi hospitalizada vezes

Se foi hospitalizada, qual foi a causa ?

(1) diarréia

(2) doença respiratória

(3) diarréia com doença respiratória

(4) outros motivos (especificar)

Ela sarou?

37. Atualmente a "criança" apresenta algum problema de saúde?

(1) sim

(2) não

Em caso afirmativo, qual o problema?

(1) doença do coração

(2) doença do fígado

(3) doença dos rins

(4) bronquite

(5) pneumonia

(6) tuberculose

(7) diabetes

(8) outras doenças (especificar)

38. A "criança" está com diarréia hoje?

(1) $\operatorname{sim}$

(2) กão

39. A "criança" teve diarréia nos últimos quinze dias?

(1) $\operatorname{sim}$

(2) não

40. Como está a situação vacinal da "criança" ?

(1) vacinas em dia

(2) vacinas com atraso

(3) nunca foi vacinada

(5) outra situação 


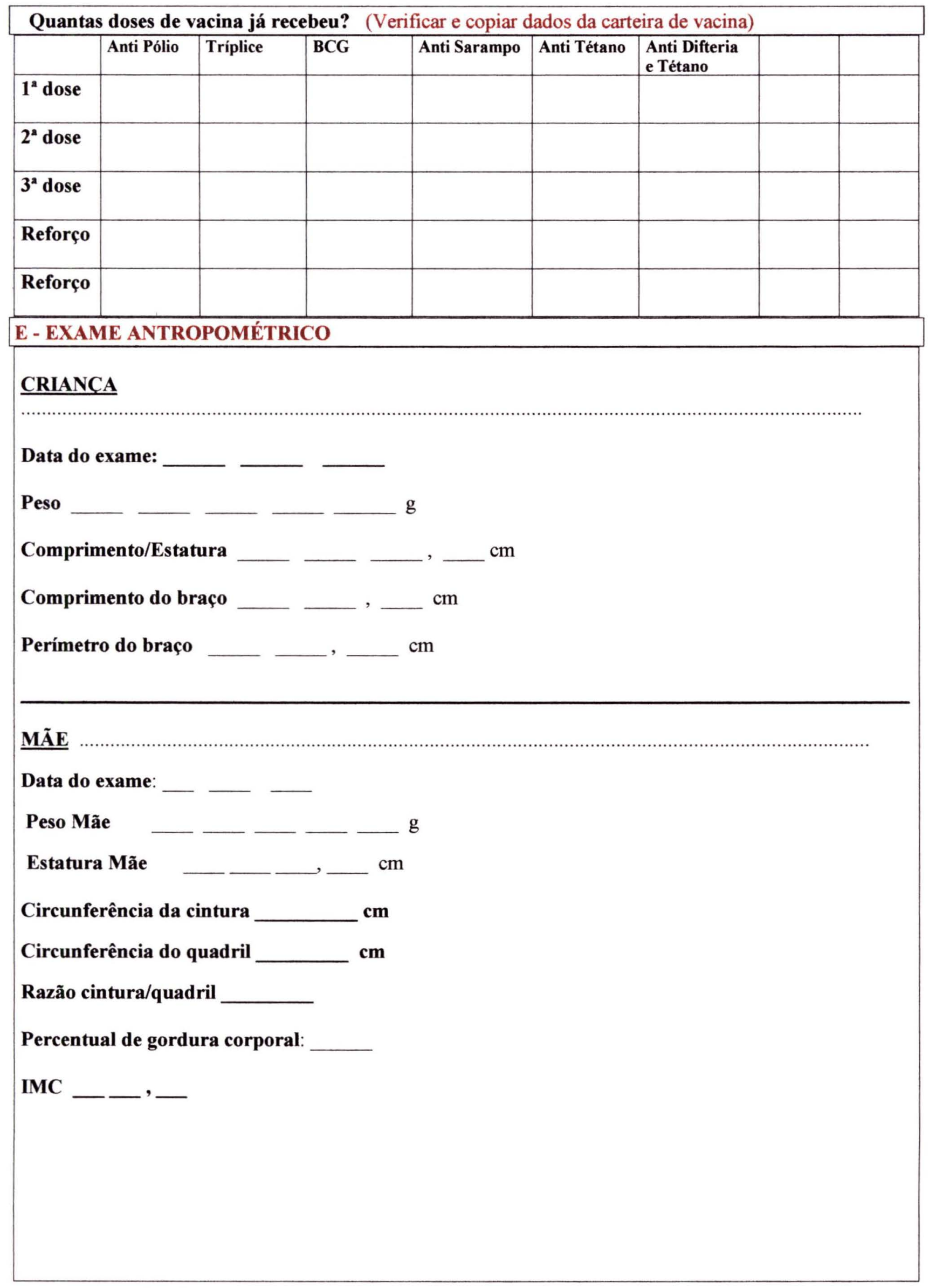




\section{F - ALIMENTOS}

1. Existe o cultivo de hortas, pomar ou roça?

(1) $\operatorname{sim}$ (especificar)

(2) não

Descreva a horta, pomar e roça

Quem planta?

Quem colhe?

2. Existe a criação de animais para consumo ou comercialização ?

(1) $\operatorname{sim}$ (especificar)

(2) não

Como é a criação de animais?

3. Se existe produção de vegetais ou animais o que é feito?

(1) consumo próprio da família

(2) distribuído entre outras famílias da comunidade

(3) vende parte da produção

(4) vende toda a produção

(5) outra situação

(6) não sabe informar

Se existe distribuição da produção entre as famílias, como ela ocorre?

4. A família utiliza a prática da caça?

(1) $\operatorname{sim}$ (especificar)

(2) não

Quem caça?

Quando e como caça?

5. A família utiliza a pesca?

(1) $\operatorname{sim}$ (especificar)

(3) não

Quem pesca?

Quando pesca?

6. A família coleta frutos silvestres?

(1) $\operatorname{sim}$ (especificar)

(3) não

Quem coleta frutos?

O que faz com os frutos coletados?

7. Observar e descrever os principais utensílios utilizados no preparo e oferecimento da dieta à "criança". Verificar se possível a dimensão e capacidade volumétrica dos utensílios.

Utensílios utilizados no preparo:

Utensílios utilizados no oferecimento da dieta para a criança:

Colheres:

Copos:

Pratos:

Pires:

Mamadeira

Caneca:

Outros:

Quem prepara o alimento?

Utiliza que fogão?

A que horas as refeições se realizam?

Quem serve primeiro? 


\section{G - AMAMENTAÇÃO}

8. A "criança" mama no peito?
(1) sim
(2) não

Se sim, quantas vezes ao dia dá o peito?

(1) livre demanda (toda hora/direto/ quando ele chora/sempre que está com fome)

(2) com horários fixo $(2 / 2 \mathrm{~h} ; 3 / 3 \mathrm{~h} ; \ldots$ )

(3) outro esquema

9. A Sra. dá só o peito?
(1) $\operatorname{sim}$
(2) não
( ) água
) chá
( ) suco
( ) outro leite
( ) mingau
( ) sopa
（） só dá o peito

10. Dá alguns destes líquidos? (Atenção, se necessário marcar mais de uma alternativa)

11. Se já foi desmamada, que idade tinha quando deixou de mamar no peito?
(1) meses ou dias
(2) não se aplica
(3) não sabe informar

12. Recebeu orientações sobre amamentação ou incentivos para amamentar?

(1) $\operatorname{sim}$

(2) não

Se sim, aonde recebeu orientação?

Quem orientou? 


\section{H - AVALIAÇÃO DA ENTREVISTA}

(Essas questões devem ser respondidas imediatamente após deixar a casa do entrevistado)

1. Qual o tempo de duração da entrevista?

minutos

\section{2. $O$ entrevistado entendeu as perguntas formuladas?}

(1) satisfatóriamente
(2) insatisfatóriamente

3. Qual foi a reação do entrevistado com a entrevista?
(1) negativa
(4) positiva
(5) outra

4. Quais as questões foram mais dificeis de serem formuladas?

(1) questões $\mathbf{n}^{\circ}$.

(2) não houve dificuldades

5. A entrevista foi prejudicada por outras pessoas ou distrações?

(1) não prejudicadas

(4) moderadamente prejudicadas

(5) muito prejudicadas

6. Anote outras observações que você julga importante com relação ao questionário

7. Nome do entrevistador

8. Data:

\section{ANÁLISE DA COORDENAÇÃO}




\section{CONSUMO DE ALIMENTOS - RECORDATÓRIO DE 24 HORAS}

Data:

Nome da criança

A senhora poderia me dizer tudo o que a "criança" comeu ou bebeu desde ontem cedo (a hora em que acordou) até a hora em foi dormir à noite?

Neste momento só importa saber o que comeu ontem.

Anotar a marca comercial dos produtos industrializados.

\begin{tabular}{|c|c|c|c|c|c|}
\hline Refeição & Horário & Alimentos & Preparação & Unidade & Quantidade \\
\hline & & & & & \\
\hline & & & & & \\
\hline & & & & & \\
\hline & & & & & \\
\hline & & & & & \\
\hline & & & & & \\
\hline & & & & & \\
\hline & & & & & \\
\hline & & & & & \\
\hline & & & & & \\
\hline & & & & & \\
\hline & & & & & \\
\hline & & & & & \\
\hline & & & & & \\
\hline & & & & & \\
\hline & & & & & \\
\hline & & & & & \\
\hline & & & & & \\
\hline & & & & & \\
\hline & & & & & \\
\hline & & & & & \\
\hline & & & & . & \\
\hline & & & & & \\
\hline & & & & & \\
\hline & & & & & \\
\hline & & & & & \\
\hline & & & & & \\
\hline & & & & & \\
\hline & & & & & \\
\hline & & & & & \\
\hline & & & & & \\
\hline & & & & & \\
\hline & & & & & \\
\hline & & & & & \\
\hline & & & & & \\
\hline & & & & & \\
\hline
\end{tabular}




\begin{tabular}{|c|c|c|c|c|c|}
\hline \multicolumn{6}{|c|}{ FREQÜÊNCIA DE CONSUMO DE ALIMENTOS } \\
\hline ALIMENTO / PREPARAÇÃO & QUANTIDADE & DIÁRIO & SEMANAL & MENSAL & NUNCA \\
\hline CEREAIS E DERIVADOS & & & & & \\
\hline ARROZ COZIDO & & & & & \\
\hline AVEIA & & & & & \\
\hline BISCOITOS & & & & & \\
\hline CEREAIS,FARINHA "NESTON" & & & & & \\
\hline MACARRÃo & & & & & \\
\hline MILHO VERDE COZIDO & & & & & \\
\hline MILHO, FUBÁ & & & & & \\
\hline PÃO & & & & & \\
\hline TRIGO, FARINHA & & & & & \\
\hline VEGETAIS E DERIVADOS & & & & & \\
\hline ABÓBORA & & & & & \\
\hline ABOBRINHA & & & & & \\
\hline ALFACE & & & & & \\
\hline ALMEIRÃO & & & & & \\
\hline AMENDOIM & & & & & \\
\hline BATATA DOCE & & & & & \\
\hline BATATA INGLESA & & & & & \\
\hline BETERRABA & & & & & \\
\hline CARÁ & & & & & \\
\hline CEBOLA & & & & & \\
\hline CEBOLINHA & & & & & \\
\hline CENOURA & & & & & \\
\hline CHUCHU & & & & & \\
\hline COUVE & & & & & \\
\hline FEIJÃO & & & & & \\
\hline GUARIROBA & & & & & \\
\hline INHAME & & & & & \\
\hline MANDIOCA & & & & & \\
\hline MANDIOCA, FARINHA & & & & & \\
\hline QUIABO & & & & & \\
\hline REPOLHO & & & & & \\
\hline VAGEM & & & & & \\
\hline TOMATE & & & & & \\
\hline FRUTAS E DERIVADOS & & & & & \\
\hline ABACAXI & & & & & \\
\hline ARATICUM & & & & & \\
\hline ARAÇÁ & & & & & \\
\hline BANANA & & & & & \\
\hline CAJU & & & & & \\
\hline GOIABA & & & & & \\
\hline GENIPAPO & & & & & \\
\hline JATOBÁ & & & & & \\
\hline LARANJA & & & & & \\
\hline LIMÃO & & & & & \\
\hline MAMÃO & & & & & \\
\hline MANGA & & & & & \\
\hline MELANCIA & & & & & \\
\hline PEQUI & & & & & \\
\hline & & & & & \\
\hline
\end{tabular}


FREQÜÊNCIA DE CONSUMO DE ALIMENTOS

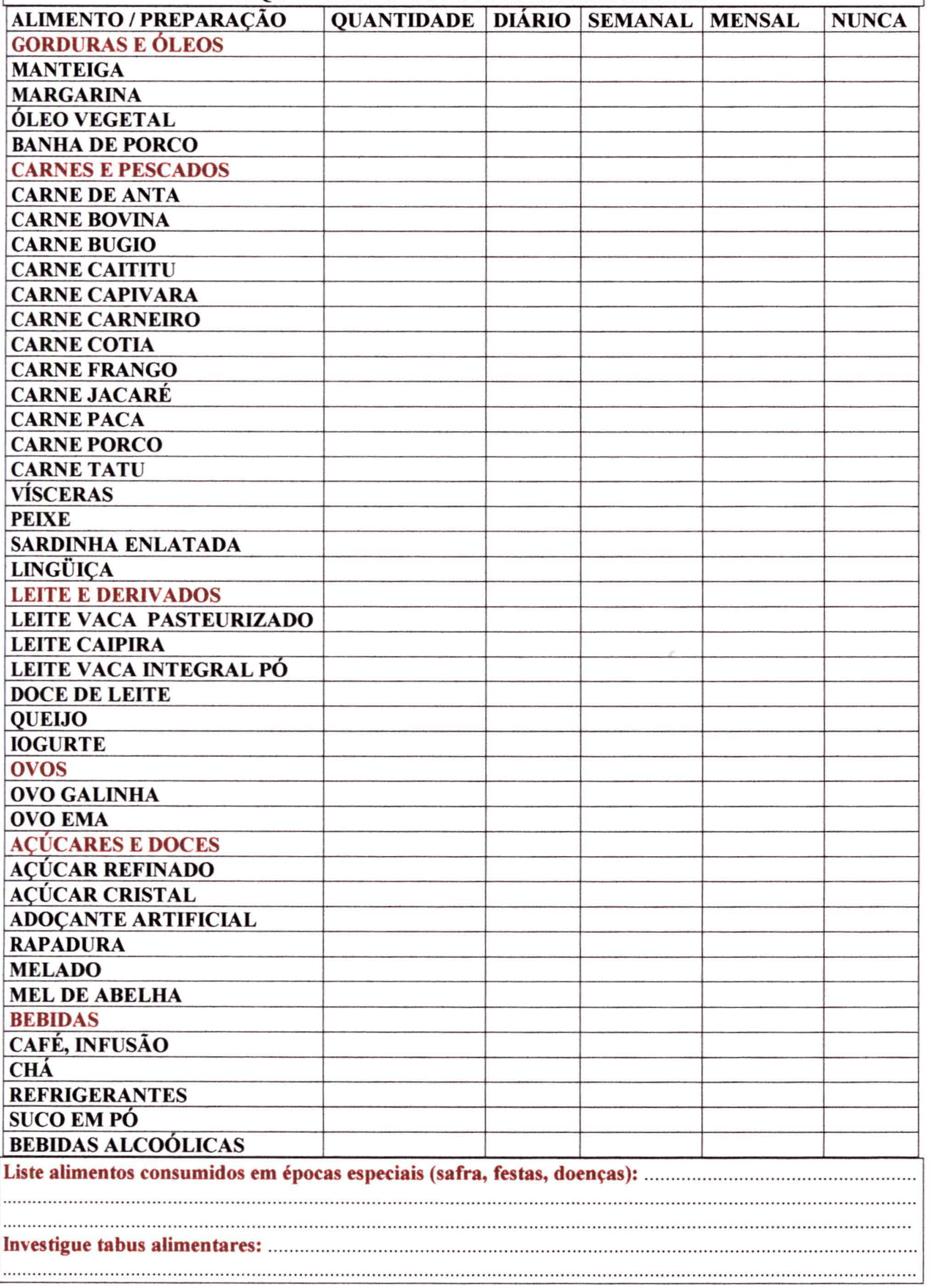


ANEXO 7 


\begin{tabular}{lllll}
\hline $\begin{array}{l}\text { ÁREA } \\
\text { INDíGENA }\end{array}$ & MUNICÍPIO & POPULAÇÃO & $\begin{array}{l}\text { SUPERFÍCIE } \\
\text { DA ÁREA } \\
\text { (Hectare) }\end{array}$ & $\begin{array}{l}\text { DISTRIBUIÇÃO } \\
\text { Hectare/Habitante }\end{array}$ \\
\hline Aldeinha & Anastácio & 376 & 4 & 0,01 \\
\hline Limão Verde & Aquidauana & 1.446 & 1.581 & 1,09 \\
\hline Taunay/Ipegue & Aquidauana & 3.800 & 6.461 & 1,70 \\
\hline Cachoeirinha & Miranda & 3.500 & 2.648 & 0,75 \\
\hline Lalima & Miranda & 1.780 & 3.001 & 1,68 \\
\hline Pilade Rebuá & Miranda & 1.874 & 208 & 0,11 \\
\hline Nioaque & Nioaque & 1.980 & 3.029 & 1,52 \\
\hline Dourados & Dourados & $1.500+7.487$ & 3.530 & 0,39 \\
\hline Água Limpa & Rochedo & $\mathbf{8 1}$ & 12 & 0,14 \\
\hline Buritizinho & Sidrolândia & $\mathbf{2 3 0}$ & $\mathbf{1 0}$ & $\mathbf{0 , 0 4}$ \\
\hline Buriti & Dois Irmãos do & $\mathbf{1 . 0 6 5}$ & $\mathbf{2 . 0 9 0}$ & $\mathbf{1 , 9 6}$ \\
& Buriti & & & \\
\hline Áreas indigena Terena & & &
\end{tabular}

\section{Áreas indígenas Terena no Estado de Mato Grosso do Sul}

${ }^{1} \mathrm{~A}$ área indígena Dourados é composta por habitantes Terena (1.500) e Guarani-Kaiová

(7.487) o que representa 0,39 hectare/pessoa 
ANEXO 8 


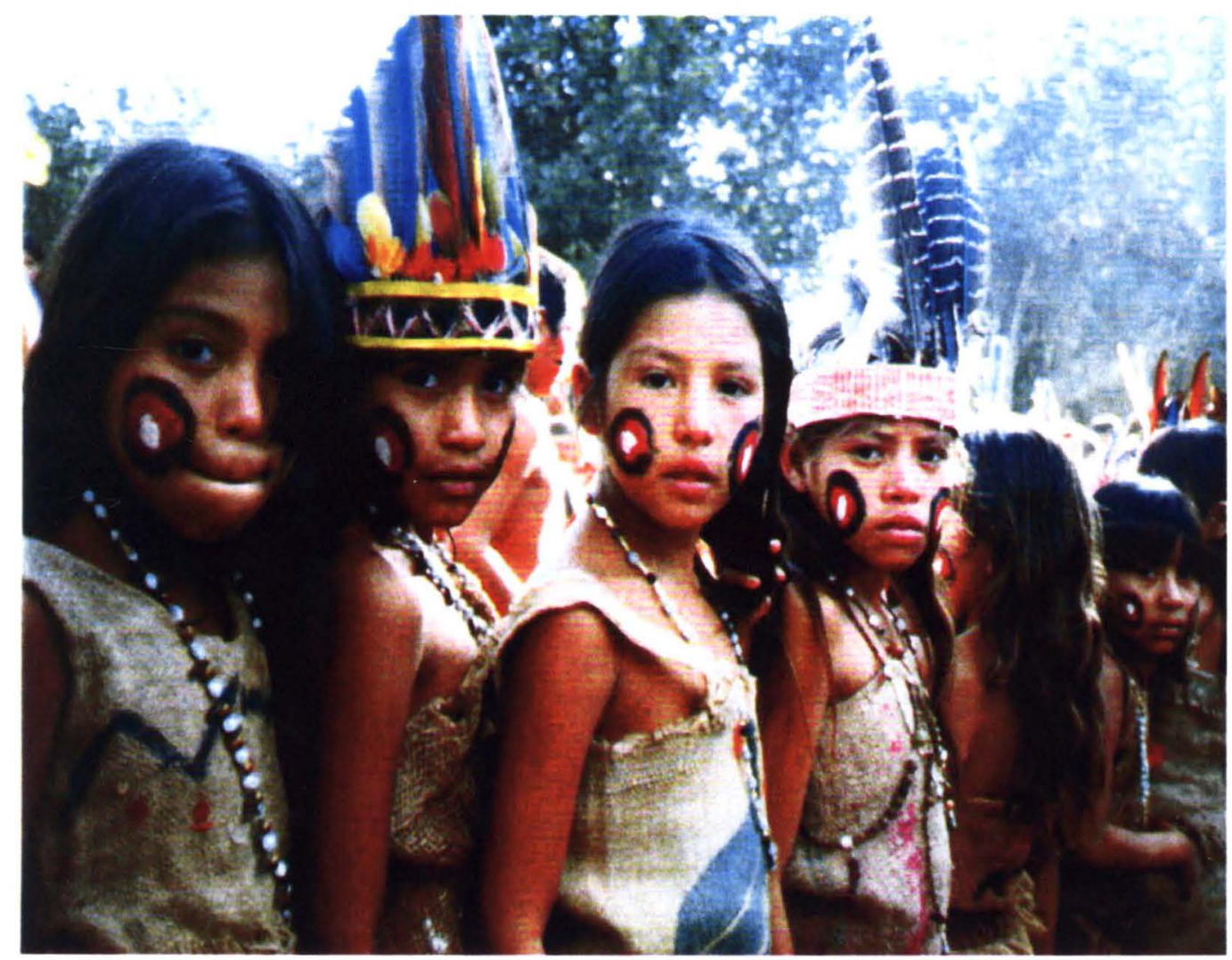

A Dança da Siputrena

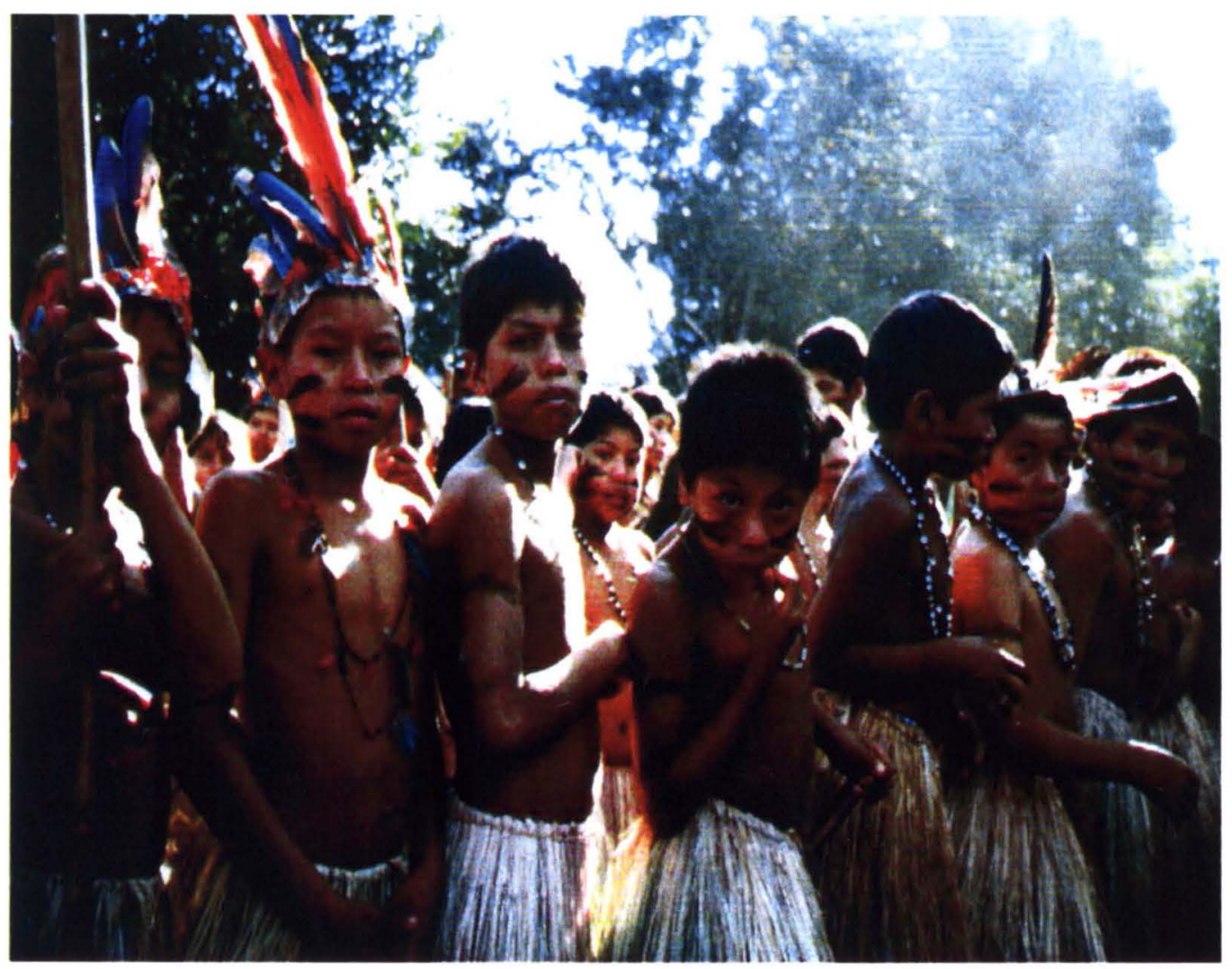

A Dança da Ema 

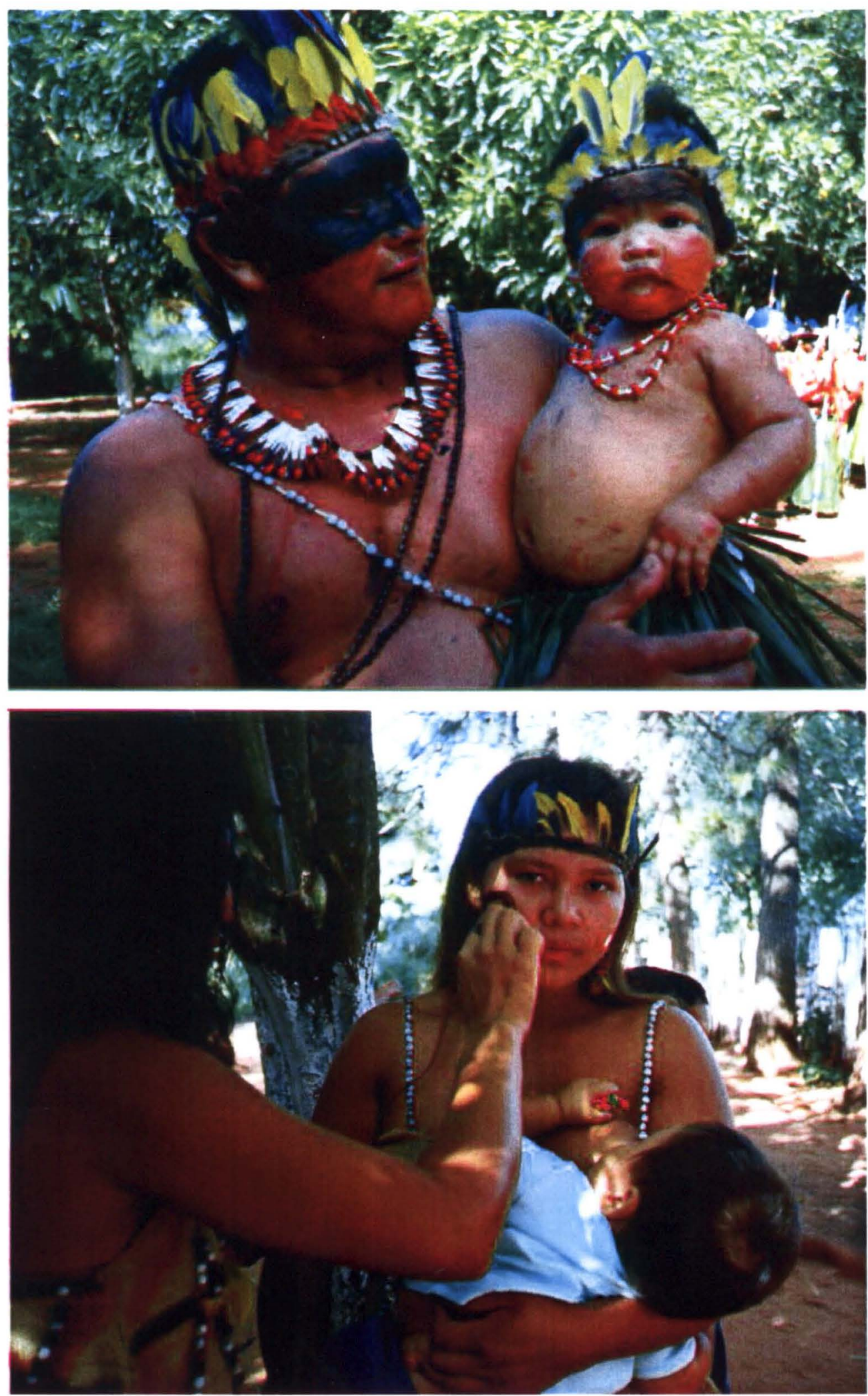

Pintura corporal 


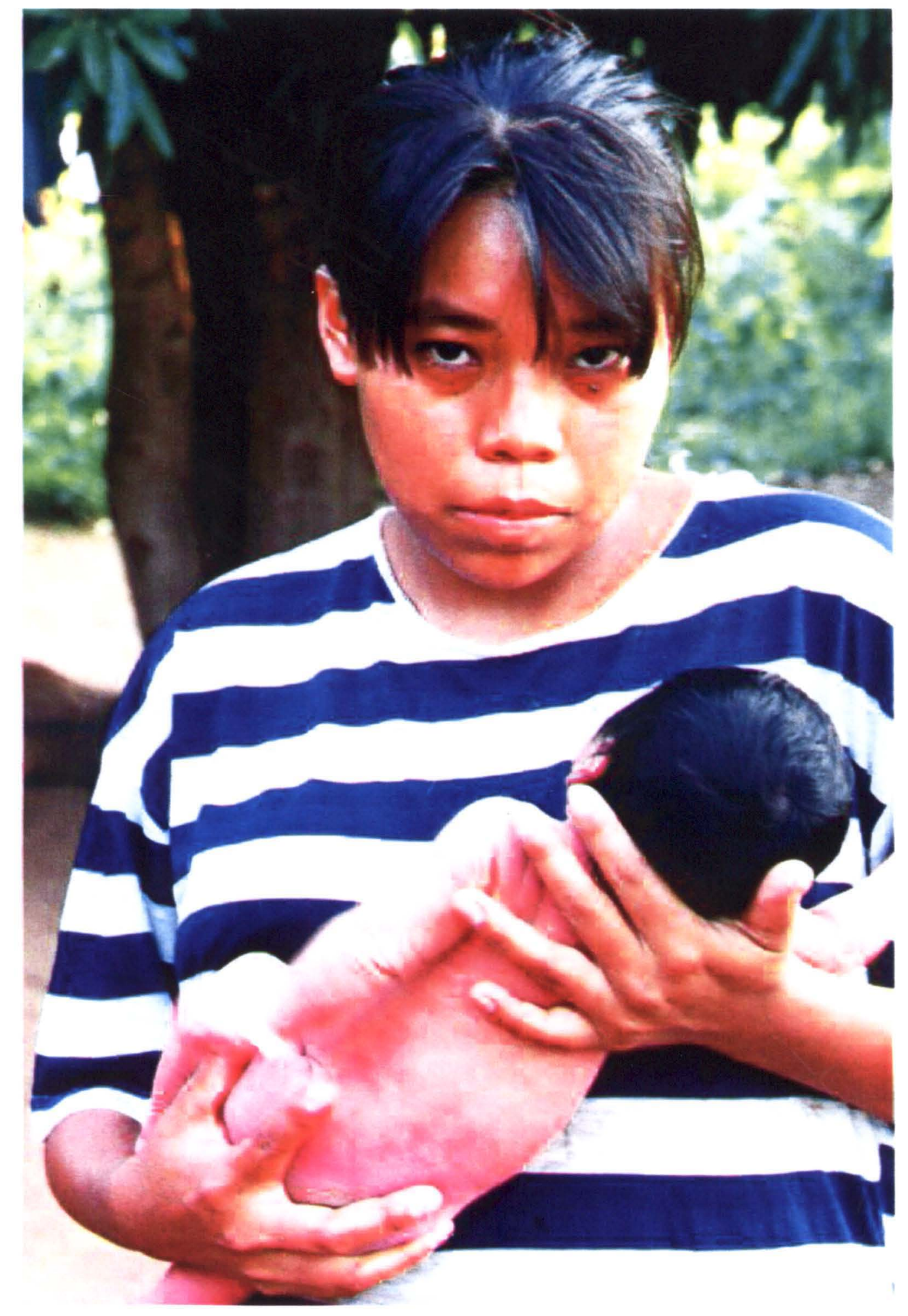

O filho recém-nascido 


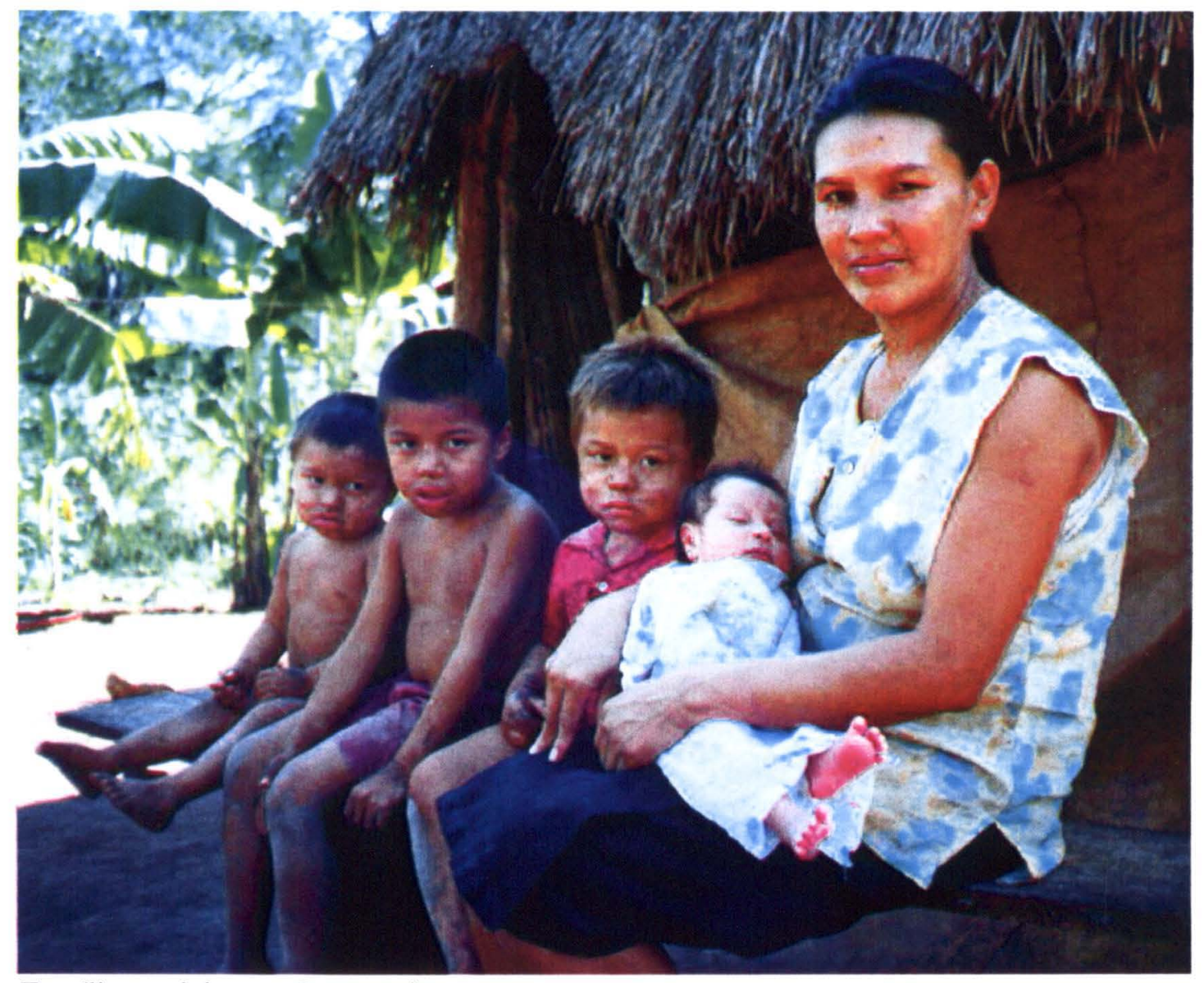

Família participante da pesquisa 


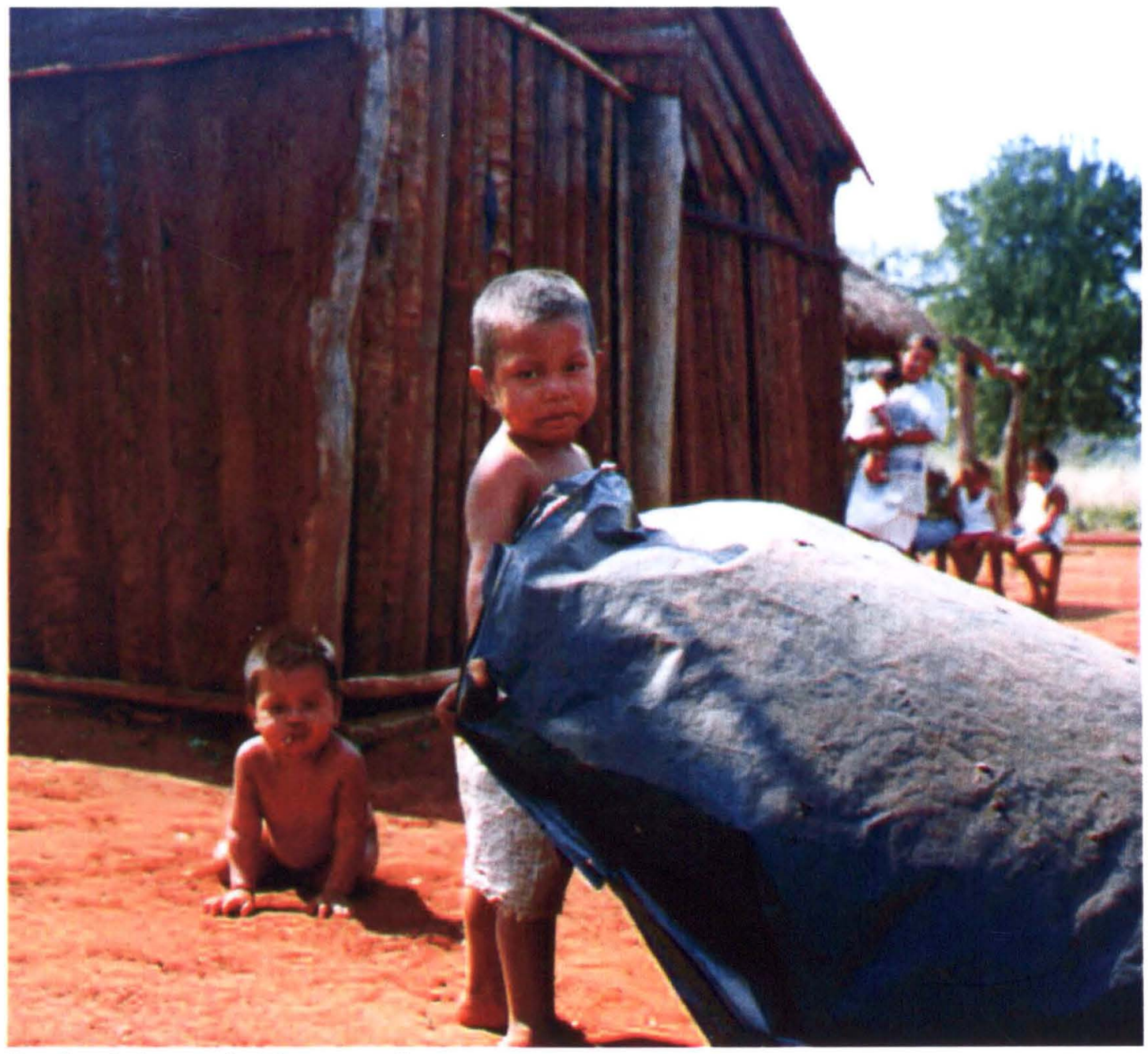

Irmãos brincam de "fazer casa" 


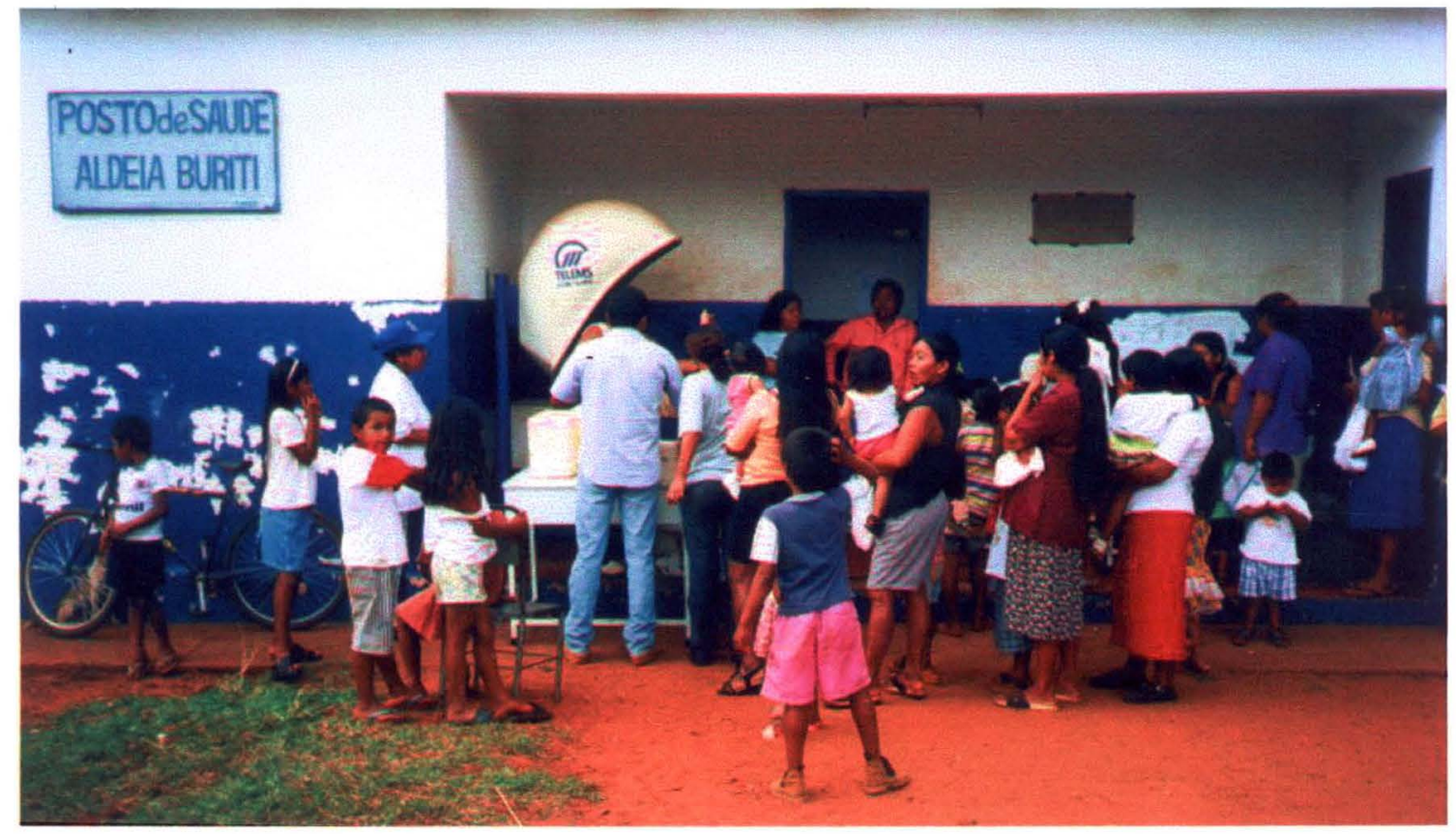

Posto de Saúde Buriti em dia de vacinação 


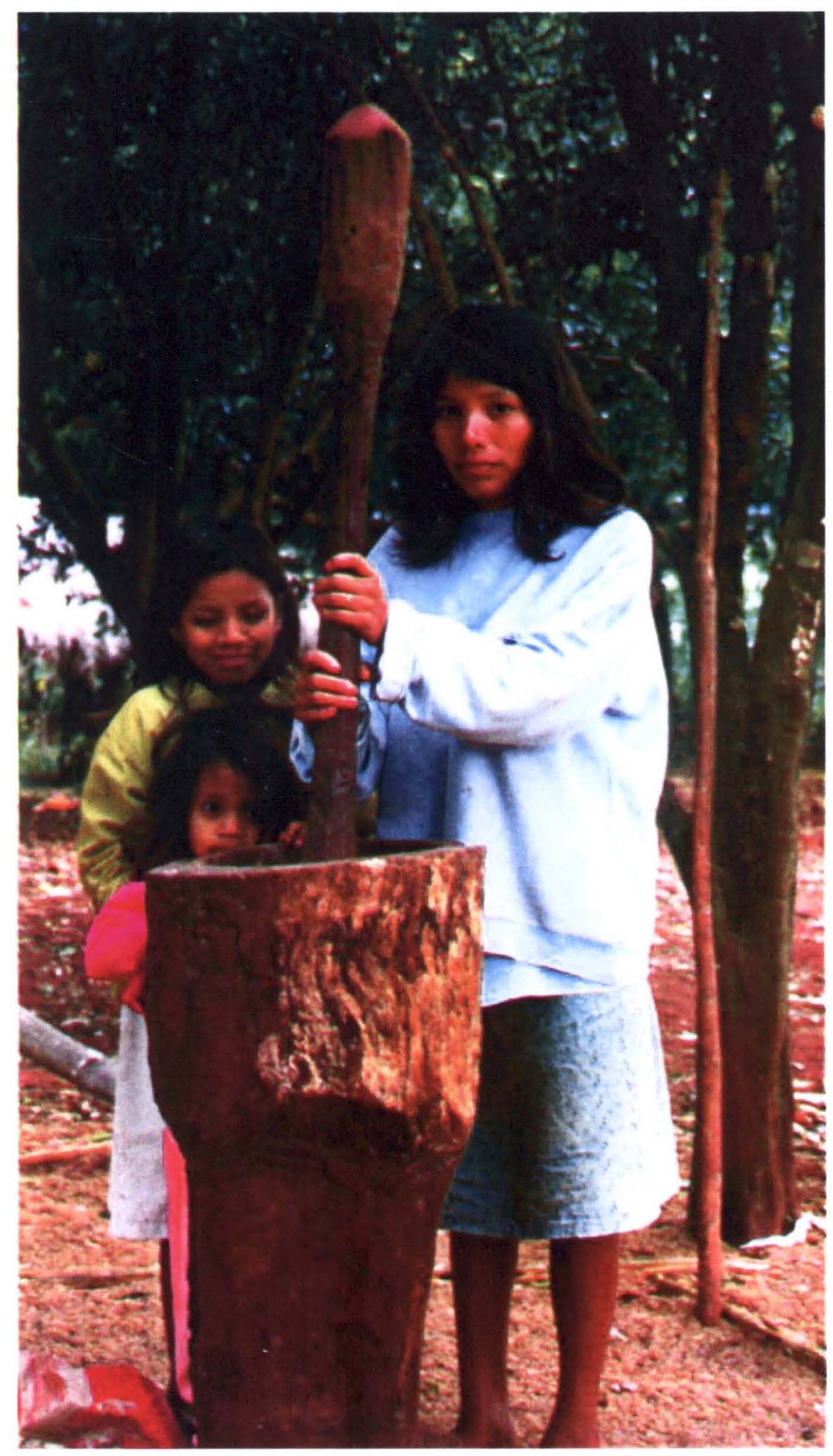

Socando arroz 


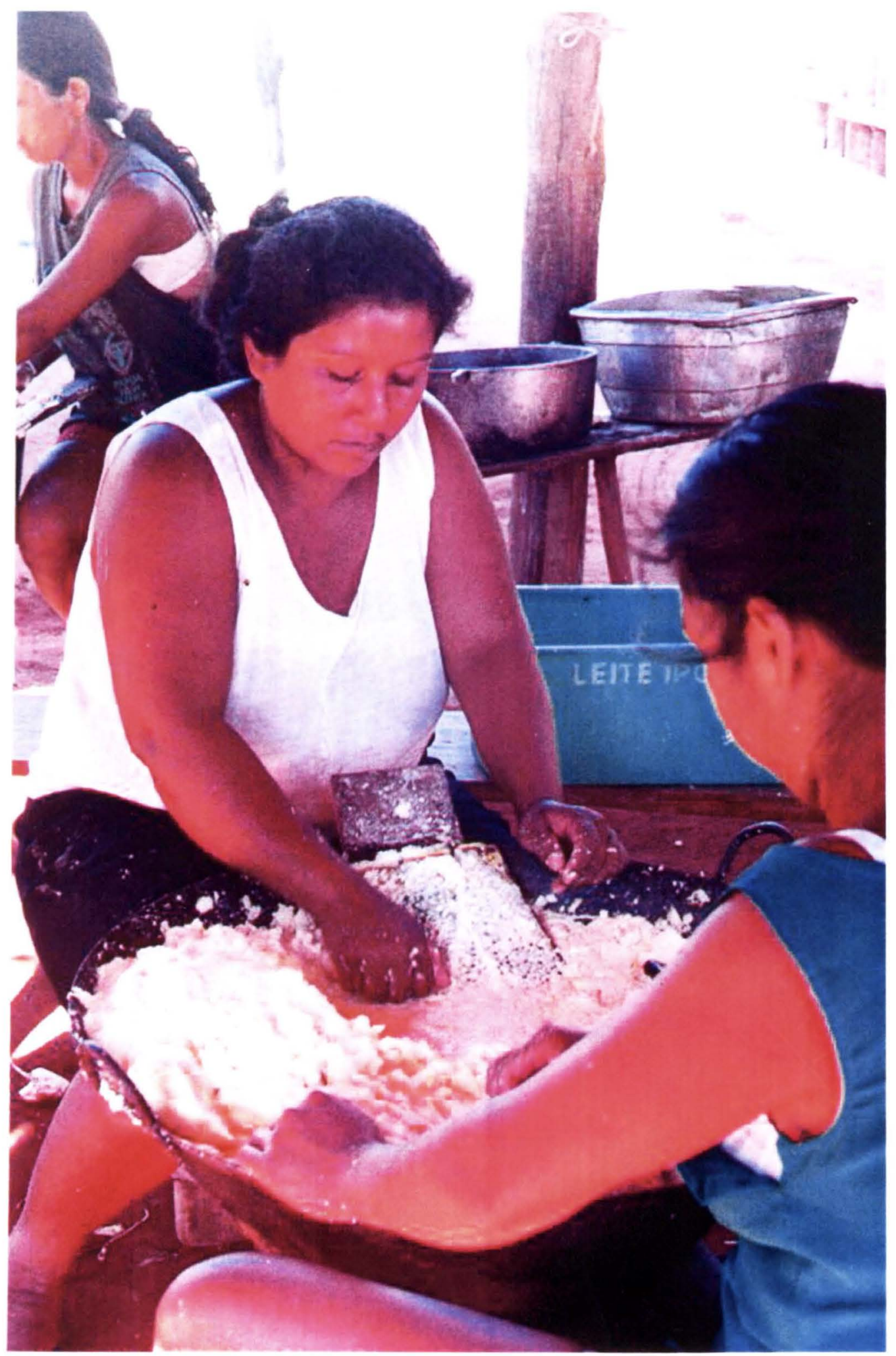

Dia da farinha 

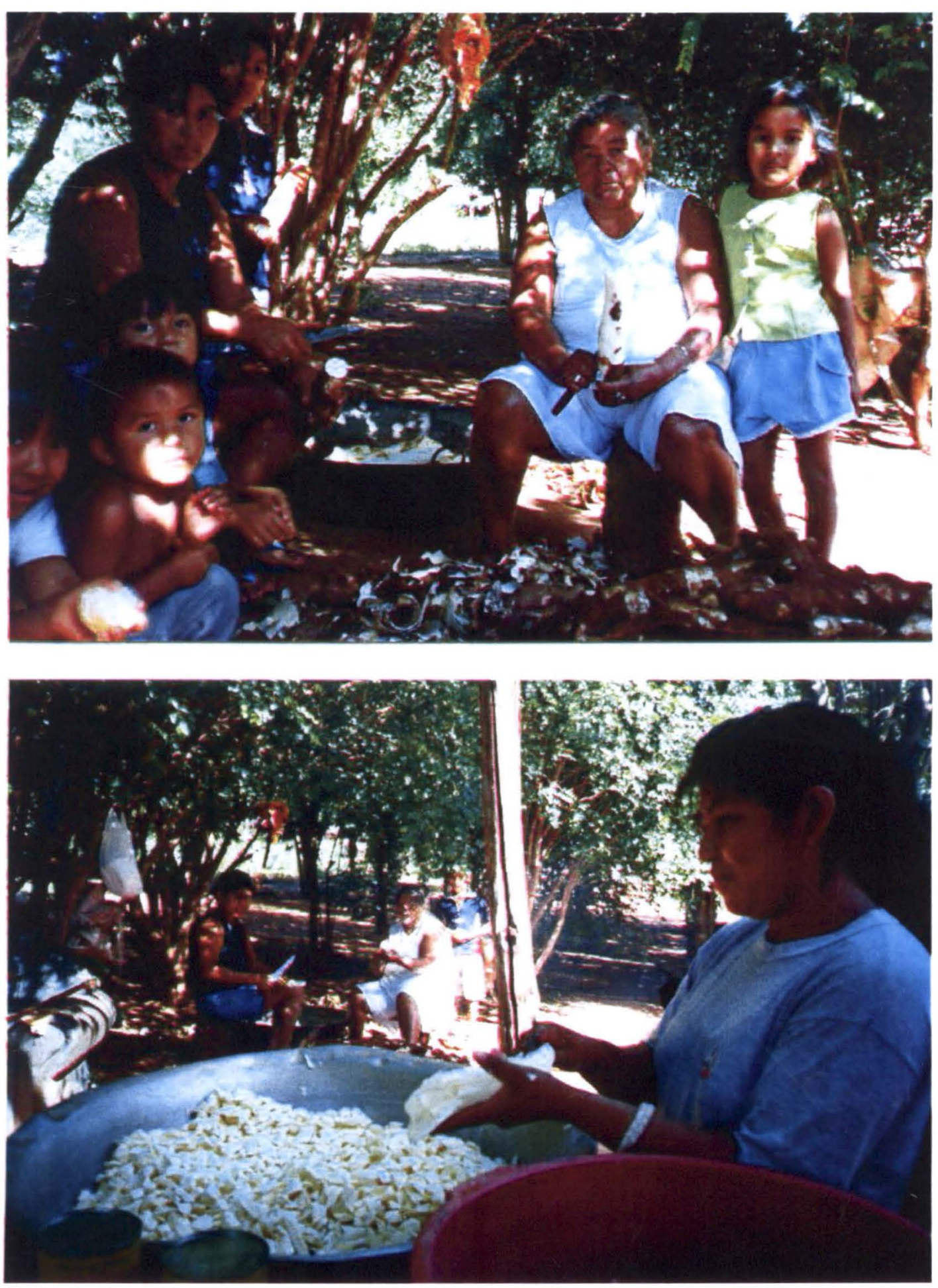

Preparo do puchero 